VILNIAUS GEDIMINO TECHNIKOS UNIVERSITETAS

Grigorij ŽILINSKIJ

\title{
INVESTICIJŲ PORTFELIO SPRENDIMAI
}

DAKTARO DISERTACIJA

SOCIALINIAI MOKSLAI, EKONOMIKA (04S) 
Disertacija rengta 2008-2012 metais Vilniaus Gedimino technikos universitete.

\section{Mokslinis vadovas}

prof. habil. dr. Aleksandras Vytautas RUTKAUSKAS (Vilniaus Gedimino technikos universitetas, socialiniai mokslai, ekonomika-04S).

VGTU leidyklos TECHNIKA 2078-M mokslo literatūros knyga http://leidykla.vgtu.lt

ISBN 978-9955-28-

(C) VGTU leidykla TECHNIKA, 2012

(C) Grigorij Žilinskij, 2012

grigorij.zilinskij@vgtu.lt 
VILNIUS GEDIMINAS TECHNICAL UNIVERSITY

Grigorij ŽILINSKIJ

\section{INVESTMENT PORTFOLIO SOLUTIONS}

DOCTORAL DISSERTATION

SOCIAL SCIENCES,

ECONOMICS (04S)

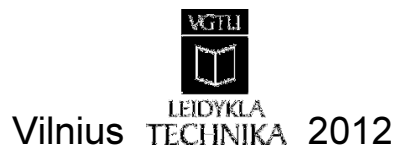


Doctoral dissertation was prepared at Vilnius Gediminas Technical University in 2008-2012.

\section{Scientific Supervisor}

Prof Dr Habil Aleksandras Vytautas RUTKAUSKAS (Vilnius Gediminas

Technical University, Social Sciences, Economics - 04S). 


\section{Reziumè}

Disertacijoje nagrinejama investiciju portfelio sudarymo ir valdymo rinku dinamikos sąlygomis problematika. Globali finansų krizè parodè, kad investuojant atsiranda ne tik uždarbio galimybès, bet ir gana didelè praradimu rizika.

Pagrindinis disertacijos tikslas - pasiūlyti ir empiriškai aprobuoti šiuolaikinių rinkų dinamikos iššūkius atitinkančius investicijų portfelio sudarymo ir valdymo sprendimus skirtingus investavimo polinkius turintiems investuotojams.

Daktaro disertaciją sudaro įvadas, trys skyriai ir bendrosios išvados.

Ivade suformuluojama mokslinè darbo problema, pagrindžiamas jos aktualumas, ivardijamas tyrimo objektas, darbo tikslas ir uždaviniai, pristatoma tyrimo metodika, darbo mokslinis naujumas ir gautų rezultatu praktinė reikšmé, ivardijami ginamieji teiginiai.

Pirmajame skyriuje nagrinejjamos plačiai diversifikuoto investicijų portfelio sudarymo galimybès. İvertinami mokslininkų pasiūlymai dèl skirtingų aktyvų (investicinio turto klasių) itraukimo i investicijų portfelį, sudarytas biržoje prekiaujamų fondu portfelis ir iqvertintas jo efektyvumas. Pasiūlytas investuotojo realiai patirtos rizikos vertinimo metodas.

Antrajame skyriuje detalizuoti aktyvaus investicijuc portfelio valdymo taikant finansini svertą sprendimai. Ivertinti efektyviosios portfelių ribos pokyčiai bei aktyvaus portfelio valdymo taikant finansini svertą tikslingumas. Pasiūlytas prognozavimo tikslumu praeityje paremtas prognoziu integravimo metodas ir įvertintas jo efektyvumas integruojant skirtingo periodo laiko eilučiu prognozes. Pasiūlytas investuotojui priimtina perteklinio laukiamo pelningumo ir patiriamų sąnaudų santyki ịvertinantis sprendimo keisti portfelio sudetị prièmimo metodas. Visi pasiūlymai apibendrinti aktyvaus portfelio valdymo modelyje.

Trečiajame skyriuje atlikta išsami daugiakriterio sprendimų prièmimo metodų taikymo investicijų portfelio sudarymo problemai spręsti galimybių analizè. Pasiūlytas ir patikrintas rinkos sąlygomis akcijų investiciniu patrauklumu paremtas investiciju portfelio sudarymo metodas. Suformuluotos akcijų investiciniu patrauklumu paremto portfelio sprendimų paramos sistemos, užtikrinančios pasiūlyto metodo taikymo galimybių išplètimą, sukūrimo gairès.

Disertacijos pabaigoje suformuluotos bendrosios išvados.

Disertacijos tema paskelbti 6 straipsniai: 2 - recenzuojamuose mokslo žurnaluose, referuojamuose duomenų bazèse, 2 - recenzuojamose tarptautinių konferencijų medžiagose, 2 - jaunujų mokslininkų konferencijų medžiagose. 


\section{Abstract}

The dissertation analyses the topic and problems of selection and management of investment portfolio in terms of market dynamics. The global financial crisis has revealed that investments bear not only return possibilities but also a relatively high risk of loss.

The main aim of the Thesis is to propose and test empirically investment portfolio selection and management solutions matching the tendencies of modern markets for the investors with different investing preferences.

The Doctoral Thesis consists of the introduction, three body chapters and conclusions.

The introduction presents the scientific problem, its relevance, the object of the research, the aim and tasks of the research, methods of research, scientific novelty of the Thesis, practical significance of its results and defended statements.

The first chapter provides analysis of possibilities for a widely diversified investment portfolio selection. The study of proposals of scientists on different assets combining into an investment portfolio is carried out. Portfolio of exchange traded funds is created and its efficiency is evaluated. The method for actually incurred risk evaluation is suggested.

Solutions for active investment portfolio management with financial leverage are specified in the second chapter. The changes of efficient set of portfolios and expediency of active portfolio management with financial leverage are evaluated. Forecasts integration method, based on prediction accuracy in the past, is proposed; its efficiency is evaluated integrating different period time series forecasts. A portfolio rebalancing method, based on investor appropriate excess return and incurred costs ratio evaluation is proposed. All suggestions are summarized in an active portfolio management model.

The third chapter presents a comprehensive analysis of application possibilities of multicriteria decision making methods to deal with efficient portfolio selection problem. Investment portfolio selection method, based on stock investment attractiveness, is proposed and tested in real market conditions. Guidelines for development of the portfolio selection decision support system, based on stock investment attractiveness, are formulated, ensuring expansion of application of the suggested method.

Finally, conclusions and proposals are formulated.

6 articles are published on the theme of the Thesis: 2 in the peer-reviewed scientific journals, 2 articles in the peer-reviewed international conferences materials, 2 articles in conference for young researchers' materials. 


\section{Žymëjimai}

\section{Simboliai}

$E(R p)$ - tikètina portfelio grąža;

$w_{i}$ - investicijų dalis, investuota ị i vertybinị popierių;

$E\left(R_{i}\right)$ - i vertybinio popieriaus tikètinas pelningumas (grąža);

$\operatorname{COV}\left(R_{i} R_{j}\right)$ - kovariacija tarp i ir j finansinių priemonių grąžos;

$E\left(R_{i}\right)^{t}$ - laukiamas pelningumas įvertinus proporcines sandorių sąnaudas;

$X_{t}$ - akcijos grąža t laikotarpiu;

$X_{t^{+}+}$- grąžos prognozè artimiausiam ateities laikotarpiui;

$X_{t+1}^{k}$ - k periodo ilgio prognozé;

$w\left(X_{t+1}^{k}\right)$ - k periodo ilgio prognozės svoris bendrame ịvertyje;

$M S E_{t}^{k}-\mathrm{k}$ periodo ilgio laiko eilutès prognozių vidutinè kvadratinè paklaida;

$C$ - bendrosios sandorių sąnaudos;

$c_{t, i}$ - sandoriu sąnaudos, tenkančios vienam rizikingo aktyvo i vertès vienetui $\mathrm{t}$ laikotarpiu;

$w_{t, i}-\mathrm{t}$ laikotarpiu ị i akciją investuotų lèšu suma; 
$c_{i}^{+}-\mathrm{i}$ aktyvo įsigijimo sandorių sąnaudos;

$c_{i}^{-}-\mathrm{i}$ aktyvo pardavimo sandorių sąnaudos;

$r_{-}-$nerizikingo skolinimo palūkanų norma;

$w_{-}$- lèšos, skolinamos už nerizikingą palūkanų normą;

$r_{+}-$nerizikingo skolinimosi palūkanų norma;

$w_{+}-$lèšų suma, pasiskolinama už nerizikingą palūkanų normą;

$A$ - rizikos tolerancijos lygis;

$W$ - investicijoms skirta investuotojo lèšų suma;

$w_{+}^{\max }-$ maksimali suma, kurią galima pasiskolinti už nerizikingą palūkanų normą;

$w_{-}^{\min }-$ minimali nerizikingų investicijų suma;

$w_{i}^{\min }-$ minimali rizikingų investicijų suma į i akcija;

$K$ - kriterijaus, remiantis kuriuo priimamas sprendimas keisti portfelio sudèti, reikšmè;

$K_{\min }-$ minimali kriterijaus reikšmè, kad būtų priimtas sprendimas keisti portfelio sudètị;

$\triangle E(R)$ - ribinis laukiamo pelningumo pokytis;

$\triangle C$ - ribinès sandorių sąnaudos;

$K_{\min }^{\prime}$ - investuotojo pasirinkta minimali ribinio laukiamo pelningumo pokyčio ir ribinių sąnaudų reikšmè, kad būtų priimtas sprendimas iš dalies keisti portfelio sudètí;

$K_{i}-$ i vertinimo kriterijus;

$\check{z}_{i}-\mathrm{i}$ kriterijaus poveikio kryptis;

$q_{i}-\mathrm{i}$ kriterijaus svoris;

$x_{i j}-\mathrm{j}$ akcijos i kriterijaus reikšme;

$x_{i \min }-$ minimali i kriterijaus reikšmè tarp visų akcijų;

$S_{+j}$ - maksimizuojančių kriterijų reikšmių sumos;

$S_{-j}$ - minimizuojančių kriterijų reikšmių sumos;

$Q_{j}-\mathrm{j}$ akcijos santykinis investicinis patrauklumas;

$\operatorname{corr}_{i j}-\mathrm{i}$ ir j akcijų gražos koreliacijos koeficientas;

$\operatorname{corr}_{p}$ - vidinès portfelio koreliacijos koeficientas;

$Q_{S}$ - sektoriaus investicinis patrauklumas;

$Q_{A}$ - akcijos patrauklumas sektoriaus lygmeniu;

$Q$ - akcijos patrauklumas rinkos mastu;

$Q_{v}$ - virtualios akcijos investicinis patrauklumas. 


\section{Santrumpos}

BPF - biržoje prekiaujami fondai (angl. Exchange traded funds - ETF);

EWC - iShares MSCI Canada Index Fund;

EZA - iShares MSCI South Africa Index Fund;

EPP - iShares MSCI Pacific ex-Japan Index Fund;

ILF - iShares S\&P Latin America 40 Index Fund;

FEZ - Dow Jones EURO STOXX 50 ETF;

SPY - SPDR S\&P 500 ETF;

GUR - SPDR S\&P Emerging Europe ETF;

GAF - SPDR S\&P Emerging Middle East \& Africa ETF;

BSV - Short-Term Bond ETF;

BIV - Inter-Term Bond ETF;

BLV - Long-Term Bond ETF;

FXA - CurrencyShares Australian Dollar Trust ETF;

FXY - CurrencyShares Japanese Yen Trust ETF;

FXC - CurrencyShares Canadian Dollar Trust ETF;

FXB - CurrencyShares British Pound Sterling Trust ETF;

FXE - CurrencyShares Euro Trust ETF;

FXS - CurrencyShares Swedish Krona Trust ETF;

FXM - CurrencyShares Mexican Peso Trust ETF;

UUP - PowerShares DB US Dollar Index Bullish Fund;

GLD - streetTRACKS Gold Shares ETF;

SLV - iShares Silver Trust Fund;

DBB - PowerShares DB Base Metals Fund;

DBE - PowerShares DB Energy Fund;

DBA - PowerShares DB Agriculture Fund;

SNTG - standartinis nuokrypis nuo numatytos tikètinos investicijų grąžos;

CML - kapitalo rinkos tiesè (angl. capital market line);

RFR - nerizikinga palūkanų norma (angl. risk free rate);

$\mathrm{OC}$ - sandorių sąnaudos (angl. operation costs);

APG - APB „Apranga“;

CTS - AB „City service“;

IVL - AB ,Invalda“;

LNA - AB „Linas Agro Group“;

PTR - AB Panevèžio statybos trestas;

$\mathrm{SAB}$ - AB Šiaulių bankas; 
TEO - AB TEO LT;

UKB - AB Ūkio bankas;

SMA - paprastas slankusis vidurkis;

WMA - svertinis slankusis vidurkis;

EMA - eksponentinis slankusis vidurkis;

ARMA - autoregresinis slankusis vidurkis;

ANN - dirbtinis neuroninis tinklas (angl. Artificial neural network);

HMM - paslèptasis Markovo modelis (angl. Hidden Markov Model);

PSO - dalelių masès optimizavimas (angl. Particle Swarm optimisation);

NLICA - nelinijinè nepriklausomų komponentų analizè;

SVR - paramos vektorių regresija;

GBM - geometrinis Browno judejimas;

HCSOM - Hybrid Cohonen Self Organising Map;

MAFE - vidutiné absoliutinè prognozavimo paklaida;

FE - prognozės paklaida;

AFE - absoliuti prognozès paklaida;

MSE - vidutinè kvadratine paklaida;

RMSE - šaknis iš vidutinès kvadratinès paklaidos;

MAPE - vidutinè absoliuti procentinè paklaida;

MAD - vidutinis absoliutus nuokrypis;

TIC - Theil'o nelygybès koeficientas;

RMAE - santykinè vidutinè absoliuti paklaida;

NMSE - normalizuota vidutinè standartinè paklaida;

POCID - krypties pokyčio prognozė;

ARV - vidutinis santykinis neatitikimas;

AA - Alcoa Inc.;

BA - Boeing Company;

CAT - Caterpillar, Inc.;

DD - E. I. du Pont de Nemours and Company;

GE - General Electric Company;

IBM - International Business Machines;

KO - Coca-Cola Company;

EUR - euras;

USD - JAV doleris;

CHF - Šveicarijos frankas;

GBP - Didžiosios Britanijos svaras; 
JPY - Japonijos jena;

APV - aktyvus portfelio valdymas;

SV - pusiau variacija;

MCDM - daugiakriteris sprendimų prièmimas;

MADM - daugelį veiksnių įvertinantis sprendimų prièmimas;

MODM - daugiatikslis sprendimų prièmimas;

CVX - Chevron Corporation;

INTC - Intel Corporation;

JNJ - Johnson \& Johnson;

MCD - McDonald's Corporation;

MMM - 3M Company;

MRK - Merck \& Company, Inc.;

PFE - Pfizer, Inc.;

$\mathrm{T}-\mathrm{AT} \& \mathrm{~T}$ Inc.;

UTX - United Technologies Corporation;

VZ - Verizon Communications Inc.;

XOM - Exxon Mobil Corporation. 


\section{Turinys}

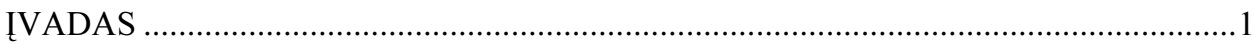

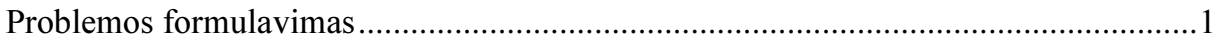

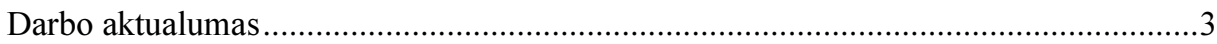

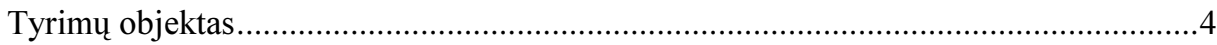

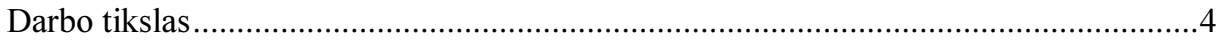

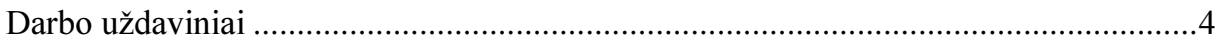

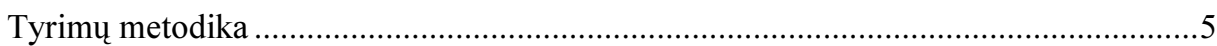

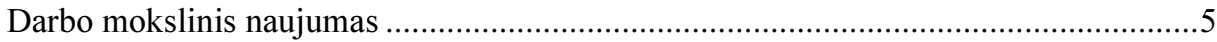

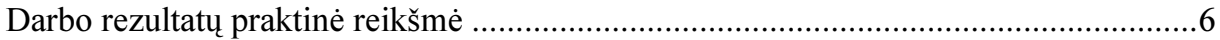

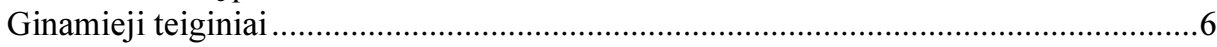

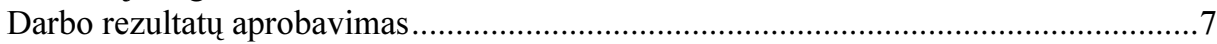

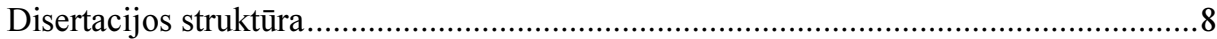

1. PASYVAUS INVESTUOTOJO APSISAUGOJIMO NUO RIZIKOS GALIMYBIU

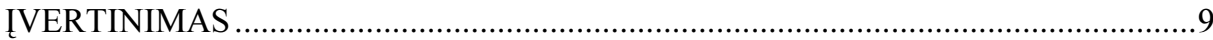

1.1. Mokslininkų siūlomi portfelio diversifikavimo sprendimai ..................................10

1.2. Investicinių priemonių pasirinkimas, jų charakteristikų vertinimas .......................15

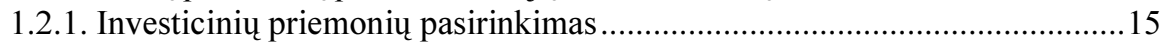

1.2.2. Atrinktų BPF pagrindinių charakteristikų vertinimas .................................. 18

1.3. Plačiai diversifikuoto portfelio sudarymas ir jo rezultatu ịvertinimas ....................23

1.3.1.Plačiai diversifikuoto portfelio sudarymas ................................................23

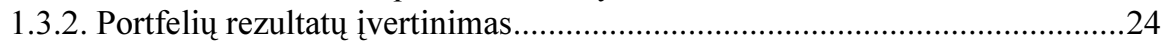


2. PORTFELIO SPRENDIMAI AKTYVIEMS INVESTUOTOJAMS .......................29

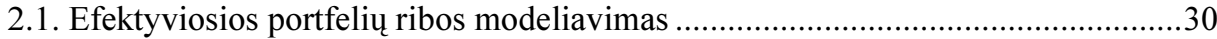

2.1.1. Mokslinių darbų efektyviosios ribos modeliavimo tematika analizè...........30

2.1.2. Efektyviosios portfelių ribos modeliavimas aktyviai valdant investicijų

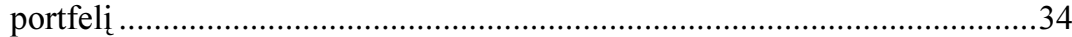

2.1.3. Aktyvaus portfelio valdymo taikant finansini svertą tikslingumo empirinis tyrimas

2.2. Prognozavimo tikslumo didinimas integruojant skirtingais metodais gautas

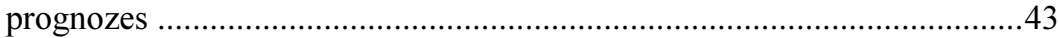

2.2.1. Laukiamo pelningumo įvertinimo problemos ištirtumo lygis.....................44

2.2.2. Prognozių integravimo metodo sukūrimas ..........................................47

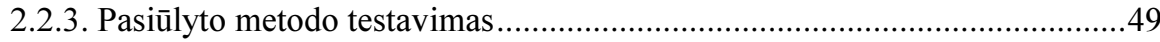

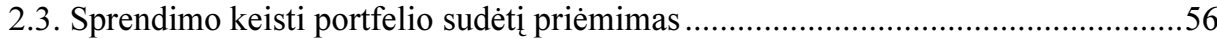

2.3.1. Problemos ištirtumo lygis kitų mokslininkų darbuose ............................56

2.3.2. Siūlomas sprendimo keisti portfelio sudeti prièmimo metodas ..................58

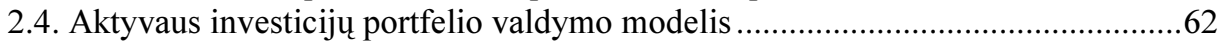

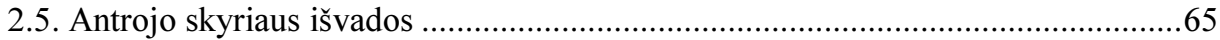

3. AKCIJU INVESTICINIU PATRAUKLUMU PAREMTAS INVESTICIJŲ PORTFELIS

3.1. Daugiakriterio sprendimų prièmimo metodų ivvairovė ir jų taikymo investicijų portfeliui sudaryti galimybės ..................................................... 68

3.2. Bazinio akcijų investiciniu patrauklumu paremto portfelio optimizavimo modelio

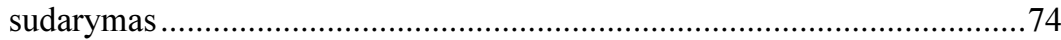

3.3. Sprendimų detalizavimas ir modelio testavimas ............................................. 76

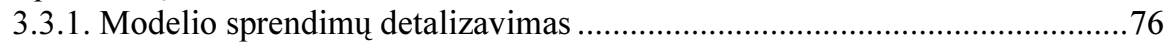

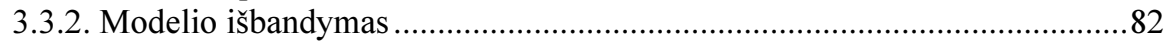

3.4. Akcijų investiciniu patrauklumu paremto portfelio sprendimų paramos sistemos

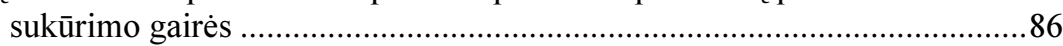

3.4.1. Duomenu patikimumo ir surinkimo operatyvumo užtikrinimas .................87

3.4.2. Duomenų apdorojimo galimybès .........................................................88

3.4.3. Sprendimu prièmimas ir monitoringas............................................... 90

3.4.4. Principinė sprendimų paramos sistemos veikimo schema ........................91

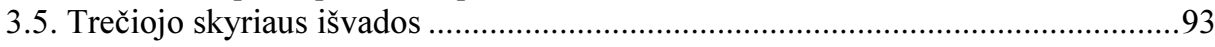

BENDROSIOS IŠVADOS _............................................................................ 95

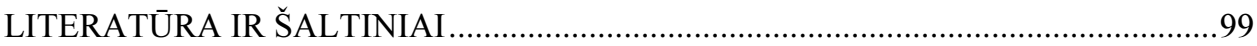

AUTORIAUS PUBLIKACIJŲ DISERTACIJOS TEMA SĄRAŠAS ......................... 115

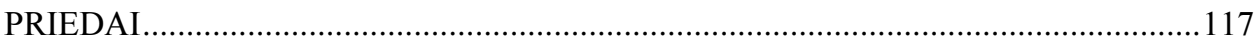

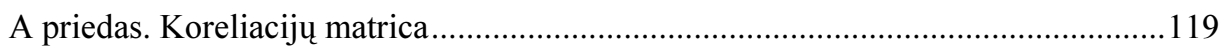


B priedas. Aktyvų deriniai portfeliuose

C priedas. Portfelių verčių kitimas 2007-04-10-2011-02-10 laikotarpiu

D priedas. Kasdieniai portfelių verčių svyravimai 2011-02-10-2012-04-10 laikotarpiu

E priedas. Portfeliu pelningumas ir rizika

F priedas. Vidutinès kvadratinès indeksu/akcijų grąžos prognozavimo paklaidos .....124

$\mathrm{G}$ priedas. Akcijų investiciniam patrauklumui (sprendimui dèl investavimo 2003-04-01-2004-04-01 laikotarpiui priimti) nustatyti taikytos kriteriju reikšmès

$\mathrm{H}$ priedas. Akcijų investiciniam patrauklumui (sprendimui dèl investavimo 2004-04-01-2005-04-01 laikotarpiui priimti) nustatyti taikytos kriteriju reikšmès

I priedas. Akcijų investiciniam patrauklumui (sprendimui dèl investavimo 2005-04-01-2006-04-01 laikotarpiui priimti) nustatyti taikytos kriteriju reikšmès

$\mathrm{J}$ priedas. Akcijų investiciniam patrauklumui (sprendimui dèl investavimo 2006-04-01-2007-04-01 laikotarpiui priimti) nustatyti taikytos kriteriju reikšmès

$\mathrm{K}$ priedas. Akcijų investiciniam patrauklumui (sprendimui dèl investavimo 2007-04-01-2008-04-01 laikotarpiui priimti) nustatyti taikytos kriteriju reikšmès

L priedas. Akcijų investiciniam patrauklumui (sprendimui dèl investavimo 2008-04-01-2009-04-01 laikotarpiui priimti) nustatyti taikytos kriteriju reikšmès

M priedas. Akcijų investiciniam patrauklumui (sprendimui dèl investavimo 2009-04-01-2010-04-01 laikotarpiui priimti) nustatyti taikytos kriteriju reikšmès

$\mathrm{N}$ priedas. Akcijų investiciniam patrauklumui (sprendimui dèl investavimo 2010-04-01-2011-04-01 laikotarpiui priimti) nustatyti taikytos kriteriju reikšmès

O priedas. Akcijų investiciniam patrauklumui (sprendimui dèl investavimo 2011-04-01-2012-04-01 laikotarpiui priimti) nustatyti taikytos kriteriju reikšmès

P priedas. Optimalios portfelių sudètys 


\section{Contents}

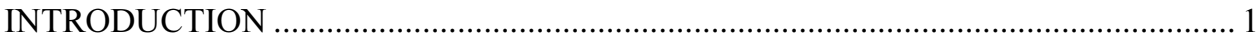

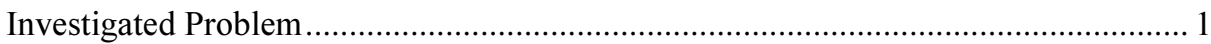

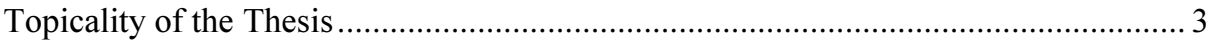

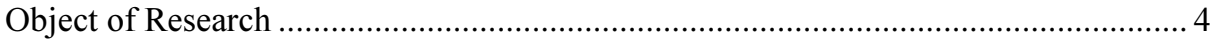

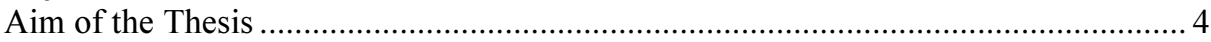

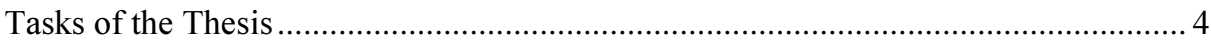

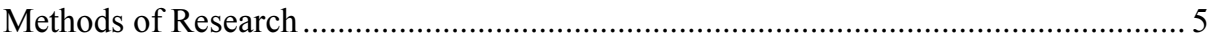

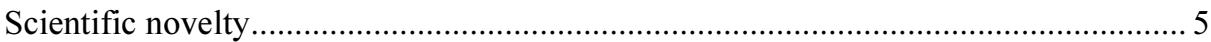

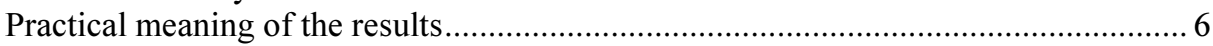

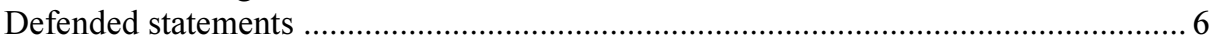

Approval of the results ..................................................................................... 7

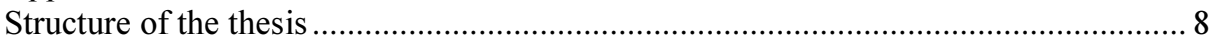

1. EVALUATION OF PASSIVE INVESTOR'S RISK HEDGING POSSIBILITIES..... 9

1.1. Researchers' propositions for portfolio diversification....................................... 10

1.2. Selection of investment objects and evaluation of their characteristics ............... 15

1.2.1. Selection of investment objects ……………......................................... 15

1.2.2. Evaluation of the main characteristics of selected ETFs …….................... 18

1.3. Selection of a widely diversified portfolio and evaluation of its results ............. 23

1.3.1. Selection of a widely diversified portfolio ................................................23

1.3.2. Evaluation of the results of selected portfolios........................................... 24

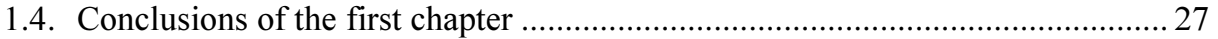




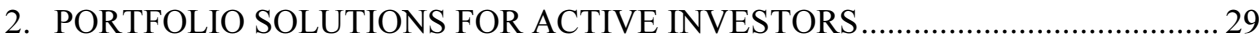

2.1. Modelling of the efficient set of portfolios ..................................................... 30

2.1.1. Analysis of scientific works on the topic of modelling of efficient set ...... 30

2.1.2. Modelling of efficient set of portfolios....................................................... 34

2.1.3. Empirical analysis of expediency of active portfolio management with

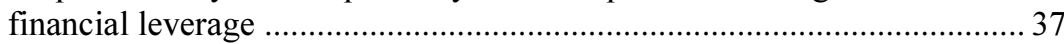

2.2. Improvement of prediction accuracy by integrating forecasts obtained using several forecasting methods ................................................................................. 43

2.2.1. The level of exploration of expected return evaluation problem ................. 44

2.2.2. Development of the method of forecasts integration ................................... 47

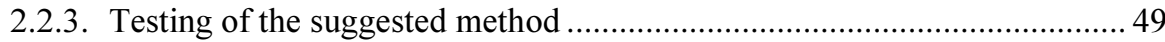

2.3. Portfolio rebalancing decision making............................................................56

2.3.1. The level of exploration of the problem in scientific literature ..................56

2.3.2. The suggested portfolio rebalancing decision making method.....................59

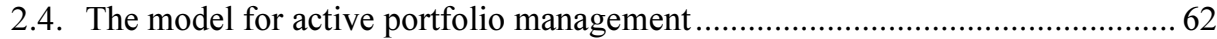

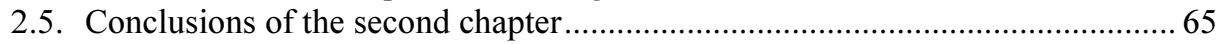

3. INVESTMENT PORTFOLIO BASED ON STOCK INVESTMENT

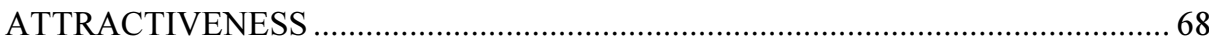

3.1. The variety of multicriteria decision making methods and their application possibilities in portfolio selection

3.2. Development of the basic model for investment portfolio optimization based on

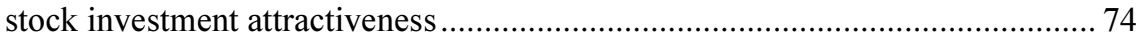

3.3. Specification of solutions and testing of the model .......................................... 76

3.3.1. Specification of the model solutions …………....................................... 76

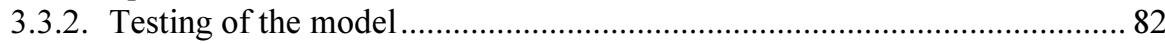

3.4. Guidelines for creation portfolio selection decision support system, based on

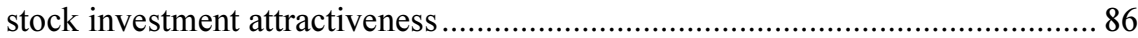

3.4.1. Ensuring data reliability and timeliness of its collection ...........................8 87

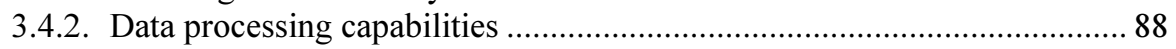

3.4.3. Decision making and monitoring ......................................................... 90

3.4.4. The principal operating scheme of decision support system ..................... 91

3.5. Conclusions of the third chapter .................................................................... 93

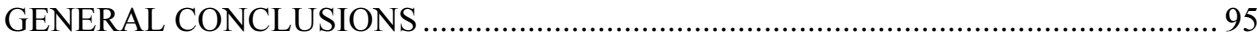

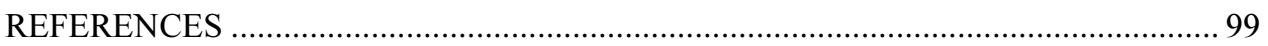

AUTHOR'S PUBLICATIONS ON THE TOPIC OF THE THESIS ….......................... 115

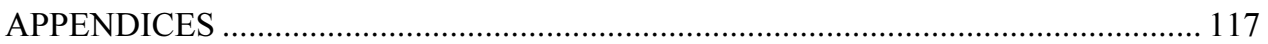

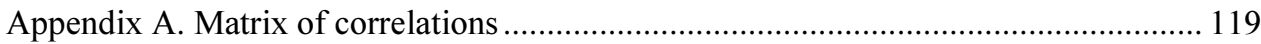

Appendix B. Combinations of actives in portfolios ...................................................... 120

Appendix C. Portfolios' value changes in period 2007-04-10-2011-02-10 .................. 121

Appendix D. Daily fluctuations of portfolio values in period 2011-02-10-2012-04-10. 122

Appendix E. Risk and return of portfolios ................................................................... 123 
Appendix F. Mean square index/share return forecasting errors 124

Appendix G. Values of criterions used to evaluate stocks' investment attractiveness for 2003-04-01-2004-04-01 investment period

Appendix H. Values of criterions used to evaluate stocks' investment attractiveness for 2004-04-01-2005-04-01 investment period

Appendix I. Values of criterions used to evaluate stocks' investment attractiveness for 2005-04-01-2006-04-01 investment period

Appendix J. Values of criterions used to evaluate stocks' investment attractiveness for 2006-04-01-2007-04-01 investment period

Appendix K. Values of criterions used to evaluate stocks' investment attractiveness for 2007-04-01-2008-04-01 investment period

Appendix L. Values of criterions used to evaluate stocks' investment attractiveness for 2008-04-01-2009-04-01 investment period

Appendix M. Values of criterions used to evaluate stocks' investment attractiveness for 2009-04-01-2010-04-01 investment period

Appendix N. Values of criterions used to evaluate stocks' investment attractiveness for 2010-04-01-2011-04-01 investment period

Appendix O. Values of criterions used to evaluate stocks' investment attractiveness for 2011-04-01-2012-04-01 investment period

Appendix P. Optimal compositions of portfolios 



\section{Ivadas}

\section{Problemos formulavimas}

Investicijų portfelio sudarymo ir valdymo proceso analize bei jo tobulinimo galimybių paieška yra svarbi šiuolaikinio ekonomikos mokslo plètojimo kryptis. Šios krypties svarbą taip pat pagrindžia investicijų portfelio sudarymo, finansų rinkų efektyvumo ir glaudžiai susijusią tematiką nagrinejjančių mokslininkų gautų Nobelio premijų už pasiekimus ekonomikos moksle skaičius.

Sparti finansų rinkų plètra nulemia naujus iššūkius tiek investuotojams, tiek investavimo problematiką nagrinèjantiems mokslininkams. Iškyla būtinybė sukurti inovatyvius, šiuolaikinèms finansų rinkų salygoms adekvačius teorinius, koncepcinius ir pragmatinius investicijuc portfelio sudarymo ir valdymo sprendimus. Tai, kad mokslininkų siūlomi sprendimai nepakankamai atitinka šios dienos poreikius, liudija po globalios finansų krizès žymių ekonomistų išsakyti raginimai daliai Nobelio premijos laureatų atsisakyti gautų premijų.

Ivertinus pasirinktos tematikos aktualuma, disertacijoje nagrinejama ir sprendžiama problema formuluojama kaip šiuolaikinejje ekonomikos teorijoje ir praktikoje sukaupto mokslinio pažinimo bei siūlomų sprendimų nepakankamas adekvatumas siekiant užtikrinti efektyvų investicijų portfelio - kaip dominuojančios investavimo strategijos - sudarymą ir valdymą skirtingus investavimo būdus pasirenkantiems investuotojams esant šiuolaikinėms finansų 
rinkoms būdingoms tendencijoms ir iššūkiams, tokiems kaip didejjanti rinkų dinamika, sudètingejjanti jų plètros galimybių ìvairovè ir investavimo sprendimų sistemiškumo poreikis.

Siekiant geriau atskleisti disertacijoje nagrinejjamos problemos esmę, tikslinga išgryninti pagrindinius probleminius jos aspektus:

- mokslinèje literatūroje nepakankamai įvertintos skirtingų aktyvų (turto klasių) derinimo investicijų portfelyje galimybès, kurios galètų leisti sumažinti investicijų portfelio riziką ir galimus netekimus smunkant atskiroms rinkoms;

- nepakankamas realios rinkos apribojimų ir portfelio valdymo sąnaudų ivertinimas moderniojoje portfelio teorijoje gali klaidinti investuotojus suteikdamas perteklinių lūkesčių dèl portfelio laukiamos grąžos, ypač aktyviai valdant portfeli taikant finansinį sverta;

- nepakankamai išnagrinètos skirtingais metodais gautų akcijų kainų (grąžos) prognoziu integravimo galimybės, kurios leistų sumažinti galimas užprogramuotas atskirų prognozavimo metodų klaidas (pvz., esant „techniniams atšokimams" ar akcijų rinkoms atsigaunant po krizės) ir padidinti prognozavimo tikslumą;

- nèra pasiūlyta metodų, ivvertinančių investuotojui priimtiną laukiamo pelningumo pokyčio ir realiai patiriamų sąnaudų santyki priimant sprendimus dèl portfelio sudèties keitimo;

- moksliniuose darbuose portfeli optimizuoti siūloma remiantis pelningumu ir rizika, kurie dažniausiai nustatomi remiantis praeities grąžos analize, kartais itraukiant papildomas charakteristikas (pvz., likviduma, diversifikacijos lygi ir pan.), tačiau nèra pasiūlyto modelio ar sistemos, kurie leistų optimizuojant portfeli siekti maksimizuoti bendrą investicijų portfelio patraukluma, ivertinanti kokybinius ir kiekybinius, fundamentaliosios ir techninès analizès veiksnius, konkrečiam investuotojui.

Atsižvelgiant $i$ ivardintą problemą ir pagrindinius jos aspektus tikslinga išnagrinèti ir pasiūlyti konkrečius portfelio valdymo sprendimus skirtingus investavimo polinkius turintiems investuotojams - i̇vertinti pasyvių investuotojų apsisaugojimo nuo rizikos ir netekčių padidejusio rinkų nepastovumo laikotarpiais galimybes, apribojimu ir sąnaudu poveiki efektyviajai portfeliu ribai, sukurti prognoziu integravimo ir sprendimo keisti portfelio sudèti prièmimo metodus, pasiūlyti akcijų investiciniu patrauklumu paremtą investicijų portfelio sudarymo modeli ir detalizuoti jo pagrindu galimos sukurti sprendimu paramos sistemos gaires. 


\section{Darbo aktualumas}

Sparti finansų rinkų plètra, investicinių priemonių ir paslaugų ivairovès didejimas - efektyvių investavimo sprendimų sudetingumo ir naujų investavimo galimybiu irodymas. Naujos investiciju portfelio diversifikavimo galimybès taip pat iškelia naujus iššūkius, kurie reikalauja vis pažangesnių mokslinių ir praktinių sprendimų. Globali finansų krizè parodè, kad tradiciniai portfelio diversifikavimo būdai įsigyjant skirtingų sektorių ar skirtingų regionų i̇monių akcijas nèra efektyvūs, kai finansų rinkos yra veikiamos sisteminio pobūdžio veiksnių. Šiuolaikinėms finansų rinkoms būdinga dinamika reikalauja adekvačių investicijų valdytojų sprendimų, tačiau net deleguotas, profesionalus investicijų valdymas (pvz. investicinių fondų vienetu issigijimas) krizès laikotarpiu taip pat neapsaugojo investuotojų nuo investicijų vertès sumažèjimo. Iškyla būtinybè ieškoti naujų portfelio sudarymo ir valdymo būdu̧, leidžiančių sumažinti investicijų riziką ir galimus nuostolius padidejusio rinkų nepastovumo laikotarpiu.

Didejanti investicinių priemonių ivvairovè leidžia net privatiems investuotojams investuoti ir viename portfelyje derinti tokias skirtingas turto klases kaip akcijos, skolos vertybiniai popieriai, valiutos ar prekès, kurių kainu pokyčiai tarpusavyje yra mažai ar net neigiamai koreliuoti. Tai sukuria sąlygas plačiai diversifikuotam portfeliui, kuris šiame darbe suvokiamas kaip kryptingai atrinktų aktyvų, o ne visų prieinamų aktyvų rinkinys, sudaryti, bet reikalauja išsamesnès plačiai diversifikuoto portfelio sudarymo galimybių analizès ir jo suteikiamų apsisaugojimo nuo rizikos ir netekčių galimybių vertinimo.

Nepastovumas ir gana dideli kainų svyravimai akcijų rinkoje atveria didesnio uždarbio galimybes aktyviems (dažnai portfelio sudèti keičiantiems) investuotojams. Galimą pelningumą dar labiau padidinti gali finansinio sverto naudojimas, kai tikètino rinkų smukimo laikotarpiais daromos tik nerizikingos investicijos, o laukiamo rinkų kilimo laikotarpiais papildomai yra pasiskolinama siekiant daugiau investuoti $i$ rizikingesnius ir potencialiai pelningesnius vertybinius popierius. Aktyvus investavimas taip pat užtikrina investuotojo tobulejjimą nuolat ieškant naujų sprendimų, kaip išnaudoti rinkos dinamikos galimybes. Tačiau aktyvus portfelio valdymas taikant finansini svertą turi apribojimų, atsiranda papildomų sąnaudų, todèl gali būti pelningas tik tuo atveju, jei bus pasiūlyti efektyvūs sprendimai, kaip igyvendinti konkrečius aktyvaus portfelio valdymo etapus.

Sprogęs nekilnojamojo turto kainų burbulas, ekonomistų nuomonè dèl galimo socialinių tinklų imonių akcijų kainų burbulo formavimosi verčia suabejoti praeities laikotarpių grąžos analizès tinkamumu vertinant laukiamą investicijų grąžă, todèl sprendimai dèl investavimo turètų būti priimami siekiant maksimizuoti bendrą investicijų portfelio atitikti investuotojo poreikiams 
(investicini patraukluma). O didejjantis investuotojų dėmesys i̇monių socialinei atsakomybei reikalauja numatyti galimybę itraukti socialinius, etinius ir kitus kokybinius veiksnius $\mathfrak{i}$ investicinio patrauklumo vertinimą. Bendro investicinio patrauklumo kriterijaus pagrindu sudaromas investicijų portfelis gali užtikrinti ne tik investicijų atitiktị investuotojo poreikiams bet ir darnią verslo, rinkų ir šaliu plètrą.

Apibendrinant pažymètina, kad darbo aktualumas yra grindžiamas būtinybe pasiūlyti portfelio sudarymo ir valdymo sprendimus, leidžiančius maksimizuoti investicijų atitikti investuotojo poreikiams, padidinti grąžą rinkų augimo laikotarpiu ir sumažinti investicijų vertès sumažèjimo riziką rinkų smukimo laikotarpiu.

\section{Tyrimų objektas}

Darbo mokslinių tyrimų objektas - investicijų portfelio sudarymas ir valdymas.

\section{Darbo tikslas}

Pagrindinis disertacijos tikslas - pasiūlyti ir empiriškai aprobuoti šiuolaikinių rinkų tendencijas atitinkančius investicijų portfelio sudarymo ir valdymo sprendimus skirtingus investavimo polinkius turintiems investuotojams.

\section{Darbo uždaviniai}

Darbo tikslui pasiekti yra keliami šie uždaviniai:

1. Išanalizuoti skirtingų aktyvų itraukimo i plačiai diversifikuotą portfeli galimybes ir įvertinti plačiai diversifikuoto portfelio, kaip rizikos mažinimo ir apsisaugojimo nuo atskirų rinkų smukimo priemonès, efektyvuma.

2. Pasiūlyti konkrečius aktyvaus portfelio valdymo taikant finansinị svertą sprendimus:

- ivertinti aktyvaus portfelio valdymo taikant finansini svertą apribojimų ir sąnaudų poveikį efektyviajai portfelių ribai;

- pasiūlyti ir empiriškai aprobuoti atskirų prognozių integravimo metoda;

- pasiūlyti sprendimo keisti portfelio sudèti prièmimo metodą; 
- apibendrinti pateiktus pasiūlymus sukuriant bendrą aktyvaus portfelio valdymo taikant finansinį svertą modeli.

3. Ivertinti daugiakriterio sprendimų prièmimo metodų taikymo investiciju portfeliui sudaryti galimybes, pasiūlyti ir empiriškai aprobuoti akcijų investiciniu patrauklumu paremtą investicijų portfelio sudarymo modeli.

4. Suformuluoti akcijų investiciniu patrauklumu paremto investicijų portfelio sudarymo sprendimų paramos sistemos sukūrimo gaires.

\section{Tyrimų metodika}

Disertacijos tikslui ir keliamiems uždaviniams pasiekti darbe buvo taikoma: literatūros analizei - mokslinių šaltinių analizè, sintezè ir apibendrinimas; teoriniams sprendimams pagristi ir juos aprobuoti - hipotetinis modeliavimas, grafinis vaizdavimas ir lyginimas, daugiakriteris vertinimas, kiekybiniai matematiniai ir statistiniai tyrimo metodai.

\section{Darbo mokslinis naujumas}

Rengiant disertaciją buvo gauti šie ekonomikos mokslui nauji rezultatai:

1. Ivertintos plačiai diversifikuoto portfelio, apimančio akcijų, obligacijų, valiutu ir prekių turto klases, sudarymo galimybès ir efektyvumas rinkų dinamikos sąlygomis. Gauti rezultatai parodè, kad derinti skirtingas turto klases gali būti naudinga mažinant portfelio riziką, tačiau ilgesni laiką nekeičiant portfelio sudèties jo grąža sumažeja.

2. Pasiūlytas investuotojo faktiškai patirtos rizikos vertinimo metodas pagrisstas realios grąžos neatitikimo investuotojo lūkesčiams vertinimu.

3. Ivertinti efektyviosios portfelių ribos pokyčiai aktyviai valdant investiciju portfeli taikant finansini sverta. Rezultatai parodè, kad aktyvus portfelio valdymas taikant finansini svertą gali būti naudingas tik tuo atveju, kai aktyviai naudojamasi nerizikingo skolinimo/skolinimosi galimybėmis.

4. Pasiūlytas prognozių integravimo metodas, leidžiantis tiksliau prognozuoti akciju grąžą ir valiutų kursų pokyčius. Tyrimo rezultatai parodè, jog integruojant skirtingo periodo laiko eilučių paprastojo ir svertinio slankiojo vidurkio metodais gautas prognozes galima sumažinti 
vidutines absoliučias prognozavimo paklaidas, lyginant su tiksliausia iš neintegruotų prognozių vidutiniškai apie 11 proc.

5. Pasiūlytas sprendimo keisti portfelio sudèti, atsižvelgiant į investuotojui priimtiną laukiamos grąžos pokyčio ir realiai patiriamų sąnaudų santyki, prièmimo metodas. Numatyta galimybe keisti portfelio sudèti iš dalies ivertinant ribinį laukiamo pelningumo pokytị ir ribines sąnaudas.

6. Atskleistos daugiakriterio sprendimų prièmimo metodų taikymo akcijų investiciniam patrauklumui nustatyti galimybès ir pasiūlytas akcijų investiciniu patrauklumu paremtas investiciju portfelio sudarymo modelis leidžia, ivvertinus akcijų prekybos, fundamentaliuosius ir net kokybinius rodiklius, i portfeli atrinkti geriausiai investuotojo poreikius atitinkančias akcijas. Suformuluotos gairès akcijų investiciniu patrauklumu paremto portfelio sudarymo sprendimų paramos sistemai sukurti.

\section{Darbo rezultatų praktinẻ reikšmè}

Rengiant disertaciją buvo pasiūlyti konkretūs investicijų portfelio sudarymo ir valdymo sprendimai, kurie gali būti pritaikyti realiomis rinkos sąlygomis, sudarant ir valdant investicijų portfelius. Plačiai diversifikuoto portfelio sudarymo galimybių ịvertinimas gali būti naudingas pasirenkant investicinio turto klases, sprendžiant dèl portfelio sudèties peržiūros periodiškumo, patikslinta efektyvioji portfelių riba - priimant sprendimus dèl aktyvaus portfelio valdymo ir finansinio sverto naudojimo, prognoziu integravimo ir sprendimo keisti portfelio sudèti prièmimo metodai gali būti naudojami sprendimų paramos sistemoms kurti ar tiesiogiai taikomi portfeliui valdyti, darbe suformuluotu gairiu pagrindu gali būti sukurta reali akcijų investiciniu patrauklumu paremto portfelio sudarymo sprendimų paramos sistema.

\section{Ginamieji teiginiai}

1. Skirtingu turto klasių derinimas investicijų portfelyje leidžia sumažinti sisteminę investavimo i vieną turto klasę (pvz., akcijas) rizika, tačiau, atsižvelgiant i tai, jog tiek grą̌̌a, tiek grąžos tarpusavio koreliacijos kinta laike, net plačiai diversifikuoto portfelio sudèti tikslinga periodiškai peržiūrèti.

2. Aktyvus portfelio valdymas taikant finansini svertą gali būti naudingas tik tuo atveju, kai akcijų kainų svyravimai pakankamai dideli, kad 
užtikrintų intensyvų nerizikingo skolinimo/skolinimosi galimybių naudojimą.

3. Atskiri prognozavimo metodai gali turèti užprogramuotų klaidų, todèl siekiant tiksliau prognozuoti tikslinga integruoti skirtingais metodais gautas prognozes, tam galètų būti taikomas disertacijoje pasiūlytas metodas.

4. Vien sandorių sąnaudų eliminavimu paremti sprendimo keisti portfelio sudèti prièmimo metodai negali užtikrinti geriausiai investuotojo poreikius atitinkančių sprendimų, todèl sprendimus tikslinga priimti remiantis laukiamo pelningumo pokyčio ir realiai patiriamų sąnaudų santykiu.

5. Portfelio valdymas remiantis praeities grąžos analize nèra tinkamas investuotojo poreikius atitinkančiam investicijų portfeliui sudaryti ir turi būti paremtas investicinio patrauklumo maksimizavimu konkrečiam investuotojui.

6. Akcijuc investicinio patrauklumo vertinimas yra gana sudètingas, kompleksinis, daug laiko ir duomenų reikalaujantis procesas, todèl akcijų investiciniu patrauklumu paremto portfelio koncepcijos taikymas turi būti sistemizuotas pagal disertacijoje pateiktas gaires.

\section{Darbo rezultatų aprobavimas}

Disertacijos tema yra išspausdinti 6 moksliniai straipsniai: du - recenzuojamame mokslo žurnale (Rutkauskas, Žilinskij 2010; Žilinskij, Rutkauskas 2012, du recenzuojamose tarptautinių konferencijų medžiagose (Žilinskij, Kuzminskas 2011; Žilinskij 2012), vienas - recenzuojamoje Lietuvos konferencijos medžiagoje (Žilinskij, Dzikevičius 2008), vienas - nerecenzuojamoje Lietuvos konferencijos medžiagoje (Žilinskij 2009).

Rengiant disertaciją atliktų tyrimų rezultatai buvo paskelbti keturiose mokslinèse konferencijose Lietuvoje ir užsienyje:

- Jaunujų mokslininkų konferencijoje ,Mokslas - Lietuvos ateitis “ 2008 ir 2009 m. Vilniuje;

- Tarptautinejje konferencijoje "International Masaryk conference for Ph.D. students and young researchers" 2011 m. Hradec Králové, Čekija;

- Tarptautineje konferencijoje „Business and management 2012“2012 m. Vilniuje. 


\section{Disertacijos struktūra}

Disertacija sudaro įvadas, trys skyriai ir bendrosios išvados. Taip pat yra 16 priedų.

Darbo apimtis - 116 puslapių, neskaitant priedų, tekste panaudotos 45 numeruotos formulès, 32 paveikslai ir 27 lentelès. Rašant disertacija buvo panaudoti 207 literatūros šaltiniai. 


\section{1}

\section{Pasyvaus investuotojo apsisaugojimo nuo rizikos galimybiu ivertinimas}

Portfelio teorijoje rizikos mažinimas dažnai yra siejamas su investicijų diversifikacija. Intuityviai diversifikacijos esmè ir nauda suvokiama jau seniai, tačiau H. Markowitz (1952), kuris laikomas moderniosios portfelio teorijos pradininku, pirmasis matematiškai pagrindè diversifikacijos efektą ir naudą mažinant investicijų riziką. Pastaroji finansų krizè parodè, kad net diversifikuotas akcijų portfelis negali apsaugoti nuo didelių nuostolių esant globaliam akcijų rinkų nuosmukiui. Didejjanti investicinių priemonių ìvairovè atveria naujas investavimo ir geresnes portfelio diversifikavimo galimybes. Šiame skyriuje keliama prielaida, jog investavimo akcijų rinkoje sisteminè rizika gali būti sumažinta investuojant keliose rinkose, analizuojamos rizikos minimizavimo galimybės sudarant plačiai diversifikuota, ivarius regionus ir turto klases apimanti investicijuc portfeli, vertinamos sudaryto portfelio charakteristikos. Śiame skyriuje atliktos analizès pagrindu parengtas straipsnis tarptautinei doktorantų ir jaunujų mokslininkų Masaryko konferencijai, kuriame ivertintos plačiai diversifikuoto portfelio sudarymo galimybės ir jo efektyvumas (Žilinskij, Kuzminskas 2011). 


\subsection{Mokslininkų siūlomi portfelio diversifikavimo sprendimai}

Efektyvaus investicijų portfelio diversifikavimo problema yra ypač aktuali padidejusio rinkų nepastovumo ir nuosmukio laikotarpiais. Esant palankioms tendencijoms investicijų rinkoje, net turint menkai diversifikuota portfeli galima išvengti nuostolių ir uždirbti pelno. Tačiau išvengti nuostolių finansų krizių laikotarpiu yra labai sudètinga. Finansų krizès paveikia daugelio žmonių socialinę ekonominę gerovę, tai yra svarbus reiškinys, susilaukiantis mokslininkų dėmesio. Mokslininkų darbuose nagrinèjamas krizių poveikis tiek realiai ekonomikai, pinigu srautams, investicijoms (Kroszner 2007; Uctum, Uctum 2011; Milosev et al. 2011), tiek finansų ir investicijų rinkoms (Choudhry 2007; Kenourgios, Padhi 2012; Kenourgios et al. 2011; Samarakoon 2011; Grammatikos, Vermeulen 2012; Kim, Kim 2012). Daugelis finansų krizès poveiki atskirų šalių finansų rinkoms analizavusių mokslininkų nustatė, kad egzistuoja užsikrètimo efektas, kai vienos šalies problemos paveikia kitų šalių finansų rinkas, ir padare išvada, kad tarptautinè akcijų portfelio diversija yra mažesnè, nei tikimasi (Choudhry 2007; Kenourgios, Padhi 2012; Kenourgios et al. 2011; Samarakoon 2011; Kim, Kim 2012), o portfelio diversifikavimas investuojant $i$ akcijas ir i obligacijas gali būti pranašesnis nei vien akcijų ar obligaciju portfelis (Kenourgios, Padhi 2012). Grammatikos, Vermeulen (2012) nustate, kad krizè iš JAV nefinansinio sektoriaus i Europos nefinansini sektoriu persikèlè gerokai labiau, nei finansinio sektoriaus atveju.

Nagrinejant akcijų portfelio diversifikavimą galima išskirti kelias pagrindines jo atmainas. Visu pirma, tai yra diversifikavimas pagal ūkio sektorius. Šis portfelio diversifikavimo būdas yra plačiai taikomas daugelio investuotojų, kadangi gali būti vykdomas vienoje (vietos) rinkoje. Mokslinejje literatūroje pateikiama daug portfelio sudarymo iš vienoje biržoje prekiaujamų skirtingu sektoriu akcijų pavyzdžių (pvz., Nanda et al. 2010; Xidonas et al. 2010a). Kita akcijuc portfelio diversifikavimo atmaina yra tarptautinis portfelis, kuris padeda sumažinti sisteminę konkrečios šalies akcijų kainų svyravimo rizika. Nors, kaip jau buvo minèta, tarptautinès portfelio diversifikacijos nauda krizès laikotarpiu yra mažesnè, nei tikimasi, tačiau yra darbų, pagrindžiančių tarptautinès diversifikacijos nauda. I portfelị dažniausiai siūloma itraukti akcijas besivystančių šalių - Centrinès ir Rytu Europos (Middleton et al. 2008), Balkanų (Syriopoulos 2011), Artimujų Rytų ir Šiaurès Afrikos (Lagoarde-Segot, Lucey 2007), Ramiojo vandenyno pakrančių (Phylaktis, Ravazzolo 2005); arba derinti išsivysčiusių ir besivystančių šaliu akcijas (Chiou 2009; Thapa, Poshakwale 2012, Driessen, Laeven 2007).

Apibendrinant mokslininkų, nagrinèjančių tarptautinio akcijų portfelio sudarymo problematiką gautus rezultatus ir išvadas, be jau minèto mažesnio, nei 
tikimasi, diversifikacijos lygio krizès laikotarpiu, galima pažymèti kelis svarbius tarptautinio diversifikavimo aspektus:

- investicijų rinkų pasirinkimas - investuotojai linkę pasirinkti didesnes, likvidesnes, efektyvesnes rinkas su mažesnèmis sandorių sąnaudomis (Thapa, Poshakwale 2012);

- sandoriu sąnaudos labai svarbios sudarant tarptautiniu mastu diversifikuotą portfeli (Thapa, Poshakwale 2010), jos gali sumažinti ar visiškai nubraukti diversifikacijos naudą (Li et al. 2003);

- informacijos prieinamumas - investuojantys vietineje rinkoje turi informacini pranašuma, leidžianti pasiekti geresnių rezultatų, tad tarptautinis investavimas pasirenkamas tik kaip investavimo konkrečioje rinkoje rizikos mažinimo priemonè (Coeurdacier, Guibaud 2011);

- ribotos ilgalaikès diversifikacijos ir didelio pelningumo galimybès besivystančiose šalyse, tačiau patrauklios trumpalaikio investavimo galimybès (Syriopoulos 2011);

- pažeidžiamų rinkų itraukimas i besivystančių ir išsivysčiusių rinkų akcijų portfeli pagerina jo diversifikaciją (Berger et al. 2011), bet investuotojai turètų būti atsargūs svarstydami investavimo i pažeidžiamų šalių i̇monių akcijas galimybes (Lagoarde-Segot, Lucey 2007);

- tarptautiniai investuotojai susiduria ne tik su akcijuc, i kurias investuojama, bet ir su valiutų kursų svyravimo rizika, nors ši rizika ir gali būti valdoma (Olma, Siegel 2004)

- Eiling et al. (2012), Meric et al. (2008) bei Ehling ir Ramos (2006) atlikti tyrimai neleido vienareikšmiškai atsakyti, koks akcijų portfelio diversifikavimo būdas yra geresnis (pagal sektorių ar pagal šalis), todèl tikslinga yra diversifikuoti investicijas derinant abu būdus.

Kadangi tarptautinis akcijų portfelis neužtikrina pakankamos investicijų portfelio diversifikacijos, iškyla būtinybè i investicijų portfelį itraukti kitus aktyvus. Mokslinèje literatūroje dažniausiai nuosavybès vertybinius popierius (akcijas) siūloma derinti su fiksuotos grąžos vertybiniais popieriais (obligacijomis), vertinama tokios diversifikacijos nauda (Kim et al. 2006), ieškoma optimalių investicijoms skirtų lěšų paskirstymo proporcijų tarp akcijų, obligacijų ir grynujų (Bange, Miller 2004; Bange et al. 2008).

Pasiūlymai derinti akcijas ir obligacijas bei ju igyvendinimas praktikoje yra labai paplitę, nes tai yra tradicinès, investuotojams puikiai žinomos, gerai suprantamos investicinès priemonès. Vystantis finansų rinkoms, didejant investicinių priemonių ivvairovei (išvestiniams sandoriams, investicijų fondams ir pan.) atsirado galimybès i portfelị itraukti ir kitas turto klases. Sparčiai plètojantis nekilnojamojo turto rinkai, mokslininkų darbuose daug dèmesio buvo kreipiama portfelio diversifikavimui itraukiant i jo sudèti nekilnojamaji turtą (Seiler et al. 1999; Bikas, Laurinavičius 2009; Fugazza 2007; Lee, Stevenson 
2006; Chun et al. 2004; Delcourt, Petitjean 2011). Pažymètina, kad nekilnojamojo turto itraukimas į investicijų portfelį numatytas taip pat darbuose, publikuotuose sprogus nekilnojamojo turto burbului (pvz., Bikas, Laurinavičius 2009; Delcourt, Petitjean 2011). Nekilnojamojo turto itraukimo diversifikuojant portfeli naudą taip pat nustate Lin ir Lin (2011), Lee et al. (2012), Payne ir Sahu (2004), Heaney ir Sriananthakumar (2012), nagrinejantys nekilnojamojo turto ir akcijų rinkų tarpusavio integraciją ir graž̌os koreliacija, tačiau pažymèjo, jog nekilnojamojo turto ir akcijų rinkos gali turèti skirtingas tarpusavio priklausomybes esant skirtingai ekonominei ir politinei aplinkai (Lin, Lin 2011), grąžos koreliacijos lygis keičiasi bėgant laikui (Heaney, Sriananthakumar 2012), koreliacijos ypač padidèjo pastarosios finansų krizès metu.

Pastaraisiais metais vis populiaresnè investavimo priemonè tampa prekès (metalai, energijos ištekliai, žemès ūkio prekès). Investuoti i prekes galima tiesiogiai (pvz., nusiperkant aukso luitus) arba netiesiogiai (isigyjant finansines priemones, kurių grąža priklauso nuo prekių kainų kitimo rinkoje). Didejant prekių kaip investicinio aktyvo populiarumui, jų investicinių savybių tyrimas tampa aktuali mokslinių tyrimų tema. Mokslininkų atlikti prekių investicinių savybių tyrimai yra apibendrinti 1.1 lentelèje.

1.1 lentelè. Prekių investicinių savybių moksliniai tyrimai

Table 1.1. Commodities' investment features analyses

\begin{tabular}{|c|c|}
\hline Šaltinis & Tyrimo aspektas \\
\hline $\begin{array}{l}\text { Cheung, Miu 2010; Daskalaki, } \\
\text { Skiadopoulos } 2011\end{array}$ & $\begin{array}{l}\text { Portfelio diversifikavimas investuojant i akcijas, } \\
\text { obligacijas ir prekes }\end{array}$ \\
\hline Shafiee, Topal 2010 & Aukso kainos prognozavimas \\
\hline Hammoudeh et al. 2011 & Investicijų $i$ tauriuosius metalus rizikos valdymas \\
\hline $\begin{array}{l}\text { Narayan, Liu 2011; Morales, } \\
\text { Andreosso-O'Callaghan } 2011\end{array}$ & $\begin{array}{l}\text { Krizių ir sukretimų poveikis aukso, sidabro, } \\
\text { platinos, paladžio, vario, aliuminio, geležies rūdos, } \\
\text { švino, nikelio, alavo ir cinko kainoms }\end{array}$ \\
\hline Fernandez 2008 & $\begin{array}{l}\text { Apsidraudimo portfelio sudarymas iš grynuju, } \\
\text { aliuminio, vario, švino, nikelio, cinko ir alavo }\end{array}$ \\
\hline Bhar, Hammoudeh 2011 & $\begin{array}{l}\text { Prekių (naftos, vario, aukso ir sidabro) rinkų bei } \\
\text { finansinių rodikliu (palūkanu normos, valiutos } \\
\text { kurso, pasaulio akciju indekso) tarpusavio } \\
\text { priklausomybès tyrimas }\end{array}$ \\
\hline Vivian, Wohar 2012 & $\begin{array}{l}\text { Gyvūnu produktŭ, energijos ištekliu, grūdu, } \\
\text { pramoninių metalu, pramonès prekių, tauriujų } \\
\text { metalų kainų ir akciju indeksų kintamumo analizè }\end{array}$ \\
\hline $\begin{array}{l}\text { Sari et al. 2010; Ghosh 2011; } \\
\text { Joy 2011; Hammoudeh, Yuan } \\
2008\end{array}$ & $\begin{array}{l}\text { Metalu (aukso, sidabro, platinos, paladžio, vario), } \\
\text { naftos kainos ir valiutos kurso kitimo tarpusavio } \\
\text { priklausomybès tyrimas }\end{array}$ \\
\hline
\end{tabular}


1.1 lentelès pabaiga

\begin{tabular}{|l|l|}
\hline $\begin{array}{l}\text { Elder } \text { et al. 2012; } \\
\text { Batten et al. 2010 }\end{array}$ & $\begin{array}{l}\text { Makroekonominių veiksnių ir naujienų poveikis } \\
\text { tauriujų metalų (aukso, sidabro, platinos, paladžio, } \\
\text { vario) kainoms }\end{array}$ \\
\hline Baur, McDermott 2010 & Aukso ir akcijų rinkos priklausomybės tyrimas \\
\hline $\begin{array}{l}\text { Nazlioglu, Soytas 2011a; } \\
\text { Nazlioglu, Soytas 2011b }\end{array}$ & $\begin{array}{l}\text { Naftos kainų ir valiutos kurso poveikio žemès ūkio } \\
\text { prekių kainoms tyrimas }\end{array}$ \\
\hline $\begin{array}{l}\text { Arouri, Nguyen 2010; Arouri } \\
\text { et al. 2011; Geman, Kharoubi } \\
2008\end{array}$ & $\begin{array}{l}\text { Naftos ir akcijų rinkuz tarpusavio priklausomybès ir } \\
\text { naftos itraukimo i akcijuc portfeli tikslingumo } \\
\text { tyrimas }\end{array}$ \\
\hline Zhang, Wei 2010 & $\begin{array}{l}\text { Naftos ir aukso kainu tarpusavio priklausomybès } \\
\text { tyrimas }\end{array}$ \\
\hline
\end{tabular}

Saltinis: sudaryta autoriaus

Išnagrinejjus 1.1 lentelèje minimus tyrimus, galima pateikti kelis pastebejjimus, galinčius turèti itakos priimant sprendimus dèl plačiai diversifikuoto portfelio sudarymo:

- nepaisant nemažo straipsnių šia tema skaičiaus, didžioji dalis jų yra paskelbta išteklių analizès, o ne ekonomikos tematikos leidiniuose, t. y. prekių kainų, jų priklausomybių analizè atliekama ne vertinant prekes kaip investicini produkta, o siekiant apsisaugoti nuo išteklių kainos svyravimo rizikos;

- didejantis prekių suvartojimas tokiose rinkose kaip Kinija ar Indija gali padidinti prekių kainas, todèl prekių rinkos patrauklumas investicijoms vis dideja (Morales, Andreosso-O'Callaghan 2011);

- Naftos itraukimas i portfelị leidžia pagerinti portfelio pelningumo ir rizikos charakteristikas (Arouri, Nguyen 2010)

- tyrimų rezultatai neleidžia vienareikšmiškai įvertinti diversifikacijos itraukiant i portfeli prekes naudos - Cheung, Miu (2010) nepaneigdami ilgalaikès diversifikacijos naudos nustatè, kad jos nèra, kai to labiausiai reikia (rinkų smukimo laikotarpiu), nors Baur, McDermott (2010) padare išvadą, kad diversifikacijos nauda yra minimali besivystančioms rinkoms, tačiau išsivysčiusioms rinkoms per pati pastarosios krizès piką tapo puiki saugi investicija, o Daskalaki, Skiadopoulos (2011) nustatè prekių nauda ne vidurkio-dispersijos požiūriu besivadovaujantiems investuotojams, tačiau nenustate naudos vidurkio-dispersijos investuotojams;

- Joy (2011) nustatytos neigiamos koreliacijos tarp aukso kainos ir dolerio kurso (nors ir nepastovios) sudaro prielaidas tikètis efektyvios diversifikacijos derinant šiuos aktyvus investicijų portfelyje.

Joy (2011) nustatytos neigiamos koreliacijos tarp aukso kainos ir dolerio kurso iškelia klausimą dèl valiutų įtraukimo i investicini portfelį. Nagrinejjant mokslinius darbus, susijusius su valiutų itraukimu i investicijų portfelį, reikia pastebėti, kad daugiausia jų yra nukreipta į apsaugą nuo valiutų kursų svyravimo 
turint tarptautini investicijų i kitus aktyvus (dažniausiai akcijas) portfeli (pvz., Hamza et al. 2007; Roon et al. 2003; Tee 2009; Kim 2012; Walker 2008), taip pat $i$ investicijų skirtingomis valiutoms efektyvumo vertinimą (pvz., Christou et al. 1998), tačiau straipsnių, kuriuose būtų tiriamos valiutų, kaip investavimo priemonių, derinimo su kitais aktyvais viename portfelyje galimybès, nepavyko rasti.

Apibendrinant išnagrinètus mokslininkų pasiūlymus dèl aktyvų ịtraukimo ị plačiai diversifikuotą investiciju portfelị ir įvertinus papildomų aktyvų įtraukimo galimybes, 1.1 paveiksle yra pateikiama bendra potencialių plačiai diversifikuoto portfelio aktyvų nomenklatūra.

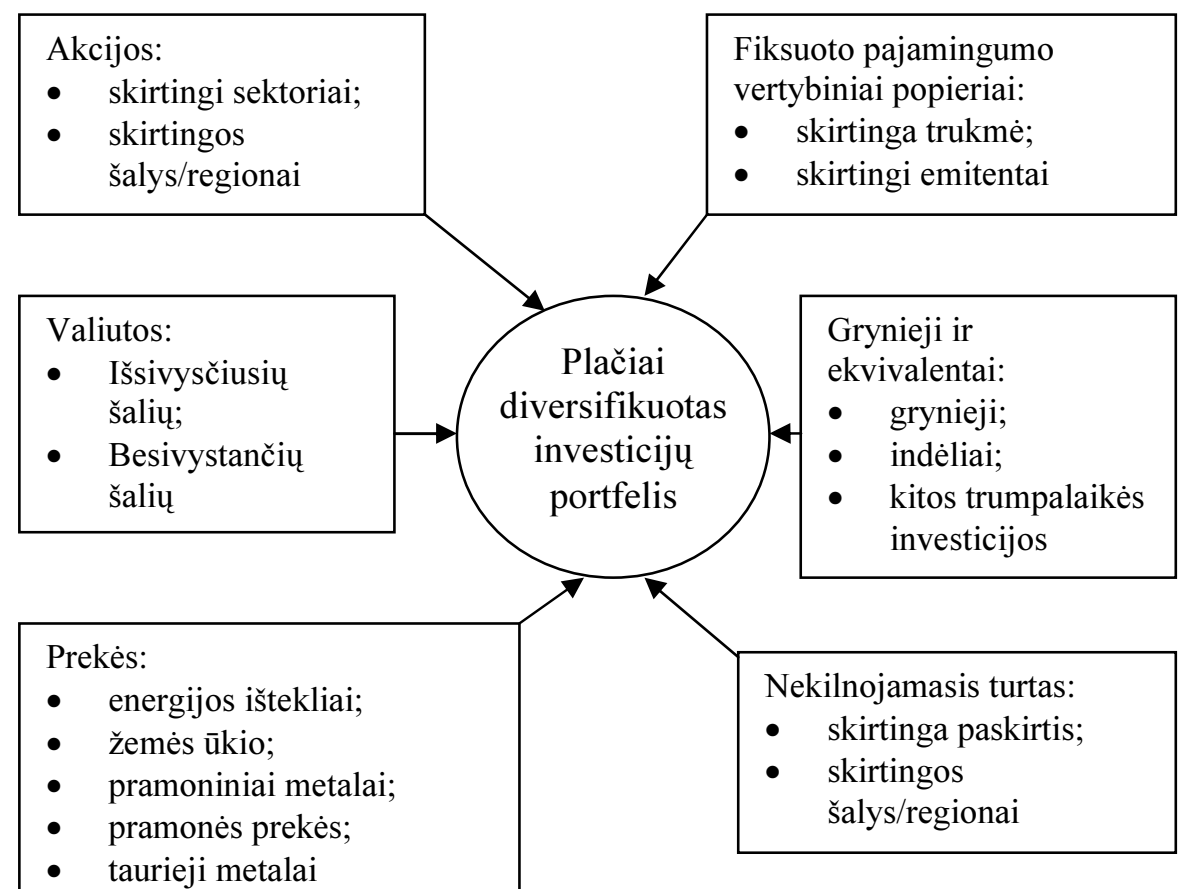

1.1 pav. Plačiai diversifikuotą portfeli galintys sudaryti aktyvai

Fig. 1.1. Actives which could be involved in widely diversified portfolio Šaltinis: sudaryta autoriaus

1.1 paveikslas parodo, jog investuotojai turi dideli aktyvų, galimų itraukti i investicijų portfeli, pasirinkimą ir bėgant laikui tikètina, kad aktyvų pasirinkimas tik didès. Didelis aktyvu pasirinkimas sukuria prielaidas geresnei portfelio diversifikacijai - didejanti atskirų prekių kaina sukuria prielaidas prekių 
eksportuotojų šalių ekonomikų ir vertybinių popierių rinkos grąžai augti, bet turi neigiamos itakos šalims ar regionams, importuojantiems brangstančias prekes, visa tai taip pat turi įtakos valiutų kursų pokyčiams.

\subsection{Investicinių priemonių pasirinkimas, jų charakteristikų vertinimas}

Atliekant literatūros analizę buvo išnagrinètos pagrindinès turto grupès, kurios esant dabartiniam rinkų išvystymo lygiui gali būti naudojamos investiciniais tikslais, tačiau investavimas ị kai kurias grupes tiesiogiai perkant turtą gali būti probleminis (pvz., reikia daug investicijų norint įtraukti i portfeli nekilnojamaji turta; nusipirkus prekes iškyla jų saugojimo problema, o pvz., žemès ūkio prekès genda ir negalima laukti palankių kainų pokyčių). Be to, nèra bendros rinkos, kurioje būtų galima tiesiogiai prekiauti visais išvardintais aktyvais ar bent jų išankstiniais sandoriais, o dalyvavimas keliose rinkose padidintų investavimo išlaidas. Atsižvelgiant $\mathfrak{i}$ tai, tikslinga sudaryti portfelị ne tiesiogiai issigyjant pasirinktą turtą, o investuojant į finansines priemones, kurių grąža priklauso nuo minètų aktyvų kainų kitimo.

\subsubsection{Investicinių priemonių pasirinkimas}

Pasirenkant konkrečią investavimo priemonę pagrindinis dèmesys buvo kreipiamas i kelis aspektus:

- investicine priemone turi būti prekiaujama rinkoje;

- nedidelès sandorių sąnaudos;

- galimybė operatyviai sudaryti sandorius;

- galimybé pirkti nedidelius investicinių priemonių kiekius;

- pakankamas istorinių (grąžos) duomenų kiekis analizei atlikti.

Geriausiai minètus kriterijus atitiko pastaruoju metu vis populiaresnè investicinè priemonè tampantys biržoje prekiaujami fondai - BPF (angl. Exchange traded funds - ETF). Tai pagrindžia mokslininkų atsiliepimai ir mokslinių darbų, kuriuose buvo analizuoti BPF, rezultatai:

- 67 procentai investavimo profesionalu BPF laiko inovatyviausia pastarujų dviejų dešimtmečių investicine priemone (DiLellio, Stanley 2011);

- Biržoje prekiaujami fondai suteikia naujų galimybių, kurių nesuteikè tradiciniai investicijų fondai (Agapova 2011);

- Investiciju i auksą plètrai įtakos turès BPF plètra, nes jie padidina rinkos skaidrumą ir naudodamiesi jais i auksą investuoja net tie investuotojai, kurie nebūtų jo pirkę tiesiogiai (Morales, Andreosso-O'Callaghan 2011). 
- BPF yra geresnis investavimo būdas nei tiesioginè prekyba prekių ateities sandoriais (Yamori 2011);

- Nors Blitz ir Huij (2012) nustatè, kad dèl fondo išlaidų ir dividendų apmokestinimo besivystančių rinkų BPF grąža gali būti apie 85 baziniais punktais per metus mažesnè nei lyginamujuc indeksų, investuotojams tikslinga naudoti netiesiogines investavimo priemones - biržoje prekiaujamus fondus sudarant tarptautiniu mastu diversifikuotus portfelius (Huang, Lin 2011);

- BPF išlaidos yra 2-3 kartus mažesnès nei aktyviai valdomu investicinių fondų (Macijauskas 2011), BPF užtikrina mažesni pirkimo-pardavimo kainų skirtumą ir mažesni informacijos asimetriškumą nei atskiros akcijos (ChelleySteeley, Park 2011);

- Pasyvi investicijų strategija naudojant BPF gali duoti daugiau naudos nei aktyvi investicijų strategija naudojant uždaruosius investicinius fondus (Harper et al. 2006).

Visi išvardinti teiginiai pagrindžia, kad BPF, kaip investicinè priemonè, puikiai tinka plačiai diversifikuotam portfeliui sudaryti.

Svertiniai BPF gali užtikrinti grąža, kuri yra keleriopai didesnè už pasirinktos rinkos grąžą (Charupat, Miu 2011), tačiau graža nepadidès proporcingai taikomam finansiniam svertui (Jarrow 2010). Atsižvelgiant $i \underset{\text { tai }}{\text { ir }} \mathfrak{i}$ palyginti mažą svertinių BPF paplitimą kad būtų galima iš jų sudaryti plačiai diversifikuotą investicijų portfeli, šiame tyrime svertiniai BPF nebus analizuojami.

Pasirenkant konkrečius BPF buvo vertinti 3 pagrindiniai kriterijai - istorinių duomenų analizei pakankamumas (vertinant plačiai diversifikuoto portfelio, kaip apsisaugojimo nuo rizikos priemonès, efektyvumą labai svarbus yra pastarosios globalios finansų krizès laikotarpis, tad turètų būti duomenų surinkimo galimybė bent nuo 2007 metu); BPF turto dydis (nes jis netiesiogiai parodo BPF likviduma, galimybę greitai parduoti BPF vienetus) ir galima nauda portfelyje (pasirenkami BPF, kurie galètų labai mažai ar net neigiamai koreliuoti su kitais BPF).

Iš 1.1 paveiksle parodytų aktyvų grupių i tyrimą nuspręsta ịtraukti keturias: akcijas, fiksuoto pajamingumo vertybinius popierius (obligacijas), valiutas ir prekes. Grynujų ir ekvivalentų nuspręsta atsisakyti, kadangi tai yra nerizikingos investicijos ir jų itraukimas i analizę nèra tikslingas - kiek turèti grynujų pinigų kiekvienas investuotojas gali pasirinkti savarankiškai, priklausomai nuo polinkio rizikuoti - be to, šios grupés nebuvimą gali kompensuoti trumpalaikių obligacijų BPF. Nekilnojamojo turto atsisakyta, kadangi, kaip jau buvo mineta analizuojant šios tematikos kitų mokslininkų darbus, pastarosios finansų krizès metu nekilnojamojo turto ir akcijų kainų koreliacijos buvo smarkiai padidejusios.

Iš viso tyrimui atlikti buvo atrinkti 24 biržoje prekiaujami fondai -8 akcijų, 3 obligacijų, 8 valiutų ir 5 prekių (1.2 lentelè). 
1.2 lentelè. Analizei atrinkti BPF

Table 1.2. ETF's selected for analysis

\begin{tabular}{|c|c|c|}
\hline Biržoje prekiaujamas fondas & $\begin{array}{c}\text { Turto vertė, } \\
\text { USD }\end{array}$ & Trumpinys \\
\hline \multicolumn{3}{|l|}{ Akciju BPF } \\
\hline iShares MSCI Canada Index Fund & 6,61 Mlrd. & EWC \\
\hline iShares MSCI South Africa Index Fund & 659,42 Mln. & EZA \\
\hline iShares MSCI Pacific ex-Japan Index Fund & 4,34 Mlrd. & EPP \\
\hline iShares S\&P Latin America 40 Index Fund & 2,69 Mlrd. & ILF \\
\hline Dow Jones EURO STOXX 50 ETF & 191,58 Mln. & FEZ \\
\hline SPDR S\&P $500 \mathrm{ETF}$ & 95,31 Mlrd. & SPY \\
\hline SPDR S\&P Emerging Europe ETF & 325,24 Mln. & GUR \\
\hline SPDR S\&P Emerging Middle East \& Africa ETF & 165,80 Mln. & GAF \\
\hline \multicolumn{3}{|l|}{ Obligacijų BPF } \\
\hline Short-Term Bond ETF & 21,47 Mlrd. & BSV \\
\hline Inter-Term Bond ETF & 11,68 Mlrd. & BIV \\
\hline Long-Term Bond ETF & 4,03 Mlrd. & BLV \\
\hline \multicolumn{3}{|l|}{ Valiutos BPF } \\
\hline CurrencyShares Australian Dollar Trust ETF & 856,44 Mln. & FXA \\
\hline CurrencyShares Japanese Yen Trust ETF & 194,69 Mln. & FXY \\
\hline CurrencyShares Canadian Dollar Trust ETF & 780,83 Mln. & FXC \\
\hline CurrencyShares British Pound Sterling Trust ETF & 140,86 Mln. & FXB \\
\hline CurrencyShares Euro Trust ETF & 384,34 Mln. & FXE \\
\hline CurrencyShares Swedish Krona Trust ETF & 123,92 Mln. & FXS \\
\hline CurrencyShares Mexican Peso Trust ETF & 34,77 Mln. & FXM \\
\hline PowerShares DB US Dollar Index Bullish Fund & 798,88 Mln. & UUP \\
\hline \multicolumn{3}{|l|}{ Prekių BPF } \\
\hline streetTRACKS Gold Shares ETF & 60,68 Mlrd. & GLD \\
\hline iShares Silver Trust Fund & 17,30 Mlrd. & SLV \\
\hline PowerShares DB Base Metals Fund & $629,10 \mathrm{Mln}$. & DBB \\
\hline PowerShares DB Energy Fund & 248,09 Mln. & DBE \\
\hline PowerShares DB Agriculture Fund & 3,81 Mlrd. & DBA \\
\hline
\end{tabular}

Šaltinis: sudaryta autoriaus, remiantis finance.yahoo.com duomenimis

Siekiant geresnès diversifikacijos akcijų BPF buvo atrinkti pagal skirtingus regionus (išsivysčiusias ir besivystančias rinkas). Diversifikavimo pagal sektorių atsisakyta, kadangi kiekvieno regiono BPF jau yra diversifikuoti pagal sektorius (jų grąžą lemia skirtingų sektorių akcijų grązos). Tyrimui taip pat atrinkti skirtingos trukmès obligacijų BPF - ilgalaikès obligacijos gali būti pelningesnès, o trumpalaikès gali būti naudingos mažinant investicijų portfelio riziką. Tyrimui atrinktos tiek išsivysčiusių šalių saugios valiutos, kurių kaina linkusi dideti esant neapibrežtumui ir nuosmukiui finansų rinkose, tiek besivystančių šalių, kurių kurso augimas labiau tikètinas ekonominio pakilimo metu. Prekių BPF apima 
tauriuosius metalus, kurie gali būti naudojami kaip saugi investicija rinkos nuosmukio laikotarpiu, pagrindinius metalus ir energijos išteklius - kurių kainų kilimas labiau tikètinas pramonès plètros laikotarpiais ir žemès ūkio prekių vieno iš pagrindinių maisto šaltinių.

\subsubsection{Atrinktų BPF pagrindinių charakteristikų vertinimas}

Prieš pradedant sudaryti plačiai diversifikuotą portfeli reikia įvertinti pagrindines analizuojamų BPF charakteristikas. İvertinus istorinių duomenų pakankamumą „ex post“ analizei pasirinktas 2007-04-10-2011-02-10 laikotarpis. Pagrindinès charakteristikos pateikiamos 1.3-1.6 lentelèse.

1.3 lentelè. Pagrindinès akcijų biržoje prekiaujamų fondų charakteristikos

Table 1.3. Stock exchange traded funds' main characteristics

\begin{tabular}{|l|c|r|r|r|r|r|r|r|}
\hline BPF & EWC & \multicolumn{1}{c|}{ EZA } & \multicolumn{1}{c|}{ EPP } & \multicolumn{1}{c|}{ ILF } & \multicolumn{1}{c|}{ FEZ } & \multicolumn{1}{c|}{ SPY } & \multicolumn{1}{c|}{ GUR } & \multicolumn{1}{c|}{ GAF } \\
\hline $\mathrm{R}^{1}$ & 0,970 & 0,754 & 0,730 & 1,461 & $-0,086$ & 0,254 & 0,462 & 0,611 \\
\hline $\mathrm{SD}^{2}$ & 9,237 & 9,388 & 9,467 & 10,660 & 9,553 & 7,289 & 11,983 & 7,576 \\
\hline $\mathrm{SD} / \mathrm{R}^{3}$ & 9,526 & 12,445 & 12,975 & 7,298 & $-111,49$ & 28,649 & 25,922 & 12,404 \\
\hline
\end{tabular}

Saltinis: sudaryta autoriaus

1.4 lentelè. Pagrindinės obligacijų biržoje prekiaujamų fondų charakteristikos

Table 1.4. Bond exchange traded funds' main characteristics

\begin{tabular}{|l|r|r|r|}
\hline BPF & \multicolumn{1}{|c|}{ BSV } & \multicolumn{1}{c|}{ BIV } & \multicolumn{1}{c|}{ BLV } \\
\hline $\mathrm{R}$ & 0,408 & 0,577 & 0,526 \\
\hline $\mathrm{SD}$ & 1,053 & 2,964 & 3,415 \\
\hline $\mathrm{SD} / \mathrm{R}$ & 2,584 & 5,139 & 6,486 \\
\hline
\end{tabular}

Saltinis: sudaryta autoriaus

1.5 lentelè. Pagrindinès valiutų biržoje prekiaujamų fondų charakteristikos

Table 1.5. Currency exchange traded funds' main characteristics

\begin{tabular}{|l|c|c|c|r|r|r|r|r|}
\hline BPF & FXA & FXY & FXC & \multicolumn{1}{|c|}{ FXB } & \multicolumn{1}{c|}{ FXE } & \multicolumn{1}{c|}{ FXS } & \multicolumn{1}{c|}{ FXM } & \multicolumn{1}{c|}{ UUP } \\
\hline $\mathrm{R}$ & 0,791 & 0,806 & 0,416 & $-0,310$ & 0,138 & 0,275 & 0,171 & $-0,168$ \\
\hline $\mathrm{SD}$ & 5,202 & 3,208 & 3,505 & 3,569 & 3,431 & 4,224 & 4,499 & 2,721 \\
\hline $\mathrm{SD} / \mathrm{R}$ & 6,579 & 3,982 & 8,430 & $-11,497$ & 24,854 & 15,333 & 26,373 & $-16,164$ \\
\hline
\end{tabular}

Śaltinis: sudaryta autoriaus

\footnotetext{
${ }^{1} \mathrm{BPF}$ vidutinè grąža

${ }^{2}$ BPF rizika (standartinis nuokrypis)

${ }^{3}$ Rizika, tenkanti vienam gražos vienetui
} 
1.6 lentelè. Pagrindinès prekių biržoje prekiaujamų fondų charakteristikos

Table 1.6. Commodity exchange traded funds' main characteristics

\begin{tabular}{|l|r|r|r|r|r|}
\hline BPF & GLD & \multicolumn{1}{c|}{ SLV } & \multicolumn{1}{c|}{ DBB } & \multicolumn{1}{c|}{ DBE } & \multicolumn{1}{c|}{ DBA } \\
\hline $\mathrm{R}$ & 1,673 & 2,164 & 0,354 & 0,578 & 0,972 \\
\hline $\mathrm{SD}$ & 5,614 & 9,895 & 8,962 & 9,769 & 7,003 \\
\hline $\mathrm{SD} / \mathrm{R}$ & 3,355 & 4,572 & 25,311 & 16,894 & 7,202 \\
\hline
\end{tabular}

Šaltinis: sudaryta autoriaus

Iš 1.3-1.6 lentelių matyti, kad analizuotu laikotarpiu geriausią grąžą turejjo tauriujų metalų (aukso ir sidabro) BPF. Pelningiausias sidabro BPF taip pat buvo vienas iš rizikingiausių. Geriausias rizikos, tenkančios vienam grąžos vienetui, rodiklis analizuotu laikotarpiu buvo trumpalaikių obligacijų BPF, kiek prastesni - aukso, Japonijos jenos ir sidabro BPF.

Sudarant plačiai diversifikuotą portfelị ir siekiant minimizuoti investicijuc riziką yra svarbios ne tiek kiekvienos investicinès priemonès charakteristikos, kiek jų grąžos kitimo tarpusavio koreliacijos/kovariacijos. Visu analizuotų BPF grąžos kitimo dinamika yra pateikiama $1.2-1.5$ paveiksluose. Iš 1.2 paveikslo matyti, kad didžiausias akcijų BPF nuosmukis buvo 2008-09-10-2008-10-10 laikotarpiu. Šis laikotarpis yra itin svarbus nagrinejant pasyvaus investuotojo apsisaugojimo nuo nuostoliu problema, nes jis gali parodyti, kurios investicinès priemonès gali leisti sumažinti nuostolius ar net uždirbti esant pačiam finansų krizès pikui.

Palyginę 1.2-1.5 paveikslus matome, kad esant didžiausiam nuosmukiui akcijų rinkose, tuo pat metu buvo didžiausias obligacijų BPF nuosmukis, taigi investuotojų dažnai taikomas ir investicijų konsultantų siūlomas portfelio diversifikavimas derinant akcijas ir obligacijas neleistų išvengti ženklių nuostolių per pati krizès piką. Tačiau vertinant prekių ir valiutu BPF rezultatus galima pastebèti, kad trims BPF (FXY, UUP ir GLD) per krizès piką ne tik pavyko išvengti nuostoliu, bet ir uždirbti pelno. Šie BPF atspindi kainų pokyčius taip vadinamujų saugių aktyvų - Japonijos jenos, JAV dolerio ir aukso. Faktas, kad per pati krizès piką ir smunkant daugeliui rinkų kai kuriems aktyvams pavyko uždirbti pelno, tik patvirtina, jog iš tikrujų egzistuoja prielaidos, leidžiančios teigti, jog galima sukurti investiciju portfeli, leidžiantį ženkliai sumažinti investicijų riziką net padidejusio rinkų nepastovumo ir krizių laikotarpiais. 

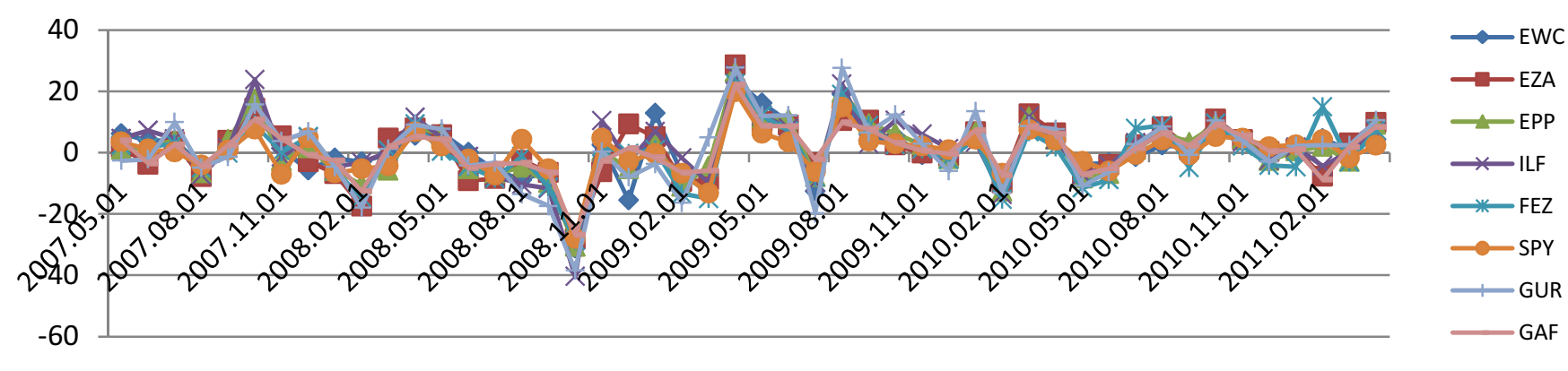

1.2 pav. Akcijų biržoje prekiaujamų fondų grąžos svyravimai, \%

Fig. 1.2. Stock exchange traded funds' return fluctuations, $\%$ Šaltinis: sudaryta autoriaus

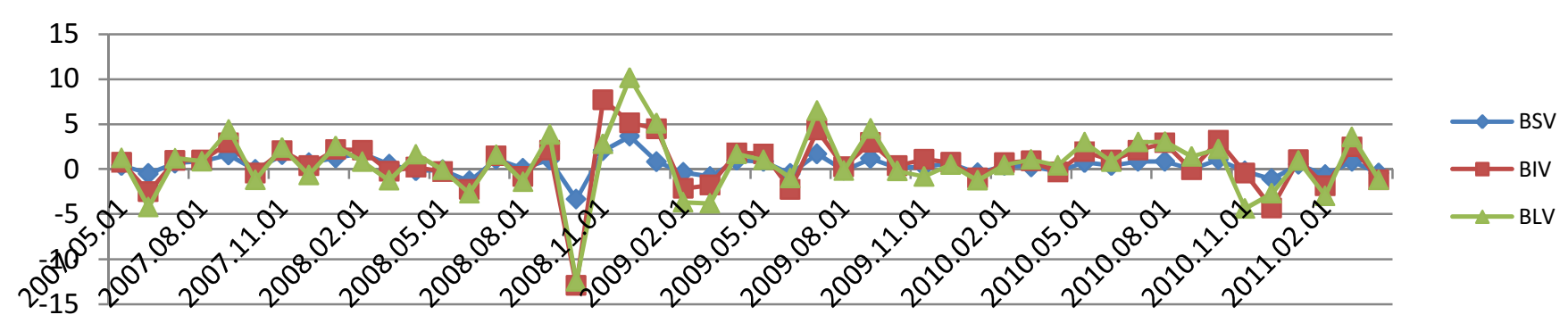

1.3 pav. Obligacijų biržoje prekiaujamų fondų grąžos svyravimai, \%

Fig. 1.3. Bond exchange traded funds' return fluctuations, $\%$ Šaltinis: sudaryta autoriaus 

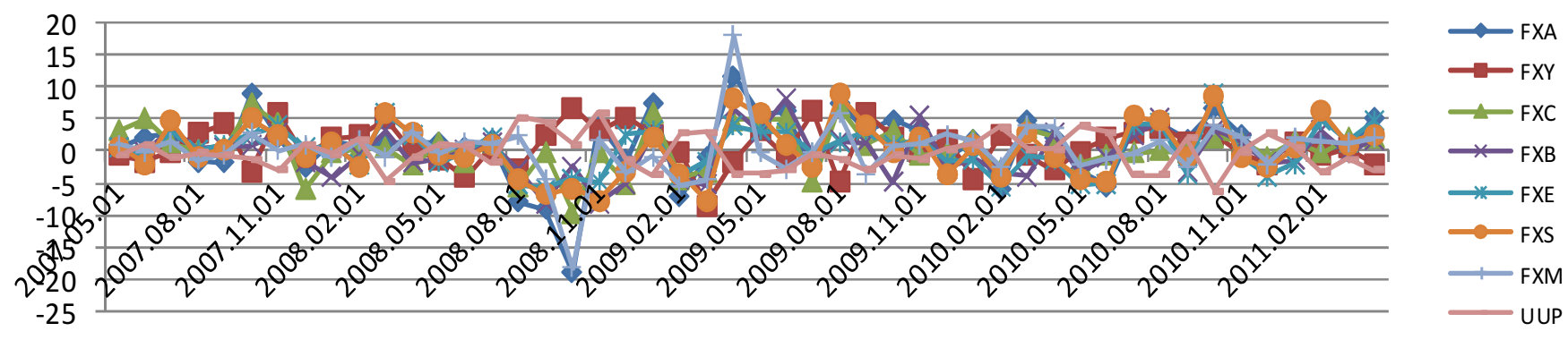

1.4 pav. Valiutų biržoje prekiaujamų fondų grąžos svyravimai, \%

Fig. 1.4. Currency exchange traded funds' return fluctuations, $\%$ Šaltinis: sudaryta autoriaus
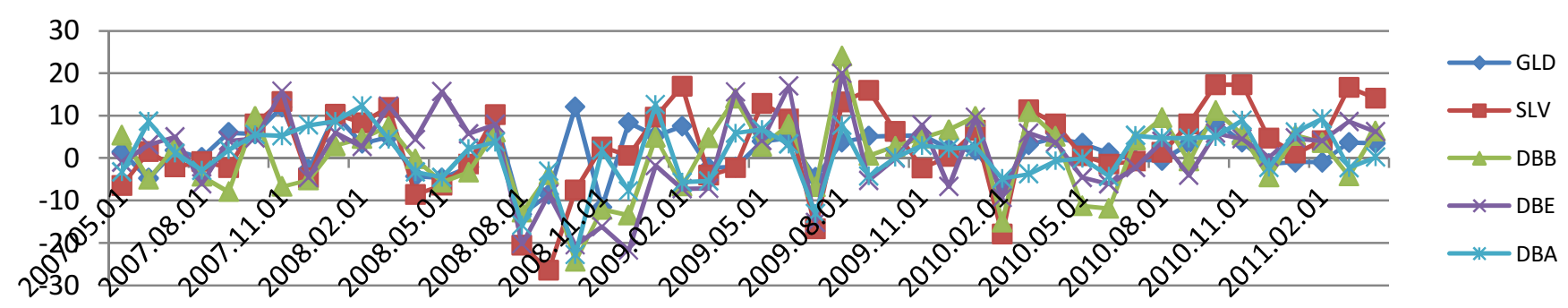

1.5 pav. Prekių biržoje prekiaujamų fondų grąžos svyravimai, \%

Fig. 1.5. Commodity exchange traded funds' return fluctuations, $\%$ Šaltinis: sudaryta autoriaus 
Atlikta grafinè analizė parodè kainų pokyčius per pati krizès piką, tačiau ji neatspindi viso analizuoto laikotarpio. BPF grąžos svyravimų tarpusavio priklausomybes parodo A priede pateikta koreliacijos matrica. Iš jos matyti, kad daugiausiai neigiamų koreliacijų turi FXY ir UUP BPF, jų koreliacijų su visais kitais BPF vidurkiai yra neigiami, o mažiausias teigiamas koreliacijų vidurkis yra tarp GLD ir visų kitų BPF. Tai iš esmès patvirtina preliminarias išvadas, padarytas atlikus grafinę grąžos kitimo analizę. Pažymètina, kad akcijų BPF grąžos yra labai koreliuotos (mažiausias koreliacijos koeficientas - 0,77).

Šio skyriaus ižangoje buvo iškelta prielaida, jog investavimo vienoje (akcijų) rinkoje sisteminè rizika gali būti sumažinta investuojant keliose rinkose. Mokslininkų darbuose (Billio et al. 2012; Suh 2012; Haung et al. 2009; Huang et al. 2011; Bartram 2007) dažniausiai analizuojama finansų sektoriaus sistemine rizika, siūlomi skirtingi, dažnai sudètingi sisteminès rizikos vertinimo metodai: principinių komponentų analizè, Granger priežastingumo ryšiai (Billio et al. 2012); sukaupta anomali grąža, struktūrizuotas kredito rizikos modelis, akcijų opcionų kainos (Bartram 2007); apsidraudimo nuo finansinių problemų kainos (Haung et al. 2009), tačiau kaip pažymi Suh (2012) grąžos koreliacijos yra pagrindinis veiksnys, kurị finansų reguliuotojai turètų turèti omenyje vertindami sisteminę riziką. Grąžos koreliacijos yra paprastas, stiprus, žvelgiantis i prieki, savalaikis rizikos indikatorius, kuris priešingai nei daugelis kitu sisteminès rizikos matų nesusiduria su duomenų apribojimo ir netinkamo modelio aprašymo problema (Patro et al. 2012). Taigi A priede pateikti koreliacijos koeficientai leidžia teigti, jog investavimas skirtingose rinkose leidžia pasiekti riziką, mažesnę nei sisteminè akcijų rinkos rizika (1.6 pav.).

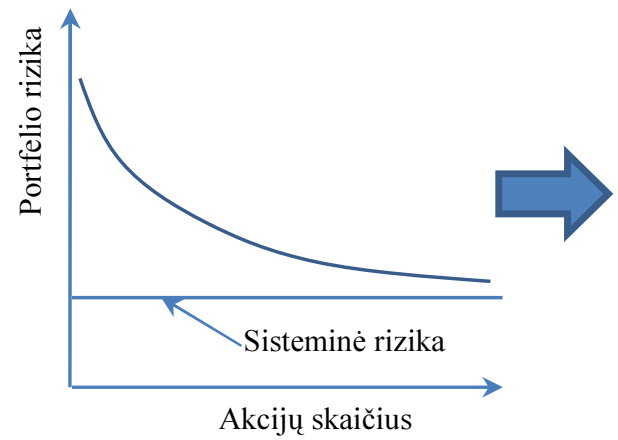

Akcijų rinkos rizika

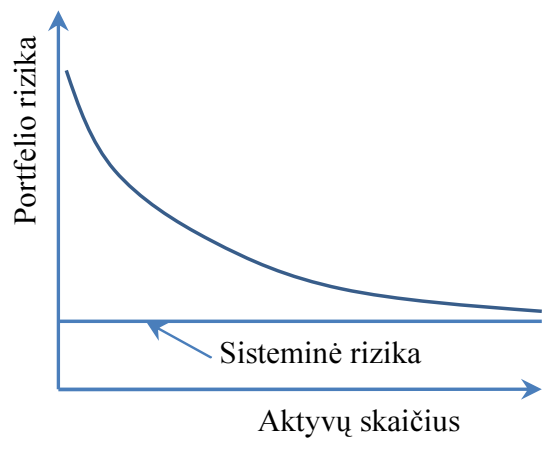

Rizika investuojant skirtingose rinkose

1.6 pav. Sisteminè rizika investuojant akcijų ir keliose rinkose

Fig. 1.6. Systemic risk investing in stock and several markets

Šaltinis: sudaryta autoriaus 
1.6 paveiksle pavaizduotas vienos rinkos (šiuo atveju akcijų) sisteminès rizikos mažinimo investuojant keliose rinkose efektas leidžia daryti prielaida, jog egzistuoja tokia portfelio aktyvų kombinacija, kuri leidžia net pasyviems investuotojams ženkliai sumažinti investicijų riziką.

\subsection{Plačiai diversifikuoto portfelio sudarymas ir jo rezultatu ivertinimas}

Ankstesniame poskyryje buvo aptartos pagrindinès prielaidos leidžiančios manyti, kad plačiai diversifikuotas portfelis leidžia ženkliai sumažinti investiciju rizika. Tačiau realus plačiai diversifikuoto portfelio grąžos ir rizikos lygis gali būti įvertintas tik sudarant portfelị ir testuojant jị realiomis rinkos sąlygomis.

\subsubsection{Plačiai diversifikuoto portfelio sudarymas}

Plačiai diversifikuotas portfelis bus sudaromas remiantis Markowitz (1952, 1959 ) portfelio teorija. Laukiamas atskirų vertybiniu popieriu pelningumas bus lygus jų grąžos vidurkiui analizuotu 2007-04-10 - 2011-02-10 laikotarpiu, rizika - grąžos standartiniam nuokrypiui minètu laikotarpiu.

Portfelio tikètinas pelningumas yra lygus $\mathfrak{i}$ portfelio sudèti itrauktų priemonių tikètinų pelningumų vidurkiui:

$$
E\left(R_{p}\right)=\sum_{i=1}^{n} w_{i} E\left(R_{i}\right)
$$

čia $E\left(R_{p}\right)$ - tikètina portfelio grąža; $w_{i}$ - investicijų dalis, investuota $i$ i vertybini popierių; $E\left(R_{i}\right)$ - i vertybinio popieriaus tikètinas pelningumas (grąža); n vertybinių popierių skaičius portfelyje.

Portfelio rizika yra matuojama naudojant portfelio planuojamo pelningumo standartinį nuokrypi:

$$
\sigma_{p}=\left[\sum_{i=1}^{N} \sum_{j=1}^{M} w_{i} w_{j} \operatorname{COV}\left(R_{i} R_{j}\right)\right]^{1 / 2},
$$

čia $\operatorname{COV}\left(R_{i} R_{j}\right)$ - kovariacija tarp i ir j finansinių priemonių grąžos.

Iš viso sudaroma 10 investiciju portfelių - 9 Markowitz efektyvūs investicijų portfeliai ir 1 lyginamasis, kuriame visi 24 BPF turi lygius svorius. Portfelių pelningumo rizikos kombinacijos pateikiamos 1.7 paveiksle. 


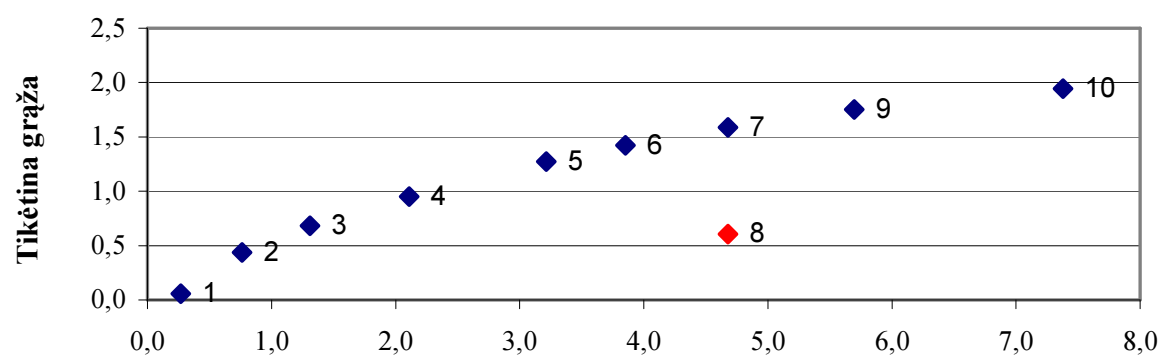

Rizika (standartinis nuokrypis)

1.7 pav. Sudarytų portfelių pelningumo ir rizikos kombinacijos

Fig. 1.7. Return-risk trade-offs of selected portfolios'

Šaltinis: sudaryta autoriaus

Portfelių grąža ir rizika, bei aktyvų deriniai portfeliuose pateikiami B priede. Iš 1.7 paveikslo ir B priedo matyti, jog 7-o ir 8-o portfelių rizikos lygiai vienodi, tačiau 7-o (Markowitz optimalaus) portfelio tikètina grąža yra žymiai didesnè nei 8-o (lyginamojo) portfelio. Taip pat reikia pastebèti, kad 8 iš nagrinètų BPF nebuvo įtraukti į nei vieną optimalų investicijų portfelị: 4 akcijų (FEZ, SPY, GUR, GAF), 1 obligacijų (BLV), 2 valiutų (FXC, FXM), 1 prekių (DBA), o didžiausios rizikos portfeliuose didžiausią svorị turi tauriujjų metalų aukso ir sidabro BPF. Vidutinis optimalių portfelių rizikos ir laukiamos grąžos santykis yra lygus 2,87 ir yra 2,7 karto mažesnis nei lyginamojo portfelio, taip pat mažesnis nei visų, išskyrus trumpalaikių obligacijų, pavienių BPF analogiškus rodiklius. Portfelių, sudarytų pasirinktomis proporcijomis, „ex post“ rezultatų vertinimas (portfelių vertès kitimas 2007-04-10 - 2011-02-10 laikotarpiu pateikiamas $\mathrm{C}$ priede) parodo, jog net aštuonių iš pasirinktų devynių optimalių portfelių vertès nebuvo mažesnès nei pradinè investicijų suma, nors investavus i minètus portfelius prieš pat finansų krizès piką investicijų vertè sumažejo žemiausiame taške iki 30 proc. investicijų vertès.

\subsubsection{Portfelių rezultatų ivertinimas}

Ankstesniame poskyryje buvo sudaryti investicijų portfeliai ir ivertinta jų elgsena krizès ir atsigavimo po jos laikotarpiu, tačiau praeities duomenų analizè negali užtikrinti efektyvumo ateityje, todèl reikia įvertinti portfelių rezultatus po analizuoto laikotarpio (nuo portfelio sudarymo momento). Pažymètina, kad nuo 2011-02-10 įvyko nemažai svarbių ìvykių ir sukrètimų, turejjusių itakos finansų rinkoms (Europos skolų krizè, konfliktai Šiaurès Afrikoje, cunamis ir 
branduolinė krizė Japonijoje, sankcijos Iranui ir pan.). Taigi šis laikotarpis yra tinkamas plačiai diversifikuoto portfelio elgsenai padidejusio rinkų nepastovumo sąlygomis parodyti.

D priede pateikti kasdieniai portfelių vertès svyravimai 2011-02-10-201204-10 parodo, jog tik dviejų portfelių verte nagrinètu laikotarpiu buvo mažesnè nei pradinių investicijų suma - mažiausios rizikos portfelio ir lyginamojo portfelio, sudaryto lygiomis dalimis iš visų analizuotų aktyvų. D priedas taip pat parodo, jog per analizuotą laikotarpi optimizuotų portfelių verte labai svyravo. Detali informacija apie portfelių rezultatus kiekvieną analizuoto laikotarpio mėnesị ir ménesinès grąžos vidurkiai per visą analizuotą laikotarpi yra pateikti 1.7 lentelèje.

1.7 lentelè. Mènesinès portfelių grąžos, $\%$

Table 1.7. Monthly returns of portfolios, $\%$

\begin{tabular}{|c|c|c|c|c|c|c|c|c|c|c|}
\hline Laikotarpis & 1 & 2 & 3 & 4 & 5 & 6 & 7 & 8 & 9 & 10 \\
\hline $02-10-03-10$ & $-0,25$ & 0,45 & 0,76 & 1,11 & 1,78 & 2,33 & 2,92 & 1,40 & 5,99 & 10,82 \\
\hline $03-10-04-11$ & $-0,05$ & $-0,35$ & 0,00 & 0,60 & 1,71 & 2,73 & 3,83 & 4,17 & 6,26 & 9,66 \\
\hline $04-11-05-10$ & 0,00 & 1,17 & 1,59 & 2,29 & 2,95 & 2,71 & 2,47 & $-0,52$ & 1,04 & $-1,13$ \\
\hline $05-10-06-10$ & $-0,10$ & 0,17 & 0,16 & $-0,04$ & $-0,11$ & $-0,10$ & $-0,10$ & $-1,95$ & $-1,25$ & $-3,15$ \\
\hline $06-10-07-11$ & $-0,03$ & 0,61 & 0,84 & 0,95 & 0,91 & 1,18 & 1,46 & $-0,12$ & 1,00 & 0,12 \\
\hline $07-11-08-10$ & 0,10 & 1,56 & 2,74 & 4,29 & 6,17 & 7,76 & 9,45 & $-4,13$ & 11,10 & 12,35 \\
\hline $08-10-09-12$ & 0,44 & 0,92 & 1,02 & 1,10 & 0,76 & 1,09 & 1,42 & 1,20 & 1,51 & 1,54 \\
\hline $09-12-10-10$ & $-0,49$ & $-1,44$ & $-2,15$ & $-2,91$ & $-3,85$ & $-5,28$ & $-6,73$ & $-3,72$ & $-9,99$ & $-14,49$ \\
\hline $10-10-11-10$ & 0,00 & 0,93 & 1,52 & 1,95 & 2,59 & 3,69 & 4,86 & 1,96 & 5,25 & 5,43 \\
\hline $11-10-12-12$ & $-0,22$ & $-0,44$ & $-1,12$ & $-1,98$ & $-3,07$ & $-3,93$ & $-4,82$ & $-2,64$ & $-5,68$ & $-6,72$ \\
\hline $12-12-01-10$ & $-0,14$ & 0,23 & 0,26 & 0,42 & 0,13 & $-0,42$ & $-1,01$ & 1,34 & $-2,03$ & $-3,42$ \\
\hline $01-10-02-10$ & $-0,15$ & 0,36 & 1,03 & 1,81 & 3,02 & 4,18 & 5,40 & 3,91 & 6,76 & 8,65 \\
\hline $02-10-03-12$ & $-0,32$ & $-0,60$ & $-1,37$ & $-2,36$ & $-2,99$ & $-2,23$ & $-1,44$ & 0,52 & $-0,93$ & $-0,41$ \\
\hline $03-12-04-10$ & $-0,21$ & $-0,32$ & $-0,45$ & $-0,62$ & $-0,86$ & $-1,60$ & $-2,35$ & $-2,47$ & $-3,11$ & $-4,09$ \\
\hline Gražos vidurkis & $-\mathbf{0 , 1 0}$ & $\mathbf{0 , 2 3}$ & $\mathbf{0 , 3 5}$ & $\mathbf{0 , 4 7}$ & $\mathbf{0 , 6 5}$ & $\mathbf{0 , 8 6}$ & $\mathbf{1 , 1 0}$ & $\mathbf{- 0 , 0 8}$ & $\mathbf{1 , 1 4}$ & $\mathbf{1 , 0 8}$ \\
\hline Tikètina grq̌̆a & $\mathbf{0 , 0 6}$ & $\mathbf{0 , 4 4}$ & $\mathbf{0 , 6 8}$ & $\mathbf{0 , 9 5}$ & $\mathbf{1 , 2 7}$ & $\mathbf{1 , 4 2}$ & $\mathbf{1 , 5 9}$ & $\mathbf{0 , 6 1}$ & $\mathbf{1 , 7 5}$ & $\mathbf{1 , 9 4}$ \\
\hline
\end{tabular}

Šaltinis: sudaryta autoriaus

1.7 lentelè parodo, jog nei vienam iš sudarytų portfelių nepavyko pasiekti tikètinos grąžos lygio, tačiau matyti akivaizdus ryšys tarp optimizuotų portfelių tikètino ir realiai gauto pelningumo. Taigi, kaip buvo parodyta 1.6 paveiksle, diversifikavimas investuojant skirtingose rinkose gali sumažinti investicijų vienoje rinkoje sisteminę rizika, tačiau neleidžia visiškai eliminuoti sisteminès rizikos, o mažesnę nei tikètiną grąžą galèjo nulemti bendri visoms investicijų rinkoms veiksniai. 
Plačiai diversifikuoto portfelio sudarymo tema buvo analizuota siekiant ivertinti pasyvaus investuotojo apsisaugojimo nuo rizikos galimybes rinkų neapibrezžtumo laikotarpiu. Tai reikalauja ivvertinti investuotojų faktiškai patirtą riziką portfelių efektyvumo testavimo laikotarpiu. Sudarant portfeli rizikai vertinti buvo naudotas tradicinis jos vertinimo būdas - standartinis nuokrypis nuo vidutinès grąžos. Kadangi rizika yra laikomas bet koks nuokrypis nuo tikètino rezultato, rizikai vertinti tikslinga taikyti ne standartini nuokrypi nuo vidutinès grąžos (nes tokiu atveju investicijos, dèl kurių patiriama pastovaus dydžio nuostolių, būtų prilygintos nerizikingoms investicijoms), o standartini nuokrypi nuo numatytos tikètinos investicijų grąžos (SNTG), kuris apskaičiuojamas analogiškai šaknies iš vidutinès kvadratinès paklaidos skaičiavimui vertinant prognozavimo tikslumą. Šiuo atveju investuotojo patiriamai rizikai apskaičiuoti bus taikoma formulè:

$$
S N T G=\sqrt{\frac{\sum_{t=1}^{n}\left(R_{t}-E(R)_{t}\right)^{2}}{n} .}
$$

Kiekvieno portfelio faktinis rizikos lygis 2011-02-10-2012-04-10 bei rizikos ir vidutinès grąžos santykiai yra pateikiami 1.8 lenteleje.

1.8 lentelè. Portfelių rizika

Table 1.8. Risk of the portfolios

\begin{tabular}{|c|c|c|c|c|c|c|c|c|c|c|}
\hline \multirow{2}{*}{ Rodiklis } & \multicolumn{10}{|c|}{ Portfelis } \\
\cline { 2 - 12 } & 1 & 2 & 3 & 4 & 5 & 6 & 7 & 8 & 9 & 10 \\
\hline SNTG & 0,27 & 0,80 & 1,30 & 1,95 & 2,72 & 3,37 & 4,13 & 2,63 & 5,42 & 7,36 \\
\hline SD & 0,21 & 0,77 & 1,26 & 1,89 & 2,65 & 3,32 & 4,10 & 2,53 & 5,39 & 7,31 \\
\hline SNTG/R & $-2,58$ & 3,44 & 3,77 & 4,11 & 4,16 & 3,90 & 3,77 & $-33,95$ & 4,77 & 6,79 \\
\hline SD/R & $-2,04$ & 3,32 & 3,64 & 3,98 & 4,05 & 3,85 & 3,74 & $-32,77$ & 4,74 & 6,74 \\
\hline
\end{tabular}

Šaltinis: sudaryta autoriaus

Duomenys, pateikti 1.8 lenteleje, parodo, kad faktinè portfelių rizika tik dviem iš nagrinètų atvejų (dviejų mažiausios rizikos portfeliu atveju) buvo didesnè, nei buvo vertinama portfelio sudarymo metu, tačiau mažesnis, nei tikètasi, pelningumas lèmé, kad pablogèjo rizikos, tenkančios vienam grąžos vienetui, rodiklis. Dèl mažesnio, nei tikètasi, pelningumo, pasiūlyto standartinio nuokrypio nuo tikètinos grąžos (SNTG) kaip rizikos mato reikšmės yra didesnès nei paprasto standartinio nuokrypio, nes atspindi ne tik gražos svyravimus, bet ir jos nuokrypius nuo investuotojo lūkesčių. 


\subsection{Pirmojo skyriaus išvados}

Nepaisant duomenų trūkumo tyrimo reprezentatyvumui ir gautų rezultatų patikimumui užtikrinti šis pilotinis plataus investicijų portfelio sudarymo galimybių tyrimas leidžia pateikti tokias išvadas ir apibendrinimus:

1. Didejjanti investicinių priemonių ívairovè suteikia net privatiems, smulkiems investuotojams plačias investicijų galimybes, leidžiančias gauti pelno iš valiutų kursų, nekilnojamojo turto ar prekių ir išteklių kainų kitimo.

2. Atlikta atskirų aktyvų kainų kitimus reprezentuojančių BPF grąžu koreliacinè analizè parodè, jog 2007-04-10-2011-02-10 akcijų BPF grąžos buvo labai koreliuotos (mažiausias koreliacijos koeficientas 0,77 ), tačiau dalis valiutų ir prekių BPF turèjo labai mažas ar net neigiamas koreliacijas, tai leidžia teigti, jog i tradicinių investicinių priemonių (akcijų ir obligacijų) portfeli itraukus valiutas ir prekes galima pasiekti didesni diversifikacijos lygi.

3. Nedidelès ir neigiamos koreliacijos globalios finansų krizès laikotarpiu leidžia teigti, jog sisteminè vienos (pvz., akcijų) rinkos rizika gali būti sumažinta investuojant keliose skirtingose investicijų rinkose.

4. Sudaryto Markowitz optimalaus portfelio, kurio rizika yra lygi lyginamojo portfelio, sudaryto iš visų BPF lygiomis dalimis, rizikai, laukiama grąža yra beveik trigubai didesnè nei lyginamojo portfelio, tai parodo, jog portfelio optimizavimo nauda yra didesnè esant didesniam aktyvų skaičiui ir mažesnėms jų tarpusavio koreliacijoms.

5. Optimizuotų portfelių rezultatai testavimo laikotarpiu buvo prastesni nei analizuotu ,ex post“ laikotarpiu, tačiau visi, išskyrus mažiausios rizikos portfeli, užtikrino geresnę nei lyginamojo portfelio grąžą.

6. Realiai patirtai rizikai, kaip faktinès grąžos neatitikimo laukiamai grąžai, tinkamai ịvertinti buvo pasiūlytas standartinio nuokrypio nuo tikètinos gražos (SNTG) metodas, kuris parodè, jog testuojamu laikotarpiu tik du mažiausios rizikos portfeliai patyrè didesnę, nei buvo ịvertinta portfelio sudarymo metu, riziką.

7. Didžiausios rizikos portfelius sudaro vos 2-3 aktyvai, tai reiškia, kad pasikeitus situacijai rinkoje didžiausios rizikos portfeliai galètų neužtikrinti efektyvios diversifikacijos.

8. Esant trumpesniam sudarytų portfelių efektyvumo testavimo laikotarpiui, kuris buvo taikytas Žilinskij, Kuzminskas (2011), visų, išskyrus mažiausios rizikos, optimizuotų portfelių rezultatai viršijo jų laukiamą pelninguma, tai reiškia, kad ilgejant laikotarpiui nuo portfelio sudarymo momento, jo atitiktis investuotojo poreikiams gali mažeti, taigi net plačiai diversifikuojant portfeli tikslinga būti ne pasyviam investuotojui, o periodiškai peržiūrèti portfelio sudèti, iš naujo ỉvertinti esamų BPF charakteristikas ir 
galimybes itraukti naujus aktyvus, kurių nebuvo galima itraukti sudarant pirminị plačiai diversifikuotą investicijų portfeli. 


\section{2}

\section{Portfelio sprendimai aktyviems investuotojams}

Ankstesniame skyriuje nagrinètos pasyvaus investuotojo rizikos minimizavimo galimybès sudarant plačiai diversifikuotą investicijų portfeli, tačiau dalis investuotojų nesirinks plačiai diversifikuoto portfelio, o aktyviai valdys mažiau diversifikuotą portfeli. Tam yra kelios priežastys: dalis investuotojų nori tiksliai žinoti, i ką investuoja, o pvz., BPF yra nuo realių investicinių objektų nutolusi investicinè priemonė; plačiai diversifikuoti portfeliai ilguoju laikotarpiu negalès užtikrinti pakankamos grąžos rizikuoti linkusiems investuotojams. Tačiau, ko gero, svarbiausias veiksnys, nulemiantis aktyvaus portfelio valdymo pasirinkima, yra galimybe savarankiškai priimti sprendimus, užtikrinanti žmogaus tobulëjimą, jo asmenybès vystymąsi, nuolat ieškant strategijų ir taktikų, leidžiančių pasinaudoti rinkų dinamikos galimybėmis. Šiame skyriuje išanalizuoti efektyviosios portfelio ribos pokyčiai aktyviai valdant investicijų portfeli taikant finansini sverta, pasiūlytas prognozių integravimo metodas prognozavimo tikslumui didinti bei sprendimo keisti portfelio sudèti prièmimo metodas. Šiame skyriuje atliktos analizès pagrindu parengti straipsniai laiko eilučių prognozių integravimo (Žilinskij 2012) ir finansinio sverto taikymo aktyviai valdant investicijų portfeli (Rutkauskas, Žilinskij 2010) temomis. 


\subsection{Efektyviosios portfelių ribos modeliavimas}

Techninè pažanga, naujos prognozavimo priemonès ir programos bei didejantis rinkų nepastovumas verčia investuotojus vis dažniau rinktis aktyvų investicijų portfelio valdymą. Aktyvaus investicijų portfelio valdymo galimybes išplečia finansinio sverto taikymo galimybès, t. y. galimybè daryti didžiausias investicijas $\mathfrak{i}$ rizikingus aktyvus, kai numatomas jų kainų augimas, ir rinktis nerizikingas investicijas numatomo rinkų smukimo laikotarpiu. Tačiau aktyvus portfelio valdymas panaudojant finansini svertą turi papildomų apribojimų ir sąnaudų, kurių neịvertina bazinè modernioji portfelio teorija ir kurie gali turèti reikšmingą itaką investavimo rezultatams. Anot Jurevičienès ir Klimavičienès (2008), svarbu sukurti tokị matematiškai pagrịstą asmeninių finansų valdymo (iskaitant investicijų valdyma) modeli, kuris savo parametrais atspindétu realybę. Taigi netikslus visų apribojimų ir sąnaudų ịvertinimas gali klaidinti investuotojus.

\subsubsection{Mokslinių darbų efektyviosios ribos modeliavimo tematika analizè}

Šiame darbe jau minèta, jog moderniosios portfelio teorijos pradininku laikomas H. Markowitz (1952, 1959), kuris savo darbuose pavartojo terminus tiketinas portfelio pelningumas, portfelio rizika, portfelio diversifikavimas ir efektyvusis portfelis.

Remiantis H. Markowitz portfelio teorija, investuotojas, priimdamas sprendimą pasirinkti portfelio sudeti, siekia maksimizuoti laukiamą portfelio pelningumą ir minimizuoti riziką.

H. Markowitz portfelio teorija leidžia nustatyti efektyviaja portfelio ribą (plačiau apie efektyviosios ribos nustatymą Markowitz 1952, 1959), kuri leis minimizuoti riziką esant tam tikram pelningumui arba maksimizuoti pelną esant konkrečiam rizikos lygiui.

Taigi efektyviają portfeliu aibę sudarys portfeliai, kurie 2.1 paveiksle labiausiai nutolę i kairę ir ị viršų (kitaip sakant, portfeliai, esantys kreivèje $A B$ ). Investuotojas, remdamasis savo polinkiu rizikuoti ir abejingumo kreive, turetu rinktis portfelius, kurių rizikos ir pelningumo kombinacijas vaizduoja efektyvioji riba (C taškas 2.2 pav.). 


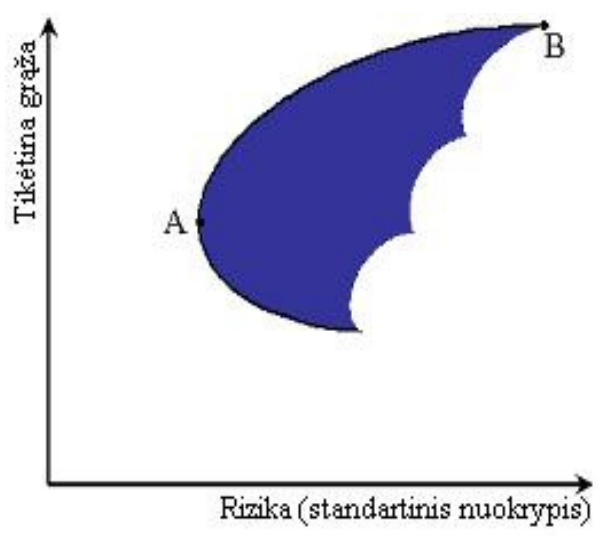

2.1 pav. Efektyvioji portfelių riba Fig. 2.1. Efficient set of portfolios Šaltinis: Rutkauskas, Žilinskij (2010)

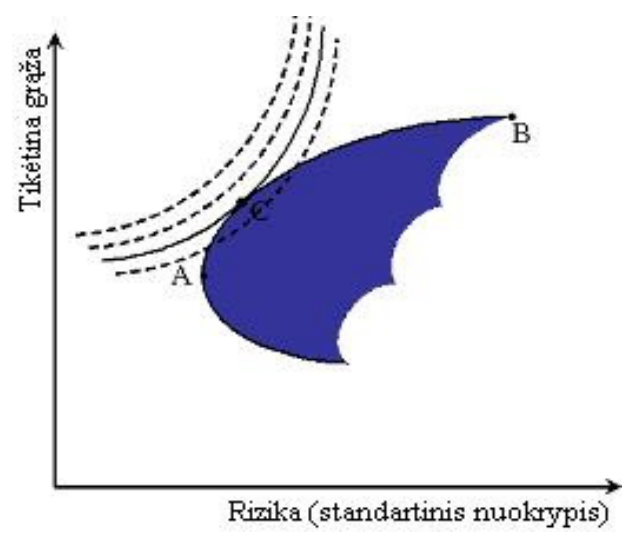

2.2 pav. Optimalaus portfelio pasirinkimas

Fig. 2.2. Optimal portfolio selection Šaltinis: Rutkauskas, Žilinskij (2010)

Nors daugelio mokslininkų moderniosios portfelio teorijos pradininku yra laikomas H. Markowitz, tačiau, kaip pripažino pats Markowitz (1999), šią garbę jis turètų po lygiai pasidalinti su kitu, literatūroje gerokai rečiau minimu mokslininku A. D. Roy.

Pagrindinis Roy (1952) ir Markowitz (1952) teorijų skirtumas yra tai, jog Markowitz teorija leidžia nustatyti efektyviaja portfelių ribę, o Roy įvedè naują kintamaji - minimalią reikalaujamą grąža, kuris leido pasirinkti konkretų portfeli iš efektyviosios ribos, t.y. vienareikšmiškai spręsti portfelio pasirinkimo problema. Konkretus portfelis sudaromas pasirenkant portfelio sudèti, kuri maksimizuotų perteklinès grąžos ir rizikos santyki (Roy 1952):

$$
\max \frac{m-d}{\sigma},
$$

čia $\mathrm{m}$ - tikètina grąža; $d$ - minimali investuotojo reikalaujama grąža; $\sigma$ standartinè paklaida.

Vertinant investicijų portfelio teorijos raidą sunku nepastebėti panašumų tarp Roy (1952) pavaizduotos efektyviosios ribos liestinès ir Sharpe (1964) pasiūlyto kapitalo aktyvų ikainojimo modelio (kapitalo rinkos tiesès (CML)) pateikto 2.3 ir 2.4 paveiksluose. 


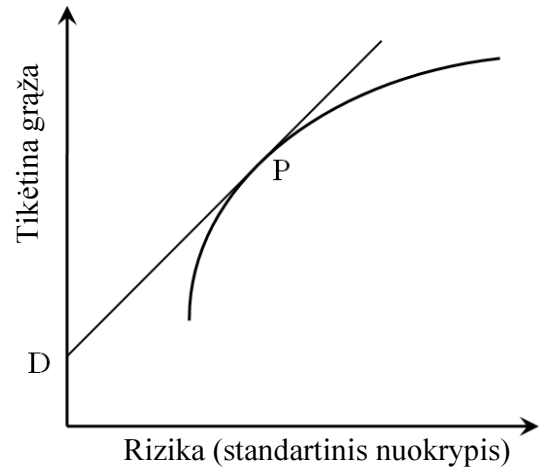

2.3 pav. Efektyviosios ribos liestinè

Fig. 2.3. Tangent of efficient set Šaltinis: Sudaryta autoriaus remiantis Roy (1952)

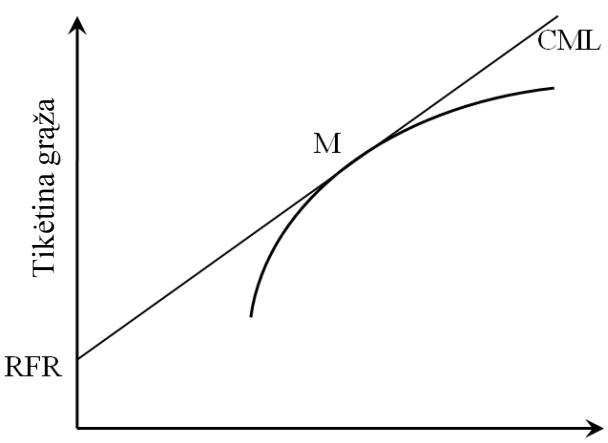

Rizika (standartinis nuokrypis) 2.4 pav. Kapitalo rinkos tiesé

Fig. 2.4. Capital market line Šaltinis: Sudaryta autoriaus remiantis Sharpe (1964)

Iš 2.3 ir 2.4 paveikslų matyti, kad jie yra beveik identiški. Pagrindinis skirtumas tarp Roy ir Sharpe darbų yra tai, jog Roy pasiūlè naudoti ne nerizikingą palūkanų norma, o minimalią investuotojo reikalaujamą grąža, t. y. remiantis Roy (1952) teorija yra pasirenkamas geriausiai investuotojo poreikius atitinkantis vien rizikingų aktyvų portfelis, o remiantis Sharpe (1964) teorija, yra tik vienas optimalus visiems investuotojams rizikingu aktyvu portfelis, o investuotojai reikalaujamą grąžos ir rizikos santyki pasiekia papildomai pasiskolindami ar skolindami (investuodami) už nerizikinga palūkanų normą. Kapitalo rinkos tiesé pasidaro efektyviaja portfelių riba ir investuotojai turi pasirinkti efektyviosios ribos taška, i kokị rizikingų ir nerizikingų aktyvų derinį investuos.

J. Tobin atskyre investavimo ir finansavimo sprendimus ir tai pavadino atskyrimo teorema - investuotojas visų pirma priima sprendimą investuoti i portfeli M 2.4 paveiksle (priima investavimo sprendima), vèliau, remdamasis rizikos tolerancija, investuotojas priima finansavimo sprendimą - paskolinti ar pasiskolinti už nerizikingą palūkanų normą siekiant norimo rizikos lygio (Jones 1991). Skirtingų investuotojų priimamus sprendimus galima pavaizduoti grafiškai (2.5 pav.).

Iš 2.5 paveikslo matyti, jog portfeliu pasirinkimas iš kapitalo rinkos tiesès leidžia investuotojams pasiekti geresni pelno - rizikos santyki (parodytą taškuose A ir B) negu Markowitz (1952) ir Roy (1952) teorijų atveju, tačiau turi daugiau apribojimų ir remiasi didesniu prielaidų, i kurias turi būti atsižvelgta ivertinant realias rizikos - pelningumo kombinacijas, skaičiumi. 


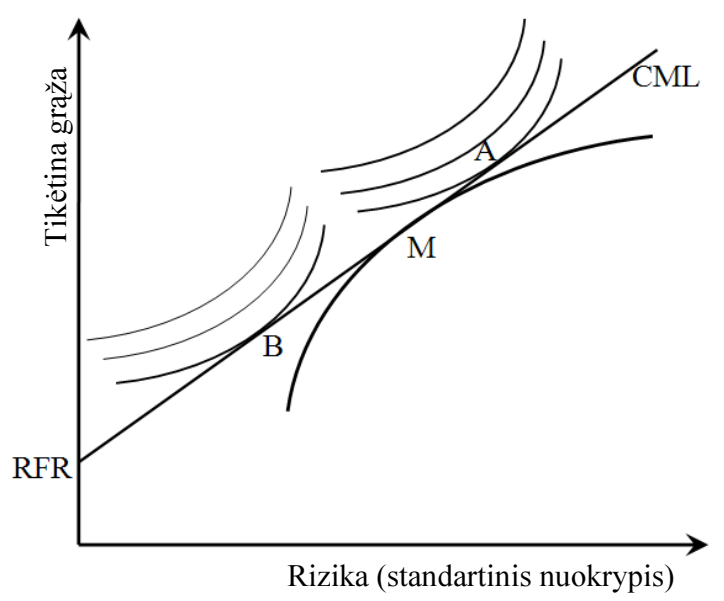

2.5 pav. Finansavimo sprendimo priemimas

Fig. 2.5. Acceptance of the financing decision Šaltinis: Rutkauskas, Žilinskij (2010)

Vienas iš pagrindinių ir dažniausiai literatūroje analizuojamų apribojimų, kuris turi itakos portfelių rizikos - grąžos kombinacijoms yra skirtingos nerizikingo skolinimosi ir skolinimo palūkanų normos, jų poveikis portfelio rizikos ir pelningumo kombinacijoms buvo analizuotas Sharpe (1963) ir daugelio kitų mokslininkų (Olson, Bley 2008; Painter 2011; Hai-xiang, Zhongfei 2009; Sadjadi et al. 2011; Fu et al. 2010). Efektyvioji portfeliu riba esant skirtingoms skolinimo ir skolinimosi palūkanų normoms yra pateikta 2.6 paveiksle.

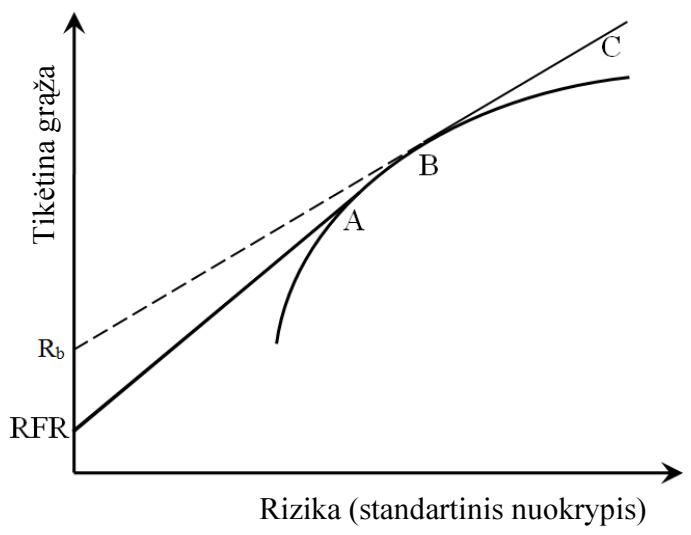

2.6 pav. Efektyvioji portfelių riba esant skirtingoms skolinimo ir skolinimosi kainoms

Fig. 2.6. Efficient set of portfolios given different lending and borrowing costs Šaltinis: Rutkauskas, Žilinskij (2010) 
2.6 paveiksle RFR parodo nerizikingo skolinimo, o $R_{b}$ nerizikingo skolinimosi palūkanų normas, o efektyvioji portfelio riba yra kreivè RFRABC, kur RFRA tiesè parodo investavimo galimybes (rizikos grąžos kombinacijas) derinant nerizikingas ir rizikingas investicijas portfelyje, lankas $\mathrm{AB}$ - efektyvius portfelius investuojant vien $\mathfrak{i}$ rizikingus aktyvus, tiesé $\mathrm{BC}-$ kai papildomai skolinamasi siekiant daugiau, nei turima, lèšų investuoti i rizikingų aktyvų portfeli.

Mokslinejje literatūroje daug dèmesio skiriama sandorių sąnaudoms ịvertinti (Kissel et al. 2004; Kozhan, Schmid 2009; Dai, Yi 2009; Jana et al. 2009; Bertsimas, Pachamanova 2008; Feng et al. 2011; Krejic et al. 2011), tačiau didžioji jų dalis (Dai, Yi 2009; Jana et al. 2009; Bertsimas, Pachamanova 2008; Feng et al. 2011; Krejic et al. 2011) yra nukreipta į matematinį sandorių sąnaudu ivertinimo problemos sprendimą ir tik keliuose darbuose yra vertinama rizikos ir sandoriu sąnaudu priklausomybė (Kissel et al. 2004) ir parodomas sąnaudu poveikis laukiamiems rezultatams (Kozhan, Schmid 2009). Taip pat vertinamas portfelio optimizavimas esant minimalios sandorių apimties apribojimui (Soleimani et al. 2009), tačiau neparodomas šių veiksnių poveikis efektyviajai portfelių ribai.

\subsubsection{Efektyviosios portfelių ribos modeliavimas aktyviai valdant investiciju portfeli}

Aktyvus portfelio valdymas, ypač panaudojant finansini sverta, turi dar daugiau apribojimų, kurie nagrinètuose mokslininkų darbuose nèra ịvertinti modeliuojant efektyviaja portfeliu ribą. Aktyviai valdant portfeli ir naudojant pažangias laukiamo pelningumo ir rizikos prognozavimo technikas ir programas, atskirais laikotarpiais bus skirtingos efektyviosios portfeliu ribos, todèl investuotojui teks dažnai keisti nerizikingų aktyvų kieki portfelyje (vieną kartą skolintis, kitą kartą skolinti, žr. CML1 ir CML2 2.7 paveiksle.), todèl reikia ivertinti dažno nerizikingo skolinimo ir skolinimosi trumpam laikotarpiui galimybes.

Vertinant nerizikingo skolinimo/skolinimosi galimybes Lietuvoje, reikia pastebèti, jog pats paprasčiausias nerizikingo skolinimo būdas yra indèlis smulkieji investuotojai gali juo naudotis, jei peržiūri savo portfelio sudèti ne dažniau kaip kartą per savaitę, o stambūs investuotojai turi galimybę skolinti lěšas ir vienai dienai. Daug sudètingiau yra skolintis. Prielaida, jog investuotojai gali pasiskolinti ar paskolinti bet kokị pinigu kiekị esant nerizikingai pelno normai nèra tinkama, kadangi skolinimo ir skolinimosi pelno normos skiriasi. Pasiskolinti labai greitai ir trumpam laikotarpiui bet kokị pinigu kieki neįmanoma. Atsižvelgiant ì tai, jog investuotojui sprendimus tenka priimti 


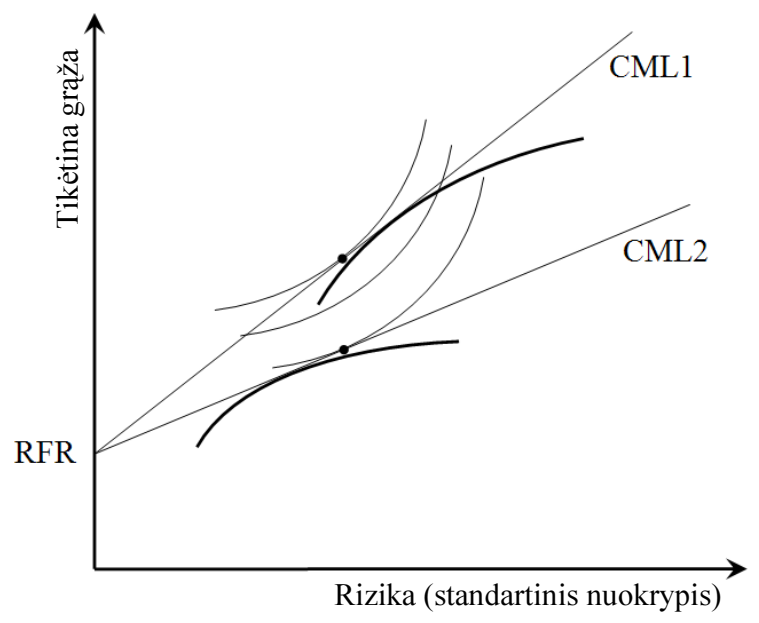

2.7 pav. Galimos efektyvumo ribos skirtingais laikotarpiais

Fig. 2.7. Potential efficient sets during various periods

Šaltinis: Rutkauskas, Žilinskij (2010)

nedelsiant, Lietuvos sąlygomis skolinimosi galimybe galima laikyti kreditinès kortelès issigijimą arba kredito linijos sutarties sudarymą. Šie du atvejai nesuteikia neriboto skolinimosi galimybès (negalima viršyti limito) ir reikia mokèti fiksuotą mokesti vien tik už skolinimosi galimybès turejjimą, nepriklausomai nuo to, ar ji yra naudojama. Dèl ribotos maksimalios galimos pasiskolinti sumos kapitalo rinkos tiesè nèra neribota, o dèl fiksuotų mokesčių pati tiesè ir efektyvumo riba pasislenka ì apačią ( 2.8 pav.).

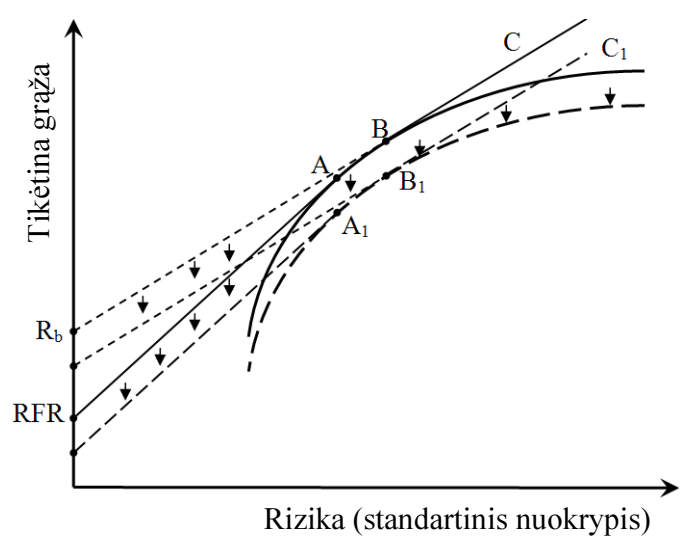

2.8 pav. Fiksuotų mokesčiu poveikis rizikos-pelningumo kombinacijoms

Fig. 2.8. Impact of the fixed taxes on the risk-profitability combinations Šaltinis: Rutkauskas, Žilinskij (2010) 
Didelę itaką aktyviai valdomo portfelio rezultatams turi sandorių sąnaudos. Proporcinès (procentinès) sandorių sąnaudos gali būti ịvertintos mažinant laukiamą i portfelio sudèti itraukiamų vertybinių popierių pelningumą:

$$
E\left(R_{i}\right)^{\prime}=E\left(R_{i}\right)-O C,
$$

čia $E\left(R_{i}\right)^{\prime}$ - laukiamas pelningumas įvertinus proporcines sandorių sąnaudas; $E\left(R_{i}\right)$ - laukiamas pelningumas neįvertinus sąnaudų; OC - sandorių sąnaudos (proc.).

Siekiant visiškai parodyti finansinių veiksnių poveiki modelyje, taip pat reikia ivertinti modelio netikslumus, susijusius su tuo, jog isigyjant labai nedidelị kiekị rizikingų investicijų yra taikomas fiksuotas sandorių ikainis ir yra minimalūs indèlių (nerizikingo skolinimo) limitai. Visų minètų veiksnių itraukimas i modeli yra pateikiamas 2.9 paveiksle, kur plona linija parodyta bazinè efektyvioji portfelių riba, o paryškinta linija - efektyvioji riba, pakoreguota, atsižvelgiant $\mathfrak{i}$ išvardintus realios rinkos apribojimus (skirtingas skolinimo/skolinimosi palūkanų normas, operacijų sąnaudas, naudojimosi finansiniu svertu galimybę ir minimalią nerizikingo skolinimo suma).

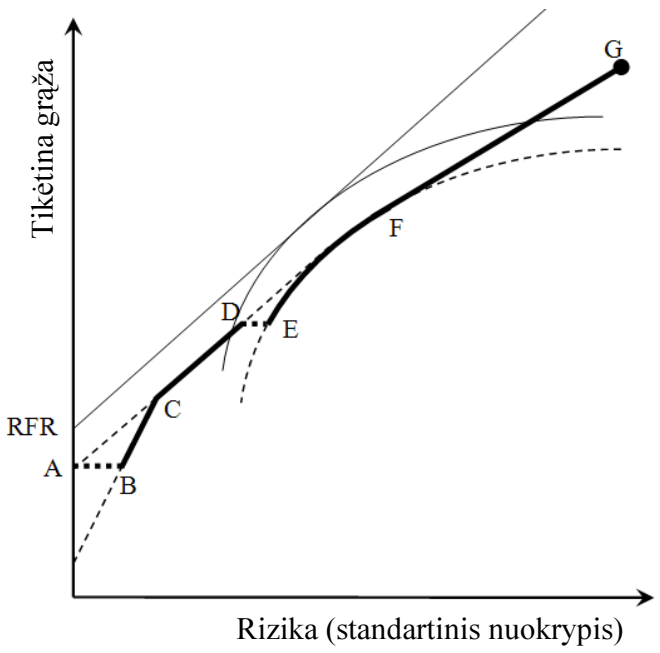

2.9 pav. Koreguota efektyvioji portfelių riba

Fig. 2.9. Correction of the efficient set of portfolios Šaltinis: Rutkauskas, Žilinskij (2010)

2.9 paveikslas parodo, kad įvertinus visus apribojimus ir atsirandančias papildomas išlaidas, kurias realiai patirtų investuotojas, aktyviai valdydamas investicijų portfelị ir nerizikingai skolindamas(is), šis portfelio valdymo būdas, lyginant su H. Markowitz modeliu, būtų naudingas tik tuo atveju, jei 
investuotojas per visą laikotarpi intensyviai naudotųsi skolinimo ar skolinimosi galimybėmis.

\subsubsection{Aktyvaus portfelio valdymo taikant finansini svertą tikslingumo empirinis tyrimas}

Efektyviosios portfeliu ribos modeliavimas leido nustatyti, kad aktyvus portfelio valdymas panaudojant finansini svertą gali būti naudingas tik tuo atveju, jei bus aktyviai naudojamasi nerizikingo skolinimo ir (ar) skolinimosi galimybėmis. Mažos nerizikingo investavimo ir skolinimosi sumos neleis gauti didesnio pelno, negu pasirenkant Roy ar Markowitz efektyvuji portfeli. Nerizikingo skolinimo(si) galimybių panaudojimo intensyvumą tikslinga panagrinèti sudarant investicijų portfeli. Tyrimas atliekamas analizuojant portfelio sudarymo galimybes iš didžiausias akciju prekybos apyvartas 2011 metais turejjusių (likvidžiausių) bendrovių, kotiruojamų Vilniaus vertybinių popieriu biržos oficialiame sąraše. Analizei pasirenkamas 2011-01-05 - 201203-07 laikotarpis. Kadangi minètu laikotarpiu „Sanito“ akcijų kainos kitimas buvo labai iškreiptas dèl planuojamo įmonès pasitraukimo iš rinkos ir jau kuris laikas prekyba šios įmonès akcijoms nèra aktyvi, šios bendrovès akcijos nebus itrauktos i tyrimą.

Tyrimui atrinktos šios aštuonios bendrovès: $A P B$ „Apranga“ (APG); $A B$ „City service“ (CTS); AB „Invalda“ (IVL); AB „Linas Agro Group“(LNA); AB Panevėžio statybos trestas (PTR); AB Siaulių bankas (SAB); AB TEO LT (TEO); AB Ūkio bankas (UKB).

Atsižvelgiant i tai, kad empirinis tyrimas atliekamas siekiant ivertinti skolinimo/skolinimosi galimybių panaudojimo intensyvumą ir finansinio sverto panaudojimo tikslinguma, o ne realiai investuoti ir vertinti investavimo rezultatus, kiekvienos akcijos laukiamas pelningumas bus ivertinamas kaip praejusių laikotarpių pelningumų vidurkis, o rizika bus vertinama kaip pelningumo standartinis nuokrypis nuo vidurkio. Siekiant pavaizduoti pelningumo ir rizikos svyravimus skirtingais laikotarpiais ivertinamas praeities duomenų kiekis turi būti pakankamas, kad galima būtų įvertinti akcijų grąžos tarpusavio kovariacijas, bet ne per didelis, nes tai sumažintų laukiamos grąžos ir rizikos svyravimus skirtingais laikotarpiais. Šiame tyrime planuojamas pelningumas ir rizika bus ivertinami, remiantis penkių praeities laikotarpių duomenimis: planuojamas pelningumas yra lygus penkių praejusių laikotarpių pelningumų vidurkiui, rizika lygi standartiniam penkių praejusių laikotarpių pelningumų nuokrypiui nuo vidurkio. Portfelio sudètis keičiama vienos savaitès periodiškumu.

Turint planuojamus kiekvienos priemonès pelningumus, bendras portfelio laukiamas pelningumas yra apskaičiuojamas kaip svertinis i portfeli jeinančiu 
priemonių laukiamų pelningumų vidurkis. Vidutinis standartinis nuokrypis apskaičiuojamas pagal šio darbo 1 skyriuje pateiktą 1.2 formulę.

Nerizikinga pelno norma, priklausomai nuo to, ar investuotojas planuoja skolintis, kad galètų daugiau investuoti i vertybinius popierius, ar mažiau investuoti ir dali pinigu skolinti, yra atitinkamai skolinimosi ir skolinimo palūkanų normos. Atsižvelgiant i tai, kad investuotojas skolina(si) labai trumpam laikotarpiui, šiame tyrime taikoma skolinimosi palūkanų norma yra 12,5 proc. per metus $(\approx 0,24$ proc. per savaitę), nerizikingo skolinimo palūkanų norma -2 proc. per metus $(\approx 0,04$ proc. per savaitę).

Investuotojas, svarstydamas galimybę skolintis arba skolinti už nerizikingą palūkanų normą, atsižvelgia ị investicijų riziką ir savo rizikos tolerancijos lygị. Rizikos tolerancijos lygis priklauso nuo kiekvieno investuotojo. Šiame tyrime yra daroma prielaida, kad kiekvienu laikotarpiu investuotojas priima sprendimą maksimizuoti pelningumą su sąlyga, kad investicijų rizika nebus didesnè, negu lyginamojo portfelio, sudaryto lygiomis dalimis iš visų analizuojamų akcijų, rizika.

Remiantis anksčiau išvardintomis prielaidomis ir aprašytais tyrimo atlikimo principais, kiekvienam investicijų periodui galima sudaryti po optimalų rizikingų vertybinių popierių (minètų bendrovių akcijų) portfelį. Portfelių laukiamas kiekvieno periodo pelningumas ir rizika, tai pat finansinio sverto panaudojimo intensyvumas pateikiami 2.1 lenteleje (portfelių sudetis pateikiama E priede).

2.1 lentelè. Portfelių laukiamas pelningumas ir rizika

Table 2.1. Expected portfolios' return and risk

\begin{tabular}{|c|c|c|c|c|c|}
\hline \multirow{2}{*}{ Periodas } & \multicolumn{2}{|c|}{ Aktyviai valdomas } & \multicolumn{2}{c|}{ Lyginamasis portfelis } & \multirow{2}{*}{$\begin{array}{c}\text { Skolinimas (-) } \\
\text { Skolinimasis (+) }\end{array}$} \\
\cline { 2 - 5 } & Grǎža & Rizika & Grǎža & Rizika & $-17 \%$ \\
\hline 1 & 1,65 & 2,79 & 0,66 & 2,32 & $-25 \%$ \\
\hline 2 & 1,32 & 3,14 & 0,50 & 2,37 & $12 \%$ \\
\hline 3 & 1,06 & 2,24 & 0,14 & 2,50 & $45 \%$ \\
\hline 4 & 2,14 & 1,44 & 0,49 & 2,09 & $-29 \%$ \\
\hline 5 & 1,01 & 2,64 & $-0,26$ & 1,88 & $-100 \%$ \\
\hline 6 & 0,00 & 0,00 & $-2,03$ & 1,75 & $-100 \%$ \\
\hline 7 & 0,00 & 0,00 & $-1,30$ & 2,74 & $-100 \%$ \\
\hline 8 & 0,00 & 0,00 & $-1,15$ & 2,74 & $70 \%$ \\
\hline 9 & 0,38 & 1,38 & $-1,24$ & 2,76 & $3 \%$ \\
\hline 10 & 0,28 & 2,68 & $-1,15$ & 2,77 & $15 \%$ \\
\hline 11 & 0,97 & 1,53 & 0,02 & 1,76 & $-100 \%$ \\
\hline 12 & 0,00 & 0,00 & $-0,66$ & 0,78 & $-100 \%$ \\
\hline 13 & 0,00 & 0,00 & $-0,57$ & 0,80 & $-51 \%$ \\
\hline 14 & 0,52 & 2,60 & $-0,82$ & 1,26 & $-52 \%$ \\
\hline 15 & 0,36 & 2,67 & $-0,74$ & 1,28 & \\
\hline
\end{tabular}


2.1 lentelès pabaiga

\begin{tabular}{|c|c|c|c|c|c|}
\hline \multirow[b]{2}{*}{ Periodas } & \multicolumn{2}{|c|}{ Aktyviai valdomas } & \multicolumn{2}{|c|}{ Palyginamasis portfelis } & \multirow{2}{*}{$\begin{array}{c}\text { Skolinimas (-) } \\
\text { Skolinimasis (+) }\end{array}$} \\
\hline & Grąža & Rizika & Grąža & Rizika & \\
\hline 16 & 1,59 & 3,69 & $-0,19$ & 2,03 & $-45 \%$ \\
\hline 17 & 1,23 & 1,84 & $-0,17$ & 2,03 & $10 \%$ \\
\hline 18 & 3,01 & 8,10 & $-0,04$ & 2,03 & $-75 \%$ \\
\hline 19 & 0,38 & 0,00 & 0,73 & 1,27 & $70 \%$ \\
\hline 20 & 0,82 & 0,00 & 1,08 & 1,15 & $70 \%$ \\
\hline 21 & 0,68 & 0,31 & 0,39 & 0,60 & $70 \%$ \\
\hline 22 & 2,39 & 0,51 & 0,69 & 0,64 & $26 \%$ \\
\hline 23 & 2,10 & 1,83 & 0,48 & 0,85 & $-54 \%$ \\
\hline 24 & 2,13 & 2,40 & 0,19 & 0,99 & $-59 \%$ \\
\hline 25 & 1,02 & 1,76 & $-0,02$ & 0,81 & $-54 \%$ \\
\hline 26 & 1,53 & 2,67 & $-0,40$ & 1,19 & $-55 \%$ \\
\hline 27 & 0,00 & 0,00 & $-2,82$ & 4,03 & $-100 \%$ \\
\hline 28 & 0,00 & 0,00 & $-2,36$ & 4,37 & $-100 \%$ \\
\hline 29 & 0,00 & 0,00 & $-2,95$ & 4,32 & $-100 \%$ \\
\hline 30 & 0,00 & 0,00 & $-2,30$ & 4,96 & $-100 \%$ \\
\hline 31 & 0,13 & 7,55 & $-2,52$ & 4,97 & $-34 \%$ \\
\hline 32 & 0,47 & 3,00 & $-0,99$ & 3,00 & $0 \%$ \\
\hline 33 & 0,15 & 6,41 & $-1,68$ & 2,70 & $-58 \%$ \\
\hline 34 & 0,73 & 1,25 & $-1,18$ & 2,48 & $70 \%$ \\
\hline 35 & 1,04 & 1,43 & $-2,85$ & 1,21 & $-15 \%$ \\
\hline 36 & 2,72 & 3,68 & $-0,97$ & 3,74 & $2 \%$ \\
\hline 37 & 3,13 & 3,36 & $-0,15$ & 3,65 & $9 \%$ \\
\hline 38 & 4,85 & 3,38 & 0,56 & 3,59 & $6 \%$ \\
\hline 39 & 2,57 & 3,47 & 1,03 & 3,47 & $0 \%$ \\
\hline 40 & 2,50 & 0,72 & 1,94 & 2,18 & $70 \%$ \\
\hline 41 & 1,04 & 0,14 & 0,76 & 0,67 & $70 \%$ \\
\hline 42 & 0,00 & 0,00 & $-1,57$ & 4,56 & $-100 \%$ \\
\hline 43 & 0,00 & 0,00 & $-1,33$ & 4,56 & $-100 \%$ \\
\hline 44 & 0,00 & 0,00 & $-1,62$ & 4,64 & $-100 \%$ \\
\hline 45 & 0,00 & 0,00 & $-2,60$ & 4,76 & $-100 \%$ \\
\hline 46 & 0,00 & 0,00 & $-2,34$ & 4,93 & $-100 \%$ \\
\hline 47 & 0,98 & 3,04 & 0,26 & 2,90 & $-4 \%$ \\
\hline 48 & 0,77 & 2,56 & $-0,17$ & 2,63 & $3 \%$ \\
\hline 49 & 0,81 & 1,71 & 0,38 & 2,80 & $64 \%$ \\
\hline 50 & 1,76 & 0,00 & 1,73 & 0,61 & $70 \%$ \\
\hline 51 & 1,78 & 1,54 & 0,96 & 1,76 & $15 \%$ \\
\hline 52 & 1,48 & 1,64 & 0,76 & 1,64 & $0 \%$ \\
\hline 53 & 3,43 & 2,94 & 1,57 & 2,30 & $-22 \%$ \\
\hline 54 & 1,14 & 1,38 & 0,96 & 2,42 & $70 \%$ \\
\hline 55 & 1,47 & 2,49 & 0,45 & 2,49 & $0 \%$ \\
\hline 56 & 0,90 & 0,64 & 0,77 & 2,19 & $70 \%$ \\
\hline
\end{tabular}

Šaltinis: sudaryta autoriaus 
Iš 2.1 lentelèje pateiktų duomenų matyti, jog optimizuoto portfelio laukiamas pelningumas yra didesnis už lyginamojo portfelio tikètiną pelninguma, o rizika būna didesnè arba mažesnè. Tarkime, investuotojas turi ribotas skolinimosi galimybes ir prireikus gali pasiskolinti ne daugiau kaip 70 procentų nuosavų investuojamų lèšu sumos. Paskutinèje lentelès skiltyje yra nurodyta: su minuso ženklu - kiek procentų turimų lěšų investuotojas skolins už nerizikingą palūkanų normą; teigiamas skaičius - kiek procentų nuo investuojamų lèšų sumos papildomai pasiskolins ir investuos i rizikingus vertybinius popierius.

Vertinant gautus rezultatus privataus (smulkaus) investuotojo atžvilgiu, reikia pastebèti, kad skolinti už nerizikingą palūkanų normą jis galètų tik tuo atveju, jei skolinama suma būtų didesnè už banko nustatytą privalomą minimumą. Tai reiškia, kad tuo atveju, kai įsigijus vertybinius popierius lieka tik, pavyzdžiui, 1 procentas nerizikingoms investicijoms, pinigai nebus investuojami, o investuotojas pats turès priimti sprendima, ar: 1) investuoti visas lěšas i kiek mažesnès rizikos vertybinių popieriu portfeli; 2) prisiimti kiek didesnę investicijų riziką; 3 ) investuoti i pasirinktą portfelį ne visą sumą, o likutị palikti visai neinvestuotą. Darant prielaidą, kad skolinti už nerizikingą palūkanų normą galima ne mažiau kaip 5 procentus turimų lèšu, galima pastebèti, jog 2.1 lenteleje yra tik vienas toks atvejis.

Bendras nerizikingo skolinimo/skolinimosi naudojimas atsispindi 2.10 paveiksle.

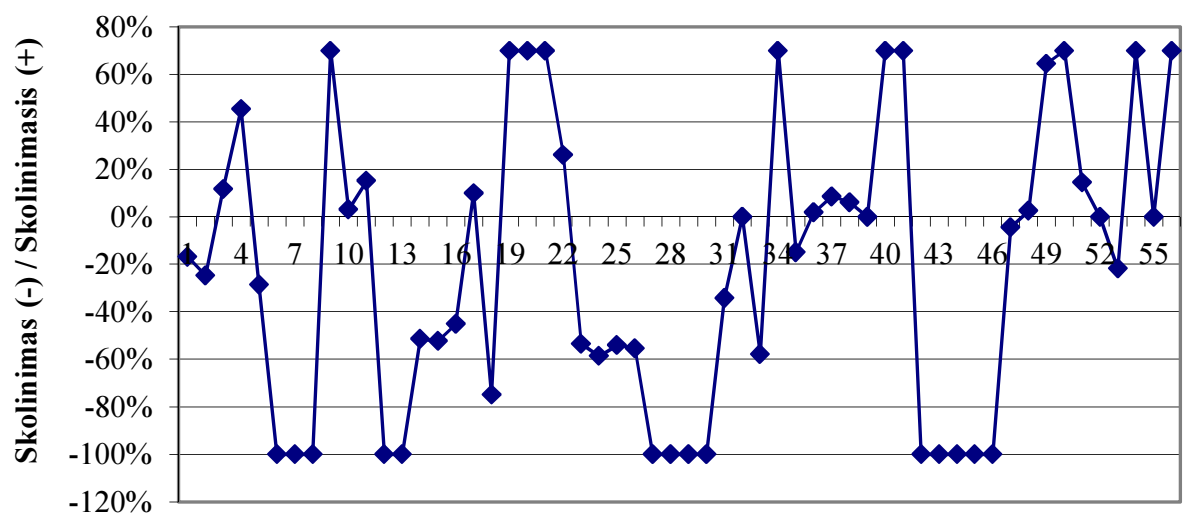

Investavimo periodas

2.10 pav. Skolinimo/skolinimosi galimybių panaudojimo intensyvumas

Fig. 2.10. Intensity of usage of lending/borrowing possibilities Šaltinis: sudaryta autoriaus 
Apibendrinant 2.1 lenteleje ir 2.10 paveiksle pateiktą informaciją reikia pastebèti, kad:

1. 14 iš nagrinètų atvejų bus investuojama vien tik į nerizikingus vertybinius popierius (taškas A 2.9 paveiksle), t. y. laukiamas kiekvieno rizikingo vertybinio popieriaus pelningumas yra mažesnis už nerizikinga palūkanų norma:

2. 15 iš nagrinètų atvejų bus investuojama derinant rizikingų vertybinių popieriu issigijimą ir nerizikingas investicijas (linija BCD 2.9 paveiksle), darant prielaida, jog investuoti $\mathfrak{i}$ vertybinius popierius ir daryti nerizikingas investicijas galima ir apsimoka, kai nerizikingoms investicijoms skiriama ne mažiau nei 5 proc. turimų lèšų;

3. 4 iš nagrinètu atvejų visa turima suma bus investuojama i rizikingus vertybinius popierius (kreivè EF 2.9 paveiksle);

4. 22 iš nagrinètu atvejų visa turima suma bus investuojama i rizikingus vertybinius popierius ir papildomai bus pasiskolinama lèšu investicijoms (tiesė FG 2.9 paveiksle); iš jų net 10 atvejų, kai bus skolinamasi maksimali galima suma (taškas $\mathrm{G} 2.9$ paveiksle).

Vertinant siūlomo modelio taikymo efektyvuma, reikia pastebèti, jog per visą nagrinejamą laikotarpi skolindamas už nerizikingą palūkanų normą investuotojas gautų 0,79 proc. grąžos. Šis skaičius nèra didelis, bet įvertinant tai, jog nerizikingos investicijos (skolinimas) nereikalauja papildomų sąnaudų, esant ilgesnio laikotarpio laukiamam akcijų kainų nuosmukiui ir didesnèms investicijų sumoms, tokias investicijas daryti verta. Nerizikingas investavimas taip pat yra apsauga nuo investicijų vertès sumažèjimo krentant rizikingo turto vertei.

Esant 2.1 lenteleje pateiktoms grąžos ir rizikos kombinacijoms, papildomai skolinantis investicijoms neviršijant lyginamojo portfelio rizikos galima padidinti laukiamą investicijų pelningumą 10,65 proc., o skolinimosi sąnaudos esant tokiam skolinimosi intensyvumui investicijų pelningumą sumažina tik apie 2,19 proc. per nagrinètą laikotarpi (lyginant reikia pastebèti, jog analogiško Rutkauskas, Žilinskij (2010) atlikto tyrimo 2008-11-2009-12 laikotarpiu rezultatai buvo atitinkamai 66,7 ir 10 proc.). Tai leidžia teigti, jog tikintis 2.1 lenteleje pateikto aktyviai valdomo portfelio pelningumo, skolintis ir investuoti $i$ rizikingus vertybinius popierius yra verta.

Apibendrinant atlikto tyrimo rezultatus, būtina pastebèti, kad tyrimas išryškino vieną pasiūlyto modelio netikslumą - esant ribotoms skolinimosi galimybėms, optimalus rizikingu vertybiniu popieriu portfelis ne visuomet yra tas, kuris garantuoja rizikos ir pelningumo kombinacija, 2.6 paveiksle pavaizduotą taške B. Ši netikslumą galima pavaizduoti grafiškai (2.11 pav.). 


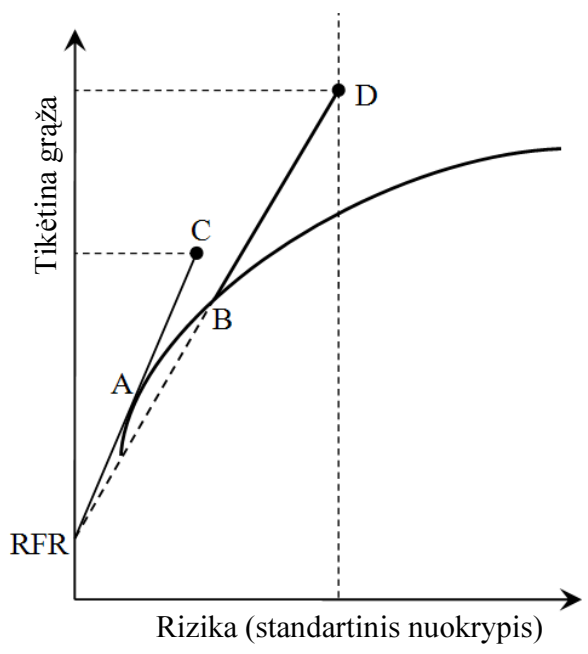

2.11 pav. Modelio patikslinimas

Fig. 2.11. Adjustment of a model

Šaltinis: Rutkauskas, Žilinskij (2010)

Iš 2.11 paveikslo matyti, kad investuotojas priimdamas sprendimą investuoti i rizikingų vertybinių popieriu portfelį, pavaizduotą taške $B$, neperžengdamas maksimalios toleruojamos rizikos ribos (vertikali brūkšninė linija), gali pasiekti daug didesni pelninguma, negu investuodamas i portfeli, pavaizduotą taške A. Atsižvelgiant $i$ tai, bendra aktyviai valdomo portfelio naudojant finansinį svertą efektyviosios ribos forma igyja vaizda, parodytą 2.12 paveiksle.

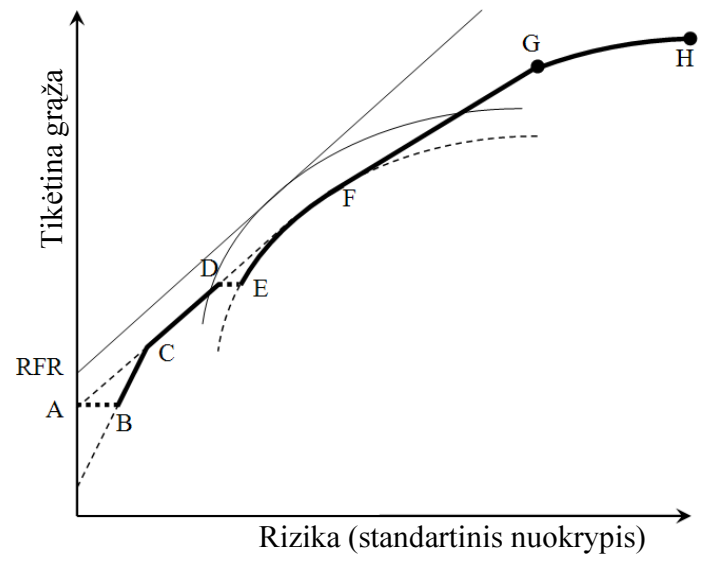

2.12 pav. Efektyvioji riba naudojant ribotą finansinị svertą

Fig. 2.12. Efficient set using a limited financial leverage Šaltinis: Rutkauskas, Žilinskij (2010) 
Reikia pažymèti, kad teorinejje dalyje minèta investavimo ir finansavimo sprendimų atskyrimo teorema turètų būti išplèsta. Investuotojas, aktyviai valdydamas portfelį taikant finansini sverta, sprendimų prièmimą turi išskaidyti $\mathfrak{i}$ tris pakopas: preliminaraus investavimo sprendimo prièmimą - taško A radimą (2.11 pav.); finansavimo sprendimo priemima; investavimo sprendimo patikslinimą (jei patikslinimas leidžia padidinti pelningumą neviršijant rizikos tolerancijos lygio). Apibendrinta sprendimu prièmimo schema pateikiama 2.13 paveiksle.

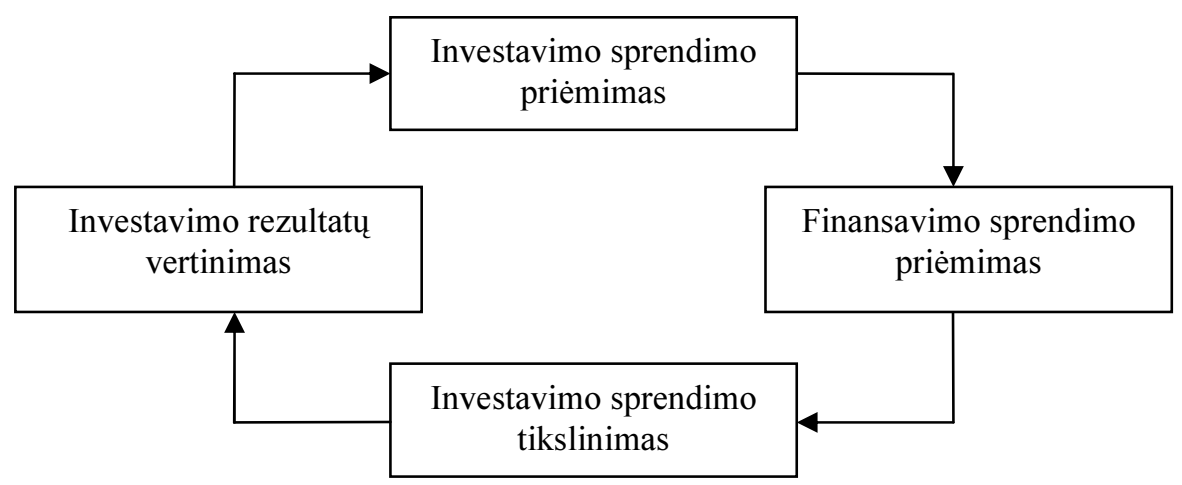

2.13 pav. Apibendrinta sprendimų priemimo schema

Fig 2.13. Framework for decision making Šaltinis: sudaryta autoriaus

2.13 paveikslas parodo, jog prièmus minètus sprendimus (nustačius optimalią rizikingų aktyvų sudètị ir nerizikingo skolinimo - skolinimosi lygi) yra sudaromas investiciju portfelis, o įvertinus investavimo rezultatus gaunama informacija naujiems sprendimams priimti (ciklui kartoti).

\subsection{Prognozavimo tikslumo didinimas integruojant skirtingais metodais gautas prognozes}

Ankstesniame šio skyriaus poskyryje buvo parodyta, jog aktyvus portfelio valdymas naudojant finansini svertą gali būti efektyvi priemonè siekiant padidinti investicijų grąžą. Tačiau aktyviai valdant portfelị ženkliai padidèja portfelio valdymo sąnaudos. Vienas iš pagrindinių veiksnių, galinčių užtikrinti efektyvų portfelio valdyma, yra galimybe gauti kuo tikslesnes akcijų grąžos prognozes. Akcijų grąžai prognozuoti taikoma daug skirtingų metodų, nuo paprasčiausių (pvz., slankiujų vidurkių) iki sudètingų (pvz., neuroniniai tinklai, genetiniai algoritmai ir pan.). Viena populiariausių prognozavimo metodų grupių 
yra laiko eilučiu analizè, todèl šiame darbe, kuriant prognozių integravimo metoda, tyrimas bus nukreiptas i skirtingu periodų laiko eilučių prognozių integravimą, tačiau bendrasis integravimo principas bus sudaromas taip, kad galètų būti naudojamas ir kitais būdais gautoms prognozèms integruoti.

Investuotojui, siekiančiam aktyviai valdyti investiciju portfeli, svarbu yra turèti tikslias trumpo laikotarpio prognozes (pvz. vienai prekybos dienai $\mathfrak{i}$ prieki), tad akivaizdu, kad prognozuodamas laukiamą pelningumą investuotojas didesni prioritetą teiks naujausių duomenų analizei - vertins dieninius akcijų kainų pokyčius pastaraisiais laikotarpiais ir mažiau kreips dèmesi i ilgo laikotarpio (pvz., metinius) kainų pokyčius. Tačiau finansų krizè ir finansų rinkų atsigavimas po jos parode, kad kuo didesnis yra trumpo ir vidutinio laikotarpio akcijų kainų nuosmukis, tuo didesnis būna akcijų kainų augimas po jo, o vien trumpalaikių duomenų analize ir bendrų (ilgalaikių) akcijų kainos kitimo tendencijų neįvertinimas gali suklaidinti investuotojus. Taigi efektyvus skirtingų periodų laiko eilučių prognozių integravimas gali užtikrinti tiek trumpalaikių, tiek ilgalaikių tendencijų ivvertinimą prognozuojant akcijų grąžą.

\subsubsection{Laukiamo pelningumo ivertinimo problemos ištirtumo lygis}

Moderniosios portfelio teorijos pradininkai Roy ir Markowitz tiksliai neapibrèžè, kaip turètų būti ịvertinamas laukiamas pelningumas, ir tik Markowitz (1952) užsiminè, kad galbūt yra būdų suformuoti pagrisstas tikimybines viltis integruojant statistines technikas ir ekspertų vertinimus. Atlikdamas empirini tyrima, Markowitz (1959) laukiamam pelningumui nustatyti taikè aritmetini vidurki, kuris vèliau buvo taikomas ir daugelio kitu mokslininku (pvz., Tvaronavičienè, Michailova 2004; Vasiliauskaitė 2004; Bikas, Laurinavičius 2009; Baixauli-Soler 2011). Bernstein ir Wilkinson (1997), Eaker ir Grant (2002), Willenbrock (2011) suabejojo aritmetinio vidurkio tinkamumu ir pasiūlè taikyti geometrini vidurkị. Missiakoulis et al. (2010) ne tik ivertino aritmetinio ir geometrinio vidurkių taikymo galimybes, bet ir pasiūlè juos integruoti skaičiuojant logaritmini ir identrini vidurkius. Gilli ir Kellezi (2000) pasiūlè taikyti scenarijų metodą laukiamam pelningumui vertinti.

Atskira laukiamo pelningumo ivvertinimo metodu grupe yra slankieji vidurkiai. Edwards ir Magee (1992) skiria 4 pagrindines slankiujų vidurkių metodu grupes: paprastasis slankusis vidurkis (SMA), svertinis slankusis vidurkis (WMA), eksponentinis slankusis vidurkis (EMA) ir linijinis slankusis vidurkis. Dzikevičius ir Šaranda (2010) taiko EMA ir SMA metodus akcijų kainai prognozuoti. Autoregresinis slankusis vidurkis (ARMA) ir jo modifikacijos (MARMA, ARIMA, SARIMA) taip pat taikomi akciju grąžai prognozuoti (Sallehuddin et al. 2007; Stevenson 2007; Jarret, Schilling 2008). 
Akciju gražai prognozuoti gali būti taikomi tokie sudètingi prognozavimo metodai, kaip dirbtiniai neuroniniai tinklai (ANN), paslepptasis Markovo modelis (HMM), genetiniai algoritmai ir pan. Dirbtinių neuroninių tinklų panaudojimą akcijų kainai prognozuoti analizavo Stern (1996), Kumar (2010), Leigh et al. (2002), Panda ir Narasimhan (2010), Jandaghi (2010). Paslèptojo Markovo modelio taikymo akcijų kainai prognozuoti galimybes nagrinejjo Hassan ir Nath (2005), Erlwein et al. (2012). Araujo (2010) prognozavimui taiko QIEHI (quantum-inspired evolutionary hybrid intelligent) požiūri. Li ir Tsang (1999) pasiūlè naudoti genetini programavimą techninès analizès prognozèms gerinti.

Mokslinejje literatūroje taip pat daugelyje darbų siūloma integruoti atskirus prognozavimo metodus. Chou et al. (1997) sukūre akcijų pasirinkimo paramos sistemą, sujungiančią dirbtini intelektą ir techninę analizę. Zhang et al. (2008) taikè akcijų rinkos prognozavimo modeli, sujungianti autoregresini slankuji vidurkị ir paramos vektorių mašinas. Nenortaite ir Simutis (2006) pasiūlè atskirų dirbtinių neuroninių tinklų (ANN) integravimą naudojant dalelių masės optimizavimo (Particle Swarm optimization - PSO) algoritmą geriausiam ANN atrinkti ir kitu ANN svoriams, palyginus su geriausio ANN svoriu, nustatyti. Lu et al. (2011) aprašè integruotą akcijų indeksų prognozavimo metodą, sujungiantị nelinijinès nepriklausomų komponentų analizès (NLICA), paramos vektorių regresijos (SVR) ir dalelių masès optimizavimo (PSO) metodus. Mehdi ir Mehdi (2011), Sallehuddin et al. (2007) nuomone, reikètu derinti nelinijini ir linijini programavimą integruotame ANN-ARIMA modelyje. Erlwein et al. (2011) modeliavo finansines laiko eilutes panaudodami paslèptojo Markovo modeli ir geometrini Browno judejimą (GBM). Hassan et al. (2007) pasiūlè integruotą HMM-ANN-GA modeli akcijų kainoms prognozuoti. Afolabi ir Olude (2007) sukūrè HCSOM (Hybrid Cohonen Self Organising Map) metodą, kuris išplètė iprastą neuronini tinklą pridedamas papildomą neuronų lygi, kuriame tolesnei analizei atrenkami geriausi metodai.

Atlikta mokslinių darbų prognozavimo tematika analizè parodé, jog yra daugelis akcijų grąžos prognozavimų metodu̧, tiek paprastų tiek sudètingų, mokslininkai taip pat teikia atskirų metodų integravimo pasiūlymus, tačiau dažniausiai siūlomas atskirų metodų, o ne naudojant juos gautų prognozių, integravimas, kuris turi vieną esmini trūkumą - jei investuotojas neturi pakankamai duomenų ar žinių bent vienam iš integruojamų metodų pritaikyti, jis negalès pasinaudoti siūlomu integruotu metodu. Šis ribotumas galètu būti išspręstas tik integruojant ne pačius prognozavimo metodus, o juos taikant gautas prognozes, tačiau šiai sričiai mokslininkų darbuose skiriama mažiau dèmesio. Prie prognozių integravimo būtų galima iš dalies priskirti Afolabi ir Olude (2007) pasiūlytą HCSOM metodą (2.14 pav.). 


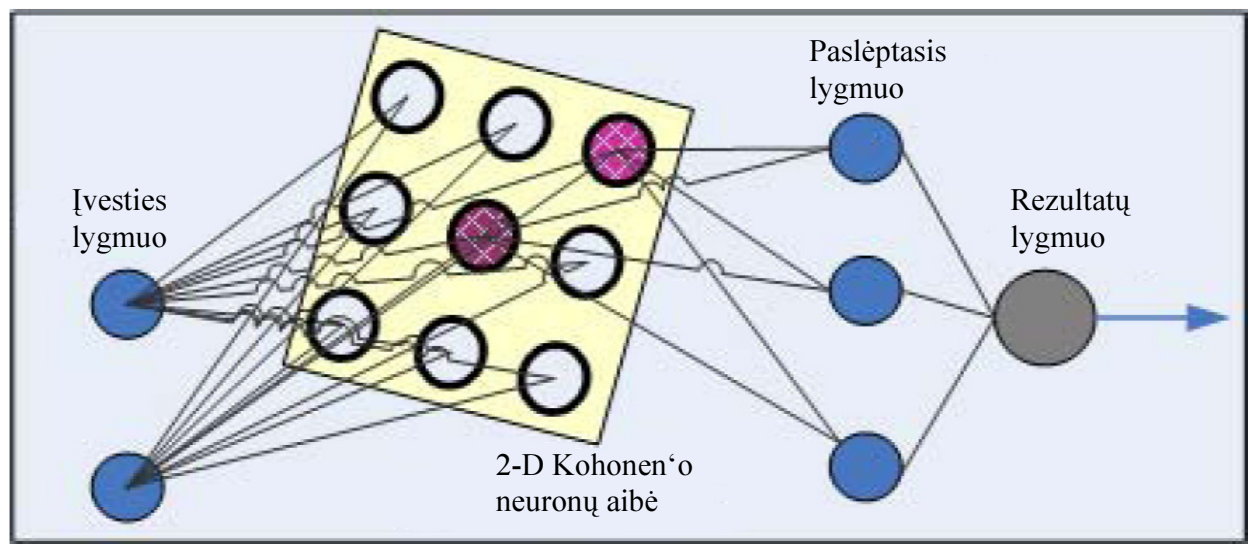

2.14 pav. HCSOM modelis

Fig. 2.14. HCSOM model

Šaltinis: Afolabi, Olude (2007)

Iš 2.14 paveikslo matyti, kad tuo atveju, jei papildomame neuronu lygmenyje būtų atskirais prognozavimo metodais gautos prognozès, tuomet šis modelis atitiktų prognozių integravimo metodo sąvoka, tačiau ir tuo atveju šis modelis turètų trūkumą - tolesnei analizei atrenkamos tik geriausios prognozès visiškai neįvertinant mažiau tikslių prognozių, galinčių turèti įtakos prognozavimo tikslumui.

Naujausioje mokslineje literatūroje pavyko rasti tik vieną darba, kuriame prognozès integruojamos. Ustun ir Kasimbeyli (2012) pasiūlè prognozių integravimo modeli, paremtą vidutine absoliutine prognozavimo paklaida, pagal kurị prognozès yra integruojamos minimizuojant funkciją:

$$
M_{i F E_{i}} \min \sum_{i=1}^{T} \sum_{k=1}^{M} \lambda_{i k}\left|\varepsilon_{i t k}\right| / T,
$$

kai: $\sum_{1=k}^{M} \lambda_{i k}=1, \quad \lambda_{i k} \geq 0, \quad k=1,2, \ldots, M$;

čia: $\varepsilon_{i t k}-\mathrm{k}$ metodo $\mathrm{i}$ akcijos prognozavimo paklaida laikotarpiu t, kur $\mathrm{k}=1,2, \ldots \mathrm{M}, \mathrm{t}=1,2, \ldots, \mathrm{T}, \mathrm{i}=1,2, \ldots, \mathrm{N} ; \lambda_{i k}-\mathrm{i}$ akcijos $\mathrm{k}$ prognozės svoris.

Šis metodas turi du trūkumus. Visų pirma, jis tiksliai neapibrèžia, kokiomis proporcijomis turetų būti paskirstomi svoriai atskiroms prognozėms ir investuotojai turi savarankiškai minimizuoti tikslo funkciją. Antras šio metodo trūkumas yra tai, jog taikant 2.3 formulę prognozavimo paklaida yra vertinama absoliučiu dydžiu, o integruojant prognozes svarbus ne tik paklaidos dydis, bet ir tai, ì kurią pusę yra nuokrypis. 


\subsubsection{Prognozių integravimo metodo sukūrimas}

Šio poskyrio ižangoje buvo minèta, kad prognozių integravimo metodas bus kuriamas ir bandomas integruojant skirtingo periodo laiko eilučiu prognozes. Skirtingo periodo laiko eilučių prognozių integravimo principas yra parodytas 2.15 pav.

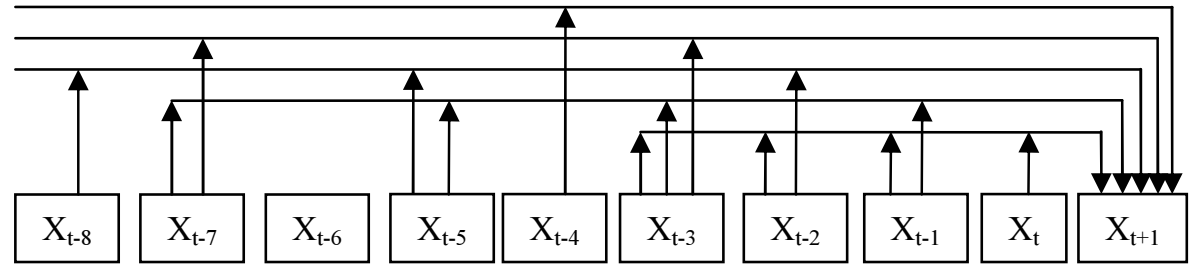

2.15 pav. Skirtingo periodo laiko eilučių integravimas

Fig. 2.15. Different period time series forecasts integration Šaltinis: sudaryta autoriaus

$\mathrm{X}_{\mathrm{t}} 2.15$ paveiksle parodo akcijos gražą $\mathrm{t}$ laikotarpiu, kur $\mathrm{t}$ yra paskutinis laikotarpis, kurio duomenys turimi. $\mathrm{X}_{\mathrm{t}+1}$ - grąžos prognozė artimiausiam ateities laikotarpiui.

Skirtingo periodo laiko eilučių integravimo metodo analitinè išraiška susideda iš dviejų dalių:

1) skirtingo periodo laiko eilučių prognozių nustatymo:

$$
\begin{aligned}
& X_{t+1}^{1}=f\left(X_{t} ; X_{t-1} ; X_{t-2} ; \ldots ; X_{t-n}\right) \\
& X_{t+1}^{2}=f\left(X_{t-1} ; X_{t-3} ; X_{t-5} ; \ldots ; X_{t-2 n-1}\right) \\
& X_{t+1}^{3}=f\left(X_{t-2} ; X_{t-5} ; X_{t-8} ; \ldots ; X_{t-3 n-2}\right) \\
& \ldots \\
& X_{t+1}^{k}=f\left(X_{t-k+1} ; X_{t-2 k+1} ; X_{t-3 k+1} ; \ldots ; X_{t-k n-k+1}\right)
\end{aligned}
$$

2) gautų prognozių integravimo į bendrą įvertị (galutinę prognozę):

$$
X_{t+1}=f\left(X_{t+1}^{1} ; X_{t+1}^{2} ; X_{t+1}^{3} ; \ldots ; X_{t+1}^{k 1}\right) .
$$

Metodas, susidedantis iš dviejų dalių, reikalauja skirtingų sprendimų atskirais jo igyvendinimo etapais. Siekiant nustatyti skirtingo periodo laiko eilučiu prognozes galima naudoti paprastus ar net integruotus šio poskyrio teorinejje dalyje nagrinètus laiko eilučių analizès metodus. Kiekvienas investuotojas gali pats pasirinkti, kuri metodą naudos. 
Kad skirtingų periodų laiko eilučiu prognozavimo metodas efektyviai funkcionuotu, daug svarbiau yra užtikrinti tinkamus sprendimus antroje jo igyvendinimo stadijoje - integruojant prognozes i bendrą ịverti. Bazinè integravimo formule yra:

$$
X_{t+1}=\sum\left(X_{t+1}^{k} \times w\left(X_{t+1}^{k}\right)\right),
$$

čia $X_{t+1}$ - integruota prognoze; $X_{t+1}^{k}-\mathrm{k}$ periodo ilgio prognoze; $w\left(X_{t+1}^{k}\right)-\mathrm{k}$ periodo ilgio prognozès svoris bendrame įvertyje.

Efektyviam atskirų prognozių integravimo metodui sukurti turi būti parinkta tinkama palyginamoji bazé, kurios pagrindu bus nustatomi atskiru prognozių svoriai integruojant prognozes į bendrą įverti. Pagrindinis prognozavimo metodu efektyvumo vertinimo kriterijus yra juos naudojant gautu prognozių tikslumas, taigi, logiška, kad prognozių integravimo principas, analogiškai kaip tai padare Ustun ir Kasimbeyli (2012), būtų paremtas prognozavimo tikslumu.

Apibendrinant Firth ir Gift (1999), Sallehudin (2007), Ho ir Lee (1995), Antoniadis et al. (2006), Thawornwong ir Enke (2004), Kumar (2009), Dutta et al. (2006), Yao et al. (1999) ir Araujo (2010) galima išskirti šiuos prognozavimo tikslumo ịvertinimo metodus: prognozès paklaida (FE), absoliuti prognozès paklaida (AFE), vidutiné kvadratinè paklaida (MSE), vidutiné absoliuti prognozavimo paklaida (MAFE), šaknis iš vidutinès kvadratinès paklaidos (RMSE), vidutinè absoliuti procentinè paklaida (MAPE), vidutinis absoliutus nuokrypis (MAD), Theilo nelygybès koeficientas (TIC), santykinè vidutine absoliuti paklaida (RMAE), normalizuota vidutine standartiné paklaida (NMSE), krypties pokyčio prognozè (POCID) ir vidutinis santykinis neatitikimas (ARV).

Kuriant prognozių integravimo metodą tinkamiausio prognozavimo tikslumo vertinimo metodo pasirinkimas nèra kertinis veiksnys, todèl šiame darbe prognozių integravimo metodas bus kuriamas naudojant vidutinę kvadratinę paklaidą (MSE) kaip prognozavimo tikslumo mata.

Prognozes integruoti į bendrą ivertị siūloma pagal šią formulę:

$$
X_{t+1}=\sum_{k=1}^{m} \frac{X_{t+1}^{k} \times \sum_{k=1}^{m}\left(M S E_{t}^{k}\right)^{n}}{\left(M S E_{t}^{k}\right)^{n} \times \sum_{k=1}^{m} \frac{\sum_{k=1}^{m}\left(M S E_{t}^{k}\right)^{n}}{\left(M S E_{t}^{k}\right)^{n}}},
$$

čia $M S E_{t}^{k}-\mathrm{k}$ periodo ilgio laiko eilutès prognozių vidutinè kvadratinè paklaida, $\mathrm{n}$ - laipsnis, kuris yra naudojamas siekiant padidinti prognozès, gautos naudojant tiksliausią prognozavimo metoda, svori integruotoje prognozejje (geriausias „n“ bus pasiūlytas įvertinus empirinio tyrimo rezultatus). 
Pasiūlyta 2.7 formulè yra sudaryta tokiu būdu, kad integruotame ịvertyje (galutinèje prognozèje) didžiausią svori turès praeityje mažiausius vidutinius kvadratinius nuokrypius turèjusios prognozès.

\subsubsection{Pasiūlyto metodo testavimas}

Pasiūlyto skirtingo periodo laiko eilučių prognozių integravimo metodo tikslumas gali būti iqvertintas tik testuojamas realiomis rinkos sąlygomis. Šiuo tikslu buvo atliktas empirinis tyrimas. Šiam tyrimui atlikti ir jo reprezentatyvumui užtikrinti nèra svarbu, kokios akcijos ir indeksai yra pasirenkami analizei, pagrindinis jų atrankos kriterijus yra istorinių duomenu pakankamumas. Tyrimui pasirenkamos tiek atskiros akcijos, tiek indeksai, kadangi yra daroma prielaida, jog dèl didesnès diversifikacijos bus mažesni indeksu atsitiktiniai svyravimai (pvz., vienas stambesnis pardavejas gali laikinai sumažinti vienos akcijos kaina, bet poveikis indeksui bus minimalus). Iš viso tyrimui buvo atrinkti trys indeksai ir septynių imonių akcijos.

2.2 lentelè. Tyrimui atrinkti indeksai ir akcijos

Table 2.2. Indexes and stocks selected for analysis

\begin{tabular}{|c|c|}
\hline Pavadinimas & Trumpinys \\
\hline \multicolumn{2}{|c|}{ Indeksai } \\
\hline Dow Jones Industrial Average & Dow Jones \\
\hline NASDAQ Composite & NASDAQ \\
\hline S\&P 500 & $S \& P$ \\
\hline \multicolumn{2}{|c|}{ Akcijos } \\
\hline Alcoa Inc. & AA \\
\hline Boeing Company & $\mathrm{BA}$ \\
\hline Caterpillar, Inc. & CAT \\
\hline E. I. du Pont de Nemours and Company & DD \\
\hline General Electric Company & GE \\
\hline International Business Machines & IBM \\
\hline Coca-Cola Company & $\mathrm{KO}$ \\
\hline
\end{tabular}

Saltinis: sudaryta autoriaus

Pasirinkus tiriamuosius objektus svarbu nustatyti pagrindinius tyrimo parametrus. Šio poskyrio įžangoje buvo minèta, kad net tuo atveju, kai yra daromos trumpalaikès prognozès, svarbu yra įvertinti ne tik trumpalaikius akcijų grąžos svyravimus, bet ir ilgalaikes tendencijas, todèl šiam tyrimui buvo pasirinktas platus laiko eilučiu periodų ilgių spektras: 1, 2, 3, 4, 5, 10, 20, 40, 60, $90,120,180,240,360,480,720,960,1200,1500$ ir 1800 prekybos dienos. 
Laiko eilučiu analizei ir atskiroms prognozèms apskaičiuoti pasirenkami du metodai: paprastasis slankusis vidurkis (SMA) ir svertinis slankusis vidurkis (WMA).

Paprastasis slankusis vidurkis apskaičiuojamas pagal formulę:

$$
X_{t+1}^{k}=\frac{X_{t}+X_{t-1}+X_{t-2}}{3} .
$$

Svertinis slankusis vidurkis apskaičiuojamas taip:

$$
X_{t+1}^{k}=0,5 \times X_{t}+0,3 \times X_{t-1}+0,2 \times X_{t-2} .
$$

Kiekvienos analizuotos laiko eilutės prognozių vidutinè kvadratinė paklaida apskaičiuojama ívertinus paskutinių 1800 prekybos dienų (periodas lygus ilgiausiam periodui iš analizuotų laiko eilučių) kvadratines paklaidas.

Atliekant tyrimą bus vertinami trys laipsnio, naudojamo siekiant padidinti prognozès, gautos taikant tiksliausią prognozavimo metoda, svori integruotoje prognozeje (,n“ 2.7 formuleje) variantai: $n=1 ; n=2$ ir $n=3$.

Tyrimui atlikti bus naudojami kasdienių indeksų ir akcijų kainų pokyčių istoriniai duomenys. Duomenų analizès periodas buvo pasirinktas atsižvelgiant $\mathfrak{i}$ istorinių duomenų pakankamumą. Kadangi ilgiausias analizuotos laiko eilutės periodo ilgis 1800 prekybos dienu̧, 9000 prekybos dienų laikotarpis yra naudojamas prognozių integravimui reikalingiems duomenims nustatyti, o likęs periodas naudojamas pasiūlyto metodo efektyvumui testuoti. Atsižvelgiant i duomenu pakankamuma, atskiriems tiriamiems objektams buvo atliktas skirtingas prognozavimo efektyvumo testavimo bandymų skaičius, jis yra pateikiamas 2.3 lentelèje.

2.3 lentelè. Prognozavimo efektyvumo bandymų skaičius

Table 2.3. Forecasting efficiency testing periods

\begin{tabular}{|l|c|c|}
\hline Indeksas/akcija & Bandymų skaičius & Testuojamas laikotarpis \\
\hline Dow Jones & 11761 & $1964-2011$ \\
\hline NASDAQ & 1264 & $2006-2011$ \\
\hline S\&P & 6544 & $1985-2011$ \\
\hline AA & 3527 & $1997-2011$ \\
\hline BA & 3528 & $1997-2011$ \\
\hline CAT & 3528 & $1997-2011$ \\
\hline DD & 3527 & $1997-2011$ \\
\hline GE & 3527 & $1997-2011$ \\
\hline IBM & 3526 & $1997-2011$ \\
\hline KO & 3528 & $1997-2011$ \\
\hline
\end{tabular}

Šaltinis: sudaryta autoriaus 
2.3 lentelè parodo, kad daugiausiai istorinių duomenų analizei turejo Dow Jones indeksas, kuris leido testuoti pasiūlytą metodą beveik 50 metų laikotarpiu, taigi vertinant prognozių integravimo metodo efektyvumą daugiausia dèmesio bus skiriama Dow Jones indekso pokyčių prognozavimo rezultatams.

Pasiūlyto skirtingų periodų laiko eilučių prognozių integravimo metodo efektyvumo vertinimas bus atliekamas lyginant prognozių, gautų taikant pasiūlytą metoda, tikslumą su tiksliausiomis iš neintegruotų prognozių - vienos prekybos dienos periodo laiko eilutės prognozèmis, kurios šiuo atveju sutampa su taikant Ustun ir Kasimbeyli (2012) modeli gautomis prognozèmis. Pasiūlyto metodo, kaip prognozavimo tikslumo didinimo priemonès, efektyvumas ivertinamas skaičiuojant vidutinès kvadratinès paklaidos pokyti lyginant su vienos prekybos dienos periodo ilgio laiko eilutès prognoze. Gauti rezultatai pateikiami 2.4-2.7 lentelèse.

2.4 lentelè. Efektyvumas integruojant paprastojo slankiojo vidurkio indeksų prognozes, \% Table 2.4. Efficiency integrating single moving average index forecasts, $\%$

\begin{tabular}{|l|c|c|c|c|}
\hline MSE pokytis ( $\triangle$ MSE) & Dow Jones & Nasdaq & S\&P & Vidurkis \\
\hline$\triangle$ MSE $(n=1)$ & $-2,18$ & $-9,37$ & $-5,93$ & $-5,83$ \\
\hline$\triangle M S E(n=2)$ & $-16,51$ & $-20,33$ & $-18,14$ & $-18,33$ \\
\hline$\triangle M S E(n=3)$ & $-10,42$ & $-15,03$ & $-15,30$ & $-13,58$ \\
\hline
\end{tabular}

Šaltinis: sudaryta autoriaus

2.5 lentelè. Efektyvumas integruojant paprastojo slankiojo vidurkio akcijų prognozes, \% Table 2.5. Efficiency integrating single moving average stock forecasts, $\%$

\begin{tabular}{|l|c|c|c|c|c|c|c|c|}
\hline MSE pokytis & AA & BA & CAT & DD & GE & IBM & KO & Vidurkis \\
\hline$\triangle$ MSE $(\mathrm{n}=1)$ & 4,90 & 4,86 & 1,41 & 3,00 & 3,11 & $-2,90$ & $-1,90$ & 1,78 \\
\hline$\triangle M S E(n=2)$ & $-16,41$ & $-15,25$ & $-16,43$ & $-17,47$ & $-17,07$ & $-17,51$ & $-16,96$ & $-16,73$ \\
\hline$\Delta$ MSE $(\mathrm{n}=3)$ & $-10,83$ & $-10,79$ & $-11,06$ & $-12,16$ & $-12,05$ & $-12,61$ & $-10,91$ & $-11,49$ \\
\hline
\end{tabular}

Saltinis: sudaryta autoriaus

2.6 lentelè. Efektyvumas integruojant svertinio slankiojo vidurkio indeksų prognozes, \% Table 2.6. Efficiency integrating weighted moving average index forecasts, $\%$

\begin{tabular}{|l|c|c|c|c|}
\hline MSE pokytis & Dow Jones & Nasdaq & S\&P & Vidurkis \\
\hline$\triangle \operatorname{MSE}(n=1)$ & $-10,32$ & $-18,08$ & $-13,98$ & $-14,13$ \\
\hline$\triangle \operatorname{MSE}(n=2)$ & $-21,30$ & $-26,28$ & $-24,32$ & $-23,97$ \\
\hline$\Delta \operatorname{MSE}(n=3)$ & $-13,09$ & $-18,89$ & $-16,10$ & $-16,03$ \\
\hline
\end{tabular}

Šaltinis: sudaryta autoriaus 
2.7 lentelè. Efektyvumas integruojant svertinio slankiojo vidurkio akcijų prognozes, \% Table 2.7. Efficiency integrating weighted moving average stock forecasts, \%

\begin{tabular}{|l|c|c|c|c|c|c|c|c|}
\hline MSE pokytis & AA & BA & CAT & DD & GE & IBM & KO & Vidurkis \\
\hline$\triangle \operatorname{MSE}(n=1)$ & $-3,47$ & $-3,69$ & $-7,36$ & $-5,59$ & $-5,31$ & $-10,74$ & $-9,35$ & $-8,47$ \\
\hline$\triangle M S E ~(n=2)$ & $-21,36$ & $-20,54$ & $-21,61$ & $-22,70$ & $-22,06$ & $-22,70$ & $-21,74$ & $-22,17$ \\
\hline$\triangle M S E(n=3)$ & $-13,65$ & $-13,85$ & $-14,01$ & $-15,21$ & $-14,93$ & $-15,76$ & $-13,74$ & $-14,81$ \\
\hline
\end{tabular}

Šaltinis: sudaryta autoriaus

Iš 2.4-2.7 lentelių matyti, kad pasiūlytas skirtingu periodų laiko eilučių prognozių integravimo metodas pagerina prognozavimo tikslumą. Vidutiné kvadratine paklaida labiausiai sumažèja, kai „n“ 2.7 formulèje yra lygus 2 , t. y. formulę galima užrašyti taip:

$$
X_{t+1}=\sum_{k=1}^{m} \frac{X_{t+1}^{k} \times \sum_{k=1}^{m}\left(M S E_{t}^{k}\right)^{2}}{\left(M S E_{t}^{k}\right)^{2} \times \sum_{k=1}^{m} \frac{\sum_{k=1}^{m}\left(M S E_{t}^{k}\right)^{2}}{\left(M S E_{t}^{k}\right)^{2}} .}
$$

Tolesnis tyrimas ir rezultatų vertinimas bus atliekamas taikant būtent šią formulę. 2.4-2.7 lentelès parodo, kad integruojant paprastuoju slankiuoju vidurkiu padarytas prognozes vidutinè kvadratinè paklaida vidutiniškai sumažèjo indeksu atveju - 18,33 proc., akcijų atveju - 16,73 proc.; o integruojant svertinio slankiojo vidurkio prognozes atitinkamai 23,97 ir 22,17 proc.

Detalūs duomenys apie skirtingais būdais apskaičiuotų prognozių tikslumą (vidutines kvadratines paklaidas) yra pateikti $F$ priede, kuriame matyti, jog tiksliausiai vykdant tyrimą (tiek taikant pasiūlytą metoda, tiek skaičiuojant paprastuosius slankiuosius vidurkius) pavyko prognozuoti S\&P ir Dow Jones indeksų pokyčius. Indeksų pokyčio prognozių integravimas taip pat leido daugiau nei akcijų atveju sumažinti vidutines kvadratines paklaidas. Pažymėtina, kad prognozių integravimo efektyvumas nèra nulemtas ilgesnio nei akcijų analizès termino, nes vertinant analogišką bandymų skaičių (3528) Dow Jones vidutinès kvadratinès paklaidos pokytis yra $-18,87$ proc. (SMA atveju) ir $-24,67$ proc. (WMA atveju), S\&P atitinkamai $-19,93$ ir $-25,4$ proc., nors bendras prognozavimo tikslumas 3528 prekybos dienų laikotarpiu ir buvo mažesnis nei visu analizuotu laikotarpiu. Tai leidžia teigti, jog pasirenkant objektus metodui bandyti iškelta prielaida, kad indeksų pokyčiai dèl didesnès diversifikacijos ir mažesnių atsitiktinių svyravimų galètų būti tiksliau prognozuojami nei akcijų gražzos. 
Pastebėtina, kad atskiros skirtingų periodų laiko eilučių prognozės buvo tikslesnès naudojant paprastaji slankuji vidurkị, tačiau integruotos prognozès buvo tikslesnès naudojant svertini slankuji vidurki, tai iš esmès patvirtina nuogąstavima, kad HCSOM modelyje (Afolabi, Olude 2007) numatyta tik geriausių neuronų atranka ir visiškas likusiujų neuronų ignoravimas negali užtikrinti, kad bus išnaudotos visos prognozių integravimo galimybès.

Pasiūlyto metodo efektą ir naudą taip pat galima matyti histogramoje (2.16 pav.), kuri parodo, jog mažos prognozavimo paklaidos dažniau pasikartodavo integruotu prognozių atveju, tačiau tai neleido išvengti didelių prognozavimo klaidų.

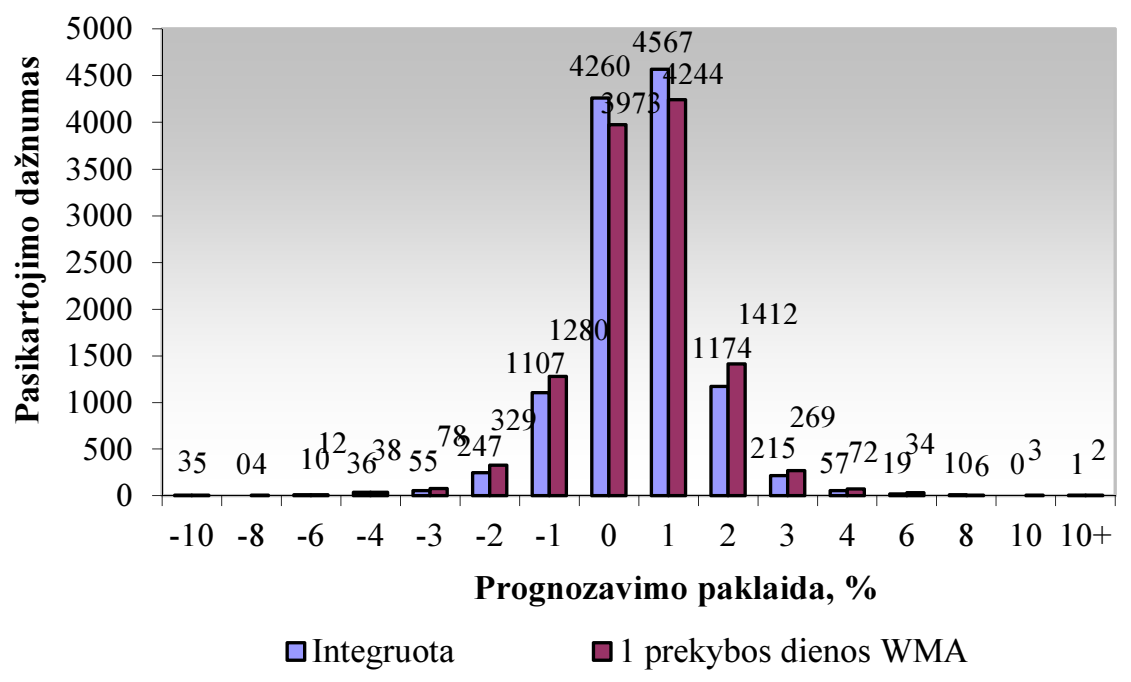

2.16 pav. Dow Jones indekso prognozavimo paklaidos pasiskirstymas

Fig. 2.16. Forecasting errors distribution in case of Dow Jones index S̆altinis: sudaryta autoriaus

Prognozavimo paklaidu svyravimai atskirais laikotarpiais pateikiami $2.17 \mathrm{ir}$ 2.18 paveiksluose. Iš jų matyti, jog per 2008 metų globalią finansų krizę prognozavimo paklaidos buvo padidèjusios, tačiau iš paveikslų gerai matyti, jog per pati finansų krizès piką integruotų prognozių paklaidos buvo mažesnès nei vienos dienos periodo trukmės laiko eilučiuc prognozès, gautos naudojant svertinio slankiojo vidurkio metodą. 


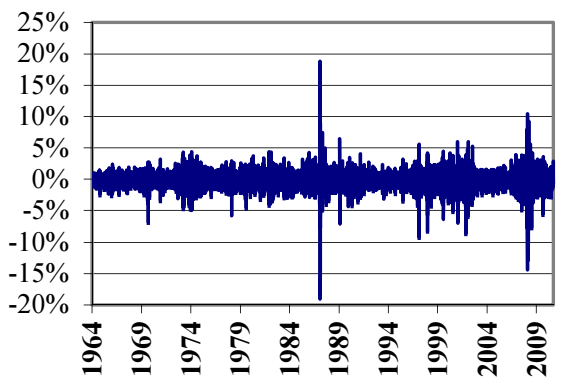

2.17 pav. 1 dienos WMA prognozès paklaidos

Fig. 2.17. 1 day WMA forecast error Šaltinis: sudaryta autoriaus

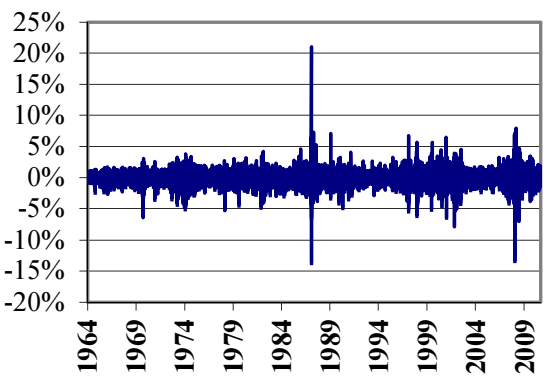

2.18 pav. Integruotos prognozès paklaida Fig. 2.18. Integrated forecast error Šaltinis: sudaryta autoriaus

Kadangi metodas buvo testuojamas prognozuojant akcijų kainų ir akcijų indeksu pokyčius, kurie yra tarpusavyje koreliuoti, papildomai buvo testuota valiutų rinkoje. Metodui testuoti buvo atrinktos 7 valiutų poros: EUR/USD; EUR/JPY; EUR/CHF; EUR/GBP; USD/JPY; USD/CHF; CHF/JPY. Analizei atrenkamas 2001-10-18 - 2012-05-17 laikotarpis vertinant valandinius valiutu kursu pokyčius (iš viso 65000 analizuoti laikotarpiai, iš kurių 9000 analizuoti siekiant surinkti reikiamus duomenis metodui taikyti ir 56000 - realiai metodui testuoti). Visi kiti metodo parametrai yra tie patys, kurie buvo taikyti integruojant indeksų ir akcijų grąžos prognozes.

2.8 lentelè. Efektyvumas integruojant SMA valiutų kursų prognozes

Table 2.8. Efficiency integrating single moving average currency rates forecasts

\begin{tabular}{|l|c|c|c|c|c|c|c|}
\hline & EUR/USD & EUR/JPY & EUR/CHF & EUR/GBP & USD/JPY & USD/CHF & CHF/JPY \\
\hline 1 valandos & 0,025 & 0,040 & 0,012 & 0,015 & 0,040 & 0,030 & 0,035 \\
\hline Integruota & 0,021 & 0,033 & 0,010 & 0,013 & 0,033 & 0,025 & 0,029 \\
\hline$\Delta$ MSE & $-16,11 \%$ & $-16,43 \%$ & $-16,15 \%$ & $-16,37 \%$ & $-16,43 \%$ & $-15,75 \%$ & $-16,86 \%$ \\
\hline
\end{tabular}

Śltinis: sudaryta autoriaus

2.9 lentelè. Efektyvumas integruojant WMA valiutų kursų prognozes

Table 2.9. Efficiency integrating weighted moving average currency rates forecasts

\begin{tabular}{|l|c|c|c|c|c|c|c|}
\hline & EUR/USD & EUR/JPY & EUR/CHF & EUR/GBP & USD/JPY & USD/CHF & CHF/JPY \\
\hline 1 valandos & 0,025 & 0,041 & 0,013 & 0,016 & 0,028 & 0,031 & 0,037 \\
\hline Integruota & 0,020 & 0,032 & 0,010 & 0,013 & 0,022 & 0,024 & 0,029 \\
\hline$\Delta$ MSE & $-21,23 \%$ & $-21,53 \%$ & $-21,76 \%$ & $-21,67 \%$ & $-21,74 \%$ & $-20,96 \%$ & $-22,13 \%$ \\
\hline
\end{tabular}

Saltinis: sudaryta autoriaus 
2.8 ir 2.9 lentelès parodo, kad, analogiškai akcijų kainos ir indeksų pokyčių prognozavimui, prognozavimo paklaidos labiau sumažejo integruojant svertinio slankiojo vidurkio metodu padarytas prognozes (vidutiniškai 21,33 proc.) negu integruojant paprastojo slankiojo vidurkio metodu padarytas prognozes (vidutiniškai 16,3 proc.).

Atsižvelgiant ị tai, jog vidutinès kvadratinès paklaidos skaičiavimas įvertina paklaidas, pakeltas kvadratu, o ne paklaidas absoliučiu dydžiu, kurios yra aktualesnès ir geriau suvokiamos investuotojui, pasiūlytas metodas taip pat buvo testuotas vertinant vidutinès absoliučios prognozavimo paklaidos pokyčius. Vidutinès absoliučios prognozavimo paklaidos (MAFE) sumažèjimas integruojant SMA ir WMA metodais gautas prognozes pagal 2.10 formulę pateikiamas 2.10-2.12 lentelèse.

2.10 lentelè. MAFE pokyčiai integruojant indeksų prognozes, $\%$

Table 2.10. MAFE changes integrating index forerecasts, $\%$

\begin{tabular}{|l|c|c|c|c|}
\hline MAFE pokytis & Dow Jones & Nasdaq & S\&P & Vidurkis \\
\hline DAFE (SMA) & $-10,79$ & $-10,27$ & $-11,59$ & $-10,88$ \\
\hline MAFE (WMA) & $-14,05$ & $-14,37$ & $-14,92$ & $-14,45$ \\
\hline
\end{tabular}

Šaltinis: sudaryta autoriaus

2.11 lentelè. MAFE pokyčiai integruojant akcijų prognozes, \%

Table 2.11. MAFE changes integrating stock forerecasts, $\%$

\begin{tabular}{|l|c|c|c|c|c|c|c|c|}
\hline MAFE pokytis & AA & BA & CAT & DD & GE & IBM & KO & Vidurkis \\
\hline$\triangle$ MAFE (SMA) & $-8,34$ & $-8,68$ & $-9,18$ & $-9,04$ & $-10,08$ & $-9,94$ & $-9,06$ & $-9,19$ \\
\hline$\triangle$ MAFE (WMA) & $-11,47$ & $-11,27$ & $-11,85$ & $-12,17$ & $-12,76$ & $-12,32$ & $-12,21$ & $-12,01$ \\
\hline
\end{tabular}

Saltinis: sudaryta autoriaus

2.12 lentelè. MAFE pokyčiai integruojant valiutų kursų prognozes, $\%$

Table 2.8. MAFE changes integrating currency rates forecasts, $\%$

\begin{tabular}{|l|c|c|c|c|c|c|c|}
\hline $\begin{array}{l}\text { MAFE } \\
\text { pokytis }\end{array}$ & EUR/USD & EUR/JPY & EUR/CHF & EUR/GBP & USD/JPY & USD/CHF & CHF/JPY \\
\hline $\begin{array}{l}\text { MMAFE } \\
\text { (SMA) }\end{array}$ & $-9,95$ & $-9,9$ & $-10,46$ & $-9,46$ & $-9,9$ & $-9,96$ & $-10,25$ \\
\hline $\begin{array}{l}\text { MMAF } \\
\text { (WMA) }\end{array}$ & $-12,7$ & $-12,64$ & $-13,48$ & $-12,4$ & $-13,17$ & $-12,68$ & $-13,05$ \\
\hline
\end{tabular}

Šaltinis: sudaryta autoriaus

Pasiūlyto prognozių integravimo metodo testavimas taikant vidutinę absoliučią prognozavimo paklaida, kaip prognozavimo tikslumo matą, parodè, 
kad MAFE pokyčiai integruojant prognozes buvo mažesni nei MSE pokyčiai, tačiau buvo pakankami (vidutiniškai 9,48 proc. integruojant paprastojo slankiojo vidurkio metodu gautas prognozes ir apie 12,84 proc. integruojant WMA metodu gautas prognozes), kad galima būtų teigti, jog pasiūlyto metodo taikymas yra efektyvi priemone didinant prognozavimo tikslumą.

\subsection{Sprendimo keisti portfelio sudèti prièmimas}

\subsubsection{Problemos ištirtumo lygis kitų mokslininkų darbuose}

Vienas iš esminių veiksnių, nulemiančių sprendimų keisti portfelio sudèti priemimą yra portfelio sudeties keitimo strategijos pasirinkimas. Dierkes et al. (2010) išskiria dvi pagrindines investavimo strategijų grupes: prognozemis paremtas ir prognozių neįvertinančias strategijas. Leung (2011) išskiria tris strategijų grupes, kurios santykiškai gali būti priskirtos prognozių neįvertinančioms strategijoms: fiksuoto turto paskirstymo bėgant laikui ir turto paskirstymo, kuris kinta laike pagal iš anksto nustatytas taisykles; bei prognozèmis paremtoms strategijoms - portfelio sudèties keitimo taisyklès, kai turto paskirstymas ateityje priklauso nuo investavimo rezultatų iki sprendimu priemimo momento. Dierkes et al. (2010), Jones ir Stine (2010) nagrineja tris pagrindines prognozių neịvertinančias portfelio sudèties keitimo strategijas: pirk ir laikyk, pastovaus derinio bei pastoviu proporciju portfelio draudimas. Cesari ir Cremonini (2003), be jau minètu strategijų analizavo opcionais paremtas ir technines strategijas. O`Brien (2006) analizavo periodinio sudèties keitimo, pakopinio sudeties keitimo, ribinio ir aktyvaus sudèties keitimo strategijas, Eakins ir Stansell (2007) - priežastinio ir periodinio portfelio sudèties keitimo strategijas. Feng et al. (2011), Kozat ir Singer (2011) teigimu, dažnas portfelio sudèties keitimas esant sandorių sąnaudoms gali būti nepelningas, todèl pasiūlè peržiūrèti portfelio sudèti ne kiekvieną perioda, o tik tam tikrais intervalais. Kuhn ir Leunberger (2010) nustatè, kad praradimai dèl nedažno portfelio sudèties keitimo yra labai nedideli, o gera portfelio diversifikacija gali sumažinti neigiamą nedažno portfelio sudèties keitimo poveiki.

Yu, Lee (2011) nagrinèdami portfelio sudèties keitimo problemą dideli dèmesị kreipia į trumpujų pozicijų (angl. short selling) turèjimo galimybę ir be vidurkio dispersijos modelio (ivertinančio sandorių sąnaudas) pasiūlè keturis daugiatikslius modelius portfelio sudèties keitimo problemai spręsti: vidurkiodispersijos-trumpujų poziciju, vidurkio-dispersijos-trumpujų pozicijųasimetrijos, vidurkio-dispersijos-trumpujų pozicijų-eksceso bei vidurkiodispersijos-trumpujų pozicijų-asimetrijos-eksceso modelius, taip pat numate neapibrèžto daugiatikslio programavimo taikymą pasiūlytiems modeliams 
igyvendinti. Sandorių sąnaudos turi labai didelę itaką investavimo rezultatams aktyviai valdant investicijų portfeli, todèl portfelio sudeties keitimo problematiką nagrinejjantys mokslininkai (Zhang et al. 2012, 2011a, 2011b, 2010a, 2010b; Bhattacharyya et al. 2011; Fang et al. 2006; Feng et al. 2011) didelị dèmesị kreipia būtent ị sandorių sąnaudų îvertinimą.

Zhang et al. (2012, 2011a, 2010b) ir Bhattacharyya et al. (2011) sandorių sąnaudoms įvertinti taiko formulę:

$$
C=\sum_{i=1}^{n} c_{t, i}\left|w_{t, i}-w_{t-1, i}\right|
$$

čia C - bendrosios sandorių sąnaudos; $c_{t, i}$ - sandorių sąnaudos, tenkančios vienam rizikingo aktyvo $\mathrm{i}$ vertés vienetui $\mathrm{t}$ periodu; $w_{t, i}-\mathrm{t}$ periodu $\mathrm{i}$ i akciją investuotų lèšų suma.

Zhang et al. (2010a, 2011b) pateikiama kiek platesnè formulè, numatanti naujuc aktyvų itraukimą $\mathfrak{i}$ portfelị ir skirtingas vertybinių popierių pirkimo ir pardavimo sąnaudas:

$$
C=\sum_{i=1}^{k}\left(c_{i}^{+} w_{i}^{+}+c_{i}^{-} w_{i}^{-}\right)+\sum_{j=k+1}^{n} c_{j}^{+} w_{j},
$$

čia $c_{i}^{+}-\mathrm{i}$ aktyvo issigijimo sandorių sąnaudos; $c_{i}^{-}-\mathrm{i}$ aktyvo pardavimo sandorių sąnaudos; $\mathrm{j}$ - naujai įtraukiamas i portfelio sudèti aktyvas.

Zhang et al. (2012, 2011a, 2011b, 2010a, 2010b) ir Bhattacharyya et al. (2011) laukiamą portfelio pelningumą (kuri siekiama maksimizuoti arba turèti ne mažesnį už nustatytą lygi) i̇vertina kaip laukiamos grąžos ir sandorių sąnaudų skirtumą. Jei sandorių sąnaudoms skaičiuoti taikoma 2.12 formule, laukiama grąža nustatoma pagal formulę:

$$
E(R)=\sum_{i=1}^{n} E\left(R_{i}\right) w_{i}-\sum_{i=1}^{k}\left(c_{i}^{+} w_{i}^{+}+c_{i}^{-} w_{i}^{-}\right)-\sum_{j=k+1}^{n} c_{j}^{+} w_{j} .
$$

Didžioji dalis portfelio sudèties keitimo problematiką nagrinejjančių mokslininkų remiasi neapibrežtų (angl. fuzzy) sprendimų požiūriu, kurio taikymas plačiai yra aprašytas Zhang et al. (2012, 2011a, 2011b, 2010a, 2010b), Bhattacharyya et al. (2011), Fang et al. (2006) ir Feng et al. (2011) darbuose. Tačiau siekiant pasiūlyti sprendimo keisti portfelio sudèti prièmimo metodą svarbus ne konkretaus požiürio taikymas, o pats sprendimo prièmimo principas kokių tikslų siekiama priimant sprendimus. Siūlomi galimi sprendimų prièmimo principai pateikiami 2.10 lentelèje. 
2.13 lentelè. Portfelio sudèties keitimo tikslai

Fig. 2.13. Porfolio rebalancing objectives

\begin{tabular}{|c|c|}
\hline Šaltinis & Tikslai, keliami priimant sprendimą keisti portfelio sudèti \\
\hline $\begin{array}{lll}\text { Zhang } & \text { et } \\
2012 & & \end{array}$ & $\begin{array}{l}\text { Minimizuoti riziką ir maksimizuoti portfelio diversifikacijos lygi } \\
\text { esant ne mažesnei nei pageidaujama gražos normai }\end{array}$ \\
\hline $\begin{array}{l}\text { Bhattacharyya } \\
\text { et al. } 2011\end{array}$ & Minimizuoti rizika, maksimizuoti laukiamą grąžą ir asimetriją \\
\hline $\begin{array}{l}\text { Zhang et al. } \\
\text { 2011a }\end{array}$ & $\begin{array}{l}\operatorname{Max} U(x)=E(R)-0,005 \times A \times \text { Var, čia } \mathrm{A}-\text { rizikos } \\
\text { tolerancijos lygis, Var }- \text { rizika. }\end{array}$ \\
\hline $\begin{array}{lll}\text { Zhang } & \text { et } a l . \\
2011 \mathrm{~b} & & \end{array}$ & Min $A \times(-E(R))+$ Var \\
\hline $\begin{array}{l}\text { Zhang et al. } \\
2010 \mathrm{a}\end{array}$ & $\begin{array}{l}\text { Minimizuoti riziką esant ne mažesnei nei pageidaujama grąžos } \\
\text { normai }\end{array}$ \\
\hline $\begin{array}{lll}\text { Zhang } & \text { et } & \text { al. } \\
2010 \mathrm{~b} & & \end{array}$ & $\begin{array}{l}\text { Minimizuoti riziką ir maksimizuoti grąžą arba } \\
\text { Min }-A \times E(R)+\text { Var }\end{array}$ \\
\hline $\begin{array}{lll}\text { Fang } & \text { et } & \text { al. } \\
2006 & & \end{array}$ & $\begin{array}{l}\text { Maksimizuoti laukią grą̌za ir minimizuoti riziką esant ne } \\
\text { mažesniam nei pageidaujama portfelio likvidumui }\end{array}$ \\
\hline
\end{tabular}

Šltinis: sudaryta autoriaus

Iš 2.10 lentelès matyti, kad visais atvejais buvo vertintos dvi pagrindinès portfelio charakteristikos - laukiamas pelningumas ir rizika. Ir tik po vieną atveji buvo itrauktos tokios charakteristikos kaip diversifikacija, asimetrija ir likvidumas. Iš visų lentelèje pateiktų darbų atskirą dèmesi reikètų atkreipti i Zhang et al. (2011b) darba, kuriame taip pat yra ivertintos nerizikingo skolinimo/ skolinimosi galimybès. Taigi 2.10 lentelèje pateiktoje formulèje laukiama grąža yra apskaičiuojama pagal formulę:

$$
E\left(R_{p}\right)=\sum_{i=1}^{n} E\left(R_{i}\right) w_{i}+r_{-} w_{-}-r_{+} w_{+}-\sum_{i=1}^{k}\left(c_{i}^{+} w_{i}^{+}+c_{i}^{-} w_{i}^{-}\right)-\sum_{j=k+1}^{n} c_{j}^{+} w_{j},
$$

čia $r_{-}$- nerizikingo skolinimo palūkanų norma; $w_{-}-$lèšos, skolinamos už nerizikingą palūkanų normą; $r_{+}-$nerizikingo skolinimosi palūkanų norma; $w_{+}$ - lèšų suma, pasiskolinama už nerizikingą palūkanų normą.

Nerizikingo skolinimo(si) sąnaudų ịvertinimas leidžia priimti efektyvesnius sprendimus aktyviai valdant investicijų portfelį taikant finansinị svertą.

\subsubsection{Siūlomas sprendimo keisti portfelio sudèti prièmimo metodas}

Atlikta portfelio sudèties keitimo mokslinių darbų analizè parodè, kad šia tema parengtų darbų nèra daug. Juos galima suskirstyti į dvi grupes - portfelio 
sudèties keitimo strategijas nagrinejjančius darbus ir darbus kuriuose nagrinejjamas tiesioginis portfelio sudèties keitimo problemos sprendimas. Kokią portfelio sudèties keitimo strategija pasirinkti, kiekvienas investuotojas gali nuspręsti savarankiškai, daug svarbiau yra turèti metodą, leidžianti priimti tinkamus sprendimus dèl portfelio sudèties keitimo. Ivertinus mokslininkų pasiūlymus dèl portfelio sudèties keitimo reikia pastebèti, kad pagrindinis dèmesys juose yra kreipiamas i sandorių sąnaudų ivertinimą ir portfelio optimizavimą iš laukiamos grąžos atemus sąnaudas. Tačiau toks požiūris $\mathfrak{i}$ portfelio sudèties keitimą negali užtikrinti, kad investuotojo poreikiai bus patenkinti ir taip atsitinka visų pirma dèl to, kad keisdamas investicijų portfelio sudèti investuotojas iš karto patiria nustatytus nuostolius, o investicijos gali pasiekti laukiamą pelningumo lygi, arba jo nepasiekti, t. y. tuo atveju, kai laukiamas pelningumas tik neženkliai viršija realiai patiriamas sąnaudas investuotojas nebus linkęs keisti portfelio sudeties. Zhang et al. (2010a) pasiūlyto portfelio sudèties keitimo sprendimo, siekiant minimizuoti riziką esant ne mažesnei nei pageidaujama investicijų grą̌̌ai, tiesioginis taikymas gali nulemti didesnio laukiamo pelningumo portfelio atsisakymą ir mažesnès laukiamos grąžos portfelio pasirinkimą. Todèl portfelio sudèties keitimo metodas turi užtikrinti, kad laukiamas portfelio pelningumas įvertinus sandorių sąnaudas ne tik padidès, bet ir bent tam tikru lygiu viršys patirtas sandorių sąnaudas.

Sprendimo keisti portfelio sudeti priemimo metodas bus kuriamas remiantis dviem pagrindinemis portfelio charakteristikomis - pelningumu ir rizika, analogiškai kaip Zang et al. (2011a, 2011b, 2010a, 2010b). Kitu parametrų likvidumo, diversifikacijos lygio - nuspręsta atsisakyti. Investuotojas vykdydamas vertybinių popierių atranką iš karto turètų pasirinkti tik likvidžius vertybinius popierius, nes aktyvus portfelio valdymas itraukiant nelikvidžius vertybinius popierius gali būti nuostolingas dèl didesnių pirkimo ir pardavimo kainų skirtumų. Diversifikacija yra aktualesné, kai investuojama ilgesniam laikotarpiui, bet, aktyviai valdydamas portfeli, investuotojas uždirba iš kainu svyravimo, t. y. nediversifikuotas portfelis gali potencialiai užtikrinti didesnę investicijų grąžą nei diversifikuotas, plati diversifikacija taip pat gali padidinti portfelio sudèties keitimo sąnaudas.

Tarkime, visa šiuo metu sudaryto portfelio $\left(\mathrm{p}_{0}\right)$ i rizikingus aktyvus (pvz., akcijas) investuota suma yra lygi $\mathrm{W}^{\mathrm{t}-1}$ :

$$
w^{t-1}=\sum_{i=1}^{n} w_{i}^{t-1},
$$

čia $w_{i}^{t-1}-\mathrm{i}$ i akciją investuota lèšų suma. 
Nekeičiant portfelio sudèties laukiamas jo pelningumas t laikotarpiu būtų apskaičiuojamas:

$$
E\left(R_{p_{0}}\right)=\sum_{i=1}^{n} w_{i}^{t-1} E\left(R_{i}^{t}\right)
$$

čia $E\left(R_{i}{ }^{\dagger}\right)$ - laukiamas i akcijos pelningumas t laikotarpiu.

Ivertinus nerizikingo skolinimo pajamas ir skolinimosi sąnaudas esamo portfelio laukiamas pelningumas t laikotarpiu yra lygus:

$$
E\left(R_{p_{0}}\right)=\sum_{i=1}^{n} w_{i}^{t-1} E\left(R_{i}^{t}\right)+r_{-} w_{-}^{t-1}-r_{+} w_{+}^{t-1} .
$$

Laukiama pakeistos sudèties portfelio (p) grąža, kai sandorių sąnaudos nustatomos pagal 2.12 formulę, yra lygi:

$$
E\left(R_{p_{0}}\right)=\sum_{i=1}^{n} w_{i}^{t} E\left(R_{i}^{t}\right)+r_{-} w_{-}^{t}-r_{+} w_{+}^{t}-\sum_{i=1}^{k}\left(c_{i}^{+} w_{i}^{+}+c_{i}^{-} w_{i}^{-}\right)-\sum_{j=k+1}^{n} c_{j}^{+} w_{j} .
$$

Portfelio rizika (dispersija) apskaičiuojama:

$$
\sigma_{p}^{2}=\sum_{i=1}^{N} \sum_{j=1}^{M} w_{i} w_{j} \operatorname{COV}\left(R_{i} R_{j}\right)
$$

Portfelis optimizuojamas maksimizuojant investuotojo naudingumo funkciją:

$$
\begin{aligned}
& \max U(w)=\sum_{i=1}^{n} w_{i}^{t} E\left(R_{i}^{t}\right)+r_{-} w_{-}^{t}-r_{+} w_{+}^{t}-\sum_{i=1}^{k}\left(c_{i}^{+} w_{i}^{+}+c_{i}^{-} w_{i}^{-}\right)-\sum_{j=k+1}^{n} c_{j}^{+} w_{j}- \\
& A \sum_{i=1}^{N} \sum_{j=1}^{M} w_{i} w_{j} \operatorname{COV}\left(R_{i} R_{j}\right) .
\end{aligned}
$$

arba kai investuotojas iš anksto yra numatęs maksimalu priimtiną rizikos lygi $\hat{\sigma}_{p}^{2}-\sigma_{p}^{2} \leq \hat{\sigma}_{p}^{2}$, maksimizuojant laukiamą pelningumą:

$$
\max E\left(R_{p}\right)=\sum_{i=1}^{n} w_{i}^{t} E\left(R_{i}^{t}\right)+r_{-} w_{-}^{t}-r_{+} w_{+}^{t}-\sum_{i=1}^{k}\left(c_{i}^{+} w_{i}^{+}+c_{i}^{-} w_{i}^{-}\right)-\sum_{j=k+1}^{n} c_{j}^{+} w_{j},
$$

kai: $w_{i}^{t}, w_{-}^{t}, w_{+}^{t} \geq 0$

$$
\sum_{i=1}^{n} w_{i}^{t}+w_{-}^{t}-w_{+}^{t}-\sum_{i=1}^{k}\left(c_{i}^{+} w_{i}^{+}+c_{i}^{-} w_{i}^{-}\right)-\sum_{j=k+1}^{n} c_{j}^{+} w_{j}=W,
$$


jeigu nerizikingo skolinimosi galimybès yra ribotos, taip pat turi būti tenkinama sąlyga: $w_{+}^{t} \leq w_{+}^{\max }$, esant minimaliai nerizikingo skolinimo sumai ir rizikingu aktyvų issigijimo apimčiai atitinkamai: $w_{-}^{t} \leq w_{-}^{\min }$ ir $w_{i}^{t} \leq w_{i}^{\min }$, čia A - rizikos tolerancijos lygis; W - investicijoms skirta investuotojo lèšu suma; $w_{+}^{\max }-$ maksimali suma, kurią galima pasiskolinti už nerizikingą palūkanų norma; $w_{-}^{\min }-$ minimali nerizikingų investicijų suma; $w_{i}^{\min }-$ minimali rizikingų investicijų suma $i \underset{i}{i}$ akciją.

Sprendimas keisti portfelio sudeti priimamas ivertinus esamo portfelio laukiamą pelningumą ateinančiu laikotarpiu, optimalaus portfelio laukiamą pelningumą ir keičiant portfelio sudeti patiriamas sandorių sąnaudas. Portfelio sudètis bus keičiama tik kai tenkinama nelygybè:

$$
K=f\left(E\left(R_{p_{0}}\right) ; E\left(R_{p}\right) ; C\right) \geq K_{\min },
$$

čia K - kriterijaus, kuriuo remiantis priimamas sprendimas keisti portfelio sudèti, reikšmé; $\mathrm{K}_{\min }$ - minimali kriterijaus reikšmè, kad būtų priimtas sprendimas keisti portfelio sudetit.

$\mathrm{K}_{\min }$ kriterijaus reikšme yra individuali kiekvienam investuotojui ir priklauso nuo investuotojo gaunamų prognozių tikslumo (investuotojo pasitikejjimo naudojamais prognozavimo metodais ir programomis) bei investuotojo polinkio keisti portfelio sudetit.

Vienas iš galimų 2.23 formulès konkretizavimo atvejų yra laukiamo pelningumo perviršio ir patiriamų sąnaudų santykis. Portfelio sudètis keičiama, kai yra tenkinama nelygybè:

$$
\frac{E\left(R_{p}\right)-E\left(R_{p_{0}}\right)}{C} \geq K_{\min } .
$$

Jeigu $\mathrm{K}_{\text {min }}=1$, tai reiškia, kad investuotojas priims sprendimą keisti portfelio sudèti tik tuo atveju, kai laukiamas pelningumo padidejjimas ivertinus visas sandorių sąnaudas bus ne mažesnis kaip patiriamos sandorių sąnaudos (optimizuoto ir esamo portfelio laukiamų pelningumų skirtumas prieš sandorių sąnaudas dvigubai viršija sandorių sąnaudas).

Taikant pasiūlytą metodą investicijų portfelio sudètis būtų atnaujinama ne kiekvienu periodu, o tik esant tam tikroms sąlygoms, taigi metodas užtikrintu Feng et al. (2011) bei Kozat ir Singer (2011) pasiūlymo keisti portfelio sudèti ne kiekvieną periodą igyvendinimą ir atitiktų Eakins ir Stansell (2007) priežastinio portfelio sudetties keitimo strategija.

Vertinant pasiūlytą sprendimo keisti portfelio sudèti prièmimo metoda, reikia pastebèti, kad jis, kaip ir kitų mokslininkų siūlomi metodai, ivvertina tik 
visiško perejjimo prie naujos sudèties (optimalaus) portfelio tikslinguma, tačiau neivertina dalinio keitimo galimybiu pasirenkant tarpini tarp esamo ir optimalaus investicijų portfelį. Sprendimas portfelio sudètị keisti iš dalies galètų būti priimamas vertinant ribines laukiamo pelningumo ir sandorių sąnaudų pokyčio reikšmes. Tokiu atveju, blogiausių esamo portfelio aktyvų būtų atsisakoma ir isigyjami geriausi optimalaus portfelio aktyvai tol, kol tenkinama nelygybė:

$$
\frac{\Delta E(R)}{\Delta C} \geq K_{\min }^{\prime},
$$

čia $\Delta \mathrm{E}(\mathrm{R})$ - ribinis laukiamo pelningumo pokytis; $\Delta \mathrm{C}$ - ribinès sandorių sąnaudos; $K_{\min }^{\prime}$ - investuotojo pasirinkta minimali ribinio laukiamo pelningumo pokyčio ir ribinių sąnaudų reikšmè, kad būtų priimtas sprendimas portfelio sudètị keisti iš dalies.

Ribinio laukiamo pelningumo pokyčio ir ribinių sąnaudų požiūrio taikymas leidžia nustatyti ir atlikti portfelio sudeties keitimus, turinčius daugiausiai įtakos laukiamai portfelio grąžai taip pat užtikrinant, kad bus atsisakyta sandorių, kurių laukiamas pelningumo pokytis tik neženkliai viršija sandorių sąnaudas. Atsižvelgiant $\mathfrak{i}$ tai, jog iš dalies keičiant rizikingų aktyvų portfelio sudèti yra pasirenkamas neoptimalus portfelis, kuris gali būti rizikingesnis ar mažiau rizikingas nei investuotojui priimtinas rizikos lygis, bendrojo portfelio rizika gali būti koreguojama keičiant finansinio sverto panaudojimo intensyvumą.

\subsection{Aktyvaus investiciju portfelio valdymo modelis}

Šio darbo 2.1-2.3 poskyriuose buvo pasiūlyti konkretūs investicijų portfelio sprendimai, taikytini aktyviai valdant investicijų portfeli, kurie apėmé apribojimų ir sąnaudų poveikio efektyviajai portfelių ribai ịvertinimą prognozių integravimo metodo, kaip prognozavimo didinimo priemonès, sukūrimą bei sprendimo keisti portfelio sudèti prièmimo metodo sukūrimą. Tačiau šiame darbe buvo detalizuoti tik tie sprendimai, kurie, darbo autoriaus nuomone, turi daugiausiai itakos portfelio rezultatams ir yra nepakankamai išnagrinèti kitu mokslininkų darbuose. Kadangi siekiant aktyviai valdyti investicijų portfeli reikia žinoti ne tik konkrečiuose etapuose taikomus sprendimus, bet ir išmanyti bendrą aktyvaus portfelio valdymo procesą, tikslinga pateikti bendrą aktyvaus portfelio valdymo procesą atskleidžianti modeli. Aktyvaus investiciju portfelio valdymo bazinis modelis pateikiamas 2.19 paveiksle. 


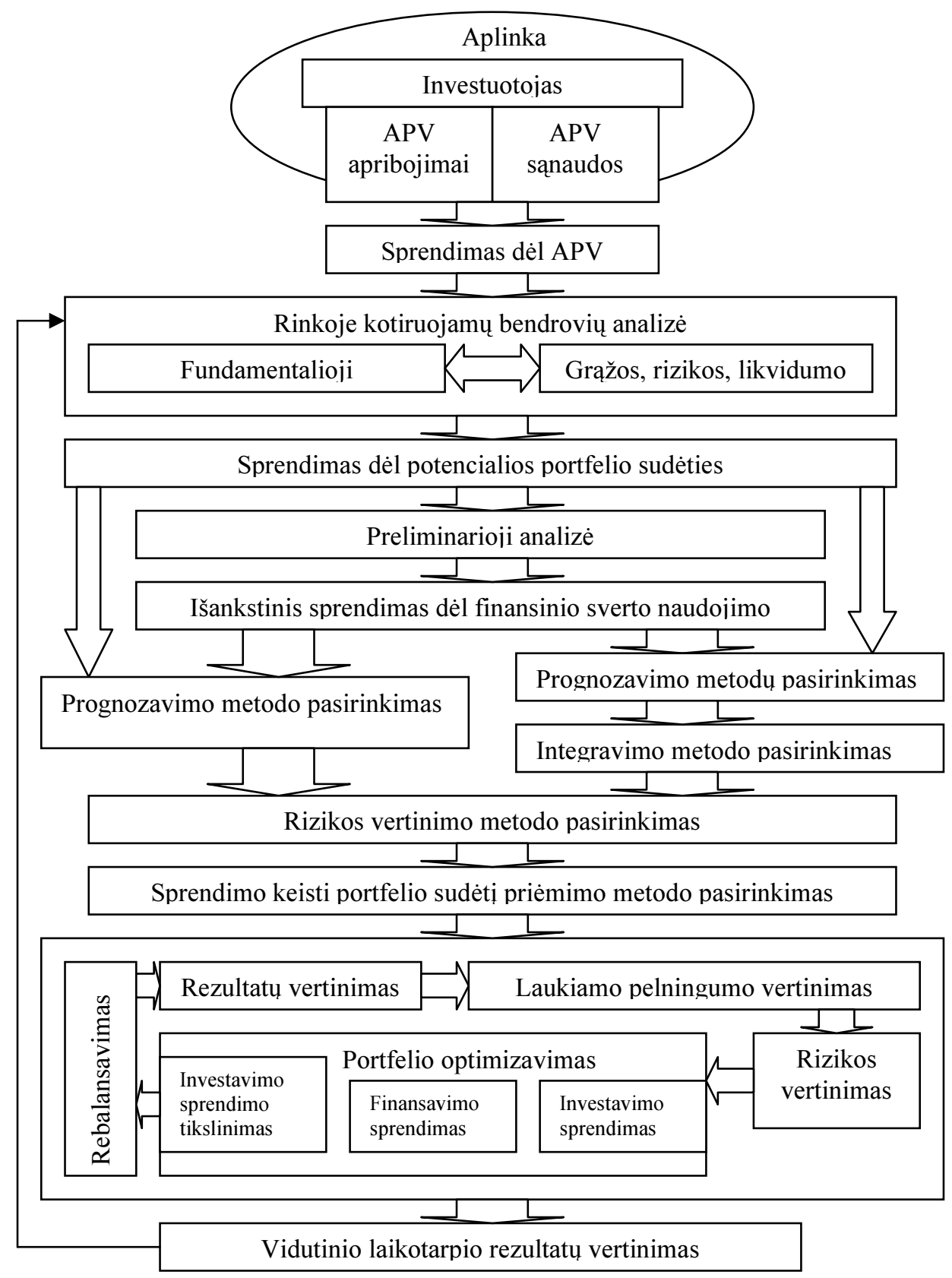

2.19 pav. Aktyvaus portfelio valdymo modelis

Fig. 2.19. Model for active portfolio management Šaltinis: sudaryta autoriaus 
2.19 paveiksle pateiktą modeli galima santykiškai suskirstyti i penkias pagrindines dalis: sprendimo aktyviai valdyti portfelį prièmima, analitinę pasirengimo valdyti portfeli fazę, metodinę pasirengimo valdyti portfelį fazę, portfelio valdymą (realią prekyba) ir monitoringą.

Investuotojo apsisprendimui aktyviai valdyti portfeli (AVP) turi itakos tiek aplinkos veiksniai, tiek makroekonominiai, tiek vertybinių popierių rinkos išsivystymo lygis, tiek ir konkretūs aktyvaus portfelio valdymo apribojimai ir sąnaudos. Investuotojas, ivvertinęs aplinkos veiksnius, aktyvaus portfelio valdymo apribojimu ir sąnaudu poveiki efektyviajai portfelių ribai bei savo polinki ir galimybes (reikalingas laiko sąnaudas, žinių pakankamumą) priima sprendimą aktyviai valdyti investicijų portfeli.

Pasirengimas investicijų portfeliui sudaryti ir valdyti prasideda nuo biržoje kotiruojamų bendrovių analizès, siekiant atrinkti geriausias bendroves, kurios potencialiai galès būti itrauktos ì optimalų investicijų portfelį. Bendrovių atrankai gali būti taip pat naudojamas šio darbo 3 skyriuje aprašytas daugiakriteris investicinio patrauklumo vertinimas. Atlikęs preliminarią akcijų grąžos svyravimų analizę, ìvertinęs nerizikingo skolinimo ir skolinimosi galimybes ir sąnaudas bei savo polinki rizikuoti investuotojas priima išankstini sprendimą dèl finansinio sverto naudojimo.

Apsisprendęs aktyviai valdyti investicijų portfelį taikant finansinį svertą ar jo netaikant, investuotojas pasirenka konkrečius metodus, kuriuos taikys portfeliui valdyti, taip pat pasirenka konkretu ar kelis prognozavimo metodus. Pasirinkus kelis metodus taip pat yra pasirenkamas juos taikant gautų prognozių integravimo metodas. Rizikai vertinti gali būti pasirinktas bet kuris iš mokslininkų siūlomų rizikos valdymo metodų - dispersija, vidutinis absoliutus nuokrypis (MAD), pusiau variacija (SV), VaR, CVaR ir pan. Metodinę pasirengimo aktyviai valdyti portfeli fazę užbaigia sprendimo keisti portfelio sudèti prièmimo metodo pasirinkimas.

Siekdamas investuoti turimas léšas investuotojas prognozuoja laukiamą rizikingu vertybinių popierių pelningumą ir riziką bei suranda optimalų investicijuc portfeli (kaip buvo minèta 2.1 poskyryje, optimalus sprendimas randamas priimant investavimo ir finansavimo sprendimus, prireikus tikslinant investavimo sprendima). Pirmaji kartą investuotojas investuoja i optimalų portfeli, vèliau kartojant ciklą yra priimamas sprendimas keisti portfelio sudèti isigyti optimalų portfeli, palikti esamą ar iš dalies atnaujinti portfelio sudeti; ir vertinami investavimo (vieno periodo) rezultatai.

Aktyviai valdant portfeli periodiškai taip pat yra vertinami vidutinio laikotarpio rezultatai ir remiantis jais prireikus yra priimamas sprendimas tikslinti modelio 2 ir 3 dalyje pasirinktus sprendimus. 


\subsection{Antrojo skyriaus išvados}

Apibendrinant šiame skyriuje atliktą analizę ir pasiūlytus konkrečius portfelio sprendimus aktyviems investuotojams galima pateikti šias išvadas ir apibendrinimus:

1. Atlikta investicijų portfelio teorijų analizè parodé, jog moderniosios portfelio teorijos pradininku turètu būti laikomas ne tik plačiai mokslininkų pripažįstamas H. Markowitz (1952), bet ir A. D. Roy (1952), kuris įvedęs minimalią pageidaujamą grąžos normą leido spręsti portfelio problemą vienareikšmiškai, o ne pasiūlant efektyviają portfelių ribą.

2. W. Sharpe $(1963,1964)$ pasiūlius derinti portfelyje rizikingus ir nerizikingus aktyvus bei sukūrus kapitalo aktyvų ikainojimo modelị, buvo ivertintas finansinio sverto taikymo poveikis efektyviajai portfelių ribai, tačiau bazinis modelis remiasi daugeliu prielaidu, kurios realiame gyvenime netenkinamos, todèl gali klaidinti investuotojus, pateikdamas geresnes, nei investuotojas galètų iš tikrujų tikètis, rizikos ir pelningumo kombinacijas.

3. Atsižvelgiant ị realios rinkos apribojimus ir atsirandančias papildomas sąnaudas dèl finansinio sverto naudojimo aktyviam portfelio valdymui, efektyvioji portfelių riba igyja sudètingesnę formą ir pasislenka i apačią, t. y. sumažèja laukiamas portfeliu pelningumas, esant tam pačiam rizikos lygiui, todèl finansinio sverto naudojimas yra naudingas tik tuomet, kai yra intensyviai naudojamasi nerizikingo skolinimo ar skolinimosi galimybėmis. Naudojant šias galimybes minimaliai, negaunama didesnès naudos nei taikant bazini $\mathrm{H}$. Markowitz modeli.

4. Atliktas finansinio sverto taikymo tikslingumo aktyviai valdant investicijų portfeli empirinis tyrimas parodè, jog esant akcijų kainų kitimams, būdingiems Lietuvos VP rinkai, investuotojas, siekdamas maksimizuoti investicijų pelninguma, turètų aktyviai naudotis nerizikingo skolinimo(si) galimybėmis: 25 proc. atvejų būtų pasirinktos vien nerizikingos investicijos, 18 proc. atvejų būtų maksimaliai išnaudotos nerizikingo skolinimosi galimybès ir tik 7 proc. atvejų būtų investuojama vien tik i rizikingus VP (palyginimui: Rutkauskas, Žilinskij (2010) analogiško tyrimo rezultatai buvo atitinkamai 11, 57 ir 7 proc.). Atsižvelgiant i toki finansinio sverto naudojimo intensyvumą ir VP pelninguma, galima teigti, jog finansinio sverto naudojimas yra tikslingas ir leidžia pasiekti geresnių pelningumo - rizikos kombinacijų negu investuojant tik nuosavas lèšas.

5. Atliekant empirini tyrimą gauti rezultatai buvo panaudoti tikslinant sumodeliuotą efektyviaja portfelių riba, kai optimaliam portfeliui pasirinkti J. Tobin pasiūlyta atskyrimo teorema nèra tinkama ir turi būti taikomas dvigubas atskyrimas: preliminaraus investavimo sprendimo priemimas; finansavimo sprendimo prièmimas; investavimo sprendimo patikslinimas. 
6. Kritinis veiksnys siekiant efektyviai aktyviai valdyti investiciju portfeli yra tikslios akcijų grąžos prognozès. Mokslinès literatūros analizè parodè, kad mokslininkai dažniausiai taiko pavienius prognozavimo metodus arba siūlo atskirų metodų integravimo galimybes. Kadangi pavienių prognozavimo metodų taikymas gali neužtikrinti prognozavimo tikslumo, o metodų integravimas yra sudètingas, gero visų integruojamų metodų suvokimo reikalaujantis procesas, buvo pasiūlytas atskirais metodais gautu prognozių integravimo metodas.

7. Prognoziu integravimo pagrindas taikant pasiūlytą metodą yra prognozavimo tikslumas praeityje, todèl jis gali būti taikomas integruojant visuc prognozavimo metodų, leidžiančių i̇vertinti praeities laikotarpių prognozavimo tiksluma, prognozes.

8. Siekiant ivvertinti pasiūlyto modelio efektyvumą jis buvo testuojamas integruojant skirtingų periodų laiko eilučių paprastojo ir svertinio slankiojo vidurkio metodais gautas prognozes. Tyrimo rezultatai parode, jog paprastojo slankiojo vidurkio atveju integruotuc prognozių vidutinès absoliučios prognozavimo paklaidos buvo mažesnès už 1 periodo neintegruotu prognozių paklaidas, prognozuojant indeksu pokyčius - 10,88 proc., akcijų grą̌ą - 9,19 proc., valiutų kursų pokyčius $-9,98$ proc.; svertinio slenkančiojo vidurkio atveju atitinkamai: 14,45 proc., 12,01 proc., 12,87 proc..

9. Aktyvus portfelio valdymas reikalauja dažnai keisti portfelio sudèti, todèl siekiant efektyviai valdyti investicijų portfeli būtina turèti investuotojo poreikius atitinkantị sprendimo keisti portfelio sudètị prièmimo metodą. Ši tema mokslinèje literatūroje nèra plačiai išnagrinèta ir daugiausia remiasi portfelio sudèties keitimo strategijų analize ar sandorių sąnaudų itraukimu skaičiuojant laukiamą portfelio pelningumą.

10. Atsižvelgiant $\mathfrak{i}$ tai, jog investuotojas keisdamas portfelio sudèti patiria realias sąnaudas dèl laukiamos (neužtikrintos) grąžos, darbe buvo pasiūlytas portfelio sudèties keitimo metodas, leidžiantis priimti sprendimus atsižvelgiant $\mathfrak{i}$ investuotojo pageidaujamą minimalų laukiamos perteklinės grą̌zos ir realiai patiriamų sąnaudų santyki, kurị taikant portfelio sudètis gali būti keičiama ne kiekvieną perioda, o tik tenkinant investuotojo nusistatytą kriterijų.

11. Net tais atvejais, kai esamo portfelio sudeti keisti pagal nusistatytą kriterijų nèra naudinga, esamame portfelyje gali būti aktyvų, kurių verta atsisakyti įtraukiant i portfeli naujus, tik iš dalies pakeičiant portfelio sudetį. Galiniam portfelio sudeties keitimo tikslingumui nustatyti darbe pasiūlytas ribinio laukiamo pelningumo pokyčių ir ribinių sąnaudų santykio kriterijus.

12. Apibendrinant ir integruojant visus šiame skyriuje pateiktus portfelio sprendimus aktyviam investuotojui buvo pasiūlytas ir trumpai aprašytas aktyvaus investicijuc portfelio valdymo modelis, apimantis visą procesą nuo apsisprendimo investuoti iki rezultatų vertinimo ir priimtų sprendimų tikslinimo. 


\section{Akciju investiciniu patrauklumu paremtas investiciju portfelis}

Šalies ar net globalios ekonomikos tvari plètra gali būti užtikrinta tik tikslingai nukreipiant turimus ribotus išteklius, investicijas i perspektyviausius ūkio sektorius ir i̇mones. Efektyvaus investavimo ir finansų rinkų misija yra užtikrinti perspektyviausių verslo sektorių plètrą ir pakankamą investicijų grąžą investuotojams. Tačiau didžioji dalis portfelio optimizavimo metodų yra orientuota $\mathfrak{i}$ sprendimų prièmimą remiantis vien akcijų kainų kitimo tendencijomis praeityje. Toks požiūris neužtikrina pakankamo investiciju efektyvumo, nes neịvertina fundamentalių, potencialią investicijų grąžą ir riziką lemiančių veiksnių poveikio. Šiame skyriuje išanalizuota daugiakriterio sprendimų prièmimo (MCDM) metodų ịvairovè ir îvertintos jų pritaikymo portfelio optimizavimo problemai spręsti galimybès, pristatytas akcijų investiciniu patrauklumu paremtas portfelio sudarymo modelis, pasiūlyti konkretūs modelio taikymo sprendimai akcijų investicinio patrauklumo ivertinimo ir portfelio optimizavimo etapuose, ivertintos prielaidos akciju investiciniu patrauklumu paremtai investicijuc portfelio sudarymo ir valdymo sprendimu paramos sistemai kurti. Šiame skyriuje atlikto akcijų investiciniu patrauklumu paremto investicijų portfelio sudarymo galimybiu ir efektyvumo tyrimo pagrindu paskelbtas straipsnis mokslo žurnale (Žilinskij, Rutkauskas 2012). 


\subsection{Daugiakriterio sprendimų prièmimo metodų ivairovè ir jų taikymo investicijų portfeliui sudaryti galimybès}

Modernioji portfelio teorija nagrineja portfelio sudarymo problemą remiantis dviem pagrindinemis charakteristikomis - laukiamu pelningumu ir rizika. $\mathrm{H}$. Markowitz ir daugelis kitu mokslininkų laukiamam pelningumui nustatyti taiko aritmetini praeities laikotarpiu grąžos vidurkị (Markowitz 1959; Tvaronavičienè, Michailova 2004; Vasiliauskaitė 2004, Bikas, Laurinavičius 2009; BaixauliSoler 2011). Mokslinejje literatūroje dažnai taikomi ir kiti laukiamo pelningumo ivertinimo metodai: paprastasis ir eksponentinis slankieji vidurkiai (Dzikevičius ir Šaranda 2010), autoregresiniai slankieji vidurkiai (Jarret ir Schilling 2008; Sallehuddin ir Shamsuddin 2007; Stevenson 2007), taip pat tokie sudètingi prognozavimo metodai, kaip neuroniniai tinklai (ANN) (Jandaghi et al. 2010; Kumar 2010; Leigh et al. 2002; Panda ir Narasimhan 2006). H. Markowitz (1952) rizikai vertinti pasiūlè naudoti dispersiją. Suabejojus dispersijos tinkamumu rizikai vertinti mokslininku darbuose buvo pasiūlyta alternatyvių rizikos vertinimo metodų: MAD (Mean Absolute Deviation), SV (Semi Variance), VaR (Value-at-Risk), CVaR (Conditional Value at Risk), ER (Expected Regret), ES (Expected Shortfall) ir kt. metodai (Byrne, Lee 2004; Tvaronavičiené, Michailova 2004; Szego 2005). Nepaisant didelès siūlomų laukiamo pelningumo ir rizikos įvertinimo metodų ịvairovès reikia pastebèti, kad jie dažniausiai remiasi vien akcijų kainos kitimo biržoje analize, visiškai neịvertinant fundamentalių imonių rodikliu̧, kurie gali turèti itakos tiek investicijų $\mathfrak{i}$ analizuojamą imonę grąžai, tiek rizikai. Fundamentalių ir net subjektyvių, tik konkrečiam investuotojui aktualių veiksnių įtraukimą i portfelio sudarymo procesą galima užtikrinti naudojant daugiakriterio sprendimų prièmimo metodus (MCDM).

E. K. Zavadsko ir Z. Turskio atliktas tyrimas parode, kad MCDM metodai vis dažniau yra taikomi ekonomikoje (Zavadskas, Turskis 2011), o Steur ir Na (2003) atliktas tyrimas parodè, kad dažniausia MCDM metodų taikymo sritis finansuose yra portfelio analizè. MCDM metoduc, kurie taikomi investicijų portfelio sudarymo problemai spręsti, yra daug. Nors dalis mokslininkų skaido MCDM metodus net i keturias grupes (Samaras, Matsatsinis 2003), tačiau šiam tyrimui atlikti tikslinga MCDM metodus analizuoti suskaidant juos $\mathfrak{i}$ dvi Bernroider ir Stick (2007) pasiūlytas pagrindines grupes:

1. Daugeli veiksnių ịvertinančius sprendimų prièmimo (MADM) metodus. Mokslininkų darbuose šios grupès metodai dažniausiai taikomi i portfelị traukiamiems aktyvams (dažniausiai akcijoms) reitinguoti (angl. ranking). Šiame darbe MADM metodų analizès pagrindu bus sudaryta kriterijų aibè ir atrinktas 
konkretus metodas akcijų investiciniam patrauklumui nustatyti (kriteriju reikšmėms agreguoti į vieną bendrą patrauklumo ịverti).

2. Daugiatikslius sprendimų prièmimo (MODM) metodus. Šie metodai tiesiogiai taikomi portfelio optimizavimo problemai spręsti. Šiame darbe jų analizè padès apsispręsti dèl portfelio optimizavimo tikslų pasirinkimo.

Mokslinèje literatūroje siūloma daug skirtingų MADM grupei priskiriamų metodu, kurie yra taikomi ekonominiams reiškiniams tirti: AHP, MAUT, UTA, UTASTAR, UTADIS, COPRAS, TOPSIS, ARAS, SAW, ELECTRE, PROMETHEE, MOORA, VIKOR, EVAMIX (Xidonas et al. 2009b; Zavadskas, Turskis 2011, Das et al. 2012). Išsamios lyginamosios visų šių metodų taikymo efektyvumo analizès nèra atlikta. Stankevičienè ir Žinytė (2011) teigia, jog SAW yra seniausias, tipinis, vienas paprasčiausių, plačiausiai žinomas ir praktiškai taikomas metodas. Podvezko (2011) lygindamas SAW ir COPRAS metodus, nustate ir matematiškai pagrindè, jog COPRAS turi svarbių savybių, leidžiančių tiksliau ỉvertinti skaičiavimų rezultatus. COPRAS metodas taip pat turi privalumų (pvz., mažas skaičiavimams reikalingas laikas, paprastumas ir skaidrumas) prieš kitus daugiakriterio vertinimo metodus, tokius kaip EVAMIX, TOPSIS, VIKOR ir AHP metodai (Das et al. 2012). Šie privalumai yra labai svarbūs, nes remiantis Tupénaité (2010) - daugelio metodų sudètingumas apriboja jų pritaikymą praktikoje.

Akcijų investiciniam patrauklumui vertinti svarbu ne tik parinkti konkretų metodą, bet ir sudaryti tinkamą vertinamų kriterijų aibę. Reikia pažymèti, kad skirtingų sektorių i̇monèms gali būti taikomi skirtingi patrauklumo vertinimo kriterijai.

Kadangi vertinant akcijų investicini patrauklumą taip pat bus analizuojami fundamentaliosios analizès kriterijai, kurių pagrindinis šaltinis yra analizuojamų imonių finansinè atskaitomybè, vien finansinès atskaitomybès skirtumai neleidžia taikyti tų pačių kriterijų pvz., finansų sektoriaus ir gamybos įmonèms (skiriasi finansinių ataskaitu struktūra, finansų sektoriaus imonèms būdingas aukštas finansinio sverto lygis, mažesnis atsargų kiekis). Šiame skyriuje kuriant ir testuojant bazini akcijų investiciniu patrauklumu paremtą portfelio optimizavimo modeli bus orientuojamasi į ne finansų sektoriaus (pvz., gamybos, prekybos ir pan.) įmones, todèl ir mokslinių šaltinių, siūlančių skirtingus kriteriju rinkinius, analizè bus orientuota i ne finansu sektoriaus imonems vertinti siūlomų kriterijų tyrimą. Skirtingų mokslininkų siūlomi kriterijai akcijoms reitinguoti/investiciniam patrauklumui nustatyti pateikiami 3.1 lentelèje. 
3.1 lentelè. Kriterijai akcijų reitingavimui/investiciniam patrauklumui nustatyti

Table 3.1. Stock ranking/investment attractiveness evaluation criteria's

\begin{tabular}{|c|c|}
\hline Šaltinis & Siūlomi taikyti kriterijai \\
\hline Huang 2012 & $\begin{array}{l}\text { Kainos pagristumo rodikliai: akcijos kainos ir pelno akcijai santykis (P/E), kainos ir buhalterinės vertès } \\
\text { santykis (P/B), kainos ir pardavimų santykis (P/S); } \\
\text { Pelningumo rodikliai: nuosavo kapitalo grąža (ROE), turto grąža (ROA), veiklos pelningumas (OPM), } \\
\text { grynasis pelningumas (NPM); } \\
\text { Finansinio sverto rodiklis: isipareigojimų ir nuosavo kapitalo santykis (D/E); } \\
\text { Likvidumo rodikliai: bendrasis likvidumas (CR), skubusis likvidumas (QR); } \\
\text { Efektyvumo rodikliai: atsargu apyvartumas (IRT), gautinų sumų apyvartumas (RTR); } \\
\text { Augimo rodikliai: veiklos pelno augimas (OIG), grynojo pelno augimas (NIG). }\end{array}$ \\
\hline $\begin{array}{l}\text { Xidonas et al. } \\
2009 a\end{array}$ & $\begin{array}{l}\text { Akcijų rinkos rodikliai: } \\
\text { grąžos matai - kapitalo grąža, dividendinis pajamingumas; } \\
\text { rizikos matai - gražos standartinis nuokrypis, beta koeficientas; } \\
\text { rinkos patrauklumo matai - paklausumas, santykinis } \mathrm{P} / \mathrm{E} \text { (metų } \mathrm{P} / \mathrm{E} / 3 \text { metų P/E vidurkis). } \\
\text { Fundamentinès analizés rodikliai: } \\
\text { grąžos matai - turto graža, nuosavo kapitalo grąža; } \\
\text { valdymo efektyvumo matai - turto apyvartumas, atsargų apyvartumas; } \\
\text { kapitalo struktūros matai - turto ir įsipareigojimų santykis (A/D), D/E. }\end{array}$ \\
\hline Chung, Kim 2001 & Iš viso 68 rodikliai: pinigu srauto rodikliai (16 rodikliu); augimo rodikliai (29); rizikos rodikliai (23). \\
\hline $\begin{array}{l}\text { Sevastjanov, } \\
\text { Dymova } 2009\end{array}$ & $\begin{array}{l}\text { Pelno akcijai (EPS) metinis pokytis, pajamų pokytis, teigiamas pelno prieš mokesčius pokytis, investicijų } \\
\text { grąžos (ROI) pokytis, akcijų skaičiaus pokytis, EPS ketvirčio pokytis, kapitalo investicijų nusidèvejjimas, } \\
\text { kapitalizacija, pelningumas prieš mokesčius, ROI, pastarojo ketvirčio EPS pokytis lyginant su paskutiniais } \\
12 \text { mėnesių; pastarojo ketvirčio pajamų pokytis lyginant su paskutiniais } 12 \text { mėnesių }\end{array}$ \\
\hline $\begin{array}{l}\text { Xidonas et al. } \\
2009 b\end{array}$ & $\begin{array}{l}\text { ROE, ROA, grynasis pelningumas, gautinų sumų mokèjimo atidèjimo terminas, mokètinų sumų mokèjimo } \\
\text { terminas, turto apyvartumas, QR, pinigų ir ekvivalentų ir trumpalaikių ísipareigojimų santykis, } \\
\text { trumpalaikių isipareigojimų ir apyvartinio kapitalo santykis, D/E, turto ir nuosavo kapitalo santykis, EBIT } \\
\text { ir palūkanų sąnaudų santykis. }\end{array}$ \\
\hline
\end{tabular}


Samaras et al. 2008 Finansinès struktūros rodikliai: nusidèvèjimas/materialusis turtas, nuosavas kapitalas/skolos (E/D), apyvartinis kapitalas/reikalavimai apyvartiniam kapitalui, apyvartinis kapitalas/trumpalaikis turtas, CR, QR, isipareigojimai/(isipareigojimai ir nuosavas kapitalas);

Valdymo efektyvumo rodikliai: turto apyvartumas, nuosavo kapitalo apyvartumas, atsargu apyvartumas dienomis, palūkanų sąnaudos/pardavimai, atsiskaitymo su tiekejjais terminas-pirkèjų atsiskaitymo terminas; Pelningumo rodikliai: bendrasis turto pelningumas, turto pelningumas prieš mokesčius, grynasis nuosavo kapitalo pelningumas, bendrasis pelningumas, veiklos pelningumas, pelningumas prieš mokesčius;

Finansavimosi politikos rodikliai: savilikvidacijos (self-liquitation)*100/pardavimai; savilikvidacijos/ilgalaikiai issipareigojimai, savilikvidacijos/investicijos.

Ehrgott et al. 2004 Graž̆os rodikliai: 12 mèn. kainos pokytis, 3 metų kainos pokytis, dividendai už metus, S\&P reitingavimas; Rizikos rodikliai: S\&P reitingavimas, standartinis nuokrypis.

Voulgaris et al. $\quad$ CR; QR; (ilgalaikès skolos + grynoji vertė)/materialusis turtas; ilgalaikès skolos/visas turtas; visi 2000 isipareigojimai/visas turtas (D/A); grynoji vertè/ilgalaikis kapitalas; trumpalaikiai įsipareigojimai/visas turtas; (atsargos*360)/pardavimai; pardavimai/materialusis turtas; NPM; grynasis pelnas/grynoji verte; grynasis pelnas/visas turtas.

Garcia et al. 2010 Trumpalaikis turtas, visas turtas, nuosavas kapitalas, apyvarta, veiklos pelnas, pelnas prieš mokesčius, grynasis metu pelnas, ROA, ROE, CR.

Tiryaki, Rinkos vertė/EBITDA, ROE, skolos/nuosavas kapitalas, CR, Rinkos vertè/pardavimai, P/E.

Ahlatcioglu 2005

Lee et al. 2009 Sektoriaus perspektyvumas, pelno paskirstymas, veiklos pinigų srautas, dividendų išmokejjimo rodiklis, rinkos beta, nerizikinga palūkanų norma, pelno augimas, dividendų išmokejjimo augimas.

Stasytytè $2011 \quad$ Akcijos kainos grafinis vaizdas: metinis akcijos kainos kitimo grafikas su 50 dienų slankiuoju vidurkiu; Fundamentalieji ir elgsenos rinkoje kriterijai: EPS, P/E, P/B, ROE, beta, akcijų skaičius, laisvai prekiaujamų akcijų skaičius, kapitalizacija, prekybos apimtis, P/S, dividendinis pajamingumas, ROA, B/S; Akcijų kainų ir jų prieaugių statistiniai parametrai: vidurkis, standartinè paklaida, moda, mediana, standartinis nuokrypis, standartinis nuokrypis nuo vidurkio (proc.), dispersija, ekscesas, asimetrija, minimali reikšmè, dienų skaičius, metinis kainos pokytis;

Koreliacinė analizè: koreliacijos koeficientai. 
Iš 3.1 lentelès matyti, kad skirtinguose mokslo darbuose siūlomi skirtingi kriterijų deriniai akcijų investiciniam patrauklumui nustatyti, taip pat pateikiamos skirtingos jų klasifikacijos. Tai parodo, jog mokslininkai nesutaria, kaip turètų būti vertinamas atskiru imonių akcijų investicinis patrauklumas. Apibendrinant 3.1 lentelèje pateiktus kriterijus ir ịvertinus jų papildymo galimybes 3.1 paveiksle yra pateikiama galima akciju investicinio patrauklumo vertinimo kriterijų klasifikacija.

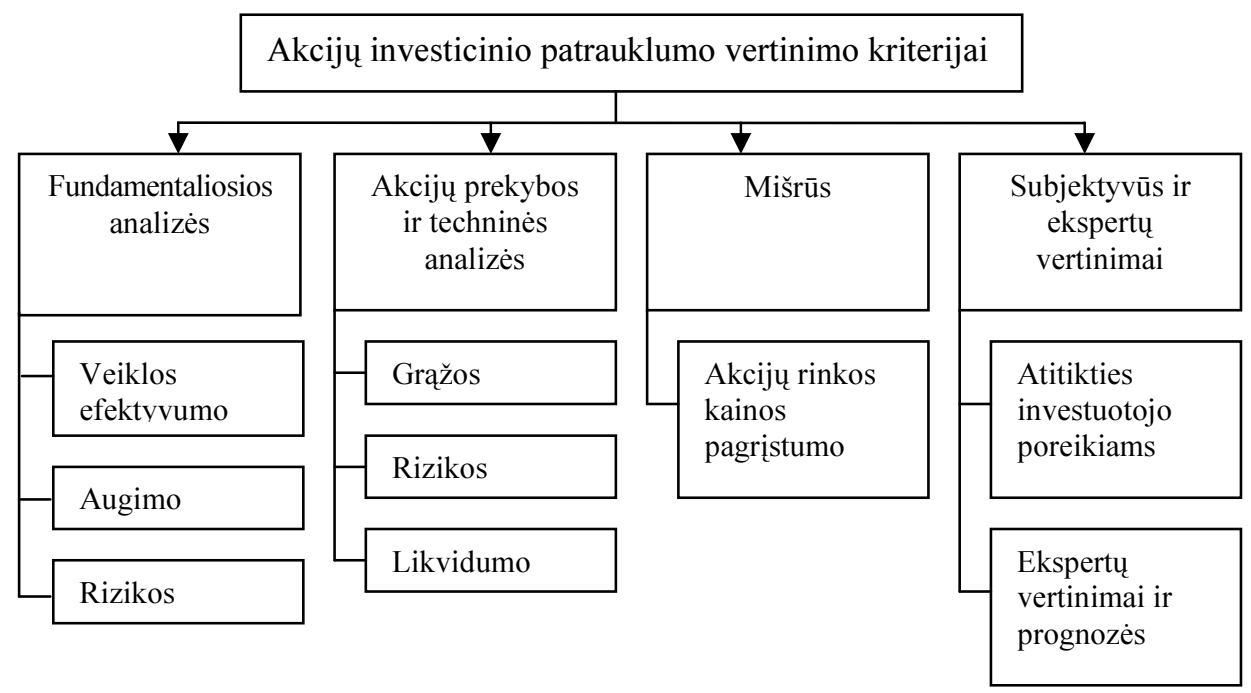

3.1 pav. Investicinio patrauklumo vertinimo kriterijų klasifikacija

Fig. 3.1. Classification of investment attractiveness evaluation criteria's Šaltinis: sudaryta autoriaus

Fundamentaliosios analizès kriterijai parodo, kaip efektyviai veikia i̇monè, kurios akcijas numatoma itraukti i portfeli, kaip intensyviai plečia veiklos apimti, ar daug turi skolų. Akcijų prekybos rinkoje ir techninès analizės kriterijai parodo, kaip investuotojai vertina imonę ir jos perspektyvas, koks akcijų kainos nepastovumo lygis, ar imonès akcijos yra pakankamai likvidžios, kad esant poreikiui jas galima būtų parduoti be didesnių nuostolių. Mišrūs kriterijai parodo, ar įmonè nèra pervertinta rinkoje (pvz., dèl susiformavusio akcijų kainų burbulo tam tikrame sektoriuje). Subjektyvūs ir ekspertų vertinimai leidžia ivertinti ekspertų ir analitikų nuomones dèl galimos akcijų grąžos, jų pateikiamas rekomendacijas, leidžia pasirinkti geriau investuotojo poreikius ir polinkius atitinkančias investicijas, tai yra ypač aktualu, kai vis daugiau mokslininku darbų (pvz., Bilbao-Terol et al. 2012; Hallerbach et al. 2004; 
Ballestero et al. 2012) skirta socialiai atsakingam, etiniam investiciju portfeliui sudaryti ir valdyti.

Nagrinejant MODM grupès metodų taikymą investicijų portfeliui sudaryti reikètu pastebèti, kad net pirminis Markowitz (1952) pasiūlytas vidurkio-dispersijos portfelio sudarymo metodas gali būti priskirtas šiai grupei, nes optimizuojant portfeli yra siekiama dviejų tikslų - maksimizuoti laukiamą grąžą ir minimizuoti riziką. Prie dvitikslių portfelių optimizavimo metodų taip pat priskiriami visi šio skyriaus pradžioje minèti Markowitz modelio patobulinimai numatant kitus laukiamo pelningumo ir/ar rizikos nustatymo būdus.

Mokslinèje literatūroje dažnai nagrinejjami trijų tikslų portfelio optimizavimo metodai. Konno et al. (1993) pasiūlè vidurkio - absoliutaus nuokrypio - asimetrijos modeli, Roman et al. (2007) - vidurkio - dispersijos CVaR modeli. Dažniausias moksliniuose šaltiniuose vidurkio - dispersijos asimetrijos modelis (Konno, Suzuki 1995; Bhattacharyya 2011; Yu et al. 2008; Li et al. 2010; Liu et al. 2003; Pindoriya et al. 2010). Anagnostopoulos ir Mamanis (2010) siūlo, be Markowitz portfeliui keliamų tikslų, taip pat siekti minimizuoti aktyvų kieki portfelyje, Lo et al. (2003) - maksimizuoti likvidumą. Prie trijų tikslų portfelio optimizavimo modelių taip pat galima priskirti Lietuvos mokslininkų pasiūlytą adekvatuji portfeli, kuris, be laukiamo pelningumo ir rizikos, taip pat atsižvelgia i patikimumą (Rutkauskas 2006; Rutkauskas, Stasytytè 2008; Rutkauskas et al. 2009; Stasytytė 2009; Stasytytė 2011).

Nors MODM metodu grupei priskiriami portfelio optimizavimo metodai dažniausiai apsiriboja trimis tikslais, bet kai kurie mokslininkai siūlo didesnị tikslų skaičių. Dalis mokslininkų siūlo modelius turinčius keturis tikslus: grąžos, rizikos, likvidumo ir tinkamumo investuotojui (Gupta et al. 2011); grąžos, santykinio dividendinio pajamingumo, vidutinio absoliutaus nuokrypio, beta koeficiento (Xidonas et al. 2011). Xidonas et al. $\left(2010^{\mathrm{b}}\right)$ taiko šešių tikslų (grąžos, dividendinio pajamingumo, vidutinio absoliutaus nuokrypio, beta koeficiento, santykinio P/E, paklausumo) modeli. Ustun ir Kasimbeyli apibendrintą vidurkio - dispersijos - asimetrijos modeli sudaro 11 tikslų, maksimizuojančių (+)/ minimizuojančių (-) šias charakteristikas: tikètiną grąžą ateityje $(+)$, vidutinę prognozavimo paklaidą $(+), 2$ skirtingų laikotarpių dispersijas (-), 2 skirtingu laikotarpių asimetrijas $(+), 12$ mèn. rezultatus $(+), 3$ metų rezultatus $(+)$, investuotojo suteiktą reitinga $(+)$, aktyvų skaičių portfelyje (-); Wilk-Shapiro testą (Ustun, Kasimbeyli 2012). Steuer et al. straipsniuose iš viso yra ịvardijama net po 12 tikslų, kurių pagrindu galètų būti optimizuojama portfelio sudetis (Steuer et al. 2005, 2007).

Vertinant mokslininku siūlomus portfelio optimizavimo tikslų rinkinius reikia pastebèti, kad kiekvienas iš papildomų tikslų sudaro prielaidas pasirinkti geriau investuotojo poreikius atitinkantị investicijų portfeli, tačiau kuo daugiau 
tikslų, tuo sudètingesnis ir sunkiau suvokiamas investuotojui yra portfelio optimizavimo procesas. Dviejų tikslų portfelio optimizavimas yra gana nesudètingas, visa efektyvių portfelių aibè gali būti pavaizduota lengvai suvokiamu grafiniu pavidalu dvimateje erdvejje. Optimizuojant trijų tikslų portfeli, efektyvioji portfelių riba gali būti vaizduojama trimačiu pavidalu, tačiau esant didesniam tikslų skaičiui efektyviają portfelių ribą nustatyti ir vaizduoti yra labai sudètinga. Atsižvelgiant i tai, portfeliui optimizuoti turètų būti naudojamos ne daugiau kaip trijų (geriausia dviejų) tikslų sistemos, o investuotojui svarbios charakteristikos naudojant MADM metodus galètų būti integruojamos i vieną bendra iverti, kurio maksimizavimas/minimizavimas ir būtų vienas iš portfelio optimizavimo tikslų.

\subsection{Bazinio akcijų investiciniu patrauklumu paremto portfelio optimizavimo modelio sudarymas}

Atlikta mokslinių šaltinių analizè parodè, kad daugiakriterio sprendimų prièmimo metodų taikymas sprendžiant portfelio sudarymo problemą yra aktualus, šia tema parengta nemažai mokslinių straipsnių. Tematikos aktualumas verčia ieškoti nauju MCDM sprendimu integravimo i portfelio sudarymo procesą galimybių. Markowitz pasiūlytas vidurkio - dispersijos modelis yra palyginti paprastas ir gerai suvokiamas investuotojams, todèl prieš siūlant akcijų investiciniu patrauklumu paremtą modeli, tikslinga panagrinèti bazini Markowitz modeli, kurio supaprastintas vaizdas pateikiamas 3.2 paveiksle.

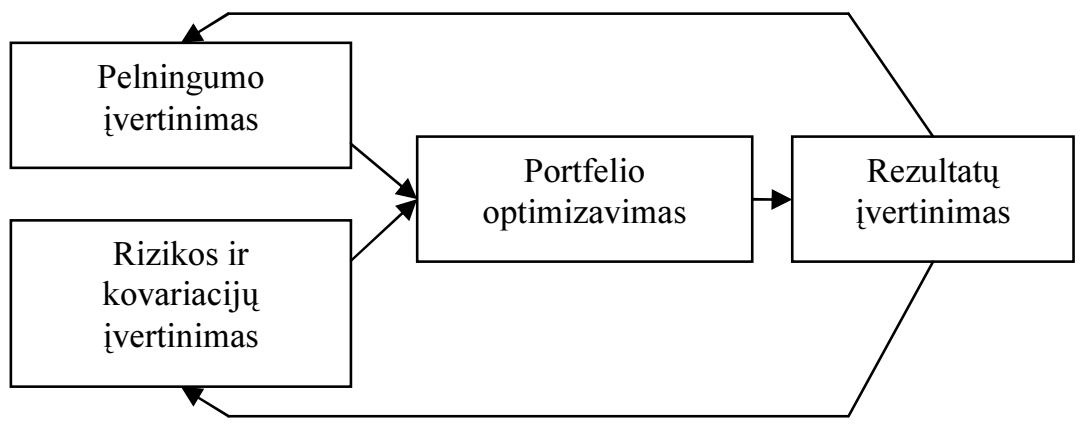

3.2 pav. Bazinis Markowitz modelis

Fig. 3.2. Basic Markowitz model

Šaltinis: sudaryta autoriaus

Kaip matyti iš 3.2 paveikslo, siekdamas sudaryti optimalų Markowitz portfeli, investuotojas privalo ivvertinti i portfelio sudèti norimų itraukti akcijų 
laukiamą pelningumą ir riziką (atskirų akcijų grąžos dispersiją ir tarpusavio kovariacijas). Šis modelis yra patrauklus savo paprastumu ir duomenų prieinamumu (laukiamas pelningumas ir rizika ivvertinami analizuojant praeities laikotarpių grąžos (akcijų rinkos kainos) svyravimus), tačiau gali klaidinti investuotojus. Finansų krizè ir sprogęs nekilnojamojo turto burbulas parodè, kad investavimas i akcijas remiantis vien jų praeities laikotarpių grąža ir neįvertinant fundamentalių imonių veiklos rodiklių gali atnešti daug nuostolių ir dažnai didžiausią nuosmuki patiria tos akcijos, kurių kainos ekonominio pakilimo laikotarpiu labiausiai augo. Tai leidžia daryti prielaida, jog nuostolių galètų padèti išvengti portfelio sudarymas, paremtas ne tik akcijų kainos rinkoje kitimo analize, bet ir fundamentalių imonès veiklos (galimos grąžos ir rizikos) rodiklių vertinimu, akcijų rinkos kainos ir fundamentalių rodiklių santykio analize. Remiantis šiuo požiūriu, pagrindinis veiksnys, lemiantis investuotojo pasirinkimą būtų ne laukiama investiciju grąža, o bendras akcijos investicinis patrauklumas, apimantis tiek grąžă, tiek riziką lemiančių veiksnių ivvertinimą. Bazinis akcijų investiciniu patrauklumu paremtas portfelio optimizavimo modelis yra pateiktas 3.3 paveiksle.

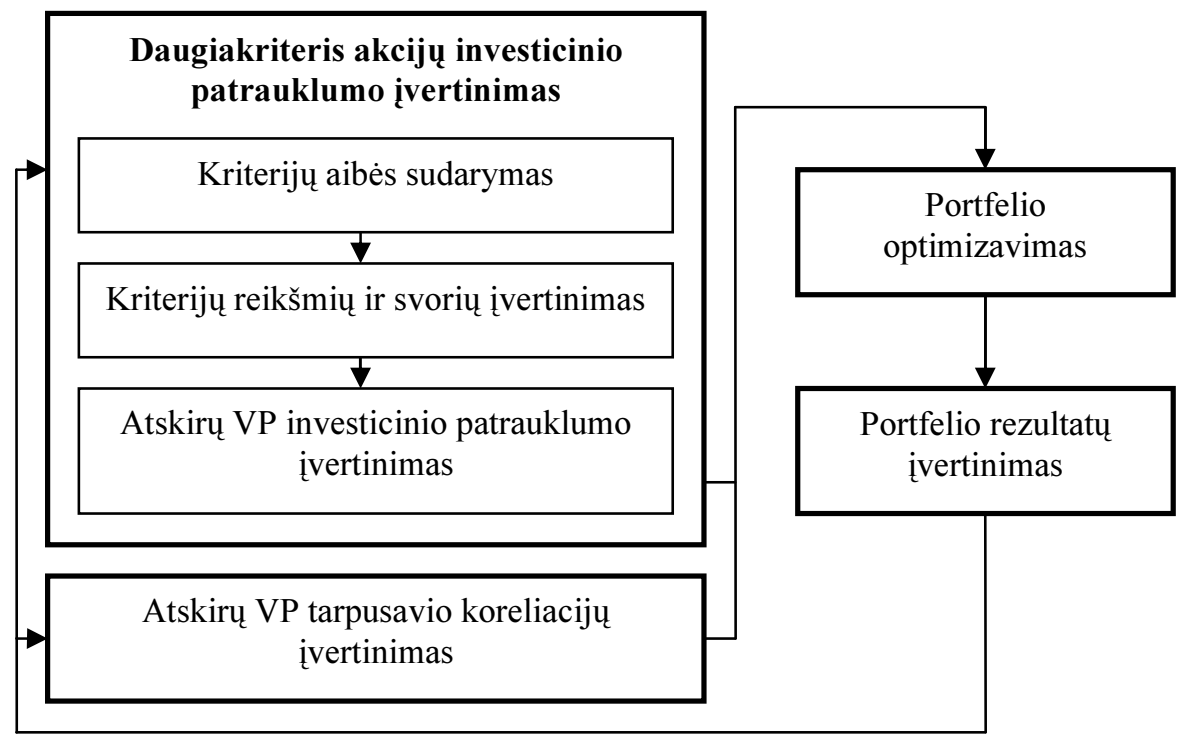

3.3 pav. Bazinis akcijų investiciniu patrauklumu paremtas portfelio optimizavimo modelis

Fig. 3.3. Basic stocks investment attractiveness based portfolio optimisation model Šaltinis: sudaryta autoriaus 
3.3 paveikslas parodo, kad siūlomas modelis, kaip ir bet kuris kitas dvitikslio portfelio optimizavimo modelis, yra labai panašus į bazini Markowitz modelị, tačiau turi vieną svaru privalumą - leidžia îvertinti daug investuotojui aktualių charakteristikų. Kiekvienas investuotojas gali savarankiškai pasirinkti, kokiais kriterijais remiantis bus vertinamas investavimo objektu (šiuo atveju akcijų) investicinis patrauklumas. Prie šių kriterijų gali būti priskiriami: akcijų kainos kitimo tendencijos, techninès analizès indikatoriai, imonès veiklos efektyvumo rodikliai, valdymo efektyvumas, santykiniai lyginamieji imonès veiklos efektyvumo ir akcijų kainos kitimo rodikliai, analitikų vertinimai, prognozès ir pan. Pastaruoju metu vis daugiau dèmesio yra skiriama imoniu socialinei atsakomybei, tad vertinant akcijų investicini patrauklumą taip pat gali būti atsižvelgiama i i̇monès socialinę, aplinkosaugos politiką, veiklos etiką. Konkrečių kriterijų ir jų svorių pasirinkimas gali skirtis priklausomai nuo investuotojo polinkių.

Vertinant akcijų investicini patrauklumą i bendra patrauklumo indeksa yra itraukiami ir rizikos veiksniai. Kadangi portfelio optimizavimas yra daugiatikslis (šiuo atveju dvitikslis) procesas, antrasis portfelio optimizavimo tikslas yra siekis minimizuoti visų i portfelio sudètị itraukiamų aktyvų tarpusavio koreliaciją (vidinę portfelio koreliacija). Minimizuojant vidinę portfelio koreliaciją siekiama nepriklausomai nuo atskirų i portfeli itraukiamų aktyvų kainų svyravimų sumažinti bendrą portfelio rinkos vertès svyravimą. Investavimo sprendimas priimamas pasirenkant geriausiai investuotojo poreikius atitinkantị investicinio patrauklumo ir vidinès portfelio koreliacijos santyki.

\subsection{Sprendimu detalizavimas ir modelio testavimas}

Ankstesniame poskyryje buvo pristatytas bazinis portfelio optimizavimo modelis (koncepcija), tačiau prieš pradedant nagrinèti modelio plètros galimybes, tikslinga ịvertinti esamo modelio efektyvumą. Modelio efektyvumas gali būti ivertintas, tik testuojant ji realiomis rinkos sąlygomis. Tačiau dar prieš testuojant modelį ir vertinant remiantis juo valdomo portfelio rezultatus, turi būti detalizuoti, pasiūlyti konkretūs modelio igyvendinimo sprendimai.

\subsubsection{Modelio sprendimų detalizavimas}

Akcijų analizei pasirinkimas. Modeliui išbandyti pasirenkamos imonès, kurių akcijos yra itrauktos i Dow Jones Industrial Average indeksą. Atsižvelgiant i tai, jog modelyje bus naudojamos tiek akcijų prekybos biržoje, tiek finansinès atskaitomybès rodikliai, i nagrinėjamų akcijų sąrašą nèra itraukiamos imonès, kurių finansiniai metai nesutampa su kalendoriniais metais, 
taip pat atsisakoma finansinio sektoriaus i̇monių ir i̇monių, kurių nèra galimybės gauti išsamių duomenų 2002-2011 m. laikotarpiu. Iš viso analizei yra atrenkama 18 įmonių:

- Alcoa Inc. (AA);

- Boeing Company (BA);

- Caterpillar, Inc. (CAT);

- Chevron Corporation (CVX);

- E.I. du Pont de Nemours and Com (DD);

- General Electric Company (GE);

- International Business Machines (IBM);

- Intel Corporation (INTC);

- Johnson \& Johnson (JNJ);

- Coca-Cola Company (KO);

- McDonald's Corporation (MCD);

- 3M Company (MMM);

- Merck \& Company, Inc. (MRK);

- Pfizer, Inc. (PFE);

- AT\&T Inc. (T);

- United Technologies Corporation (UTX);

- Verizon Communications Inc. (VZ);

- Exxon Mobil Corporation (XOM).

Kriterijų aibès sudarymas. Sudarant kriterijų aibę buvo vadovautasi šio skyriaus teorinejje dalyje atlikta kitų mokslininkų siūlomų kriterijų analize, taip pat itraukti kiti rodikliai, kurie, autoriaus nuomone, yra svarbūs investuotojams. Iš viso atliekant tyrimą bus naudojama 18 kriterijuc, jie pateikiami 3.2 lentelèje.

3.2 lentelè. Kriterijai akcijų investiciniam patrauklumui vertinti

Table 3.2. Stock investment attractiveness evaluation criteria's

\begin{tabular}{|l|l|c|l|}
\hline Nr. & Kriterijus & Poveikis * & Skaičiavimas \\
\hline 1 & Akcijų kainos pokytis & + & $\begin{array}{l}\text { Kaina (Adj. close) metu pabaigoje/kaina } \\
\text { metų pradžioje -1 }\end{array}$ \\
\hline 2 & $\begin{array}{l}\text { Imonės apyvartos } \\
\text { augimas }\end{array}$ & + & Apyvarta n metais/apyvarta n-1 metais -1 \\
\hline 3 & Veiklos pelningumas & + & Veiklos pelno ir apyvartos santykis \\
\hline 4 & EBITDA pokytis & + & EBITDA n metais/EBITDA n-1 metais -1 \\
\hline 5 & Grynasis pelningumas & + & Grynojo pelno ir apyvartos santykis \\
\hline 6 & $\begin{array}{l}\text { Veiklos sąnaudu ir } \\
\text { apyvartos santykio } \\
\text { (VSAS) pokytis }\end{array}$ & - & VSAS n metais/VSAS n-1 metais -1 \\
\hline
\end{tabular}


3.2 lentelès pabaiga

\begin{tabular}{|c|c|c|c|}
\hline$N r$. & Kriterijus & Poveikis* & Skaičiavimas \\
\hline 7 & Turto pokytis & + & $\begin{array}{l}\text { Turtas metu } \text { pabaigoje/turtas metu } \\
\text { pradžioje-1 }\end{array}$ \\
\hline 8 & $\begin{array}{l}\text { Turto apyvartumo } \\
\text { pokytis }\end{array}$ & + & $\begin{array}{l}\text { (Apyvarta } n \text { metais/ turtas } n \text { metų } \\
\text { pabaigoje)/(apyvarta } n-1 \text { metais/ turtas } n \\
\text { metų pradžioje)-1 }\end{array}$ \\
\hline 9 & $\begin{array}{l}\text { Vidutinio nuosavo } \\
\text { kapitalo gražos } \\
\text { (ROAE) pokytis }\end{array}$ & + & $\begin{array}{l}\text { ROAE n metais/ ROAE n-1 metais-1 } \\
\text { ROAE = grynasis pelnas/((nuosavas } \\
\text { kapitalas metų pradžioje }+ \text { nuosavas } \\
\text { kapitalas metu pabaigoje)/2); }\end{array}$ \\
\hline 10 & $\begin{array}{l}\text { Skolų ir nuosavo } \\
\text { kapitalo santykis }(\mathrm{D} / \mathrm{E})\end{array}$ & - & Skolos/nuosavas kapitalas \\
\hline 11 & Bendrasis likvidumas & + & $\begin{array}{ll}\text { Trumpalaikis } & \text { turtas/trumpalaikiai } \\
\text { isipareigojimai } & \end{array}$ \\
\hline 12 & $\begin{array}{ll}\text { Veiklos pinigu srauto } \\
\text { ir imonès } & \text { vertès } \\
\text { santykis } & \\
\end{array}$ & + & $\begin{array}{l}\text { Veiklos pinigu srautas/imonès } \\
\text { (kapitalizacija) }\end{array}$ \\
\hline 13 & $\begin{array}{l}\text { Akcijos kainos ir } \\
\text { buhalterinès vertès } \\
\text { santykis }(\mathrm{P} / \mathrm{B})\end{array}$ & - & $\begin{array}{l}\text { Akcijos rinkos kaina/akcijos buhalterinè } \\
\text { verté }\end{array}$ \\
\hline 14 & $\begin{array}{l}\text { Akcijos kainos ir pelno } \\
\text { akcijai santykis }(\mathrm{P} / \mathrm{E})\end{array}$ & - & $\begin{array}{l}\text { Akcijos rinkos kaina/pelnas, tenkantis } \\
\text { vienai akcijai } n \text { metais }\end{array}$ \\
\hline 15 & $\begin{array}{l}\text { Akcijų kainos pokyčio } \\
\text { standartinis nuokrypis }\end{array}$ & - & $\begin{array}{l}\text { Paskutinių } 5 \text { metų akcijos kainos metinio } \\
\text { pokyčio standartinis nuokrypis }\end{array}$ \\
\hline 16 & $\begin{array}{l}\text { Akcijų apyvartos } \\
\text { pokytis }\end{array}$ & + & $\begin{array}{l}\text { Akciju apyvarta per paskutinius } 12 \\
\text { mén./akciju apyvarta per ankstesnius } 12 \\
\text { mėn. - } 1\end{array}$ \\
\hline 17 & $\begin{array}{l}\text { Dividendinis } \\
\text { pajamingumas }\end{array}$ & + & $\begin{array}{l}\text { Išmokèta dividendų suma per paskutinius } \\
12 \text { mèn./akcijos kaina (Close) laikotarpio } \\
\text { pabaigoje }\end{array}$ \\
\hline 18 & $\begin{array}{l}\text { Akcijos } r \text { kainos } \\
\text { pokyčio ir apyvartos } \\
\text { pokyčio skirtumas } \\
\end{array}$ & - & $\begin{array}{l}\text { Akcijos kainos pokytis }- \text { imonès } \\
\text { apyvartos pokytis }\end{array}$ \\
\hline
\end{tabular}

* ženklas „,+" parodo, jog didesnè kriterijaus reikšmė didina akcijos patrauklumą (maksimizuojantis kriterijus), ,-“ parodo, jog didesnè kriterijaus reikšmė mažina akcijos patrauklumą (minimizuojantis kriterijus).

Šaltinis: sudaryta autoriaus

Kriterijų imtis sudaryta remiantis 3.1 paveiksle pateikta klasifikacija ir visus pasirinktus kriterijus galima sąlygiškai priskirti šioms kriteriju grupèms:

1. Fundamentaliosios analizès: veiklos efektyvumo $(3 ; 5 ; 6 ; 8 ; 9)$; augimo $(2 ; 4 ; 7)$; rizikos $(10 ; 11)$; 
2. Akcijų prekybos ir techninès analizès: grąžos (1; 17); rizikos (15); likvidumo (16);

3. Mišriems - akcijų rinkos kainos pagristumo kriterijams (12; 13; $14 ; 18)$.

Subjektyvaus ir ekspertų vertinimo grupès kriterijų šiame tyrime nuspręsta atsisakyti.

Metodo parinkimas akcijų investiciniam patrauklumui vertinti. Atsižvelgiant $\mathfrak{i}$ tai, kad geriausio MADM metodo pasirinkimas nèra kertinis veiksnys siekiant šiam tyrimui keliamo tikslo ir ivvertinus Podvezko (2011) ir Das et al. (2012) argumentus šio skyriaus praktinejje dalyje bus naudojamas Zavadsko ir Kaklausko (1996) pasiūlytas COPRAS metodas akcijuc investiciniam patrauklumui nustatyti.

COPRAS metodui taikyti surenkamos kiekvienos akcijos kriterijų reikšmės, kurios taikymo patogumui užtikrinti yra pateikiamos 3.3 lentelès pavidalu.

3.3 lentelè. Duomenų matrica vertinimui atlikti

Table 3.3. Data matrix for evaluation process

\begin{tabular}{|l|c|c|c|c|c|c|}
\hline \multirow{2}{*}{$\begin{array}{c}\text { Vertinimo } \\
\text { kriterijai }\end{array}$} & Poveikis & \multirow{2}{*}{ Svoriai } & \multicolumn{4}{c|}{ Pasirinktos akcijos } \\
\cline { 4 - 7 } & & & 1 & 2 & $\ldots$ & $\mathrm{j}$ \\
\hline $\mathrm{K}_{1}$ & $\check{\mathrm{z}}_{1}$ & $\mathrm{q}_{1}$ & $\mathrm{x}_{11}$ & $\mathrm{x}_{12}$ & $\ldots$ & $\mathrm{x}_{1 \mathrm{j}}$ \\
\hline $\mathrm{K}_{2}$ & $\check{\mathrm{z}}_{2}$ & $\mathrm{q}_{2}$ & $\mathrm{x}_{21}$ & $\mathrm{x}_{22}$ & $\ldots$ & $\mathrm{x}_{2 \mathrm{j}}$ \\
\hline & $\ldots$ & $\ldots$ & $\ldots$ & $\ldots$ & $\ldots$ & $\ldots$ \\
\hline $\mathrm{K}_{\mathrm{i}}$ & $\check{\mathrm{Z}}_{\mathrm{i}}$ & $\mathrm{q}_{\mathrm{i}}$ & $\mathrm{x}_{\mathrm{i} 1}$ & $\mathrm{x}_{\mathrm{i} 2}$ & $\ldots$ & $\mathrm{x}_{\mathrm{ij}}$ \\
\hline
\end{tabular}

čia $K_{i}-i$ vertinimo kriterijus; $\check{z}_{i}-i$ kriterijaus poveikio kryptis (iš 3.2 lentelès); $q_{i}-i$ kriterijaus svoris; $\mathrm{x}_{\mathrm{ij}}-\mathrm{j}$ akcijos i kriterijaus reikšmè.

Šaltinis: sudaryta autoriaus, remiantis Zavadskas, Kaklauskas (1996)

Pagal standartini COPRAS (Zavadskas, Kaklauskas 1996) metoda, siekiant užtikrinti skirtingų dydžių palyginamumą duomenys normalizuojami, transformuojant juos į bedimensę formą pagal šią formulę:

$$
\mathrm{d}_{\mathrm{ij}}=\frac{\mathrm{x}_{\mathrm{ij}} \cdot \mathrm{q}_{\mathrm{i}}}{\sum_{\mathrm{j}=1}^{\mathrm{n}} \mathrm{x}_{\mathrm{ij}}}, \quad \mathrm{i}=\overline{1, \mathrm{~m}} ; \quad \mathrm{j}=\overline{1, \mathrm{n}} \text {. }
$$

Tačiau ivvertinus tai, jog pasirinktas metodas akcijų investiciniam patrauklumui nustatyti tinkamai veikia tik esant teigiamoms vertinamų kriteriju reikšmėms, o pasirinkti kriterijai gali turèti ir neigiamų reikšmių, duomenis reikia papildomai pertvarkyti. Šiam tikslui modelyje bus naudojamos reikšmès ne tiesiogiai skaičiuojant 3.2 lentelejje pateiktų kriterijų reikšmes, bet perteklinès kriterijų reikšmès (konkrečios įmonès kriterijaus reikšmè minus minimali iš visų 
nagrinèjamų imonių kriterijų reikšmių konkrečiais metais). Taigi normalizuotos (bedimensès) kriterijų reikšmès šiame tyrime bus skaičiuojamos ne pagal 3.1, o pagal šią formulę:

$$
\mathrm{d}_{\mathrm{ij}}=\frac{\left(\mathrm{x}_{\mathrm{ij}}-x_{i \min }\right) \cdot \mathrm{q}_{\mathrm{i}}}{\sum_{\mathrm{j}=1}^{\mathrm{n}}\left(\mathrm{x}_{\mathrm{ij}}-x_{i \min }\right)}, \quad \mathrm{i}=\overline{1, \mathrm{~m}} ; \quad \mathrm{j}=\overline{1, \mathrm{n}},
$$

čia $x_{i \min }-$ minimali i kriterijaus reikšmė tarp visų akcijų.

Vykdant normalizavimą visuomet turi būti užtikrinta lygybè:

$$
\mathrm{q}_{\mathrm{i}}=\sum_{\mathrm{j}=1}^{\mathrm{n}} \mathrm{d}_{i j}, \quad \mathrm{i}=\overline{1, \mathrm{~m}} ; \mathrm{j}=\overline{1, \mathrm{n}} .
$$

Kiekvienos akcijos (j) maksimizuojančių ir minimizuojančių kriterijų reikšmių sumos $\left(\mathrm{S}_{+\mathrm{j}}\right.$ ir $\mathrm{S}_{-\mathrm{j}}$ atitinkamai) apskaičiuojamos:

$$
\mathrm{S}_{+\mathrm{j}}=\sum_{\mathrm{i}=1}^{\mathrm{m}} \mathrm{d}_{+\mathrm{ij}} ; \quad \mathrm{S}_{-\mathrm{j}}=\sum_{\mathrm{i}=1}^{\mathrm{m}} \mathrm{d}_{-\mathrm{ij}}, \quad \mathrm{i}=\overline{1, \mathrm{~m}} ; \mathrm{j}=\overline{1, \mathrm{n}} \text {. }
$$

Akcijos investicinis patrauklumas nustatomas integruojant maksimizuojančių ir minimizuojančių kriteriju reikšmių sumas. Santykinis j akcijos investicinis patrauklumas $\mathrm{Q}_{\mathrm{j}}$ apskaičiuojamas pagal formulę:

$$
Q_{j}=S_{+j}+\frac{S_{-m i n} \cdot \sum_{j=1}^{n} S_{-j}}{S_{-j} \cdot \sum_{j=1}^{n} \frac{S_{-m i n}}{S_{-j}}}, j=\overline{1, n} .
$$

Kuo didesnè yra $\mathrm{Q}_{\mathrm{j}}$ reikšmė, tuo patrauklesnè investiciniu požiūriu yra $\mathrm{j}$ akcija (Zavadskas, Kaklauskas 1996).

Kriterijų reikšmių nustatymas. Kriterijų reikšmėms nustatyti bus naudojami du pagrindiniai informacijos šaltiniai - nagrinejjamų imonių finansinès ataskaitos ir duomenys apie akcijų prekybą rinkoje. Atsižvelgiant $\mathfrak{i}$ finansinès atskaitomybès informacijos vèlavimą ir siekiant adekvačiai ìvertinti modelio efektyvumą darbe pasirinktas sprendimo prièmimo ir akcijų prekybos duomenų analizès momentas yra pirmoji balandžio mènesio darbo diena (pvz. metų pelnas imamas už kalendorinius metus, o akcijų kainos pokytis - nuo vienų metų balandžio 1 iki kitų metų balandžio $1 \mathrm{~d}$.).

Kriterijų reikšmių koregavimas. Skaičiuojant kriterijų reikšmes taip pat buvo susidurta su keliais atvejais, kurie pareikalavo tikslinti skaičiavimus, nes tiesiogiai taikant 3.2 lenteleje aprašytus skaičiavimus būtų iškreipti analizès rezultatai:

- Neigiamas n-1 metų pelnas skaičiuojant ROAE pokyti - gaunama neigiama rodiklio reikšmé, kai i̇monei pavyksta atsikratyti nuostolio ir gauti pelno. Esant tokiai situacijai ROAE pokyčiui skaičiuoti buvo taikoma formulè: 


$$
\triangle R O A E^{\prime}=-\frac{R O A E_{n}-R O A E_{n-1}}{R O A E_{n-1}} .
$$

- Neigiamas grynasis pelnas skaičiuojant P/E santyki. Kadangi šis kriterijus taikomas akcijos kainos pagristumui nustatyti, neigiamas (ypač mažas) grynasis pelnas iškreipia analizès rezultatus, todèl esant nuostoliui yra skaičiuojama pagal formulę:

$$
P / E^{\prime}=P / E_{\max }-\frac{P / E_{\max }}{P / E},
$$

čia $P / E_{\max }-$ maksimali iš visų analizuotų akcijų $\mathrm{P} / \mathrm{E}$ rodiklio reikšmių.

- Neigiamas nuosavas kapitalas skaičiuojant P/B ir D/E. Skaičiuojama pagal formules:

$$
\begin{aligned}
& P / B^{\prime}=P / B_{\max }-\frac{P / B_{\max }}{P / B} ; \\
& D / E^{\prime}=D / E_{\max }-\frac{D / E_{\max }}{D / E},
\end{aligned}
$$

čia $P / B_{\max }$ ir $D / E_{\max }$ maksimalios iš visų analizuotų atitinkamai $\mathrm{P} / \mathrm{B}$ ir $\mathrm{D} / \mathrm{E}$ rodiklių reikšmių.

Kriterijų svorių nustatymas. Nustatant kriterijų svorius svarbu atskirti rizikos kriterijus. Proporcijos tarp svorių, skiriamų rizikos ir kitiems kriterijams, priklauso nuo investuotojo rizikos tolerancijos lygio. Šiam pilotiniam tyrimui atlikti bus sudaryti du portfeliai, atitinkantys skirtingą rizikos tolerancijos lygi turinčių investuotojų poreikius. Numatoma, kad labiau linkę rizikuoti investuotojai rizikos kriterijams skirs 20 proc. svorio, o rizikos vengiantys investuotojai - 40 proc. Pusè rizikai skiriamo svorio yra skiriama akcijos kainos pokyčio standartiniam nuokrypiui, po ketvirtadali D/E ir bendrajam likvidumui, užtikrinant paritetą tarp akcijų kainos svyravimo rizikos ir fundamentalių rizikos veiksnių.

Kitų kriterijų svoriai bus apskaičiuojami:

1. naudojant „Microsoft Excel“ funkciją „Solver" nustatomi trejų ankstesnių metų kriterijų svoriai, kurie užtikrina aukščiausią akcijos patrauklumo ir akcijų grąžos koreliaciją. Tikslo funkcija yra:

$$
\begin{array}{r}
\max f(q)=\operatorname{corr}\left(Q_{j} ; R_{j}\right), \\
\text { kai: } \sum_{i=1}^{m} q_{i}=1, \\
q_{i} \geq 0, \quad i=\overline{1, m} ;
\end{array}
$$


2. testuojamo laikotarpio kriterijų svoriai $q_{i}^{t}$ bus lygūs trejų ankstesnių metų didžiausią koreliaciją užtikrinusių kriterijų svorių vidurkiui:

$$
q_{i}^{t}=\left(q_{i}^{t-1}+q_{i}^{t-2}+q_{i}^{t-3}\right) / 3, \quad i=\overline{1, m} .
$$

Vidinès portfelio koreliacijos skaičiavimas. Vidinè portfelio koreliacija apskaičiuojama pagal šią formulę:

$$
\operatorname{corr}_{p}=\sum_{i=1}^{N} \sum_{j=1}^{N} w_{i} w_{j} \operatorname{corr}_{i j},
$$

čia $\operatorname{corr}_{\mathrm{p}}$ - vidinè portfelio koreliacija; $\mathrm{w}_{\mathrm{i}}, \mathrm{w}_{\mathrm{j}}$ - atskirų akcijų svoriai portfelyje, $\operatorname{corr}_{i j}-$ akcijų $\mathrm{i}$ ir j kainos pokyčio rinkoje tarpusavio koreliacijos koeficientas.

Formulèje taikomas akcijų kainų pokyčio koreliacijos koeficientas skaičiuojamas pagal paskutinių 36 mènesių mėnesinius kainų pokyčius rinkoje.

Portfelio optimizavimas. Portfelis optimizuojamas maksimizuojant portfelio investicini patrauklumą esant konkrečiam investuotojui priimtinam vidinès koreliacijos lygiui $\mathrm{C}$ :

$$
\begin{gathered}
\max f(w)=\sum_{j=1}^{N} w_{j} Q_{j}, \\
\text { kai: } \operatorname{corr}_{p}=\sum_{i=1}^{N} \sum_{j=1}^{N} w_{i} w_{j} \operatorname{corr}_{i j}=C, \\
\sum_{j=1}^{N} w_{j}=1, \\
w_{j} \geq 0, \quad j=\overline{1, N} .
\end{gathered}
$$

\subsubsection{Modelio išbandymas}

Investicijų portfelio valdymo efektyvumas gali būti vertinimas tik lyginant jo rezultatus su kitais būdais valdomų portfelių rezultatais. Atliekant tyrimą buvo sudaryti du pagal pasiūlytą modelį valdomi investicijų portfeliai, skirti skirtingą rizikos tolerancijos lygi turintiems investuotojams: $\mathrm{P}(80 / 20)$, kuri rinksis labiau linkę rizikuoti investuotojai, ir $\mathrm{P}(60 / 40)$, kuri rinksis rizikos vengiantys investuotojai; taip pat du lyginamieji portfeliai - portfelis $\mathrm{P}$ (bazinis), kuriame visos analizuotos akcijos turi vienodus svorius, ir portfelis, sudarytas pagal Markowitz modeli P(Markowitz). Taikant Markowitz modeli laukiamas pelningumas yra lygus penkerių paskutiniujų metų pelningumų vidurkiui, o rizika - penkeriu paskutiniujų metu grąžos standartiniam nuokrypiui. Taikant Markowitz modeli arba pasiūlytą akcijų investiciniu patrauklumu paremtą modeli yra gaunamas ne vienareikšmis portfelio optimizavimo problemos 
sprendimas, bet efektyvioji portfelių riba. Siekiant, kad lyginimas būtu korektiškas, konkretus portfelis iš efektyviosios portfelių ribos bus pasirenkamas remiantis šiais principais:

$$
\begin{gathered}
\operatorname{corr}_{P(80 / 20)}, \operatorname{corr}_{P(60 / 40)}=\operatorname{corr}_{P(\text { bazinis })} ; \\
S D_{P(\text { Markowitz })}=S D_{P(\text { bazinis })},
\end{gathered}
$$

čia SD - portfelio standartinis nuokrypis.

Atliekant tyrimą buvo analizuotas 2002 - 2012 m. (iki 2012-04-01) laikotarpis. 2002 - 2005 metų laikotarpis buvo reikalingas modelio parametrams (kriterijų reikšmėms ir svoriams nustatyti), o nuo 2006 metų balandžio 1 dienos prasidèjo realus modelio testavimas. Tyrime naudotos kriterijų reikšmès yra pateikiamos G-O prieduose.

Portfeliams $\mathrm{P}(80 / 20)$ ir $\mathrm{P}(60 / 40)$ sudaryti taikyti kriteriju svoriai, nustatyti remiantis 3.10 ir 3.11 formulemis, pateikiami atitinkamai 3.4 ir 3.5 lentelèse.

3.4 lentelè. Portfeliui $\mathrm{P}(80 / 20)$ sudaryti taikyti kriterijų svoriai, $\%$

\begin{tabular}{|c|c|c|c|c|c|c|}
\hline \multirow{2}{*}{$\begin{array}{c}\text { Kriterijaus } \\
\text { Nr. }\end{array}$} & \multicolumn{6}{|c|}{ Investavimo periodas } \\
\hline & $\begin{array}{l}2006-04- \\
2007-04\end{array}$ & $\begin{array}{l}2007-04- \\
2008-04\end{array}$ & $\begin{array}{l}2008-04- \\
2009-04\end{array}$ & $\begin{array}{l}2009-04- \\
2010-04\end{array}$ & $\begin{array}{l}\text { 2010-04 - } \\
2011-04\end{array}$ & $\begin{array}{l}\text { 2011-04 - } \\
2012-04\end{array}$ \\
\hline 1 & 0,97 & 0,97 & 0,00 & 15,28 & 15,28 & 17,33 \\
\hline 2 & 0,00 & 1,71 & 1,71 & 1,71 & 0,00 & 0,00 \\
\hline 3 & 0,00 & 0,00 & 0,00 & 0,00 & 0,00 & 0,00 \\
\hline 4 & 0,04 & 0,00 & 0,00 & 0,00 & 0,00 & 0,00 \\
\hline 5 & 0,00 & 0,00 & 0,00 & 2,47 & 2,47 & 2,47 \\
\hline 6 & 7,23 & 3,89 & 0,00 & 0,00 & 0,00 & 0,00 \\
\hline 7 & 13,15 & 19,90 & 19,90 & 6,75 & 0,00 & 0,00 \\
\hline 8 & 3,78 & 3,78 & 0,00 & 2,34 & 2,34 & 2,34 \\
\hline 9 & 9,10 & 9,10 & 7,75 & 0,00 & 0,00 & 0,00 \\
\hline 10 & 5,00 & 5,00 & 5,00 & 5,00 & 5,00 & 5,00 \\
\hline 11 & 5,00 & 5,00 & 5,00 & 5,00 & 5,00 & 5,00 \\
\hline 12 & 6,31 & 7,83 & 1,53 & 1,53 & 0,00 & 22,88 \\
\hline 13 & 16,97 & 7,82 & 5,77 & 1,13 & 1,13 & 1,42 \\
\hline 14 & 3,03 & 3,60 & 0,57 & 0,57 & 1,91 & 2,82 \\
\hline 15 & 10,00 & 10,00 & 10,00 & 10,00 & 10,00 & 10,00 \\
\hline 16 & 0,00 & 6,84 & 6,84 & 6,84 & 0,00 & 0,55 \\
\hline 17 & 0,00 & 6,50 & 6,50 & 11,94 & 5,44 & 5,44 \\
\hline 18 & 19,42 & 8,05 & 29,43 & 29,43 & 51,42 & 24,75 \\
\hline
\end{tabular}

Table 3.4. Weights of each criteria used for portfolio $\mathrm{P}(80 / 20)$ selection, $\%$

Saltinis: sudaryta autoriaus 
3.5 lentelè. Portfeliui $\mathrm{P}(60 / 40)$ sudaryti taikyti kriterijų svoriai, \%

Table 3.5. Weights of each criteria used for portfolio $\mathrm{P}(60 / 40)$ selection, $\%$

\begin{tabular}{|c|c|c|c|c|c|c|}
\hline \multirow{2}{*}{$\begin{array}{c}\text { Kriterijaus } \\
\text { Nr. }\end{array}$} & \multicolumn{7}{|c|}{ Investavimo periodas } \\
\cline { 2 - 7 } & $\mathbf{2 0 0 6 - 0 4}-$ & $\begin{array}{c}\mathbf{2 0 0 7 - 0 4}- \\
\mathbf{2 0 0 7 - 0 4}\end{array}$ & $\mathbf{2 0 0 8 - 0 4}-$ & $\mathbf{2 0 0 9 - 0 4}-$ & $\mathbf{2 0 1 0 - 0 4}-$ & $\mathbf{2 0 1 1 - 0 4}-$ \\
$\mathbf{2 0 0 - 0 4}$ & $\mathbf{2 0 0 9 - 0 4}$ & $\mathbf{2 0 1 0 - 0 4}$ & $\mathbf{2 0 1 1 - 0 4}$ & $\mathbf{2 0 1 2 - 0 4}$ \\
\hline 1 & 0,00 & 0,00 & 0,00 & 13,02 & 13,02 & 15,81 \\
\hline 2 & 0,00 & 1,70 & 1,70 & 1,70 & 0,00 & 0,00 \\
\hline 3 & 0,00 & 0,00 & 0,00 & 0,00 & 0,00 & 0,00 \\
\hline 4 & 0,00 & 0,00 & 0,00 & 0,00 & 0,00 & 0,00 \\
\hline 5 & 0,00 & 0,00 & 0,00 & 0,70 & 0,70 & 0,70 \\
\hline 6 & 4,45 & 3,97 & 0,00 & 0,00 & 0,00 & 0,00 \\
\hline 7 & 8,09 & 14,15 & 14,15 & 6,07 & 0,00 & 0,00 \\
\hline 8 & 3,50 & 3,50 & 0,00 & 2,67 & 2,67 & 2,67 \\
\hline 9 & 0,00 & 0,00 & 0,00 & 0,00 & 0,00 & 0,00 \\
\hline 10 & 10,00 & 10,00 & 10,00 & 10,00 & 10,00 & 10,00 \\
\hline 11 & 10,00 & 10,00 & 10,00 & 10,00 & 10,00 & 10,00 \\
\hline 12 & 4,61 & 5,96 & 1,35 & 1,35 & 0,00 & 16,23 \\
\hline 13 & 20,81 & 17,63 & 13,64 & 2,61 & 0,89 & 1,87 \\
\hline 14 & 3,73 & 5,42 & 1,69 & 1,69 & 0,00 & 0,00 \\
\hline 15 & 20,00 & 20,00 & 20,00 & 20,00 & 20,00 & 20,00 \\
\hline 16 & 0,00 & 3,74 & 3,74 & 3,74 & 0,00 & 0,00 \\
\hline 17 & 0,00 & 3,73 & 3,73 & 6,45 & 2,72 & 2,72 \\
\hline 18 & 14,82 & 0,20 & 20,00 & 20,00 & 40,00 & 20,00 \\
\hline
\end{tabular}

Šaltinis: sudaryta autoriaus

Iš 3.4 ir 3.5 lentelių matyti, jog nè vienam portfeliui sudaryti nè vienais metais nebuvo panaudotas vienas kriterijus - veiklos pelningumas, ir tik vienu atveju minimaliai buvo panaudotas EBITDA pokytis, tai reškia kad šių kriterijų neįtraukimas i analizę neturètų reikšmingos įtakos jos rezultatams. Tai gali būti paaiškinta tuo, jog daugiau kaip pusę visų analizuotų kriterijų sudarè fundamentaliosios analizès kriterijai ir dalis jų iš dalies galejo dubliuoti kitus kriterijus (pvz., veiklos pelningumas gali būti susijęs su grynuoju pelningumu, kuri investuotojai labiau vertina priimdami sprendimus). Didžiausius svorius analizuotais laikotarpiais (vidutiniškai 27,09 proc. $\mathrm{P}(80 / 20)$ ir 19,17 proc. $\mathrm{P}(60 / 40)$ portfelių atveju) turejo akcijos kainos pokyčio ir apyvartos pokyčio skirtumo kriterijus, t.y. kriterijus, parodantis akcijų kainų kitimo rinkoje tendencijų atitikti imonès veiklos apimties plètrai.

Portfeliu $\mathrm{P}(80 / 20), \mathrm{P}(60 / 40)$ ir $\mathrm{P}($ Markowitz) optimizavimo rezultatai (optimalios portfeliu sudetys) pateikiamos $\mathrm{P}$ priede.

Portfelių vertès kitimai 2006-04-01-2012-04-01 laikotarpiu yra pateikti 3.4 paveiksle. 


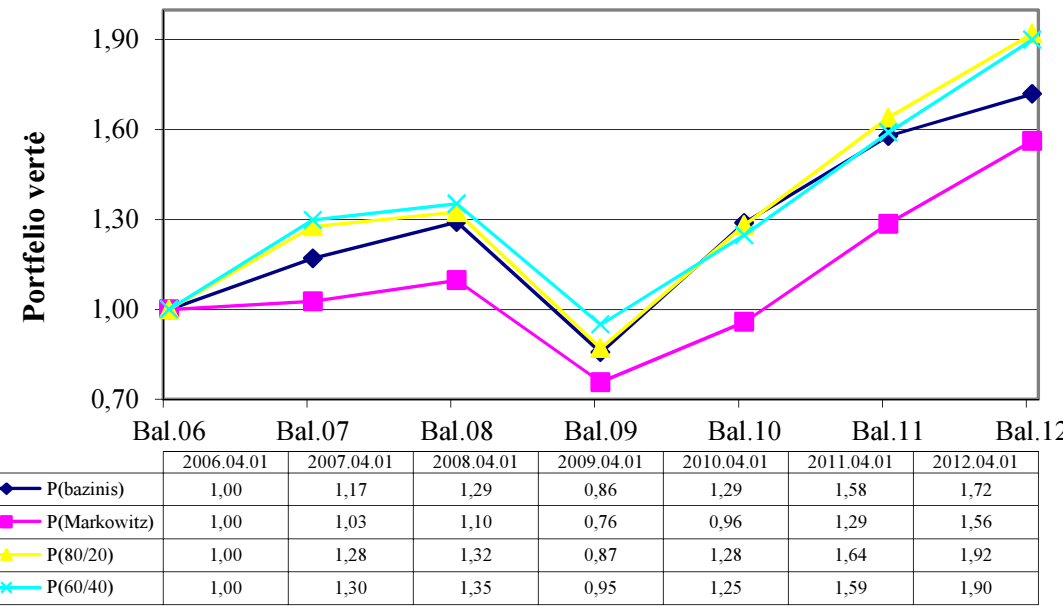

3.4 pav. Portfelių vertès kitimas

Fig. 3.4. Portfolio value changes

Šaltinis: sudaryta autoriaus

Iš 3.4 paveikslo matyti, jog investavimo pradžioje ( $2006 \mathrm{~m}$. balandžio $1 \mathrm{~d}$.) kiekvieno investicijų portfelio verte buvo lygi vienetui, o bandomojo laikotarpio pabaigoje $(2012 \mathrm{~m}$. balandžio $1 \mathrm{~d}$.) portfelių, valdytu pagal pasiūlytą modeli, vertè būtų apie 1,9, o Markowitz ir bazinio lyginamojo portfelio (lygiomis dalims) vertès būtų atitinkamai tik 1,56 ir 1,72. Kiekvieno laikotarpio portfelių grąža pateikta 3.6 lentelèje.

3.6 lentelè. Portfelių grąža analizuotu laikotarpiu, \%

Table 3.6. Return of the portfolios in the analysed period, $\%$

\begin{tabular}{|l|c|c|c|c|c|c|c|c|}
\hline \multirow{2}{*}{ Portfelis } & \multicolumn{6}{|c|}{ Metai } & Grąžos & Rizika \\
\cline { 2 - 9 } & $\mathbf{2 0 0 6}$ & $\mathbf{2 0 0 7}$ & $\mathbf{2 0 0 8}$ & $\mathbf{2 0 0 9}$ & $\mathbf{2 0 1 0}$ & $\mathbf{2 0 1 1}$ & vidurkis & (SD) \\
\hline P(bazinis) & 16,70 & 10,41 & $-33,75$ & 50,60 & 22,45 & 8,89 & 12,55 & 27,29 \\
\hline P(Markowitz) & 2,71 & 6,84 & $-31,03$ & 26,59 & 34,23 & 21,42 & 10,13 & 23,41 \\
\hline $\mathrm{P}(80 / 20)$ & 27,66 & 3,78 & $-34,31$ & 47,24 & 27,95 & 17,13 & 14,91 & 28,03 \\
\hline $\mathrm{P}(60 / 40)$ & 29,82 & 4,20 & $-29,83$ & 31,49 & 27,43 & 19,48 & 13,77 & 23,59 \\
\hline
\end{tabular}

Šaltinis: sudaryta autoriaus

Iš 3.6 lentelès matyti, jog nei vienam iš analizuotų portfelių nepavyko išvengti nuostolių 2008-04-01-2009-04-01 laikotarpiu, t. y. per pati akcijų rinkos nuosmukį dèl finansų krizès. Mažiausią nuosmukị patyrè mažesnès 
rizikos portfelis, valdomas pagal pasiūlytą modelị. Rizikuoti nelinkusio investuotojo faktinès grąžos standartinis nuokrypis tik neženkliai $(0,18$ proc.) viršijo Markowitz portfelio analogišką rodiklį bet leido pasiekti vidutiniškai 3,76 proc. didesnę metinę grąžą ir buvo pelningesnis net už faktiškai gerokai rizikingesnį bazinị lyginamaji portfelị. Geriausią grąžą analizuojamu laikotarpiu turejo pagal pasiūlytą modelị valdomas didesnès rizikos portfelis $(\mathrm{P}(80 / 20))$, tačiau jo vertès svyravimai irgi buvo didžiausi iš visų analizuotų portfelių. Vertinant portfelių rizikos ir grąžos santykį, reikia pastebėti, kad portfelio variacijos koeficientai (rizika tenkanti 1 grąžos vienetui) yra: $\mathrm{P}$ (bazinis) - 2,17; $\mathrm{P}($ Markowitz) - 2,31; $\mathrm{P}(80 / 20)-1,88 ; \mathrm{P}(60 / 40)$ - 1,71, t. y. pagal pasiūlytą modeli valdomų portfelio rizikos ir pelno santykis yra geresnis nei lyginamujų Markowitz ir bazinio - portfelių.

Testuojant modeli gauti rezultatai leidžia teigti, kad pasiūlytas akcijuc investiciniu patrauklumu paremtas investicijų portfelio sudarymo modelis yra efektyvus ir leidžia pasiekti geresnių rezultatų nei Markowitz portfelis ar portfelis, sudarytas lygiomis dalimis iš visų analizuotų akcijų.

\subsection{Akcijų investiciniu patrauklumu paremto portfelio sprendimų paramos sistemos sukūrimo gairès}

Šio skyriaus antrajame poskyryje buvo pristatytas bazinis (konceptualusis) akcijų investiciniu patrauklumu paremtas investicijų portfelio sudarymo modelis, kurio testavimas parodè, jog sudarant portfeli remiantis pasiūlytu modeliu galima pasiekti geresnius rezultatus nei Markowitz ar lygiomis dalimis sudaryto portfelio rezultatai. Tačiau bazinis modelis ir jo taikymo apribojimai (sugaištama laiko renkant duomenis, duomenų vèlavimai, prastas monitoringas ir pan.) neleidžia maksimizuoti investiciniu patrauklumu paremto portfelio koncepcijos taikymo naudos. Šiuos apribojimus panaikinti ar minimizuoti jų poveiki galetų tik integruota akcijų investiciniu patrauklumu paremto portfelio sprendimų paramos sistema.

Sprendimų paramos sistemų kūrimas pastaruoju metu tampa vis populiaresnis mokslinių tyrimų objektas, siūlomos tiek tiesiogiai portfelio sudarymo problemai spręsti skirtos sistemos (Stasytyte 2011; Xidonas et al. 2011; Beraldi et al. 2011; Dong et al. 2004), tiek susijusių sričių - daugiakriterio akciju vertinimo (reitingavimo) (Samaras et al. 2008; Samaras, Matsatsinis 2003), asmeninių finansu valdymo, iskaitant investavimą (Vahidov, He 2009, 2010). Dong et al. (2004) pasiūlè internetinès prieigos sprendimų paramos sistema, apimančią turto pasirinkimo, vertybinių popierių analizès, vertybinių popierių pasirinkimo, portfelio optimizavimo ir sudeties keitimo etapus, kur portfelis optimizuojamas taikant vieno ar kelių laikotarpių vidurkio - dispersijos 
optimizavimo modelius. Beraldi et al. (2011) sukūrè trijų pakopų scenarijų medžiu paremtą strateginio turto paskirstymo sprendimų paramos sistema, suteikiančią galimybę investuotojui nustatyti reikalavimus scenarijams kurti ir strateginio turto paskirstymo optimizavimo modeliui, užtikrinančią grižtamaji ryši i statistinio ir optimizavimo modelių sudarymo bei scenarijų kūrimo etapus. Portfelis optimizuojamas taikant vidurkio - rizikos (CVaR) modelị (Belardi et al. 2011). Xidonas et al. (2011) pasiūlè daugiatikslę (grąžos ir dividendinio pajamingumo maksimizavimo bei vidutinio absoliutaus nuokrypio ir beta minimizavimo) portfelio sudarymo sprendimu paramos sistemą. Stasytytė (2011) plètojo Rutkausko (2005a; 2005b) pasiūlytą investicijų portfelio sprendimų paramos sistema, kurioje numatytas trijų charakteristikų (gražzos, rizikos ir patikimumo) vertinimas, ir leidžiančią investuotojui priimant sprendimus rinktis iš septynių investavimo strategijų. Pagrindinis sistemos, kurios sukūrimo gairès nustatomos šiame darbe, išskirtinumas yra tai, jog ji remiasi pasiūlytu nauju akcijų investiciniu patrauklumu paremto portfelio sudarymo modeliu, t. y. joje sukaupta informacija ir jos apdorojimo galimybès leis investuotojui pasirinkti patraukliausias, labiausiai jo poreikius atitinkančias akcijas.

Butkevičius (2008) teigia, kad sprendimu paramos sistemą sudaro trys pagrindiniai komponentai: duomenys (duomenu baze ir jos valdymo sistema); modeliai (modelių bazė ir jų valdymo sistema); sąsaja (vartotojo sąsaja ir sąsaja su kitomis sistemomis). Siekiant sistemos funkcionalumo ir užtikrinti atitiktị vartotojų poreikiams yra aktualūs keli minètiems komponentams įtakos turintys aspektai:

- operatyvus patikimų duomenų surinkimas;

- duomenų apdorojimo galimybès;

- $\quad$ sprendimu priemimas ir monitoringas.

\subsubsection{Duomenų patikimumo ir surinkimo operatyvumo užtikrinimas}

Tinkamą investavimo sprendimų prièmimą gali užtikrinti tik operatyvus duomenu gavimas ir jų patikimumas. Testuojant bazini modeli duomenys buvo renkami ir sisteminami rankiniu būdu - tam reikia daug laiko, kurio investuotojams dažnai trūksta. Be to, kuo daugiau laiko sugaištama duomenims surinkti, tuo didesnè tikimybè, kad kiti rinkos dalyviai jau bus juos ịvertinę ir prièmę investicinius sprendimus. Siekiant minimizuoti investuotojo laiko sąnaudas sprendimų paramos sistema turètų užtikrinti operatyvų automatini duomenų surinkimą iš patikimų informacijos šaltinių. Tai gali būti užtikrinta:

- $\quad$ sukuriant ir palaikant nuosavą investiciniam patrauklumui vertinti reikalingų duomenų bazę; 
- $\quad$ sprendimų paramos sistemą kuriant imonei, kuri jau turi reikiamą duomenų bazę;

- numatant sąveiką su jau esamomis, sprendimų paramos sistemomis, nepriklausančiomis sprendimų paramos sistemos kūrèjui.

Atsižvelgiant $i$ tai, jog skirtingi investuotojai gali pasirinkti skirtingus akcijų investicinio patrauklumo vertinimo kriterijus ir siekiant aprūpinti sistemą pakankamais duomenimis, tikslinga derinti minètus sistemos aprūpinimo duomenimis būdus numatant nuosavų informacinių išteklių derinimą su rinkoje prieinamais informacijos ištekliais:

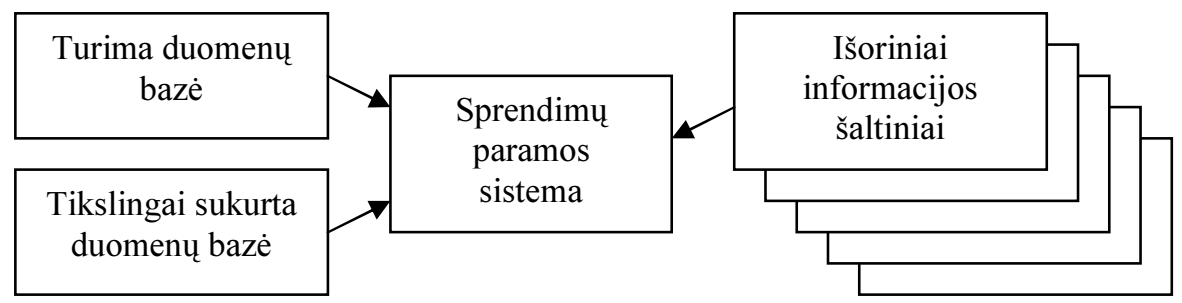

3.5 pav. Sprendimų paramos sistemos duomenų šaltiniai

Fig. 3.5. Data sources for decision support system Šaltinis: sudaryta autoriaus

3.5 paveiksle parodyta sistemos aprūpinimo duomenimis schema, kai sistema kuriama jau esant dalies investiciniam patrauklumui vertinti reikalingu duomenų bazei (pvz., susistemintai informacijai apie imonių finansinę atskaitomybę), tikslingai surenkant papildomus duomenis (pvz., esminiu naujienu apie imonių veikla, preliminarius rezultatus, prognozes sisteminimas sukuriant prielaidas naudoti juos analizei), kurių negalima susistemintų gauti iš kitu šaltinių, ir dali duomenų surenkant iš kitu informacijos šaltinių (pvz., prekybos akcijomis duomenis iš akciju biržos). Kitu informacijos šaltiniu ir duomenų bazių duomenimis taip pat gali būti naudojamasi siekiant i analizę itraukti tokius kokybinius kriterijus, kaip kokybès vadybos, aplinkosaugos ir pan. sertifikatų turejimas.

\subsubsection{Duomenų apdorojimo galimybès}

Siekiant užtikrinti maksimalią akcijų investicinio patrauklumo rodiklio atitiktị investuotojo poreikiams sprendimų paramos sistema turi turèti plačias duomenų analizès galimybes, apimančias:

- $\quad$ kriteriju pasirinkima;

- $\quad$ kriterijų svorių nustatymą; 
- MCDM metodo pasirinkima;

- investicinio patrauklumo vertinimo proceso struktūrizavimą.

Kriterijų pasirinkimas. Investuotojai gali laisvai pasirinkti kriterijus atsižvelgdami i prieinamų duomenų kieki - gali tiesiogiai itraukti bet kokius duomenis iš duomenų bazès arba vertinti akcijų investicini patrauklumą pasitelkdami išvestinius rodiklius, gautus apdorojant esamus duomenis. Sistemoje turi būti galimybè rankiniu būdu ịvesti kriterijus ir jų reikšmes, kurių negalima gauti iš sistemos turimų duomenų (pvz., investuotojo polinkis, jo subjektyvus požiūris i i̇monę, jos plètros perspektyvas, veiklos etiką, socialinę politiką ir pan.), turi būti numatyta kokybinių rodiklių kiekybinio įvertinimo ir itraukimo į daugiakriterị vertinimą galimybè.

Kriterijų svorių nustatymas. Sistema siūlo skirtingus kriterijų svorių nustatymo būdus, investuotojas turi galimybę koreguoti sistemos pasiūlytus svorius arba îvesti savo pasirinktus.

MCDM metodo pasirinkimas. Sistema užprogramuota darbui bent su keliais MCDM metodais ir leidžia pasirinkti, kuri MCDM metodą taikyti akcijų investiciniam patrauklumui nustatyti. Pateikiamas detalus kiekvieno iš siūlomu metodų aprašymas.

Investicinio patrauklumo vertinimo proceso struktūrizavimas. Investuotojas gali vykdyti kelių pakopų akcijų investicinio patrauklumo vertinimą. Kadangi investicinio patrauklumo vertinimas naudojant MCDM metodus reikalauja taikyti tuos pačius kriterijus visoms akcijoms analizuoti - tai trukdo užtikrinti skirtingų sektorių imonių akcijų palyginimo korektiškumą. Šio skyriaus pradžioje atliekant mokslininkų siūlomų akcijų investicinio patrauklumo vertinimo kriterijų analizę, buvo atkreiptas dėmesys, kad kai kurių sektorių (finansų ir ne finansų) imonių rodiklių palyginimo tarpusavyje galimybès yra ribotos dèl jų finansinès atskaitomybės ypatybių. Tačiau lyginant svarbus ne tik duomenu pakankamumas, bet ir lyginimo korektiškumas. Skirtingas i̇monių veiklos pobūdis gali nulemti, jog vienam sektoriui konkretaus rodiklio reikšmé gali būti labai gera, o kitam sektoriui ta pati reikšmé bus laikytina prasta, pavyzdžiui - grynojo pelningumo rodiklio priimtinumas prekybos sektoriuje ir aukštujų technologijų, biotechnologijų, farmacijos sektoriuose gali labai skirtis. Išvengti lyginimo nekorektiškumo gali padeti tik kriterijų reikšmių lyginimas atskiruose sektoriuose ir investicijoms patraukliausių akcijų atrinkimas sektoriaus lygiu. Kadangi, kaip jau buvo minèta pirmajame skyriuje, vienas iš pagrindiniu akcijų portfelio diversifikavimo būdų (ypač investuojant vienoje rinkoje) yra diversifikavimas pagal sektorius, investuotojai, siekdami sumažinti investicijų rizika, bus linkę rinktis skirtingų sektorių imones. Tai iškelia naują - skirtingose sektoriuose veikiančių imonių investicinio patrauklumo lyginimo - problemą. Šiai problemai spręsti siūlomas triju etapu vertinimas, kai pirmajame vertinimo etape yra vertinamas atskiru 
sektorių investicinis patrauklumas $\left(\mathrm{Q}_{\mathrm{S}}\right)$ ir priimamas sprendimas dèl sektorių atrankos, antrajame etape vertinamas kiekvieno atrinkto sektoriaus imoniu patrauklumas sektoriaus lygmeniu $\left(\mathrm{Q}_{\mathrm{A}}\right)$, trečiajame - nustatomas akcijos patrauklumas visos rinkos mastu $(\mathrm{Q})$, kur:

$$
Q=f\left(Q_{S} ; Q_{A}\right) .
$$

Struktūrizavimas neturi apsiriboti vien sektorių analizès galimybe, turi būti sąlygos grupuoti įmones pagal kitus parametrus (pvz., imonès dydis; šalis (jei vienoje biržoje prekiaujama kelių šalių akcijomis) ir pan.).

\subsubsection{Sprendimų prièmimas ir monitoringas}

Sistemoje numatytas sprendimu prièmimo galimybes galima santykiškai suskirstyti $\mathfrak{i}$ dvi dalis - periodinès analizès (pvz., pasirodžius ketvirtinėms ataskaitoms) sprendimu prièmimas ir sprendimų priemimas reaguojant i pasikeitusią situaciją rinkoje (rinkos naujienas, akcijų kainų pokyčius ir pan.).

Periodinès analizès sprendimų prièmimas yra tiesiogiai susijęs su portfelio optimizavimo procesu. Pasiūlytas bazinis akcijų investiciniu patrauklumu paremtas investiciju portfelio sudarymo modelis numato sprendimo priemimą dèl investuojamo kapitalo paskirstymo analizuojamoms akcijoms (optimalios portfelio sudèties), tačiau kaip parodè 2008-04 - 2009-04 laikotarpio rezultatai, per pati finansų krizès piką portfeliams nepavyko išvengti nuostolio, tai reiškia, kad sistema turi ne tik pasiūlyti geriausią investiciją iš analizuotų sąrašo, bet ir ivertinti, ar tam tikru laikotarpiu verta investuoti.

Sprendimui dèl investavimo konkrečiu laikotarpiu priimti sistemoje turi būti numatyta galimybe itraukti i analizę virtualią (lyginamaja) akciją itraukimo i analizę galimybè. Virtuali akcija, kurios kriterijų reikšmes galès nustatyti investuotojas (pvz., atsižvelgdamas i praeities laikotarpių tų pačių kriterijų sektoriaus vidurki, minimalią reikalaujamą investicijų grąžą ir pan.), naudojama kaip palyginamoji bazė skaičiuojant investicini akcijų patrauklumą. Iš visų analizuotų akcijų i portfelio sudèti galètų būti itraukiamos tik tenkinančios sąlygą:

$$
Q_{A} \geq Q_{V},
$$

čia $\mathrm{Q}_{\mathrm{A}}$ - analizuojamos realios akcijos investicinis patrauklumas; $\mathrm{Q}_{\mathrm{V}}$ - virtualios akcijos investicinis patrauklumas.

Sprendimu priemimas reaguojant į rinkos pokyčius yra operatyvaus portfelio valdymo elementas susijęs su nuolatiniu portfelio ir atskirų akcijų rezultatų monitoringu ir pirminio investavimo sprendimo keitimu. Sistemos monitoringo ir informacijos pateikimo posistemè turi užtikrinti operatyvų sistemos vartotojo informavimą apie investiciniam sprendimui priimti aktualius įvykius, o sistemos 
sprendimų prièmimo galimybès turi užtikrinti dviejų rūšių reakciją i pasikeitusią aplinką - tiesiogiai dalyvaujant investuotojui arba užprogramuotą. Pirmuoju atveju sistema tik informuoja investuotoją apie pasikeitimus, kurie gali turèti itakos investavimo sprendimo prièmimui, o investuotojas savarankiškai sprendžia dèl portfelio sudèties keitimo. Užprogramuotas sprendimų prièmimas investuotojui leidžia nusistatyti pagrindines sąlygas, kurioms pasikeitus, sistema automatiškai priimtų sprendimą keisti portfelio sudèti, pvz., nustatyti ribas, iki kiek pakilus arba kiek sumažejjus konkrečios akcijos kainai ji būtų automatiškai parduota, taip pat numatyti, kaip bus investuojamos lèšos pardavus dali akcijų (pvz., paskirstomos proporcingai kitoms akcijoms, investuojamos i patraukliausias akcijas ir pan.).

Monitoringas ir vartotojo informavimas yra esminès sistemos funkcijos, leidžiančios jos vartotojui koreguoti priimtus sprendimus ir sistemos nustatymus. Galima išskirti dvi pagrindines monitoringo kryptis, leisiančias užtikrinti gerus investavimo rezultatus:

- $\quad$ investavimo rezultatų ir rinkos pokyčių monitoringas;

- $\quad$ sistemos funkcionavimo efektyvumo monitoringas.

Efektyvus investavimo rezultatų ir rinkos pokyčių monitoringas ir sistemos vartotojo informavimas leis užtikrinti operatyvią reakciją i naujienas, pokyčius, naujausius įmonių veiklos rezultatus, ižvelgti naujas portfelio gražos padidinimo galimybes, pavojus ir rizikos šaltinius. Sistema pateikia informaciją apie portfelio vertès pokyčius, atskirų akcijų rezultatus, atkreipia dèmesị i labiausiai nuo tikètinų rezultatų nukrypstančias investicijas.

Sistemos funkcionavimo efektyvumo monitoringas parodo vartotojo pasirinktu sistemos nustatymų efektyvuma. Efektyvumui vertinti gali būti naudojamas pasirinktų kriterijų ar jų poveikio krypčių efektyvumo vertinimas (atitiktis investavimo rezultatams) arba virtualių (kita investiciju strategija besinaudojančių, kitus kriterijus ar MCDM metodus taikančiu)) portfelių sudarymas, jų rezultatų vertinimas ir lyginimas su pasirinktu portfeliu.

\subsubsection{Principinè sprendimų paramos sistemos veikimo schema}

3.4.1-3.4.3 poskyriuose buvo suformuluoti pagrindiniai reikalavimai akcijų investiciniu patrauklumu paremtai sprendimu paramos sistemai, tačiau siekiant geriau suvokti siūlomos sistemos esmę tikslinga parodyti joje vyksiančius procesus, jų nuoseklumą bei jų itakojimo galimybes priklausomai nuo konkretaus investuotojo poreikių. Tai parodo 3.6 paveiksle pateikta sprendimu paramos sistemos principinè veikimo schema. 


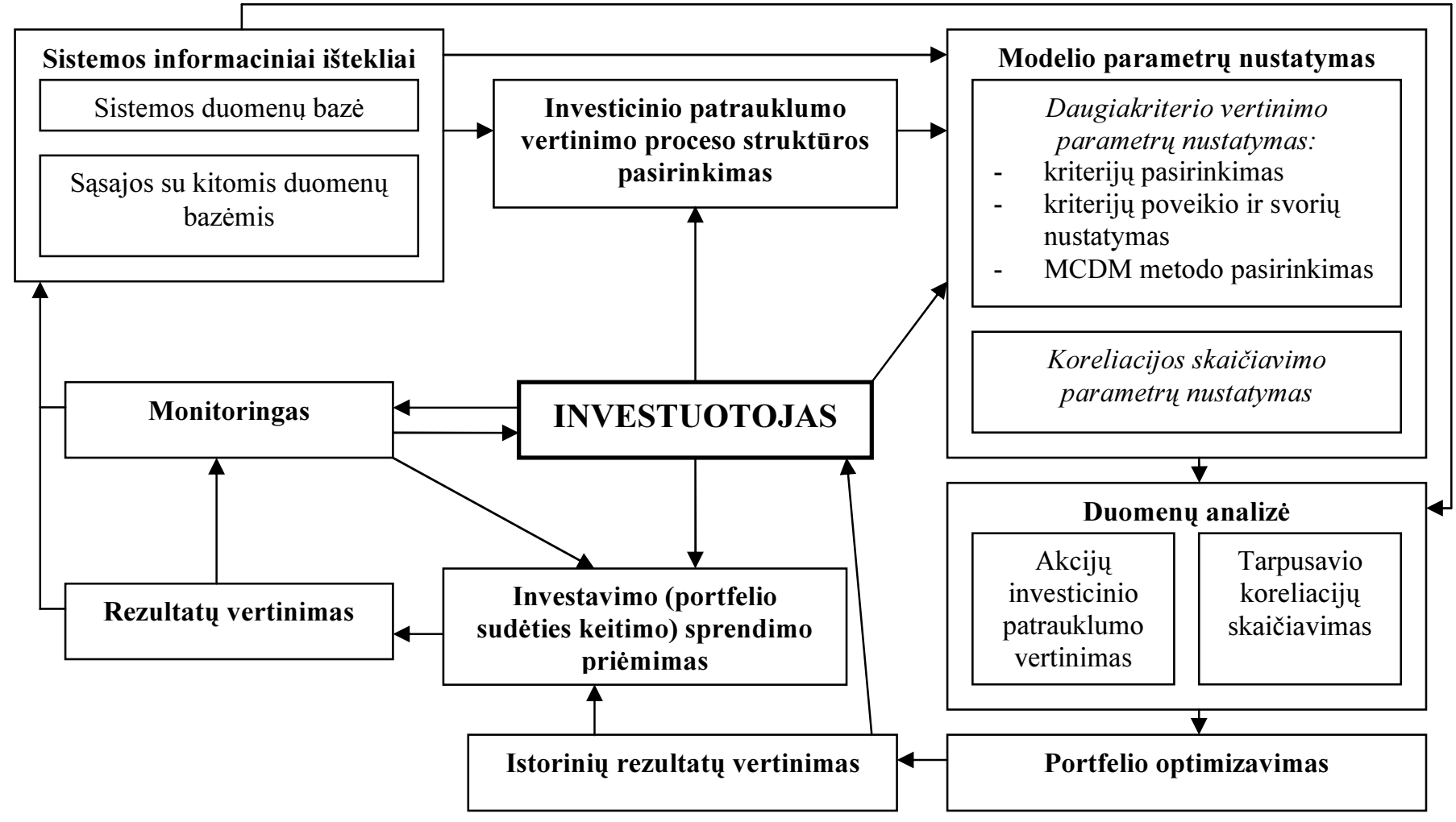

3.6 pav. Sprendimų paramos sistemos principinè veikimo schema

Fig. 3.6. The basic scheme of decision support system

Śaltinis: sudaryta autoriaus 
Sprendimų paramos sistemos naudotojas yra investuotojas, kuris, ivvertinęs sistemos informacinių išteklių pakankamumą bei sistemoje numatytas jų apdorojimo galimybes, priima sprendimą dèl investicinio patrauklumo vertinimo proceso struktūros pasirinkimo (ar visoms analizuotoms akcijoms bus taikomi tie patys kriterijai, ar akcijos bus grupuojamos ir ju investicinis patrauklumas bus vertinamas keliais etapais). Kadangi struktūros pasirinkimą didele dalimi nulemia akcijų ívairovè, šiame etape taip pat priimamas sprendimas dèl akcijų atrinkimo tolesnei analizei. Ivertinęs duomenų pakankamumą investuotojas nustato pagrindinius akcijų investiciniu patrauklumu paremto portfelio sudarymo modelio parametrus. Priklausomai nuo pasirinktos struktūros gali būti sudaroma viena arba kelios skirtingos daugiakriterio vertinimo parametrų aibès. Nustatomi akciju grąžos tarpusavio koreliacijos skaičiavimo parametrai (laikotarpis, už kuri skaičiuojama, ir duomenu periodiškumas). Remiantis nustatytais parametrais sistema, besinaudodama sistemos informaciniais ištekliais, apdoroja duomenis ir pasiūlo optimalią portfelio sudèti. Siekiant ivertinti modelio efektyvuma, jis yra testuojamas su istoriniais duomenimis. Testavimas su istoriniais duomenimis taip pat leidžia investuotojui pasirinkti geriausią iš kelių alternatyvių modelių. Remdamasis testavimo rezultatais investuotojas priima sprendimą: a) jei rezultatai netenkina lūkesčių - koreguoti modelio parametrus; b) jei istoriniai rezultatai yra priimtini investuotojui - investuoti i sistemos pasiūlytą akcijų portfeli. Prièmus sprendimą dèl investavimo sistema nuolat vertina investavimo rezultatus ir pateikia informaciją monitoringo posistemiui, kuris priklausomai nuo investuotojo jam numatytų nustatymų arba pateikia aktualią informaciją investuotojui, arba, esant užprogramuotiems veiksmams, priima sprendimą keisti portfelio sudèti. Portfelio rezultatų i̇vertinimo ir monitoringo informacija yra papildomi sistemos informaciniai ištekliai, kuriuose, sistemai pradejjus funkcionuoti, galètų taip pat būti parodoma informacija apie sèkmingiausiai „ex ante" veikiančių modelių rezultatus.

\subsection{Trečiojo skyriaus išvados}

Atlikta daugiakriterio sprendimų prièmimo metodų taikymo portfeliui optimizuoti galimybių analize, pasiūlytas ir testuotas akcijų investiciniu patrauklumu paremtas portfelio optimizavimo modelis ir numatytos jo plètros galimybès leidžia pateikti šias išvadas ir apibendrinimus:

1. Atlikta literatūros analizè parodè, $\mathrm{kad}$ yra dvi pagrindinès daugiakriterio sprendimų prièmimo metodų grupès, kurios gali būti taikomos optimizuojant portfelị: MADM metodai, kurie taikomi akcijų investiciniam patrauklumui nustatyti (akcijoms reitinguoti), ir MODM metodai, kurie gali būti naudojami tiesiogiai portfelio optimizavimo problemai spręsti. 
2. Apibendrinant kitų mokslininkų darbų analizę buvo pasiūlyta akcijų investicinio patrauklumo vertinimo kriterijų klasifikacija visus kriterijus suskirstant i keturias pagrindines grupes: fundamentaliosios analizės; akciju prekybos ir techninès analizės; mišrius; subjektyvius ir ekspertų vertinimus.

3. Mokslinejje literatūroje siūloma taikyti MODM metodus turinčius net iki 12 tikslų tačiau ivvertinus portfelio optimizavimo ir sprendimų prièmimo sudètingumą disertacijoje siūloma naudoti ne daugiau kaip 3 (geriau 2) tikslų sistemas, o i kitas investuotojui aktualias charakteristikas atsižvelgti vertinant investicinių objektų (akcijų) investicinị patrauklumą.

4. Pasiūlytas modelis i akcijų investicinio patrauklumo vertinimą leidžia itraukti pelningumo, rizikos ir likvidumo, fundamentaliuosius, akcijų kainos kitimo rinkoje, akcijų kainos pagristumo rodiklius ir subjektyvius vertinimus, taip pat siekti sumažinti bendros portfelio rinkos vertès svyravimus minimizuojant vidinę portfelio koreliaciją.

5. Detalizavus konkrečius pasiūlyto modelio igyvendinimo sprendimus buvo atliktas modelio testavimas (empirinis tyrimas), kurio rezultatai parodè, kad taikant modelį galima pasiekti didesnę investicijų grąžą nei investuojant turimas lèšas lygiomis dalimis ar i Markowitz efektyvuji portfelį: mažesnès rizikos portfelio grą̌a buvo vidutiniškai 3,64 proc. didesnè už Markowitz portfelio grąžą ir 1,22 proc. didesnè už faktiškai gerokai rizikingesnị bazinị portfeli. Investavus 1 litą 2006-04-01 investicijų vertè 2012-04-01 būtų atitinkamai: $\mathrm{P}($ bazinis $)$ - 1,72; $\mathrm{P}($ Markowitz $)$ - 1,56; $\mathrm{P}(80 / 20)$ - 1,92; $\mathrm{P}(60 / 40)$ 1,90. Pasiūlytas modelis leido gauti geresni portfelio rizikos ir grą̌zos santyki.

6. Pasiūlytas modelis leidžia adekvačiau ịvertinti investicijų grązos perspektyvas, parinkti geriau investuotoju poreikius atitinkanti portfeli, tačiau taip pat turi apribojimų - reikalauja daug vienarūšių duomenų, $\mathfrak{i}$ analizę negalima itraukti imonių, kurių finansiniai metai baigiasi skirtingais laikotarpiais. Šiuos apribojimus galètų panaikinti ir modelio taikymo galimybes smarkiai išplèsti sprendimų paramos sistemos sukūrimas, todèl šiame skyriuje buvo pateiktos akcijų investiciniu patrauklumu paremto portfelio sudarymo sprendimų paramos sistemos sukūrimo gairès (pagrindiniai reikalavimai sistemai ir jos veikimo principinè schema).

7. Investicinio patrauklumo požiūrio sudarant investicijų portfeli plètra užtikrintų ne tik investuotojo kaip asmenybès vystymąsi vis didesni svorị skiriant subjektyviems vertinimams ir polinkiams, bet ir prisidètų prie verslo ir šalies darnios plètros dèl efektyvesnio investuojamų lèšų paskirstymo perspektyviausioms veiklos sritims. 


\section{Bendrosios išvados}

Disertacijoje detalizavus investicijų portfelio sprendimus skirtingiems investuotojams - plačiai diversifikuoto portfelio sudarymo sprendimus portfelio sudèties nelinkusiems keisti investuotojams, aktyvaus portfelio valdymo sprendimus investuotojams, linkusiems užsidirbti iš trumpalaikių kainų svyravimų rinkoje, ir pasiūlius akcijų investiciniu patrauklumu paremtą portfelio sudarymo būdą periodiškai portfelio sudètị peržiūrintiems investuotojams, galima pateikti šias išvadas.

1. Didejanti investicinių priemoniu ịvairovè atveria naujas investavimo galimybes, leidžiančias gauti pelno ne tik iš tradicinių investavimo priemonių, bet ir iš valiutų kursų ar prekių ir išteklių kainų kitimo, o mažos ar net neigiamos gražzos tarpusavio koreliacijos užtikrina gerą portfelio diversifikaciją ir leidžia teigti, jog sisteminè vienos (pvz., akcijų) rinkos rizika gali būti sumažinta investuojant keliose skirtingose investicijų rinkose.

2. Plačiai diversifikuoto portfelio sudarymas parodè, jog Markowitz optimalaus portfelio laukiama grąža yra beveik trigubai didesnè nei analogiškos rizikos lyginamojo portfelio. Tai pagrindžia didesnę portfelio optimizavimo naudą esant didesniam aktyvų skaičiui ir mažesnèms koreliacijoms, o didesnès rizikos portfelių pasirinkimas gali būti neefektyvus dèl mažo ì portfelio sudètị itraukiamų aktyvų skaičiaus. 
3. Plačiai diversifikuoto portfelio efektyvumo testavimas parodè, kad 9 mėnesių laikotarpiu visų, išskyrus mažiausios rizikos, optimizuotų portfelių rezultatai viršijo jų laukiamą pelninguma, tačiau 14 mėnesių laikotarpiu buvo prastesni už laukiamus, t. y. dèl laikui bègant kintančių investicinių objektų charakteristikų didejant laikotarpiui nuo portfelio sudarymo momento, jo atitiktis investuotojo poreikiams gali mažèti, taigi net plačiai diversifikuojant portfeli tikslinga periodiškai peržiūrèti jo sudèti.

4. Mokslinejje literatūroje yra ịvertintos investicijų portfelio sudarymo naudojant nerizikingą skolinimą ir skolinimąsi galimybès, tačiau dèl realios rinkos apribojimų ir sąnaudų, siekiant aktyviai valdyti investicijų portfeli taikant finansini svertą efektyvioji riba igyja sudètingesnę forma, o finansinio sverto taikymas yra naudingas tik tuomet, kai yra intensyviai naudojamasi nerizikingo skolinimo ar skolinimosi galimybemis. Finansinio sverto taikymo tikslingumo aktyviai valdant portfeli empirinis tyrimas parodè, kad Lietuvos akcijų rinkos svyravimai yra pakankami, kad aktyviai valdant investicijų portfeli taikant finansini svertą būtų pasiektos geresnès pelningumo - rizikos kombinacijos, nei investuojant tik nuosavas lèšas.

5. Kritinis veiksnys siekiant efektyviai aktyviai valdyti investicijų portfeli yra tikslios akcijų grąžos prognozès. Kadangi atskiri prognozavimo metodai gali neužtikrinti prognozavimo tikslumo atskirais laikotarpiais, darbe pasiūlytas prognozavimo tikslumu paremtas prognozių integravimo metodas. Jo testavimo integruojant skirtingų periodų laiko eilučiu prognozes rezultatai parodè, jog paprastojo slankiojo vidurkio atveju integruotų prognozių vidutinès absoliučios prognozavimo paklaidos buvo mažesnès už 1 periodo neintegruotų prognozių paklaidas, prognozuojant indeksų pokyčius - 10,88 proc., akcijų grąža - 9,19 proc., valiutų kursų pokyčius $-9,98$ proc.; svertinio slenkančiojo vidurkio atveju atitinkamai: 14,45 proc., 12,01 proc., 12,87 proc.

6. Aktyviai valdant portfelị reikia dažnai keisti portfelio sudètį, tad svarbu užtikrinti tinkamą sprendimų keisti portfelio sudèti prièmimą. Mokslinèje literatūroje dažniausiai taikomas sandorių sąnaudų eliminavimu paremtas sprendimo keisti portfelio sudèti prièmimo metodas nèra tikslus, todèl priimant sprendimą keisti portfelio sudètị turètų būti įvertinamas laukiamo pelningumo pokyčio ir realiai patiriamų sąnaudų santykis.

7. Atlikus mokslinès literatūros daugiakriterio sprendimų prièmimo tematika analizę buvo pasiūlytas akcijų investiciniu patrauklumu paremtas portfelio sudarymo modelis, integruojantis MADM ir MODM metodu grupes portfelio pasirinkimo problemai spręsti. Detalizavus modelio igyvendinimo sprendimus modelis buvo testuojamas. Gauti rezultatai parode, kad taikant modeli galima pasiekti didesnę investicijų grąžą nei investuojant turimas léšas lygiomis dalimis ar i Markowitz efektyvuji portfelį: mažesnès rizikos portfelio 
grąža buvo vidutiniškai 3,64 proc. didesnè už Markowitz portfelio grąžą ir 1,22 proc. didesnè už faktiškai gerokai rizikingesni bazini portfelį.

8. Akcijų investiciniu patrauklumu paremtas portfelio sudarymas leidžia sudaryti geriau investuotojo poreikius atitinkantị portfeli, užtikrinti investuotojo kaip asmenybès vystymąsi, prisidèti prie verslo ir ekonomikos darnios plètros užtikrinimo, tačiau turi apribojimų, reikalauja daug duomenų ir laiko sąnaudų jiems apdoroti, todèl modelio taikymo galimybes ir pritaikomuma praktikoje galètu smarkiai išplèsti akcijų investiciniu patrauklumu paremto portfelio sudarymo sprendimų paramos sistema, kurios sukūrimo gairès yra suformuluotos disertacijoje. 



\section{Literatūra ir šaltiniai}

Afolabi, M. O.; Olude, O. 2007. Predicting Stock Prices Using a Hybrid Kohonen Self Organizing Map (SOM), in Proceedings of the 40th Hawaii International Conference on System Sciences.

Agapova, A. 2011. Conventional mutual index funds versus exchange-traded funds, Journal of Financial Markets 14: 323-343. doi: 10.1016/j.finmar.2010.10.005.

Anagnostopoulos, K.P.; Mamanis, G. 2010. A Portfolio Optimization Model with Three Objectives and Discrete variables, Computers \& Operations Research 37: 1285-1297. doi: 10.1016/j.cor.2009.09.009.

Antoniadis, A.; Paparoditis, E.; Sapatinas, T. 2006. A Functional Wavelet-Kernel Approach for Time Series Prediction, Journal of the Royal Statistical Society: Series B 68 (5): 837-857.

Araujo, R. A. 2010. A Quantum-inspired Evolutionary Hybrid Intelligent Approach for Stock Market Prediction, International Journal of Intelligent Computing and Cybernetics 3(1): 24-54. doi: 10.1108/17563781011028532

Arouri, M. E. H.; Jouini, J.; Nguyen, D. K. 2011. Volatility spillovers between oil prices and stock sector returns: Implications for portfolio management, Journal of International Money and Finance 30: 1387-1405. doi: 10.1016/j.jimonfin.2011.07.008.

Arouri, M. E. H.; Nguyen, D. K. 2010. Oil prices, stock markets and portfolio investment: Evidence from sector analysis in Europe over the last decade, Energy Policy 38: 4528-4539. doi: 10.1016/j.enpol.2010.04.007. 
Baixauli-Soler, J. S.; Alfaro-Cid, E.; Fernandez-Blanco, M. O. 2011. Mean-VaR Portfolio Selection Under Real Constraints, Computational Economics 37: 113-131. doi: 10.1007/s10614-009-9195-1.

Ballestero, E., et al. 2012. Socially Responsible Investment: A multicriteria approach to portfolio selection combining ethical and financial objectives, European Journal of Operational Research 216: 487-494. doi: 10.1016/j.ejor.2011.07.011.

Bange, M. M.; Khang, K.; Miller, T. W. 2008. Benchmarking the performance of recommended allocations to equities, bonds, and cash by international investment houses, Journal of Empirical Finance 15: 363-386. doi:10.1016/j.jempfin.2007.07.005.

Bange, M. M.; Miller, T. W. 2004. Return momentum and global portfolio allocations, Journal of Empirical Finance 11: 429-459. doi: 10.1016/j.jempfin.2004.02.002.

Bartram, S. M.; Brown, G. W.; Hund, J. E. 2007. Estimating systemic risk in the international financial system, Journal of Financial Economics 86: 835-869. doi:10.1016/j.jfineco.2006.10.001.

Batten, J. A.; Ciner, C.; Lucey, B. M. 2010. The macroeconomic determinants of volatility in precious metals markets, Resources Policy 35: 65-71. doi:10.1016/j.resourpol.2009.12.002.

Baur, D. G.; McDermott, T. K. 2010. Is gold a safe haven? International evidence, Journal of Banking \& Finance 34: 1886-1898. doi: 10.1016/j.jbankfin.2009.12.008.

Bernroider, E.; Stix, V. 2007. A Method Using Weight Restrictions in Data Envelopment Analysis for Ranking and Validity Issues in Decision Making, Computers \& Operations Research 34: 2637-2647. doi: 10.1016/j.cor.2005.10.005.

Beraldi, P.; Violi, A.; De Simone, F. 2011. A decision support system for strategic asset allocation, Decision Support Systems 51: 549-561. doi: 10.1016/j.dss.2011.02.017.

Berger, D.; Pukthuanthong, K.; Yang, J. J. 2011. International diversification with frontier markets, Journal of Financial Economics 101: 227-242. doi: 10.1016/j.jfineco.2011.02.009.

Berstein, W. J.; Wilkinson, D. 1997. Diversification, Rebalancing, and the Geometric Mean Frontier. <http://papers.ssrn.com>.

Bertsimas, D.; Pachamanova, D. 2008. Robust multiperiod portfolio management in the presence of transaction costs, Computers \& Operations Research 35: 3-17. doi: 10.1016/j.cor.2006.02.011.

Bhar, R.; Hammoudeh, S. 2011. Commodities and financial variables: Analyzing relationships in a changing regime environment, International Review of Economics and Finance 20: 469-484. doi: 10.1016/j.iref.2010.07.011.

Bhattacharyya, R.; Kar, S.; Majumder, D. D. 2011. Fuzzy Mean-Variance-Skewness Portfolio Selection Models by Interval Analysis, Computers and Mathematics with Applications 61: 126-137. doi: 10.1016/j.camwa.2010.10.039. 
Bikas, E.; Laurinavičius, A. 2009. Finansinių ir nekilnojamojo turto investicijų portfelio formavimo aspektai ir galimybès, Verslas: teorija ir praktika [Business: Theory and Practice] 10(2): 118-129. doi: 10.3846/1648-0627.2009.10.118-129.

Bilbao-Terol, A.; Arenas-Parra, M.; Canal-Fernandez, V. 2012. A fuzzy multi-objective approach for sustainable investments, Expert Systems with Applications 39(12): 1090410915. doi: 10.1016/j.eswa.2012.03.034.

Billio, M., et al. 2012. Econometric measures of connectedness and systemic risk in the finance and insurance sectors, Journal of Financial Economics 104 (3): 535-559. doi: 10.1016/j.jfineco.2011.12.010.

Blitz, D.; Huij, J. 2012. Evaluating the performance of global emerging markets equity exchange-traded funds, Emerging Markets Review 13: 149-158. doi: 10.1016/j.ememar.2012.01.004.

Byrne, P.; Lee, S. 2004. Different Risk Measures: Different Portfolio Compositions? Journal of Property Investment \&Finance 22(6): 501-511.

Cesari, R.; Cremonini, D. 2003. Benchmarking, portfolio insurance and technical analysis: a Monte Carlo comparison of dynamic strategies of asset allocation, Journal of Economic Dynamics \& Control 27: 987-1011. PII: S0165-1889(02)00052-0.

Charupat, N.; Miu, P. 2011. The pricing and performance of leveraged exchange-traded funds, Journal of Banking \& Finance 35: 966-977. doi:10.1016/j.jbankfin.2010.09.012

Chelley-Steeley, P.; Park, K. 2011. Intraday patterns in London listed Exchange Traded Funds, International Review of Financial Analysis 20: 244-251. doi: 10.1016/j.irfa.2011.05.001.

Cheung, C. S.; Miu, P. 2010. Diversification benefits of commodity futures, Journal of International Financial Markets, Institutions \& Money 20: 451-474. doi:10.1016/j.intfin.2010.06.003.

Chiou, W-J. P. 2009. Benefits of international diversification with investment constraints: An over-time perspective, Journal of Multinational Financial Management 19: 93-110. doi: 10.1016/j.mulfin.2008.08.001.

Chou, S. T., et al. 1997. A Stock Selection DSS Combining AI and Technical Analysis, Annals of Operations Research 75: 335-353.

Choudhry, T.; Lu, L.; Peng, K. 2007. Common stochastic trends among Far East stock prices: Effects of the Asian financial crisis, International Review of Financial Analysis 16: 242-261. doi: 10.1016/j.irfa.2006.12.001.

Christou, C.; Swamy, P. A. W. B.; Tawlas, G. S. 1998. A general framework for predicting returns from multiple currency investments, Journal of Economic Dynamics and Control 22: 977-1000. PII S0165-1889(97)00116-4.

Chun, G. H.; Sa-Aadu, J.; Shilling, J. D. 2004. The role of real estate in an institutional investor's portfolio revisited, Journal of Real Estate Finance and Economics 29(3): 295-320. 
Chung, H. Y.; Kim, J. B. 2001. A Structured Financial Statement Analysis and the Direct Prediction of Stock Prices in Korea, Asia-Pacific Financial Markets 8: 87-117.

Coeurdacier, N.; Guibaud S. 2011. International portfolio diversification is better than you think, Journal of International Money and Finance 30: 289-308. doi: 10.1016/j.jimonfin.2010.10.003.

Dai, M.; Yi, F. 2009. Finite-horizon optimal investment with transaction costs: A parabolic double obstacle problem, Journal of Differential Equations 246: 1445-1469. doi: 10.1016/j.jde.2008.11.003.

Das, M. C.; Sarkar, B.; Ray, S. 2012. A Framework to Measure Relative Performance of Indian Technical Institutions Using Antegrated Fuzzy AHP and COPRAS Methodology, Socio-Economic Planning Sciences 46(3): 230-241. doi: 10.1016/j.seps.2011.12.001.

Daskalaki, Ch.; Skiadopoulos, G. 2011. Should investors include commodities in their portfolios after all? New evidence, Journal of Banking \& Finance 35: 2606-2626. doi: 10.1016/j.jbankfin.2011.02.022.

Dierkes, M.; Erner, C.; Zeisberger, S. 2010. Investment horizon and the attractiveness of investment strategies: A behavioral approach, Journal of Banking \& Finance 341032 1046. doi: 10.1016/j.jbankfin.2009.11.003.

DiLellio, J. A.; Stanley, D. J. 2011. ETF trading strategies to enhance client wealth maximization, Financial services review 20: 145-163.

Driessen, J.; Laeven, L. 2007. International portfolio diversification benefits: Crosscountry evidence from a local perspective, Journal of Banking \& Finance 31: 16931712. doi: 10.1016/j.jbankfin.2006.11.006.

Delcourt, F. Petitjean M. 2011. To what extent is resampling useful in portfolio management? Applied Economics Letters 18: 239-244. doi: 10.1080/13504851003636123.

Dong, J., et al. 2004. A framework of Web-based Decision Support Systems for portfolio selection with OLAP and PVM, Decision Support Systems 37: 367- 376. doi: 10.1016/S0167-9236(03)00034-4.

Dutta, G., et al. 2006. Artificial Neural Network Models for Forecasting Stock Price Index in the Bombay Stock Exchange, Journal of Emerging Market Finance 5: 283-295. doi: $10.1177 / 097265270600500305$

Dzikevičius, A.; Šaranda, S. 2010. EMA Versus SMA Usage to Forecast Stock Markets: the Case of S\&P 500 and OMX Baltic Benchmark, Verslas: teorija ir praktika [Business: Theory and Practice] 11(3): 248-255. doi: 10.3846/btp.2010.27.

Eaker, M. R.; Grant, D. 2002. The wealth effects of portfolio rebalancing in emerging equity markets, Journal of Multinational Financial Management 12: 79-88. PII: S1042444X(01)00043-3.

Eakins, S. G.; Stansell, S. 2007. An examination of alternative portfolio rebalancing strategies applied to sector funds, Journal of Asset Management 8: 1-8. doi: 10.1057/palgrave.jam.2250055. 
Edwards, R.; Magee, J. 1992. Technical Analysis of Stock Trends. Sixth edition. New York: New York Institute of Finance. 624 p.

Ehling, P.; Ramos, S. B. 2006. Geographic versus industry diversification: Constraints matter, Journal of Empirical Finance 13: 396-416. doi: 10.1016/j.jempfin.2006.04.001.

Ehrgott, M.; Klamroth, K.; Schwehm, Ch. 2004. An MCDM Approach to Portfolio Optimization, European Journal of Operational Research 155: 752-770. doi: 10.1016/S0377-2217(02)00881-0.

Eiling, E., et al. 2012. International portfolio diversification: Currency, industry and country effects revisited, Journal of International Money and Finance 31(5): 12491278. doi: 10.1016/j.jimonfin.2012.01.015.

Elder, J.; Miao, H.; Ramchander, S. 2012. Impact of macroeconomic news on metal futures, Journal of Banking \& Finance 36: 51-65. doi: 10.1016/j.jbankfin.2011.06.007.

Erlwein, Ch.; Mitra, G.; Roman, D. 2012. HMM based scenario generation for an investment optimisation problem, Annals of Operation Research 193: 173-192. doi: 10.1007/s10479-011-0865-8.

Fang, Y.; Lai, K. K.; Wang, S-Y. 2006. Portfolio rebalancing model with transaction costs based on fuzzy decision theory, European Journal of Operational Research 175: 879-893. doi: 10.1016/j.ejor.2005.05.020.

Feng, Y., et al. 2011. Transaction fees and optimal rebalancing in the growth-optimal portfolio, Physica A 390: 1635-1645. doi: 10.1016/j.physa.2010.12.031.

Fernandez, V. 2008. Multi-Period Hedge Ratios for a Multi-Asset Portfolio when Accounting for Returns Co-Movement, The Journal of Futures Markets 28(2): 182-207. doi: 10.1002/fut.20294.

Firth M.; Gift M. 1999. An International Comparison of Analysis' Earnings Forecast Accuracy, International Advances in Economic Research 5(1): 56-64. doi: 10.1007/BF02295031

Fu, Ch.; Lari-Lavassani, A.; Li, X. 2010. Dynamic mean-variance portfolio selection with borrowing constraint, European Journal of Operational Research 200: 312-319. doi: 10.1016/j.ejor.2009.01.005.

Fugazza, C.; Guidolin, M.; Nicodano, G. 2007. Investing for the Long-run in European Real Estate, Journal of Real Estate Finance and Economics 34: 35-80. doi 10.1007/s11146-007-9002-5.

Garcia, F.; Guijarro, F.; Moya, I. 2010. A Goal Programming Approach to Estimating Performance Weights for Ranking Firms, Computers \& Operations Research 37: 15971609. doi: 10.1016/j.cor.2009.11.018.

Geman, H.; Karoubi, C. 2008. WTI crude oil Futures in portfolio diversification: The time-to-maturity effect, Journal of Banking \& Finance 32: 2553-2559. doi: 10.1016/j.jbankfin.2008.04.002. 
Ghosh, S. 2011. Examining crude oil price - Exchange rate nexus for India during the period of extreme oil price volatility, Applied Energy 88 1886-1889. doi: 10.1016/j.apenergy.2010.10.043.

Gilli, N., Kellezi, E. 2000. A Heuristic Approach to Portfolio Optimization. Available from Internet: $<\mathrm{http}: / /$ www.bankingemba.com/rp20.pdf $>$.

Grammatikos, T.; Vermeulen, R. 2012. Transmission of the financial and sovereign debt crises to the EMU: Stock prices, CDS spreads and exchange rates, Journal of International Money and Finance 31: 517-533. doi:10.1016/j.jimonfin.2011.10.004.

Gupta, P.; Inuiguchi, M.; Mehlawat, M. K. 2011. A Hybrid Approach for Constructing Suitable and Optimal Portfolios, Expert Systems with Applications 38: 5620-5632. doi: 10.1016/j.eswa.2010.10.073.

Hai-xiang,Y.; Zhong-fei, J. 2009. Portfolio Selection with Different Borrowing-Lending Rates: Utility Maximization Model based on Mean and VaR, Systems Engineering Theory \& Practice 29(1): 22-29.

Hallerbach, W., et al. 2004. A framework for managing a portfolio of socially responsible investments, European Journal of Operational Research 153: 517-529. doi: 10.1016/S0377-2217(03)00172-3.

Hammoudeh, S.; Yuan, Y. 2008. Metal volatility in presence of oil and interest rate shocks, Energy Economics 30: 606-620. doi: 10.1016/j.eneco.2007.09.004.

Hammoudeh, D.; Malik, F.; McAleer, M. 2011. Risk management of precious metals, The Quarterly Review of Economics and Finance 51: 435-441. doi: 10.1016/j.qref.2011.07.002.

Hamza, O.; L'Her, J-F.; Roberge M. 2007. Active Currency Hedging Strategies for Global Equity Portfolios, The Journal of Investing 16(4): 146-166. doi: 10.3905/joi.2007.698985.

Harper, J. T.; Madura, J.; Schnusenberg, O. 2006. Performance comparison between exchange-traded funds and closed-end country funds, Journal of International Financial Markets, Institutions \& Money 16: 104-122. doi: 10.1016/j.intfin.2004.12.006.

Hassan, R.; Nath, B. 2005. Stock Market Forecasting Using Hidden Markov Model: A New Approach, in Proceedings of the 2005 5th International Conference on Intelligent Systems Design and Applications (ISDA'05).

Hassan, R.; Nath, B.; Kirley M. 2007. A Fusion Model of HMM, ANN and GA for Stock Market Forecasting, Expert Systems with Applications 33: 171-180. doi:10.1016/j.eswa.2006.04.007

Heaney, R.; Sriananthakumar S. 2012. Time-varying correlation between stock market returns and real estate returns, Journal of Empirical Finance 19(4): 583-594. doi: 10.1016/j.jempfin.2012.03.006.

Ho, R. Y.; Lee, R. S. 1995. Correlation Structure Forecasting \& Ex Ante Portfolio Selection Strategies in the Japan Market, Financial Engineering and the Japanese Markets 2: 1-14. 
Huang, Ch. F. 2012. A Hybrid Stock Selection Model Using Genetic Algorithms and Support Vector Regression, Applied Soft Computing 12: 807-818. doi: 10.1016/j.asoc.2011.10.009.

Huang, M-Y.; Lin, J-B. 2011. Do ETFs provide effective international diversification? Research in International Business and Finance 25: 335-344. doi: 10.1016/j.ribaf.2011.03.003.

Huang, X.; Zhou, H.; Zhu, H. 2009. A framework for assessing the systemic risk of major financial institutions, Journal of Banking \& Finance 33: 2036-2049. doi:10.1016/j.jbankfin.2009.05.017.

Huang, X.; Zhou, H.; Zhu, H. 2012. Assessing the systemic risk of a heterogeneous portfolio of banks during the recent financial crisis, Journal of Financial Stability 8(3): 193-205. doi:10.1016/j.jfs.2011.10.004.

Jana, P.; Roy, T. K.; Mazumder, S. K. 2009. Multi-objective possibilistic model for portfolio selection with transaction cost, Journal of Computational and Applied Mathematics 228: 188-196. doi: 10.1016/j.cam.2008.09.008.

Jandaghi, G., et al. 2010. Application of Fuzzy-neural Networks in Multi-ahead Forecast of Stock price, African Journal of Business Management 4(6): 903-914.

Jarret, J. E.; Schilling, J. 2008. Daily Variation and Predicting Stock Market Returns for the Frankfurter Börse (Stock Market), Journal of Business Economics and Management 9(3): 189-198. doi: 10.3846/1611-1699.2008.9.189-198.

Jarrow, R. A. 2010. Understanding the risk of leveraged ETFs, Finance Research Letters 7: 135-139. doi: 10.1016/j.frl.2010.04.001.

Jones, Ch. P. 1991. Investments Analysis and Management. New York: John Wiley \& Sons. 777 p.

Jones, S. K.; Stine, J. B. 2010. Expected utility and the non-normal returns of common portfolio rebalancing strategies, Journal of Asset Management 10: 406-419. doi: 10.1057/jam.2009.22.

Joy, M. 2011. Gold and the US dollar: Hedge or haven? Finance Research Letters 8: 120-131. doi:10.1016/j.frl.2011.01.001.

Jurevičienė, D.; Klimavičienė, A. 2008. Asmeninių finansų valdymo teoriniai aspektai gyvenimo ciklo požiūriu, Verslas: teorija ir praktika [Business: Theory and Practice] 9(1): 22-32. doi:10.3846/1648-0627.2008.9.22-32

Kenourgios, D.; Padhi, P. 2012. Emerging markets and financial crises: Regional, global or isolated shocks? Journal of Multinational Financial Management 22: 24-38. doi: 10.1016/j.mulfin.2012.01.002.

Kenourgios, D.; Samitas, A.; Paltalidis, N. 2011. Financial crises and stock market contagion in a multivariate time-varying asymmetric framework, Journal of International Financial Markets, Institutions \& Money 21: 92-106. doi: 10.1016/j.intfin.2010.08.005. 
Kim, B-H.; Kim, S. 2012. Transmission of the global financial crisis to Korea, In Journal of Policy Modeling. <http://www.sciencedirect.com>. doi: 10.1016/j.jpolmod.2012.01.005.

Kim, D. 2012. Is currency hedging necessary for emerging-market equity investment? Economics Letters 116: 67-71. doi: 10.1016/j.econlet.2012.01.008.

Kim, S-J.; Moshirian, F.; Wu, E. 2006. Evolution of international stock and bond market integration: Influence of the European Monetary Union, Journal of Banking \& Finance 30: 1507-1534. doi: 10.1016/j.jbankfin.2005.05.007.

Kissel, R.; Glantz, M.; Malamut, R. 2004. A practical framework for estimating transaction costs and developing optimal trading strategies to achieve best execution, Finance Research Letters 1: 35-46. doi: 10.1016/S1544-6123(03)00004-7.

Konno, H.; Shirakawa, H.; Yamazaki, H. 1993. A Mean-Absolute Deviation-Skewness Portfolio Optimization Model, Annals of Operation Research 45: 205-220.

Konno, H.; Suzuki, K. 1995. A Mean-Variance-Skewness Portfolio Optimization Model, Journal of the Operations Research Society of Japan 38(2): 173-187.

Kozat, S. S.; Singer, A. C. 2011. Universal Semiconstant Rebalanced Portfolios, Mathematical Finance 21(2): 293-311. doi: 10.1111/j.1467-9965.2010.00430.x

Kozhan, R.; Schmid, W. 2009. Asset allocation with distorted beliefs and transaction costs, European Journal of Operational Research 194: 236-249. doi: 10.1016/j.ejor.2007.12.002.

Krejic, N.; Kumaresan, M.; Roznjik, A. 2011. VaR optimal portfolio with transaction costs, Applied Mathematics and Computation 218: 4626-4637. doi: 10.1016/j.amc.2011.10.047.

Kroszner, R. S.; Laeven, L.; Klingebiel, D. 2007. Banking crises, financial dependence, and growth, Journal of Financial Economics 84: 187-228. doi: 10.1016/j.jfineco.2006.05.001.

Kuhn, D.; Leunberg, D. G. 2010. Analysis of the rebalancing frequency in log-optimal portfolio selection, Quantitative Finance 10(2): 221-234. doi: $10.1080 / 14697680802629400$.

Kumar, M. 2009. Nonlinear Prediction of the Standard \& Poor's 500 and the Hang Seng Index Under a Dynamic Increasing Sample, Asian Academy of Management Journal of Accounting and Finance 5(2): 101-118.

Kumar, M. 2010. Modelling Exchange Rate Returns Using Non-linear Models, The Journal of Applied Economic Research 4: 101-125. doi: 10.1177/097380100900400105.

Lagoarde-Segot, T.; Lucey B. M. 2007. International portfolio diversification: Is there a role for the Middle East and North Africa? Journal of Multinational Financial Management 17: 401-416. doi: 10.1016/j.mulfin.2007.01.001 
Lee, Ch-Ch.; Chien, M-S.; Lin, T. C. 2012. Dynamic modelling of real estate investment trusts and stock markets, Economic Modelling 29 (2012) 395-407. doi: 10.1016/j.econmod.2011.11.008.

Lee, S.; Stevenson, S. 2006. Real estate in the mixed-asset portfolio: the question of consistency, Journal of Property Investment \& Finance 24(2): 123-135. doi $10.1108 / 14635780610655085$.

Lee, W. S., et al. 2009. Combined MCDM Techniques for Exploring Stock Selection Based on Gordon Model, Expert Systems with Applications 36: 6421-6430. doi: 10.1016/j.eswa.2008.07.084.

Leigh, W.; Purvis, R.; Ragusa, J. M. 2002. Forecasting the NYSE Composite Index with Technical Analysis, Pattern Recognizer, Neural Network, and Genetic Algorithm: a Case Study in Romantic Decision Support, Decission support systems 32: 361-377.

Leung, A. P. 2011. Reactive investment strategies, Insurance: Mathematics and Economics 49: 89-99. doi:10.1016/j.insmatheco.2011.02.004.

Li, J.; Tsang, E. P. K. 1999. Improving Technical Analysis Predictions: An Application of Genetic Programming, in Proceedings of Florida Artificial Intelligence Research Symposium, USA.

Li, K.; Sarkar, A.; Wang, Z. 2003. Diversification benefits of emerging markets subject to portfolio constraints, Journal of Empirical Finance 10: 57-80. PII: S09275398(02)00027-0.

Li, X.; Qin, Z. Kar, S. 2010. Mean-Variance-Skewness Model for Portfolio Selection with Fuzzy Returns, European Journal of Operational Research 202: 239-247. doi:10.1016/j.ejor.2009.05.003.

Lin, T. C.; Lin, Z-H. 2011. Are stock and real estate markets integrated? An empirical study of six Asian economies, Pacific-Basin Finance Journal 19: 571-585. doi: 10.1016/j.pacfin.2011.05.001.

Liu, S.; Wang, S. Y.; Qiu W. 2003. Mean-Variance-Skewness Model for Portfolio Selection with Transaction Costs, International Journal of Systems Science 34(4): 255262. doi: $10.1080 / 0020772031000158492$.

Lo, A. W.; Petrov, C.; Wierzbicki, M. 2003. It‘s 11 PM - Do You Know Where Your Liquidity Is? The Mean-Variance-Liquidity Frontier, Journal of Investment Management 1(1): 55-93.

Lu, Ch., et al. 2011. Predicting Stock Index Using an Integrated Model of NLICA, SVR and PSO, in ISNN'11 Proceedings of the 8th International Conference on Advances in Neural Networks - Volume Part III.

Macijauskas, L. 2011. Biržoje prekiaujamu fondų (ETF) bendrojo išlaidų rodiklio tyrimas, Mokslas - Lietuvos ateitis 3(4): 28-34. doi: 10.3846/mla.2011.066.

Markowitz, H. 1959. Portfolio Selection: Efficient Diversification of Investment. John Wiley \& Sons. 344 p. 
Markowitz, H. M. 1952. Portfolio Selection, Journal of Finance 7(1): 77-91.

Markowitz, H. M. 1999. The early history of portfolio theory: 1600-1960, Financial Analysts Journal 55(4): 5-16.

Mehdi, K.; Mehdi, B. 2011. A Novel Hybridization of Artificial Neural Networks and ARIMA Models for Time Series Forecasting, Applied Soft Computing 11: 2664-2675. doi:10.1016/j.asoc.2010.10.015

Meric, I.; Ratner, M.; Meric, G. 2008. Co-movements of sector index returns in the world's major stock markets in bull and bear markets: Portfolio diversification implications, International Review of Financial Analysis 17: 156-177. doi: 10.1016/j.irfa.2005.12.001.

Middleton, C. A. J.; Fifield, S. G. M.; Power, D. M. 2008. An investigation of the benefits of portfolio investment in Central and Eastern European stock markets, Research in International Business and Finance 22: 162-174. doi: 10.1016/j.ribaf.2007.04.001.

Milosev, I., et al. 2011. Global Investments and Strategies of Recovery from the Recesion, Procedia Social and Behavioral Sciences 24: 147-158. Proceedings of 7th International Strategic Management Conference. doi: 10.1016/j.sbspro.2011.09.077.

Missiakoulis, S.; Vasiliou, D.; Eriotis, N. 2010. Arithmetic Mean: a Bellwether for Unbiased Forecasting of Portfolio Performance, Managerial Finance 36 (11): 958-968. doi: $10.1108 / 03074351011081277$

Morales, L.; Andreosso-O'Callaghan, B. 2011. Comparative analysis on the effects of the Asian and global financial crises on precious metal markets, Research in International Business and Finance 25: 203-227. doi:10.1016/j.ribaf.2011.01.004.

Nanda, S. R.; Mahanty, B.; Tiwari, M. K. 2010. Clustering Indian stock market data for portfolio management, Expert Systems with Applications 37: 8793-8798. doi: 10.1016/j.eswa.2010.06.026.

Narayan, P. K.; Liu, R. 2011. Are shocks to commodity prices persistent? Applied Energy 88: 409-416. doi: 10.1016/j.apenergy.2010.07.032.

Nazlioglu, S.; Soytas, U. 2011 a. Oil price, agricultural commodity prices, and the dollar: A panel cointegration and causality analysis, Energy Economics 34(4): 1098-1104. doi:10.1016/j.eneco.2011.09.008.

Nazlioglu, S.; Soytas, U. 2011b. World oil prices and agricultural commodity prices: Evidence from an emerging market, Energy Economics 33: 488-496. doi: 10.1016/j.eneco.2010.11.012.

Nenortaite, J. Simutis, R. 2006. Development and Evaluation of Decision-Making Model for Stock Markets, Journal of Global Optimization 36: 1-19. doi: 10.1007/s10898-0055371-6.

O‘Brien, J. 2006. Rebalancing: A Tool for Managing Portfolio Risk, Journal of Financial Service Professionals 60(3): 62-68. 
Olma, A. R.; Siegel, L. B. 2004. A New Framework for International Investing, The Journal of Portfolio Management 30: 55-69.

Olson, D.; Bley, J. 2008. Asset allocation with differential borrowing and lending rates, International Review of Economics and Finance 17: 629-643. doi:10.1016/j.iref.2007.05.007.

Painter, M. J. 2011. Is farmland as good as gold, Economics Research International: 2011: 1-8. doi: 10.1155/2011/924708.

Panda, Ch.; Narasimhan, V. 2006. Predicting Stock Returns : An Experiment of the Artificial Neural Network in Indian Stock Market, South Asia Economic Journal 7(2): 205-218. doi: 10.1177/139156140600700203.

Payne, J. E.; Sahu, A. P. 2004. Random walks, cointegration, and the transmission of shocks across global real estate and equity markets, Journal of Economics and Finance 28(2): 198-210.

Patro, D. K.; Qi, M.; Sun, X. 2012. A simple indicator of systemic risk, In Journal of Financial Stability. <http://www.sciencedirect.com>. doi: 10.1016/j.jfs.2012.03.002.

Phylaktis, K.; Ravazzolo F. 2005. Stock market linkages in emerging markets: implications for international portfolio diversification, Journal of International Financial Markets, Institutions \& Money 15: 91-106. doi: 10.1016/j.intfin.2004.03.001.

Pindoriya, N. M.; Singh, S. N.; Singh S. K. 2010. Multi-objective Mean-VarianceSkewness Model for Generation Portfolio Allocation in Electricity Markets, Electric Power Systems Research 80: 1314-1321. doi: 10.1016/j.epsr.2010.05.006.

Podvezko, V. 2011. The Comparative Analysis of MCDA Methods SAW and COPRAS, Inzinerine Ekonomika [Engineering Economics] 2: 134-146. doi: 10.5755/j01.ee.22.2.310.

Roman, D.; Darby-Dowman, K.; Mitra, G. 2007. Mean-Risk Models Using Two Risk Measures: a Multi-objective Approach, Quantitative Finance 7(4): 443-458. doi: 10.1080/14697680701448456.

Roon, F. A.; Nijman, T. E.; Werker, B. J. M. 2003. Currency hedging for international stock portfolios: The usefulness of mean-variance analysis, Journal of Banking \& Finance 27: 327-349. PII: S03 7 8-4 266 (0 1)0 025 1- 5.

Roy, A. D. 1952. Safety First and the Holding of Assets, Econometrica 20(3): 431-449.

Rutkauskas, A. V. 2005a. Portfelio sprendimai valiutų kursų ir kapitalo rinkose, Verslas: teorija ir praktika [Business: Theory and Practice] 6(2): 107-116.

Rutkauskas, A. V. 2005b. The double trump decision management model in global exchange, Ekonomika [Economics] 72: 84-104.

Rutkauskas, A. V. 2006. Adekvačiojo investavimo portfelio anatomija ir sprendimai panaudojant imitacines technologijas, Ekonomika [Economics] 75: 52-76. 
Rutkauskas, A. V.; Stasytytè, V. 2008. Stratification of Stock Profitabilities - the Framework for Investors' Possibilities Research in the Market, Intelektine ekonomika [Intellectual Economics] 1(3): 65-72.

Rutkauskas, A. V.; Stasytytė, V.; Borisova, J. 2009. Adequate Portfolio as a Conceptual Model of Investment Profitability, Risk and Reliability Adjustment to Investor's Interests, Economics \& Management 14: 1170-1174.

Sadjadi, S. J.; Seyedhosseini, S.M.; Hassanlou, Kh. 2011. Fuzzy multi period portfolio selection with different rates for borrowing and lending, Applied Soft Computing 11: 3821-3826. doi: 10.1016/j.asoc.2011.02.015.

Sallehuddin, R.; Shamsuddin, S. M. Hj. 2007. Forecasting Time Series Data Using Hybrid Grey Relational Artificial Neural Network and Auto Regressive Integrated Moving Average Model, Neural Network World 6: 573-605.

Samaras G. D.; Matsatsinis, N. F. 2003. A Multicriteria DSS for a Global Stock Evaluation, Operational Research. An International Journal 3(3): 281-306.

Samaras, G. D.; Matsatsinis, N. F.; Zopounidis, C. 2008. A multicriteria DSS for stock evaluation using fundamental analysis, European Journal of Operational Research 187: 1380-1401. doi: 10.1016/j.ejor.2006.09.020.

Samarakoon, L. P. 2011. Stock market interdependence, contagion, and the U.S. financial crisis: The case of emerging and frontier markets, Journal of International Financial Markets, Institutions \& Money 21: 724-742. doi: 10.1016/j.intfin.2011.05.001.

Sari, M.; Hammoudeh, S.; Soytas, U. 2010. Dynamics of oil price, precious metal prices, and exchange rate, Energy Economics 32: 351-362. doi: 10.1016/j.eneco.2009.08.010.

Seiler, M. J.; Webb, J. R.; Myer, F. C. N. 1999. Diversification Issues in Real Estate Investment, Journal of Real Estate Literature, 7: 163-179.

Sevastjanov, P.; Dymova, L. 2009. Stock Screening with Use of Multiple Criteria Decision Making and Optimization, Omega 37: 659-671. doi: 10.1016/j.omega.2008.04.002.

Shafiee, S.; Topal, E. 2010. An overview of global gold market and gold price forecasting, Resources Policy 35: 178-189. doi: 10.1016/j.resourpol.2010.05.004.

Sharpe, W. F. 1963. A simplified model for portfolio analysis, Management science 9(2): 277-293.

Sharpe, W. F. 1964. Capital asset prices: The theory of market equilibrium under conditions of risk, The Journal of Finance 19(3): 425-442.

Soleimani, H.; Golmakani, H. R.; Salimi, M. H. 2009. Markowitz-based portfolio selection with minimum transaction lots, cardinality constraints and regarding sector capitalization using genetic algorithm, Expert Systems with Applications 36: 5058-5063. doi: 10.1016/j.eswa.2008.06.007. 
Syriopoulos, T. 2011. Financial integration and portfolio investments to emerging Balkan equity markets, Journal of Multinational Financial Management 21: 40-54. doi: 10.1016/j.mulfin.2010.12.006.

Stankevičienè, J.; Žinytė, S. 2011. Valuation Model of New Start-up Companies: Lithuanian Case, Verslas: teorija ir praktika [Business: Theory and Practice] 12(4): 379-389. doi: 10.3846/btp.2011.39.

Stasytytè, V. 2008. From Two-Dimensional Profit-Risk to Three-Dimensional ProfitReliability-Risk in Capital Markets, 20th EURO Mini Conference „Continuous Optimization and Knowledge-Based Technologies " (EurOpt-2008), 149-153.

Stasytytè, V. 2011. Investiciju portfelio sprendimu paramos sistema. Daktaro disertacija. Vilnius: Technika. $147 \mathrm{p}$.

Stern, H. S. 1996. Neural Networks in Applied Statistics, Technometrics 38(3): 205-214.

Steur, R. E.; Na, P. 2003. Multiple criteria decision making combined with finance: A categorized bibliographic study, European Journal of Operational Research 150: 496515. doi: 10.1016/S0377-2217(02)00774-9.

Steuer, R.E.; Qi, Y.; Hirschberger, M. 2005. Multiple Objectives in Portfolio Selection, Journal of Financial Decision Making 1(1): 11-26.

Steuer, R.E.; Qi, Y.; Hirschberger, M. 2007. Suitable-Portfolio Investors, Nondominated Frontier Sensitivity, and the Effect of Multiple Objectives on Standard Portfolio Selection, Annals or Operations Research 152: 297-317. doi: 10.1007/s10479-0060137-1.

Stevenson S. 2007. A Comparison of the Forecasting Ability of ARIMA Models, Journal of Property Investment \& Finance 25(3): 223-240. doi: 10.1108/14635780710746902.

Suh, S. 2012. Measuring systemic risk: A factor-augmented correlated default approach, Journal of Financial intermediation 21: 341-358. doi:10.1016/j.jfi.2011.10.003.

Szego, G. 2005. Measures of Risk. European Journal of Operational Research 163: 519. doi: 10.1016/j.ejor.2003.12.016.

Tee, K-H. 2009. Is active currency management effective for international equity portfolios involving managed futures and hedge funds? Journal of Derivatives \& Hedge Funds 15: 137-148. doi: 10.1057/jdhf.2009.7.

Thapa, Ch.; Poshakwale S. S. 2012. Country-specific equity market characteristics and foreign equity portfolio allocation, Journal of International Money and Finance 31: 189-211. doi: 10.1016/j.jimonfin.2011.10.011.

Thapa, Ch.; Poshakwale S. S. 2010. International equity portfolio allocations and transaction costs, Journal of Banking \& Finance 34: 2627-2638. doi: 10.1016/j.jbankfin.2010.05.004. 
Thawornwong, S.; Enke, D. 2004. The Adaptive Selection of Financial and Economic Variables for Use with Artificial Neural Networks, Neurocomputing 56: 205-232. doi: 10.1016/j.neucom.2003.05.001

Tiryaki, F.; Ahlatcioglu, M. 2005. Fuzzy Stock Selection Using a New Fuzzy Ranking and Weighting Algorithm, Applied Mathematics and Computation 170: 144-157. doi: 10.1016/j.amc.2004.10.092.

Tupenaite, L. 2010. Multiple Criteria Assessment of the Built and Human Environment Renovation Projects: Doctoral dissertation. Vilnius Gediminas Technical University. Vilnius: Technika. $129 \mathrm{p}$.

Tvaronavičienè, M.; Michailova, J. 2004. Optimalaus akcijų portfelio sudarymas, naudojantis H. Markowitz „Portfelio teorija“, Verslas: teorija ir praktika [Business: Theory and Practice] 5(3): 135-143.

Uctum, M.; Uctum, R. 2011. Crises, portfolio flows, and foreign direct investment: An application to Turkey, Economic Systems 35: 462-480. doi: 10.1016/j.ecosys.2010.10.005.

Ustin, O.; Kasimbeyli, R. 2012. Combined Forecasts in Portfolio Optimization: A Generalized Approach, Computers \& Operations Research 39: 805-819. doi: 10.1016/j.cor.2010.09.008.

Vahidov, R.; He, X. 2009. Situated DSS for personal finance management: Design and evaluation, Information \& Management 46: 453-462. doi: 10.1016/j.im.2009.06.007.

Vahidov, R.; He, X. 2010. Situated DSS for personal finance management: Design and evaluation, Information \& Management 47: 78-86. doi: 10.1016/j.im.2009.11.001.

Vasiliauskaite, D. 2004. Optimalaus vertybiniu popieriu portfelio sudarymo ypatumai, Ekonomika [Economics] 67(2): 117-130.

Vivian, A.; Wohar, M. E. 2012. Commodity volatility breaks, Journal of International Financial Markets, Institutions \& Money 22: 395-422. doi:10.1016/j.intfin.2011.12.003.

Voulgaris, F.; Doumpos, M.; Zopounidis, C. 2000. On the Evaluation of Greek Industrial SMEs' Performance via Multicriteria Analysis of Financial Ratios, Small Business Economics 15: 127-136.

Walker E. 2008. Strategic currency hedging and global portfolio investments upside down, Journal of Business Research 61: 657-668. doi: 10.1016/j.jbusres.2007.06.041.

Willenbrock, S. 2011. Diversification Return, Portfolio Rebalancing, and the Commodity Return Puzzle, Financial analysts Journal 67(4): 42-49.

Yamori, N. 2011. Commodity ETFs in the Japanese stock exchanges, Journal of Advanced Studies in Finance 2(1(3)): 47-52.

Yao, J.; Tan, Ch. L.; Poh, H. 1999. Neural Networks for Technical Analysis: A Study on KLCI, International Journal of Theoretical and Applied Finance 2(2): 221-241. 
Xidonas, P., et al. 2011. IPSSIS: An Integrated Multicriteria Decision Support System for Equity Portfolio Construction and Selection, European Journal of Operational Research 210: 398-409. doi: 10.1016/j.ejor.2010.08.028.

Xidonas, P.; Askounis, D.; Psarras, J. 2009a. Common Stock Portfolio Selection: a Multiple Criteria Decision Making Methodology and an Application to the Athens Stock Exchange, Operational Research. An International Journal 9: 55-79. doi: 10.1007/s12351-008-0027-1.

Xidonas, P.; Mavrotas, G.; Psarras, J. 2009b. A Multicriteria Methodology for Equity Selection Using Financial Analysis, Computers \& Operations Research 36: 3187-3203. doi: 10.1016/j.cor.2009.02.009.

Xidonas, P.; Mavrotas, G.; Psarras, J. 2010 ${ }^{\mathrm{b}}$. Equity Portfolio Construction and Selection Using Multiobjective Mathematical Programming, Journal of Global Optimization 47: 185-209. doi: 10.1007/s10898-009-9465-4.

Xidonas, P.; Mavrotas, G.; Psarras, J. 2010 . Portfolio construction on the Athens Stock Exchange: a multiobjective optimization approach, Optimization 59(8): 1211-1229. doi: 10.1080/02331930903085375.

Yu, J-R.; Lee, W-Y. 2011. Portfolio rebalancing model using multiple criteria, European Journal of Operational Research 209: 166-175. doi: 10.1016/j.ejor.2010.09.018.

Yu, L.; Wang, S.; Lai, K. K. 2008. Neural Network-Based Mean-Variance-Skewness Model for Portfolio Selection, Computers \& Operations Research 35: 34-46. doi: 10.1016/j.cor.2006.02.012.

Zavadskas, E. K.; Kaklauskas, A. 1996. Pastaty sistemotechninis ivertinimas. Vilnius: Technika. 279 p.

Zavadskas, E. K.; Turskis Z. 2011. Multiple Criteria Decision Making (MCDM) Methods in Economics: an Overview, Technological and Economic Development of Economy, 17(2): 397-427. doi: 10.3846/20294913.2011.593291.

Zhang, D.; Chen, P.; Song, H. 2008. Stock market forecasting model based on a hybrid ARMA and support vector machines, International Conference on Management Science and Engineering, 15th Annual Conference Proceedings, 1312-1317.

Zhang, W-G.; Liu, Y-J.; Xu, W-J. 2012. A possibilistic mean-semivariance-entropy model for multi-period portfolio selection with transaction costs, European Journal of Operational Research 222: 341-349. doi: 10.1016/j.ejor.2012.04.023.

Zhang, W-G.; Xiao, W-L.; Xu, W-J. 2010a. A possibilistic portfolio adjusting model with new added assets, Economic Modelling 27: 208-213. doi: 10.1016/j.econmod.2009.08.008.

Zhang, W-G.; Zhang, X.; Chen, Y. 2011b. Portfolio adjusting optimization with added assets and transaction costs based on credibility measures, Insurance: Mathematics and Economics 49: 353-360. doi: 10.1016/j.insmatheco.2011.05.008. 
Zhang, W-G.; Zhang, X-L.; Xu, W-J. 2010b. A risk tolerance model for portfolio adjusting problem with transaction costs based on possibilistic moments, Insurance: Mathematics and Economics 46: 493-499. doi: 10.1016/j.insmatheco.2010.01.007.

Zhang, X.; Zhang, W-G.; Xu, W-J. 2011a. An optimization model of the portfolio adjusting problem with fuzzy return and a SMO algorithm, Expert Systems with Applications 38: 3069-3074. doi: 10.1016/j.eswa.2010.08.097.

Zhwang, Y-J.; Wei, Y-M. 2010. The crude oil market and the gold market: Evidence for cointegration, causality and price discovery, Resources Policy 35: 168-177. doi: 10.1016/j.resourpol.2010.05.003. 


\section{Autoriaus publikaciju disertacijos tema sąrašas}

\section{Straipsniai recenzuojamuose mokslo žurnaluose}

Žilinskij, G.; Rutkauskas A. V. 2012. Akcijų investiciniu patrauklumu paremtas investiciju portfelio sudarymo modelis, Verslas: teorija ir praktika [Business: Theory and Practice] 13(3): 242-252. doi:10.3846/btp.2012.26. (EBSCO, Business Source Complete)

Rutkauskas, A. V.; Žilinskij, G. 2010. Finansinio sverto naudojimas aktyviai valdant investiciju portfeli, Verslas: teorija ir praktika [Business: Theory and Practice] 11(3): 194-203. doi: 10.3846/btp.2010.22. (EBSCO, Business Source Complete)

\section{Straipsniai recenzuojamuose tarptautinių konferencijų medžiagose}

Žilinskij, G. 2012. Different period time series forecasts integration as a tool of increasing the accuracy of stock return prediction, 7-osios tarptautines mokslines konferencijos „Business and Management 2012“, ¿vvykusios Vilniuje $2012 \mathrm{~m}$. gegužès 10-11 d., medžiaga. Vilnius: Technika, 292-298. doi: 10.3846/bm.2012.039. ISBN 978609-457-116-9.

Žilinskij, G.; Kuzminskas, V. 2011. Widely diversified investment portfolio - a tool to protect your investment in terms of markets volatility, Proceedings of MMK 2011. International Masaryk conference for Ph.D. students and young researchers 2: 21402150. ISBN 978-80-904877-7-2. 


\section{Straipsniai kituose leidiniuose}

Žilinskij, G. 2009. Kapitalo rinkos teorijos taikymas aktyviam portfelio valdymui, Verslas XXI amžiuje: 12-osios Lietuvos jaunuju mokslininku konferencijos ,, Mokslas Lietuvos ateitis", ivykusios Vilniuje $2009 \mathrm{~m}$. vasario 5 d, pranešimai [CD]. Vilnius : VGTU Verslo vadybos fakultetas [1-8].

Žilinskij, G.; Dzikevičius, A. 2008. Markowitzo teorijos plètra siekiant adekvatesnio portfelio sudarymo ir valdymo, Verslas XXI amžiuje: 11-osios Lietuvos jaunuju mokslininku konferencijos „Mokslas - Lietuvos ateitis“, ivykusios Vilniuje, $2008 \mathrm{~m}$. vasario $7 d$, medžiaga. Vilnius: Technika, 23-30. ISBN 9789955283843. 


\section{Priedai}

A priedas. Koreliacijų matrica

B priedas. Aktyvų deriniai portfeliuose

C priedas. Portfelių vertès kitimas 2007-04-10-2011-02-10 laikotarpiu

D priedas. Kasdieniai portfelių vertès svyravimai 2011-02-10-2012-04-10 laikotarpiu

E priedas. Portfeliu pelningumas ir rizika

F priedas. Vidutinès kvadratinès indeksų/akcijų grąžos prognozavimo paklaidos

G priedas. Akcijų investiciniam patrauklumui (sprendimui dèl investavimo 2003-04-01-2004-04-01 laikotarpiui priimti) nustatyti taikytos kriterijų reikšmès

H priedas. Akcijų investiciniam patrauklumui (sprendimui dèl investavimo 2004-04-01-2005-04-01 laikotarpiui priimti) nustatyti taikytos kriterijų reikšmès

I priedas. Akcijų investiciniam patrauklumui (sprendimui dèl investavimo 2005-04-01-2006-04-01 laikotarpiui priimti) nustatyti taikytos kriterijų reikšmès

J priedas. Akcijų investiciniam patrauklumui (sprendimui dèl investavimo 2006-04-01-2007-04-01 laikotarpiui priimti) nustatyti taikytos kriterijų reikšmès 
K priedas. Akcijų investiciniam patrauklumui (sprendimui dèl investavimo 2007-04-01-2008-04-01 laikotarpiui priimti) nustatyti taikytos kriterijų reikšmès

L priedas. Akcijų investiciniam patrauklumui (sprendimui dẻl investavimo 2008-04-01-2009-04-01 laikotarpiui priimti) nustatyti taikytos kriterijų reikšmès

M priedas. Akcijų investiciniam patrauklumui (sprendimui dèl investavimo 2009-04-01-2010-04-01 laikotarpiui priimti) nustatyti taikytos kriterijų reikšmès

$\mathbf{N}$ priedas. Akcijų investiciniam patrauklumui (sprendimui dèl investavimo 2010-04-01-2011-04-01 laikotarpiui priimti) nustatyti taikytos kriterijų reikšmès

O priedas. Akcijų investiciniam patrauklumui (sprendimui dèl investavimo 2011-04-01-2012-04-01 laikotarpiui priimti) nustatyti taikytos kriterijų reikšmès

P priedas. Optimalios portfelių sudètys 


\section{A priedas. Koreliacijų matrica}

A.1 lentelè. Atskirų bižoje prekiaujamų fondų grąžos koreliacijų matrica, \%

Table A.1. Separate exchange traded funds' returns correlation matrix, \%

\begin{tabular}{|c|c|c|c|c|c|c|c|c|c|c|c|c|c|c|c|c|c|c|c|c|c|c|c|c|}
\hline & EWC & EZA & EPP & ILF & FEZ & SPY & GUR & GAF & BSV & BIV & BLV & FXA & FXY & FXC & FXB & FXE & FXS & FXM & UUP & GLD & SLV & DBB & DBE & DBA \\
\hline EWC & 1,00 & 0,77 & 0,90 & 0,90 & 0,82 & 0,85 & 0,83 & 0,81 & 0,10 & 0,31 & 0,19 & 0,86 & $-0,31$ & 0,87 & 0,49 & 0,44 & 0,68 & 0,74 & $-0,42$ & $-0,01$ & 0,43 & 0,72 & 0,72 & 0,64 \\
\hline EZA & 0,77 & 1,00 & 0,89 & 0,81 & 0,83 & 0,80 & 0,82 & 0,97 & 0,29 & 0,38 & 0,42 & 0,76 & $-0,12$ & 0,62 & 0,46 & 0,56 & 0,67 & 0,67 & $-0,54$ & 0,07 & 0,31 & 0,59 & 0,51 & 0,31 \\
\hline EPP & 0,90 & 0,89 & 1,00 & 0,93 & 0,91 & 0,91 & 0,93 & 0,92 & 0,14 & 0,32 & 0,25 & 0,87 & $-0,35$ & 0,73 & 0,47 & 0,52 & 0,69 & 0,75 & $-0,46$ & $-0,03$ & 0,36 & 0,72 & 0,61 & 0,49 \\
\hline ILF & 0,90 & 0,81 & 0,93 & 1,00 & 0,84 & 0,89 & 0,87 & 0,85 & 0,24 & 0,42 & 0,28 & 0,89 & $-0,32$ & 0,75 & 0,37 & 0,47 & 0,62 & 0,77 & $-0,39$ & $-0,03$ & 0,41 & 0,69 & 0,59 & 0,59 \\
\hline FEZ & 0,82 & 0,83 & 0,91 & 0,84 & 1,00 & 0,89 & 0,86 & 0,83 & 0,19 & 0,33 & 0,26 & 0,79 & $-0,19$ & 0,61 & 0,54 & 0,66 & 0,79 & 0,72 & $-0,59$ & $-0,06$ & 0,32 & 0,64 & 0,54 & 0,48 \\
\hline SPY & 0,85 & 0,80 & 0,91 & 0,89 & 0,89 & 1,00 & 0,80 & 0,83 & 0,21 & 0,38 & 0,28 & 0,75 & $-0,35$ & 0,59 & 0,36 & 0,35 & 0,58 & 0,84 & $-0,28$ & $-0,25$ & 0,22 & 0,61 & 0,48 & 0,46 \\
\hline GUR & 0,83 & 0,82 & 0,93 & 0,87 & 0,86 & 0,80 & 1,00 & 0,87 & 0,08 & 0,25 & 0,15 & 0,85 & $-0,42$ & 0,69 & 0,47 & 0,56 & 0,69 & 0,70 & $-0,47$ & 0,03 & 0,41 & 0,74 & 0,70 & 0,53 \\
\hline GAF & 0,81 & 0,97 & 0,92 & 0,85 & 0,83 & 0,83 & 0,87 & 1,00 & 0,28 & 0,39 & 0,37 & 0,80 & $-0,21$ & 0,66 & 0,46 & 0,52 & 0,65 & 0,73 & $-0,49$ & 0,05 & 0,35 & 0,66 & 0,58 & 0,37 \\
\hline BSV & 0,10 & 0,29 & 0,14 & 0,24 & 0,19 & 0,21 & 0,08 & 0,28 & 1,00 & 0,91 & 0,89 & 0,30 & 0,45 & 0,12 & $-0,06$ & 0,24 & 0,09 & 0,32 & $-0,17$ & 0,01 & 0,04 & 0,03 & $-0,10$ & 0,24 \\
\hline BIV & 0,31 & 0,38 & 0,32 & 0,42 & 0,33 & 0,38 & 0,25 & 0,39 & 0,91 & 1,00 & 0,89 & 0,48 & 0,28 & 0,27 & $-0,03$ & 0,25 & 0,16 & 0,46 & $-0,15$ & $-0,15$ & 0,06 & 0,18 & $-0,01$ & 0,35 \\
\hline BLV & 0,19 & 0,42 & 0,25 & 0,28 & 0,26 & 0,28 & 0,15 & 0,37 & 0,89 & 0,89 & 1,00 & 0,34 & 0,37 & 0,17 & $-0,03$ & 0,25 & 0,16 & 0,31 & $-0,22$ & $-0,03$ & $-0,05$ & 0,08 & $-0,07$ & 0,16 \\
\hline FXA & 0,86 & 0,76 & 0,87 & 0,89 & 0,79 & 0,75 & 0,85 & 0,80 & 0,30 & 0,48 & 0,34 & 1,00 & $-0,23$ & 0,81 & 0,52 & 0,64 & 0,70 & 0,73 & $-0,58$ & 0,11 & 0,54 & 0,77 & 0,66 & 0,71 \\
\hline FXY & $-0,31$ & $-0,12$ & $-0,35$ & $-0,32$ & $-0,19$ & $-0,35$ & $-0,42$ & $-0,21$ & 0,45 & 0,28 & 0,37 & $-0,23$ & 1,00 & $-0,20$ & 0,00 & 0,16 & 0,01 & $-0,35$ & $-0,27$ & 0,29 & 0,01 & $-0,39$ & $-0,31$ & $-0,14$ \\
\hline FXC & 0,87 & 0,62 & 0,73 & 0,75 & 0,61 & 0,59 & 0,69 & 0,66 & 0,12 & 0,27 & 0,17 & 0,81 & $-0,20$ & 1,00 & 0,46 & 0,43 & 0,58 & 0,53 & $-0,44$ & 0,18 & 0,50 & 0,69 & 0,71 & 0,65 \\
\hline FXB & 0,49 & 0,46 & 0,47 & 0,37 & 0,54 & 0,36 & 0,47 & 0,46 & $-0,06$ & $-0,03$ & $-0,03$ & 0,52 & 0,00 & 0,46 & 1,00 & 0,70 & 0,73 & 0,36 & $-0,76$ & 0,30 & 0,33 & 0,50 & 0,63 & 0,41 \\
\hline FXE & 0,44 & 0,56 & 0,52 & 0,47 & 0,66 & 0,35 & 0,56 & 0,52 & 0,24 & 0,25 & 0,25 & 0,64 & 0,16 & 0,43 & 0,70 & 1,00 & 0,84 & 0,35 & $-0,95$ & 0,41 & 0,45 & 0,56 & 0,51 & 0,45 \\
\hline FXS & 0,68 & 0,67 & 0,69 & 0,62 & 0,79 & 0,58 & 0,69 & 0,65 & 0,09 & 0,16 & 0,16 & 0,70 & 0,01 & 0,58 & 0,73 & 0,84 & 1,00 & 0,52 & $-0,85$ & 0,33 & 0,47 & 0,71 & 0,68 & 0,51 \\
\hline FXM & 0,74 & 0,67 & 0,75 & 0,77 & 0,72 & 0,84 & 0,70 & 0,73 & 0,32 & 0,46 & 0,31 & 0,73 & $-0,35$ & 0,53 & 0,36 & 0,35 & 0,52 & 1,00 & $-0,26$ & $-0,23$ & 0,13 & 0,62 & 0,51 & 0,50 \\
\hline UUP & $-0,42$ & $-0,54$ & $-0,46$ & $-0,39$ & $-0,59$ & $-0,28$ & $-0,47$ & $-0,49$ & $-0,17$ & $-0,15$ & $-0,22$ & $-0,58$ & $-0,27$ & $-0,44$ & $-0,76$ & $-0,95$ & $-0,85$ & $-0,26$ & 1,00 & $-0,52$ & $-0,47$ & $-0,55$ & $-0,52$ & $-0,41$ \\
\hline GLD & $-0,01$ & 0,07 & $-0,03$ & $-0,03$ & $-0,06$ & $-0,25$ & 0,03 & 0,05 & 0,01 & $-0,15$ & $-0,03$ & 0,11 & 0,29 & 0,18 & 0,30 & 0,41 & 0,33 & $-0,23$ & $-0,52$ & 1,00 & 0,67 & 0,20 & 0,28 & 0,17 \\
\hline SLV & 0,43 & 0,31 & 0,36 & 0,41 & 0,32 & 0,22 & 0,41 & 0,35 & 0,04 & 0,06 & $-0,05$ & 0,54 & 0,01 & 0,50 & 0,33 & 0,45 & 0,47 & 0,13 & $-0,47$ & 0,67 & 1,00 & 0,48 & 0,47 & 0,54 \\
\hline DBB & 0,72 & 0,59 & 0,72 & 0,69 & 0,64 & 0,61 & 0,74 & 0,66 & 0,03 & 0,18 & 0,08 & 0,77 & $-0,39$ & 0,69 & 0,50 & 0,56 & 0,71 & 0,62 & $-0,55$ & 0,20 & 0,48 & 1,00 & 0,70 & 0,61 \\
\hline DBE & 0,72 & 0,51 & 0,61 & 0,59 & 0,54 & 0,48 & 0,70 & 0,58 & $-0,10$ & $-0,01$ & $-0,07$ & 0,66 & $-0,31$ & 0,71 & 0,63 & 0,51 & 0,68 & 0,51 & $-0,52$ & 0,28 & 0,47 & 0,70 & 1,00 & 0,63 \\
\hline DBA & 0,64 & 0,31 & 0,49 & 0,59 & 0,48 & 0,46 & 0,53 & 0,37 & 0,24 & 0,35 & 0,16 & 0,71 & $-0,14$ & 0,65 & 0,41 & 0,45 & 0,51 & 0,50 & $-0,41$ & 0,17 & 0,54 & 0,61 & 0,63 & 1,00 \\
\hline & 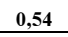 & 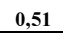 & 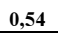 & 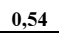 & 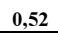 & 049 & 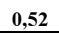 & 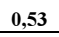 & 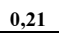 & 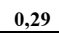 & 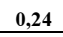 & 0,57 & & & & & & & & & & & & \\
\hline
\end{tabular}




\section{B priedas. Aktyvų deriniai portfeliuose}

B.1 lentelè. Aktyvų deriniai portfeliuose

Table B.1. Combinations of actives in portfolios

\begin{tabular}{|c|c|c|c|c|c|c|c|c|c|c|c|c|c|c|c|c|c|c|}
\hline \multirow{2}{*}{ Portfelis } & \multirow{2}{*}{ Grąža } & \multirow{2}{*}{ Rizika } & \multicolumn{16}{|c|}{ BPF svoris portfelyje } \\
\hline & & & EWC & EZA & EPP & ILF & BSV & BIV & FXA & FXY & FXB & FXE & FXs & UUP & GLD & SLV & DBB & DBE \\
\hline 1 & 0,0568 & 0,2671 & 0,0000 & 0,0026 & 0,0000 & 0,0000 & 0,0000 & 0,0000 & 0,0000 & 0,0875 & 0,0740 & 0,2580 & 0,0187 & 0,5133 & 0,0279 & 0,0000 & 0,0180 & 0,0000 \\
\hline 2 & 0,4370 & 0,7626 & 0,0114 & 0,0000 & 0,0157 & 0,0000 & 0,3922 & 0,0000 & 0,0247 & 0,1040 & 0,0000 & 0,0000 & 0,0414 & 0,2901 & 0,1095 & 0,0000 & 0,0036 & 0,0073 \\
\hline 3 & 0,6844 & 1,3108 & 0,0004 & 0,0000 & 0,0000 & 0,0789 & 0,2779 & 0,0000 & 0,0000 & 0,2082 & 0,0000 & 0,0000 & 0,0000 & 0,2387 & 0,1960 & 0,0000 & 0,0000 & 0,0000 \\
\hline 4 & 0,9504 & 2,1091 & 0,0000 & 0,0000 & 0,0000 & 0,1240 & 0,0000 & 0,0295 & 0,0000 & 0,3549 & 0,0000 & 0,0000 & 0,0000 & 0,1935 & 0,2981 & 0,0000 & 0,0000 & 0,0000 \\
\hline 5 & 1,2717 & 3,2131 & 0,0000 & 0,0000 & 0,0000 & 0,1576 & 0,0000 & 0,0000 & 0,0000 & 0,4242 & 0,0000 & 0,0000 & 0,0000 & 0,0000 & 0,4181 & 0,0000 & 0,0000 & 0,0000 \\
\hline 6 & 1,4225 & 3,8508 & 0,0000 & 0,0000 & 0,0000 & 0,1693 & 0,0000 & 0,0000 & 0,0000 & 0,2475 & 0,0000 & 0,0000 & 0,0000 & 0,0000 & 0,5831 & 0,0000 & 0,0000 & 0,0000 \\
\hline 7 & 1,5870 & 4,6770 & 0,0000 & 0,0000 & 0,0000 & 0,1821 & 0,0000 & 0,0000 & 0,0000 & 0,0547 & 0,0000 & 0,0000 & 0,0000 & 0,0000 & 0,7632 & 0,0000 & 0,0000 & 0,0000 \\
\hline 8 & 0,6053 & 4,6770 & \multicolumn{16}{|c|}{ Kiekvieno BPF svoris portfelyje lygus $1 / 24$} \\
\hline 9 & 1,7508 & 5,6969 & 0,0000 & 0,0000 & 0,0000 & 0,1077 & 0,0000 & 0,0000 & 0,0000 & 0,0000 & 0,0000 & 0,0000 & 0,0000 & 0,0000 & 0,6876 & 0,2047 & 0,0000 & 0,0000 \\
\hline 10 & 1,9435 & 7,3803 & 0,0000 & 0,0000 & 0,0000 & 0,0000 & 0,0000 & 0,0000 & 0,0000 & 0,0000 & 0,0000 & 0,0000 & 0,0000 & 0,0000 & 0,4495 & 0,5505 & 0,0000 & 0,0000 \\
\hline
\end{tabular}




\section{C priedas. Portfelių verčių kitimas 2007-04-10-2011-02-10 laikotarpiu}

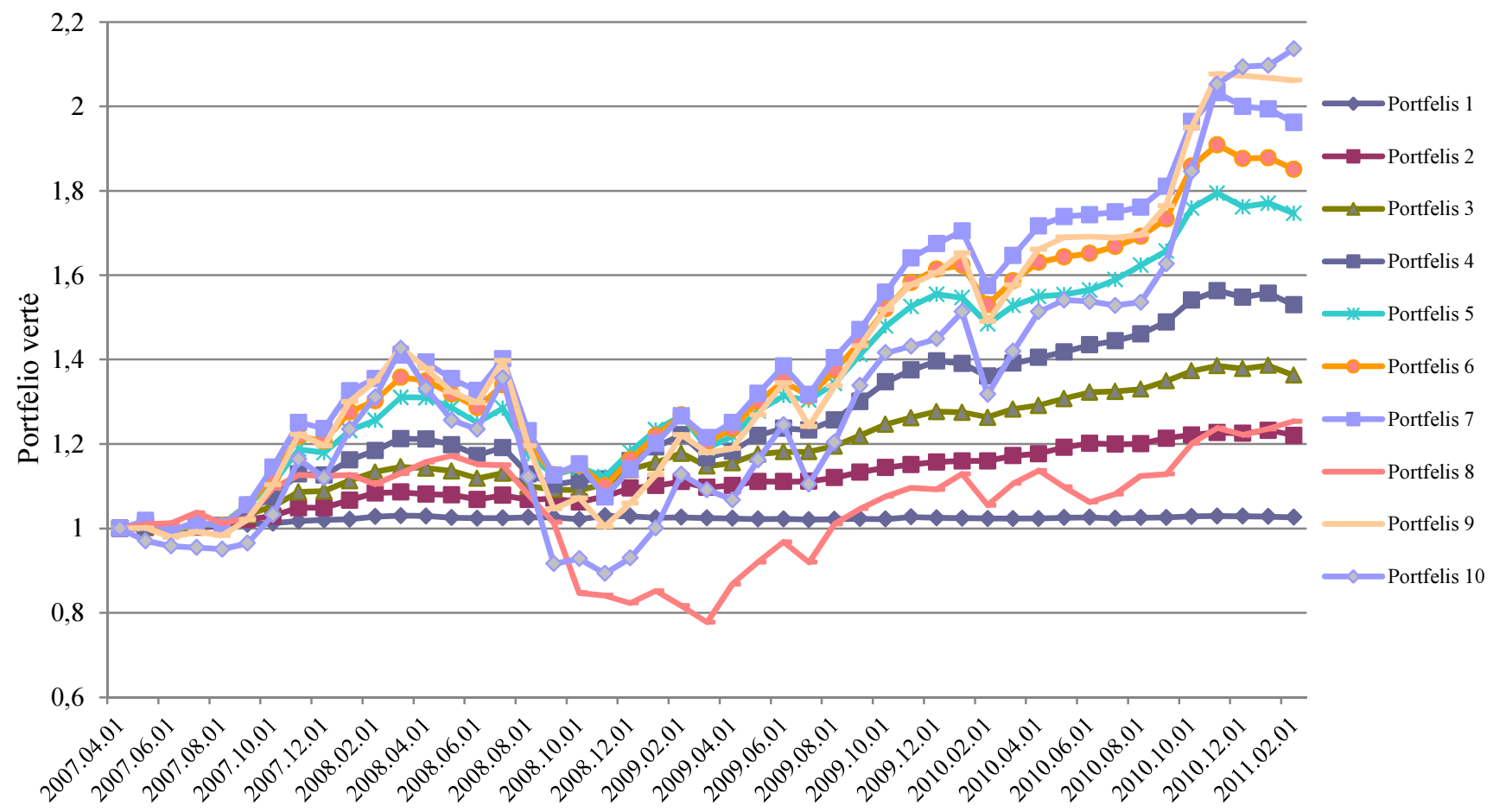

C.1 pav. Portfelių verčių kitimas 2007-04-10-2011-02-10 laikotarpiu

Fig. C.1. Portfolios' value changes in period 2007-04-10-2011-02-10 
D priedas. Kasdieniai portfelių verčių svyravimai 2011-02-10-2012-04-10 laikotarpiu

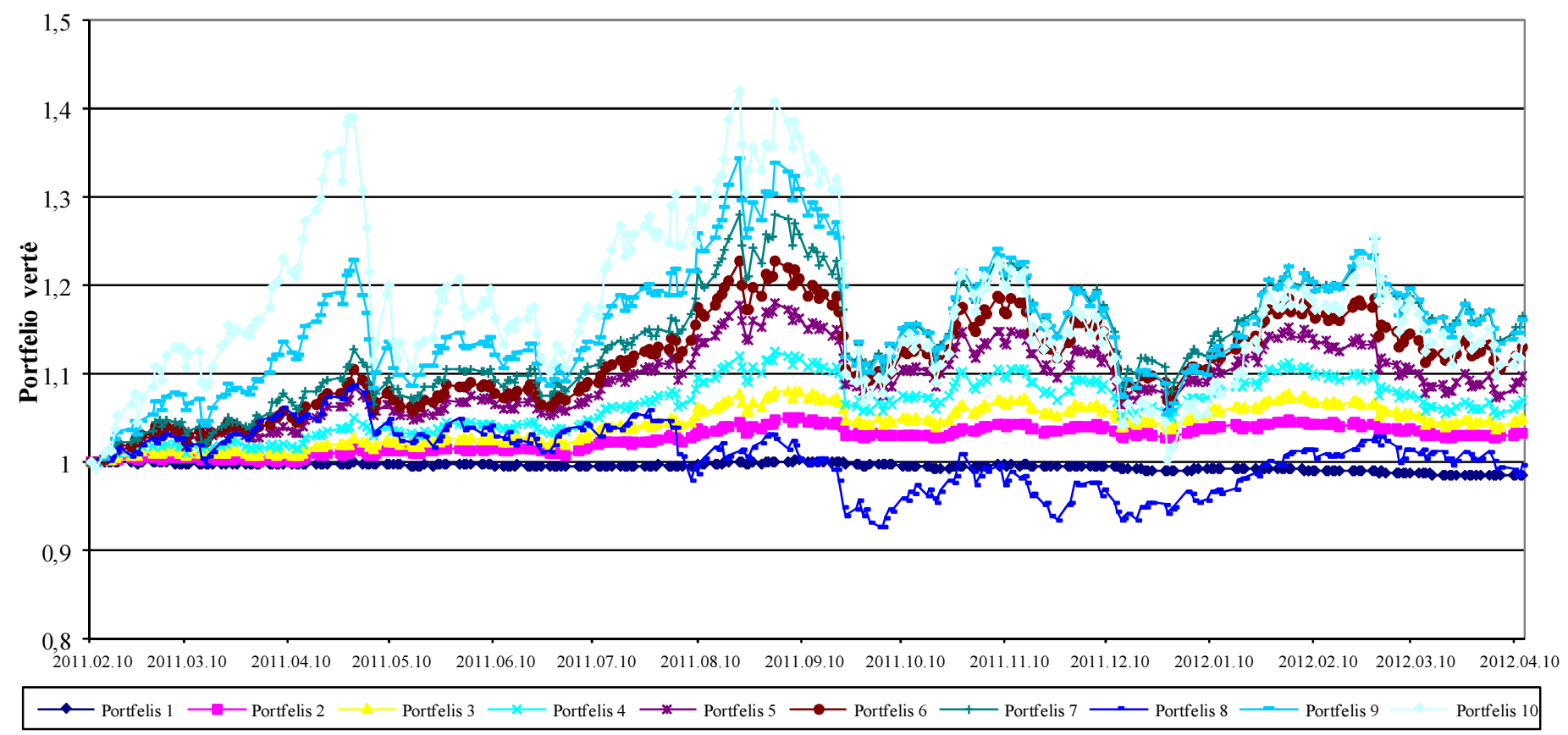

D.1 pav. Kasdieniai portfelių verčių svyravimai 2011-02-10-2012-04-10 laikotarpiu

Fig. D.1. Daily fluctuations of portfolios values in period 2011-02-10-2012-04-10 


\title{
E priedas. Portfelių pelningumas ir rizika
}

\author{
E.1 lentelè. Portfelių pelningumas ir rizika
}

Table E.1. Risk and return of portfolios

\begin{tabular}{|c|c|c|c|c|c|c|c|c|c|c|c|c|}
\hline \multicolumn{10}{|c|}{ Aktyviai valdomas portfelis } & \multicolumn{2}{|c|}{$\begin{array}{c}\text { Palyginamasis } \\
\text { portfelis }\end{array}$} & \multirow{2}{*}{$\begin{array}{c}\text { Skolinimas (-) } \\
\text { Skolinimasis } \\
(+)\end{array}$} \\
\hline APG & CTS & IVL & LNA & PTR & SAB & TEO & UKB & Grąža & Rizika & Grąža & Rizika & \\
\hline 0 & 0 & 0 & 0,349 & 0,651 & 0 & 0 & 0 & 1,65 & 2,79 & 0,66 & 2,32 & $-17 \%$ \\
\hline 0 & 0 & 0 & 0 & 0,522 & 0,478 & 0 & 0 & 1,32 & 3,14 & 0,50 & 2,37 & $-25 \%$ \\
\hline 0 & 0 & 0 & 0 & 0 & 1 & 0 & 0 & 1,06 & 2,24 & 0,14 & 2,50 & $12 \%$ \\
\hline 0 & 0 & 0 & 0 & 0 & 1 & 0 & 0 & 2,14 & 1,44 & 0,49 & 2,09 & $45 \%$ \\
\hline 0 & 0 & 0 & 0 & 0 & 1 & 0 & 0 & 1,01 & 2,64 & $-0,26$ & 1,88 & $-29 \%$ \\
\hline 0 & 0 & 0 & 0 & 0 & 0 & 0 & 0 & 0,00 & 0,00 & \begin{tabular}{|l|}
$-2,03$ \\
\end{tabular} & 1,75 & $-100 \%$ \\
\hline 0 & 0 & 0 & 0 & 0 & 0 & 0 & 0 & 0,00 & 0,00 & $-1,30$ & 2,74 & $-100 \%$ \\
\hline 0 & 0 & 0 & 0 & 0 & 0 & 0 & 0 & 0,00 & 0,00 & $-1,15$ & 2,74 & $-100 \%$ \\
\hline 0 & 0 & 0 & 1 & 0 & 0 & 0 & 0 & 0,38 & 1,38 & $-1,24$ & 2,76 & $70 \%$ \\
\hline 0 & 1 & 0 & 0 & 0 & 0 & 0 & 0 & 0,28 & 2,68 & $-1,15$ & 2,77 & $3 \%$ \\
\hline 0 & 1 & 0 & 0 & 0 & 0 & 0 & 0 & 0,97 & 1,53 & 0,02 & 1,76 & $15 \%$ \\
\hline 0 & 0 & 0 & 0 & 0 & 0 & 0 & 0 & 0,00 & 0,00 & $-0,66$ & 0,78 & $-100 \%$ \\
\hline 0 & 0 & 0 & 0 & 0 & 0 & 0 & 0 & 0,00 & 0,00 & $-0,57$ & 0,80 & $-100 \%$ \\
\hline 0 & 0 & 1 & 0 & 0 & 0 & 0 & 0 & 0,52 & 2,60 & $-0,82$ & 1,26 & $-51 \%$ \\
\hline 0 & 0 & 1 & 0 & 0 & 0 & 0 & 0 & 0,36 & 2,67 & $-0,74$ & 1,28 & $-52 \%$ \\
\hline 0 & 0,718 & 0,282 & 0 & 0 & 0 & 0 & 0 & 1,59 & 3,69 & $-0,19$ & 2,03 & $-45 \%$ \\
\hline 0 & 1 & 0 & 0 & 0 & 0 & 0 & 0 & 1,23 & 1,84 & $-0,17$ & 2,03 & $10 \%$ \\
\hline 0 & 0 & 0,878 & 0,122 & 0 & 0 & 0 & 0 & 3,01 & 8,10 & $-0,04$ & 2,03 & $-75 \%$ \\
\hline 0 & 0,125 & 0 & 0,238 & 0,338 & 0,275 & \begin{tabular}{|l|}
0,02 \\
\end{tabular} & \begin{tabular}{|l|}
0,004 \\
\end{tabular} & 0,38 & 0,00 & 0,73 & 1,27 & $70 \%$ \\
\hline 0,337 & 0 & 0,004 & 0 & 0,316 & 0,054 & \begin{tabular}{|l|l|}
0,165 \\
\end{tabular} & \begin{tabular}{|l|}
0,124 \\
\end{tabular} & 0,82 & 0,00 & 1,08 & 1,15 & $70 \%$ \\
\hline 0 & 0 & 0,042 & 0 & 0,495 & 0,455 & 0,008 & 0 & 0,68 & 0,31 & 0,39 & 0,60 & $70 \%$ \\
\hline 0 & 0 & 0,383 & 0,001 & 0,308 & 0 & \begin{tabular}{|l|}
0,308 \\
\end{tabular} & 0 & 2,39 & 0,51 & 0,69 & 0,64 & $26 \%$ \\
\hline 0 & 0 & 0,624 & 0 & 0 & 0 & \begin{tabular}{|l|l|}
0,281 \\
\end{tabular} & \begin{tabular}{|l|}
0,095 \\
\end{tabular} & 2,10 & 1,83 & 0,48 & 0,85 & $-54 \%$ \\
\hline 0 & 0 & 0,71 & 0 & 0,29 & 0 & 0 & 0 & 2,13 & 2,40 & 0,19 & 0,99 & $-59 \%$ \\
\hline 0,135 & 0 & 0,665 & 0 & 0 & 0,2 & 0 & 0 & 1,02 & 1,76 & $-0,02$ & 0,81 & $-54 \%$ \\
\hline 0 & 0 & 0 & 0 & 0 & 1 & 0 & 0 & 1,53 & 2,67 & $-0,40$ & 1,19 & $-55 \%$ \\
\hline 0 & 0 & 0 & 0 & 0 & 0 & 0 & 0 & 0,00 & 0,00 & $-2,82$ & 4,03 & $-100 \%$ \\
\hline 0 & 0 & 0 & 0 & 0 & 0 & 0 & 0 & 0,00 & 0,00 & $-2,36$ & 4,37 & $-100 \%$ \\
\hline 0 & 0 & 0 & 0 & 0 & 0 & 0 & 0 & 0,00 & 0,00 & $-2,95$ & 4,32 & $-100 \%$ \\
\hline 0 & 0 & 0 & 0 & 0 & 0 & 0 & 0 & 0,00 & 0,00 & $-2,30$ & 4,96 & $-100 \%$ \\
\hline 1 & 0 & 0 & 0 & 0 & 0 & 0 & 0 & 0,13 & 7,55 & $-2,52$ & 4,97 & $-34 \%$ \\
\hline 0,21 & 0 & 0,312 & 0 & 0 & 0 & \begin{tabular}{|l|l|}
0,478 \\
\end{tabular} & 0 & 0,47 & 3,00 & $-0,99$ & 3,00 & $0 \%$ \\
\hline 1 & 0 & 0 & 0 & 0 & 0 & 0 & 0 & 0,15 & 6,41 & $-1,68$ & 2,70 & $-58 \%$ \\
\hline 0 & 0 & 0 & 1 & 0 & 0 & 0 & 0 & 0,73 & 1,25 & $-1,18$ & 2,48 & $70 \%$ \\
\hline 0 & 0 & 0 & 1 & 0 & 0 & 0 & 0 & 1,04 & 1,43 & $-2,85$ & 1,21 & $-15 \%$ \\
\hline 0 & 0 & 0 & 1 & 0 & 0 & 0 & 0 & 2,72 & 3,68 & $-0,97$ & 3,74 & $2 \%$ \\
\hline 0 & 0 & 0 & 1 & 0 & 0 & 0 & 0 & 3,13 & 3,36 & $-0,15$ & 3,65 & $9 \%$ \\
\hline 0 & 0 & 0 & 1 & 0 & 0 & 0 & 0 & 4,85 & 3,38 & 0,56 & 3,59 & $6 \%$ \\
\hline 0 & 0 & 0 & 0,627 & 0 & 0 & 0 & \begin{tabular}{|l|}
0,373 \\
\end{tabular} & 2,57 & 3,47 & 1,03 & 3,47 & $0 \%$ \\
\hline 0,122 & 0 & 0 & 0,107 & 0 & 0,482 & 0 & \begin{tabular}{|l|}
0,289 \\
\end{tabular} & 2,50 & 0,72 & 1,94 & 2,18 & $70 \%$ \\
\hline 0,636 & 0,128 & 0,13 & 0 & 0 & 0 & 0 & 0,106 & 1,04 & 0,14 & 0,76 & 0,67 & $70 \%$ \\
\hline 0 & 0 & 0 & 0 & 0 & 0 & 0 & 0 & 0,00 & 0,00 & $-1,57$ & 4,56 & $-100 \%$ \\
\hline 0 & 0 & 0 & 0 & 0 & 0 & 0 & 0 & 0,00 & 0,00 & $-1,33$ & 4,56 & $-100 \%$ \\
\hline 0 & 0 & 0 & 0 & 0 & 0 & 0 & 0 & 0,00 & 0,00 & $-1,62$ & 4,64 & $-100 \%$ \\
\hline 0 & 0 & 0 & 0 & 0 & 0 & 0 & 0 & 0,00 & 0,00 & $-2,60$ & 4,76 & $-100 \%$ \\
\hline 0 & 0 & 0 & 0 & 0 & 0 & 0 & 0 & 0,00 & 0,00 & $-2,34$ & 4,93 & $-100 \%$ \\
\hline 0,12 & 0 & 0,768 & 0 & 0,112 & 0 & 0 & 0 & 0,98 & 3,04 & 0,26 & 2,90 & $-4 \%$ \\
\hline 1 & 0 & 0 & 0 & 0 & 0 & 0 & 0 & 0,77 & 2,56 & $-0,17$ & 2,63 & $3 \%$ \\
\hline 0,598 & 0,131 & 0 & 0 & 0,271 & 0 & 0 & 0 & 0,81 & 1,71 & 0,38 & 2,80 & $64 \%$ \\
\hline 0,293 & 0,067 & 0,113 & 0,12 & 0,088 & 0,175 & \begin{tabular}{|l|l|}
0,096 \\
\end{tabular} & \begin{tabular}{|l|}
0,048 \\
\end{tabular} & 1,76 & 0,00 & 1,73 & 0,61 & $70 \%$ \\
\hline 0 & 0 & 0 & 0,202 & 0 & 0 & \begin{tabular}{|l|}
0,473 \\
\end{tabular} & \begin{tabular}{|l|}
0,325 \\
\end{tabular} & 1,78 & 1,54 & 0,96 & 1,76 & $15 \%$ \\
\hline 0,088 & 0 & 0 & 0,338 & 0 & 0 & \begin{tabular}{|l|l|}
0,474 \\
\end{tabular} & 0,1 & 1,48 & 1,64 & 0,76 & 1,64 & $0 \%$ \\
\hline 0 & 0 & 0 & 0,913 & 0 & 0 & \begin{tabular}{|l}
0,016 \\
\end{tabular} & \begin{tabular}{|l|}
0,071 \\
\end{tabular} & 3,43 & 2,94 & 1,57 & 2,30 & $-22 \%$ \\
\hline 0,196 & 0 & 0 & 0 & 0 & 0 & \begin{tabular}{|l|l}
0,785 \\
\end{tabular} & \begin{tabular}{|l|}
0,019 \\
\end{tabular} & 1,14 & 1,38 & 0,96 & 2,42 & $70 \%$ \\
\hline 0 & 0 & 0 & 0 & 0 & 0,85 & \begin{tabular}{|l|}
0,15 \\
\end{tabular} & 0 & 1,47 & 2,49 & 0,45 & 2,49 & $0 \%$ \\
\hline 0,174 & 0 & 0,233 & 0 & 0 & 0 & 0,593 & 0 & 0,90 & 0,64 & 0,77 & 2,19 & $70 \%$ \\
\hline
\end{tabular}




\section{F priedas. Vidutinès kvadratinès indeksų/akciju grąžos prognozavimo paklaidos}

F.1 lentelè. Vidutinès kvadratinès indeksų/akcijų grąžos prognozavimo paklaidos

Table F.1. Mean square index/share return forecasting errors

\begin{tabular}{|c|c|c|c|c|c|c|c|c|c|c|}
\hline \multicolumn{11}{|c|}{ Paprastojo slenkančio vidurkio progozès } \\
\hline & Dow Jones & Nasdaq & $S \& P$ & $\boldsymbol{A} \boldsymbol{A}$ & $\boldsymbol{B} \boldsymbol{A}$ & $C A T$ & $D D$ & $G E$ & $I B M$ & KO \\
\hline Palyginamoji MSE & 1,437 & 3,943 & 1,964 & 10,605 & 6,248 & 7,019 & 5,532 & 6,150 & 5,025 & 3,389 \\
\hline $\operatorname{MSE}(n=1)$ & 1,405 & 3,573 & 1,847 & 11,125 & 6,552 & 7,118 & 5,698 & 6,341 & 4,879 & 3,325 \\
\hline MSE pokytis $(n=1)$ & $-2,18 \%$ & $-9,37 \%$ & $-5,93 \%$ & $4,90 \%$ & $4,86 \%$ & $1,41 \%$ & $3,00 \%$ & $3,11 \%$ & $-2,90 \%$ & $-1,90 \%$ \\
\hline $\operatorname{MSE}(n=2)$ & 1,200 & 3,141 & 1,586 & 8,865 & 5,295 & 5,865 & 4,566 & 5,100 & 4,145 & 2,815 \\
\hline MSE pokytis $(n=2)$ & $-16,51 \%$ & $-20,33 \%$ & $-18,14 \%$ & $-16,41 \%$ & $-15,25 \%$ & $-16,43 \%$ & $-17,47 \%$ & $-17,07 \%$ & $-17,51 \%$ & $-16,96 \%$ \\
\hline $\operatorname{MSE}(n=3)$ & 1,287 & 3,350 & 1,707 & 9,457 & 5,574 & 6,243 & 4,860 & 5,409 & 4,392 & 3,020 \\
\hline MSE pokytis $(n=3)$ & $-10,42 \%$ & $-15,03 \%$ & $-15,30 \%$ & $-10,83 \%$ & $-10,79 \%$ & $-11,06 \%$ & $-12,16 \%$ & $-12,05 \%$ & $-12,61 \%$ & $-10,91 \%$ \\
\hline \multicolumn{11}{|c|}{ Svertinio slenkančiojo vidurkio prognozès } \\
\hline & Dow Jones & Nasdaq & $S \& P$ & $\boldsymbol{A} \boldsymbol{A}$ & $\boldsymbol{B} \boldsymbol{A}$ & $C A T$ & $D D$ & $G E$ & IBM & KO \\
\hline Palyginamoji MSE & 1,477 & 4,210 & 2,048 & 10,989 & 6,505 & 7,292 & 5,759 & 6,379 & 5,243 & 3,503 \\
\hline $\operatorname{MSE}(n=1)$ & 1,325 & 3,449 & 1,762 & 10,608 & 6,265 & 6,755 & 5,437 & 6,040 & 4,680 & 3,175 \\
\hline MSE pokytis $(n=1)$ & $-10,32 \%$ & $-18,08 \%$ & $-13,98 \%$ & $-3,47 \%$ & $-3,69 \%$ & $-7,36 \%$ & $-5,59 \%$ & $-5,31 \%$ & $-10,74 \%$ & $-9,35 \%$ \\
\hline $\operatorname{MSE}(n=2)$ & 1,163 & 3,103 & 1,550 & 8,642 & 5,169 & 5,716 & 4,452 & 4,972 & 4,053 & 2,741 \\
\hline MSE pokytis $(n=2)$ & $-21,30 \%$ & $-26,28 \%$ & $-24,32 \%$ & $-21,36 \%$ & $-20,54 \%$ & $-21,61 \%$ & $-22,70 \%$ & $-22,06 \%$ & $-22,70 \%$ & $-21,74 \%$ \\
\hline $\operatorname{MSE}(n=3)$ & 1,284 & 3,414 & 1,718 & 9,489 & 5,604 & 6,271 & 4,884 & 5,427 & 4,417 & 3,021 \\
\hline MSE pokytis $(n=3)$ & $-13,09 \%$ & $-18,89 \%$ & $-16,10 \%$ & $-13,65 \%$ & $-13,85 \%$ & $-14,01 \%$ & $-15,21 \%$ & $-14,93 \%$ & $-15,76 \%$ & $-13,74 \%$ \\
\hline
\end{tabular}




\section{G priedas. Akciju investiciniam patrauklumui (sprendimui dèl investavimo 2003-04-01-2004-04-01 laikotarpiui priimti) nustatyti taikytos kriteriju reikšmès}

G.1 lentelè. Akcijų investiciniam patrauklumui (sprendimui dèl investavimo 2003-04-01-2004-04-01 laikotarpiui priimti) nustatyti taikytos kriterijų reikšmès

Table G.1. Values of criterions used to evaluate stocks' investment attractiveness for 2003-04-01-2004-04-01 investment period

\begin{tabular}{|c|c|c|c|c|c|c|c|c|c|c|c|c|c|c|c|c|c|c|}
\hline \multirow{2}{*}{$\begin{array}{c}\text { Kriterijaus } \\
\text { Nr. }\end{array}$} & \multicolumn{18}{|c|}{ Analizuojamos akcijos } \\
\hline & AA & BA & CAT & CVX & DD & GE & IBM & INTC & JNJ & KO & MCD & МММ & MRK & PFE & $\mathbf{T}$ & UTX & $\mathbf{V Z}$ & ХOM \\
\hline 1 & $-47,17 \%$ & $-45,38 \%$ & $-10,06 \%$ & $-24,14 \%$ & $-13,19 \%$ & $-27,91 \%$ & $-22,85 \%$ & $-47,07 \%$ & $-8,25 \%$ & $-21,38 \%$ & $-47,70 \%$ & $15,78 \%$ & $-0,83 \%$ & $-19,18 \%$ & $-39,43 \%$ & $-19,54 \%$ & $-18,39 \%$ & $-16,57 \%$ \\
\hline 2 & $-11,37 \%$ & $-7,10 \%$ & $-1,47 \%$ & $-6,78 \%$ & $-3,35 \%$ & $4,60 \%$ & $-5,45 \%$ & $0,83 \%$ & $10,00 \%$ & $-2,64 \%$ & $3,63 \%$ & $1,55 \%$ & $8,53 \%$ & $0,34 \%$ & $-6,03 \%$ & $1,11 \%$ & $0,65 \%$ & $-4,21 \%$ \\
\hline 3 & $5,99 \%$ & $7,39 \%$ & $9,13 \%$ & $4,57 \%$ & $8,56 \%$ & $21,33 \%$ & $8,37 \%$ & $16,10 \%$ & $26,85 \%$ & $30,93 \%$ & $14,34 \%$ & $18,89 \%$ & $20,72 \%$ & $36,93 \%$ & $25,74 \%$ & $12,14 \%$ & $9,99 \%$ & $8,86 \%$ \\
\hline 4 & $-26,38 \%$ & $-9,06 \%$ & $-4,57 \%$ & $-38,04 \%$ & $-56,95 \%$ & $-7,25 \%$ & $-24,73 \%$ & $-7,87 \%$ & $15,01 \%$ & $-3,85 \%$ & $-20,16 \%$ & $18,51 \%$ & $-2,84 \%$ & $1015,74 \%$ & $-7,28 \%$ & $5,22 \%$ & $12,62 \%$ & $13,29 \%$ \\
\hline 5 & $2,46 \%$ & $4,29 \%$ & $3,96 \%$ & $1,14 \%$ & $7,51 \%$ & $11,49 \%$ & $6,57 \%$ & $11,65 \%$ & $18,17 \%$ & $20,32 \%$ & $6,44 \%$ & $12,09 \%$ & $13,80 \%$ & $28,36 \%$ & $17,32 \%$ & $7,93 \%$ & $6,78 \%$ & $5,38 \%$ \\
\hline 6 & $-4,21 \%$ & $-5,97 \%$ & $1,03 \%$ & $8,21 \%$ & $262,43 \%$ & $1,64 \%$ & $7,93 \%$ & $-8,51 \%$ & $-4,07 \%$ & $-17,07 \%$ & $11,98 \%$ & $-8,13 \%$ & $-4,57 \%$ & $-2,25 \%$ & $-4,44 \%$ & $-10,17 \%$ & $-0,76 \%$ & $3,38 \%$ \\
\hline 7 & $5,11 \%$ & $8,27 \%$ & $7,14 \%$ & $-0,27 \%$ & $-14,14 \%$ & $16,21 \%$ & $9,25 \%$ & $-0,41 \%$ & $5,38 \%$ & $9,28 \%$ & $6,39 \%$ & $4,93 \%$ & $8,07 \%$ & $18,42 \%$ & $-1,31 \%$ & $7,86 \%$ & $-1,95 \%$ & $6,61 \%$ \\
\hline 8 & $-15,68 \%$ & $-14,20 \%$ & $-8,04 \%$ & $-6,52 \%$ & $12,56 \%$ & $-9,99 \%$ & $-13,46 \%$ & $1,24 \%$ & $4,39 \%$ & $-10,90 \%$ & $-2,59 \%$ & $-3,21 \%$ & $0,43 \%$ & $-15,26 \%$ & $-4,79 \%$ & $-6,26 \%$ & $2,66 \%$ & $-10,15 \%$ \\
\hline 9 & $-46,37 \%$ & $-79,50 \%$ & $0,29 \%$ & $-64,62 \%$ & $-130,26 \%$ & $-8,30 \%$ & $-55,73 \%$ & $148,14 \%$ & $6,75 \%$ & $\mid-31,40 \%$ & $-48,50 \%$ & $43,92 \%$ & $-11,45 \%$ & $5,34 \%$ & $-25,22 \%$ & $13,84 \%$ & $980,39 \%$ & $-27,14 \%$ \\
\hline 10 & 2,00 & 5,80 & 5,00 & 1,45 & 2,82 & 8,03 & 3,24 & 0,25 & 0,79 & 1,08 & 1,33 & 1,56 & 1,61 & 1,32 & 1,86 & 2,48 & 4,13 & 3,39 \\
\hline 11 & 1,42 & 0,85 & 1,29 & 0,89 & 1,90 & 0,80 & 1,21 & 2,87 & 1,68 & 1,00 & 0,71 & 1,36 & 1,20 & 1,34 & 0,96 & 1,49 & 0,77 & 1,15 \\
\hline 12 & 0,07 & 0,13 & 0,14 & 0,12 & 0,05 & 0,10 & 0,09 & 0,06 & 0,05 & 0,04 & 0,09 & 0,06 & 0,08 & 0,05 & 0,07 & 0,09 & 0,20 & 0,08 \\
\hline 13 & 2,55 & 4,33 & 3,02 & 2,69 & 4,87 & 4,87 & 6,36 & 4,32 & 7,54 & 10,42 & 2,99 & 7,93 & 6,67 & 10,76 & 6,19 & 3,68 & 3,32 & 3,39 \\
\hline 14 & 55,35 & 67,80 & 20,71 & 75,27 & 77,21 & 21,98 & 40,50 & 49,09 & 25,92 & 40,32 & 34,36 & 24,11 & 16,97 & 23,52 & 36,36 & 13,90 & 26,58 & 22,04 \\
\hline 15 & $40,19 \%$ & $34,05 \%$ & $16,65 \%$ & $12,57 \%$ & $15,23 \%$ & $29,36 \%$ & $35,98 \%$ & $65,65 \%$ & $26,18 \%$ & $14,46 \%$ & $33,28 \%$ & $15,98 \%$ & $17,08 \%$ & $22,16 \%$ & $18,80 \%$ & $22,32 \%$ & $16,72 \%$ & $11,68 \%$ \\
\hline 16 & $9,85 \%$ & $-8,07 \%$ & $0,98 \%$ & $16,39 \%$ & $1,17 \%$ & $33,83 \%$ & $6,91 \%$ & $-4,82 \%$ & $32,23 \%$ & $-2,98 \%$ & $7,67 \%$ & $55,70 \%$ & $6,12 \%$ & $22,90 \%$ & $24,05 \%$ & $12,41 \%$ & $75,33 \%$ & $35,76 \%$ \\
\hline 17 & $2,62 \%$ & $2,49 \%$ & $1,33 \%$ & $2,23 \%$ & $3,29 \%$ & $2,51 \%$ & $0,71 \%$ & $0,43 \%$ & $1,45 \%$ & $2,03 \%$ & $1,37 \%$ & $1,00 \%$ & $2,46 \%$ & $1,76 \%$ & $4,62 \%$ & $0,79 \%$ & $4,12 \%$ & $2,61 \%$ \\
\hline 18 & $-35,80 \%$ & $-38,29 \%$ & $-8,59 \%$ & $-17,36 \%$ & $-9,84 \%$ & $-32,51 \%$ & $-17,40 \%$ & $-47,90 \%$ & $-18,25 \%$ & $-18,74 \%$ & $-51,33 \%$ & $14,23 \%$ & $-9,36 \%$ & $-19,52 \%$ & $-33,40 \%$ & $-20,65 \%$ & $-19,05 \%$ & $-12,36 \%$ \\
\hline
\end{tabular}


$\mathrm{H}$ priedas. Akcijų investiciniam patrauklumui (sprendimui dèl investavimo 2004-04-01-2005-04-01 laikotarpiui priimti) nustatyti taikytos kriteriju reikšmès

H.1 lentelè. Akcijų investiciniam patrauklumui (sprendimui dèl investavimo 2004-04-01-2005-04-01 laikotarpiui priimti) nustatyti taikytos kriterijų reikšmès

Table H.1. Values of criterions used to evaluate stocks' investment attractiveness for 2004-04-01-2005-04-01 investment period

\begin{tabular}{|c|c|c|c|c|c|c|c|c|c|c|c|c|c|c|c|c|c|c|}
\hline \multirow{2}{*}{$\begin{array}{c}\text { Kriterijaus } \\
\mathrm{Nr} .\end{array}$} & \multicolumn{18}{|c|}{ Analizuojamos akcijos } \\
\hline & $\mathbf{A A}$ & BA & CAT & CVX & DD & GE & IBM & INTC & JNJ & KO & MCD & MMM & MRK & PFE & $T$ & UTX & $\mathbf{V Z}$ & XOM \\
\hline 1 & $82,33 \%$ & $1,89 \%$ & $62,68 \%$ & $39,59 \%$ & $12,00 \%$ & $20,17 \%$ & $18,18 \%$ & $67,32 \%$ & $-11,93 \%$ & $27,69 \%$ & $108,88 \%$ & $26,21 \%$ & $-12,26 \%$ & $13,68 \%$ & $22,62 \%$ & $49,28 \%$ & $6,82 \%$ & $19,69 \%$ \\
\hline 2 & $6,12 \%$ & $62 \%$ & $12,95 \%$ & $22,93 \%$ & $13,09 \%$ & $1,89 \%$ & $9,78 \%$ & $12,63 \%$ & $5,32 \%$ & $57 \%$ & $11,23 \%$ & $11,64 \%$ & $-56,57 \%$ & $39,60 \%$ & $-5,33 \%$ & $10,00 \%$ & $0,18 \%$ & $20,65 \%$ \\
\hline 3 & $8,77 \%$ & $1,71 \%$ & $9,24 \%$ & $10,30 \%$ & $-0,59 \%$ & $22,02 \%$ & $11,32 \%$ & $24,88 \%$ & $24,20 \%$ & $27,61 \%$ & $17,78 \%$ & $20,52 \%$ & $40,64 \%$ & $11,14 \%$ & $20,38 \%$ & $11,39 \%$ & $10,75 \%$ & $10,89 \%$ \\
\hline 4 & $0,53 \%$ & $7,97 \%$ & $13,10 \%$ & $86,43 \%$ & $45,87 \%$ & $6,38 \%$ & $30,46 \%$ & $26,52 \%$ & $11,43 \%$ & $0,31 \%$ & $25,57 \%$ & $17,13 \%$ & $-11,71 \%$ & $-25,32 \%$ & $-11,77 \%$ & $5,91 \%$ & $-9,26 \%$ & $11,90 \%$ \\
\hline 5 & $4,81 \%$ & $1,42 \%$ & $4,83 \%$ & $6,10 \%$ & $3,61 \%$ & $11,62 \%$ & $8,54 \%$ & $18,72 \%$ & $17,19 \%$ & $20,66 \%$ & $8,80 \%$ & $13,18 \%$ & $29,31 \%$ & $3,63 \%$ & $14,62 \%$ & $7,61 \%$ & $5,18 \%$ & $8,49 \%$ \\
\hline 6 & $-16,50 \%$ & $27,35 \%$ & $-8,86 \%$ & $-19,55 \%$ & $21,46 \%$ & $4,44 \%$ & \begin{tabular}{|l|l|}
$-9,69 \%$ \\
\end{tabular} & $-7,61 \%$ & $4,58 \%$ & $7,28 \%$ & $-8,32 \%$ & $-3,21 \%$ & $153,09 \%$ & $32,79 \%$ & $175,65 \%$ & $-1,61 \%$ & $104,08 \%$ & $-2,78 \%$ \\
\hline 7 & $6,37 \%$ & $1,34 \%$ & $11,02 \%$ & $5,31 \%$ & $6,99 \%$ & $12,56 \%$ & $8,27 \%$ & $6,60 \%$ & $18,98 \%$ & $11,59 \%$ & $6,51 \%$ & $14,81 \%$ & $-14,66 \%$ & $151,90 \%$ & $5,38 \%$ & $19,11 \%$ & $-0,90 \%$ & $14,18 \%$ \\
\hline 8 & $-0,24 \%$ & $-7,85 \%$ & $1,74 \%$ & $16,73 \%$ & $5,70 \%$ & $-9,48 \%$ & $1,39 \%$ & $5,65 \%$ & $-3,08 \%$ & $-3,61 \%$ & $4,43 \%$ & $-2,76 \%$ & $-49,12 \%$ & $-44,58 \%$ & $-10,16 \%$ & $-7,65 \%$ & $1,08 \%$ & $5,67 \%$ \\
\hline 9 & $83,15 \%$ & $70,72 \%$ & $32,24 \%$ & $517,77 \%$ & $08,26 \%$ & $-11,88 \%$ & $93,96 \%$ & $75,79 \%$ & $3,28 \%$ & $27,64 \%$ & $46,12 \%$ & $6,03 \%$ & $-3,15 \%$ & $-80,81 \%$ & $38,48 \%$ & $-11,74 \%$ & $-25,57 \%$ & $68,58 \%$ \\
\hline 10 & 1,63 & 5,52 & 5,00 & 1,24 & 2,79 & 7,18 & 2,75 & 0,25 & 0,80 & 0,94 & 1,13 & 1,23 & 1,61 & 0,79 & 1,62 & 1,96 & 3,96 & 2,64 \\
\hline 11 & 1,33 & 0,94 & 1,33 & 1,21 & 1,42 & 0,87 & 1,19 & 3,33 & 1,71 & 1,06 & 0,76 & 1,52 & 1,20 & 1,26 & 0,98 & 1,20 & 0,69 & 1,20 \\
\hline 12 & 11 & 0,14 & 10 & 0,02 & 0,06 & 0,11 & 0,10 & 0,08 & 0,07 & 0,05 & 0,13 & 0,0 & 0,0 & 0,05 & 0,21 & 0,0 & 0,23 & 0,12 \\
\hline 13 & 1,88 & 3,44 & 3,44 & 2,08 & 4,33 & 3,56 & 5,18 & 4,05 & 5,81 & 7,64 & 2,12 & 6,84 & 7,60 & 3,73 & 1,69 & 3,20 & 2,96 & 2,64 \\
\hline 14 & 25,39 & 38,98 & 19,00 & 10,46 & 42,93 & 18,82 & 19,03 & 27,15 & 21,68 & 24,74 & 17,32 & 22,48 & 17,33 & 62,24 & 7,61 & 16,00 & 32,12 & 11,03 \\
\hline 15 & $49,36 \%$ & $39,37 \%$ & $27,38 \%$ & $20,63 \%$ & $16,50 \%$ & $27,63 \%$ & $23,73 \%$ & $67,10 \%$ & $26,56 \%$ & $19,10 \%$ & $55,19 \%$ & $6,38 \%$ & $12,06 \%$ & $12,99 \%$ & $20,13 \%$ & $23,85 \%$ & $16,87 \%$ & $13,34 \%$ \\
\hline 16 & $11,02 \%$ & $4,39 \%$ & $12,34 \%$ & $1,81 \%$ & $4,62 \%$ & $-7,68 \%$ & $5,89 \%$ & $24,84 \%$ & $-3,30 \%$ & $16,94 \%$ & $15,19 \%$ & $5,36 \%$ & $20,32 \%$ & $0,26 \%$ & $8,69 \%$ & $37,82 \%$ & $7,62 \%$ & $7,15 \%$ \\
\hline 17 & $1,95 \%$ & $1,59 \%$ & $0,93 \%$ & $1,58 \%$ & $3,26 \%$ & $2,60 \%$ & $0,73 \%$ & $0,39 \%$ & $1,78 \%$ & $1,80 \%$ & $1,47 \%$ & $1,56 \%$ & $9,25 \%$ & $1,73 \%$ & $5,67 \%$ & $0,72 \%$ & $4,08 \%$ & $2,35 \%$ \\
\hline 18 & $76,21 \%$ & $68,51 \%$ & $49,72 \%$ & $16,66 \%$ & $-1,09 \%$ & $18,28 \%$ & $8,40 \%$ & $54,69 \%$ & $-27,24 \%$ & $20,12 \%$ & $97,65 \%$ & $14,58 \%$ & $44,31 \%$ & $-25,92 \%$ & $27,95 \%$ & $39,28 \%$ & $6,64 \%$ & $-0,96 \%$ \\
\hline
\end{tabular}




\section{I priedas. Akcijų investiciniam patrauklumui (sprendimui dèl investavimo 2005- 04-01-2006-04-01 laikotarpiui priimti) nustatyti taikytos kriterijų reikšmès}

I.1 lentelè. Akcijų investiciniam patrauklumui (sprendimui dèl investavimo 2005-04-01-2006-04-01 laikotarpiui priimti) nustatyti taikytos kriterijų reikšmès

Table I.1. Values of criterions used to evaluate stocks' investment attractiveness for 2005-04-01-2006-04-01 investment period

\begin{tabular}{|c|c|c|c|c|c|c|c|c|c|c|c|c|c|c|c|c|c|c|}
\hline \multirow{2}{*}{$\begin{array}{c}\text { Kriterijaus } \\
\text { Nr. }\end{array}$} & \multicolumn{18}{|c|}{ Analizuojamos akcijos } \\
\hline & AA & BA & CAT & CVX & DD & GE & IBM & INTC & JNJ & KO & MCD & MMM & MRK & PFE & $\mathbf{T}$ & UTX & $\mathbf{V Z}$ & XOM \\
\hline 1 & $-10,90 \%$ & $46,68 \%$ & $16,31 \%$ & $39,05 \%$ & $22,48 \%$ & $18,69 \%$ & $-1,31 \%$ & $-15,27 \%$ & $34,91 \%$ & $-16,24 \%$ & $9,23 \%$ & $6,98 \%$ & $-24,78 \%$ & $-24,77 \%$ & $0,55 \%$ & $18,47 \%$ & $-0,71 \%$ & $49,18 \%$ \\
\hline 2 & $9,21 \%$ & $3,90 \%$ & $32,91 \%$ & $27,55 \%$ & $0,97 \%$ & $13,54 \%$ & $8,03 \%$ & $13,50 \%$ & $13,12 \%$ & $4,37 \%$ & $-88,88 \%$ & $9,76 \%$ & $2,00 \%$ & $16,22 \%$ & $-0,12 \%$ & $20,69 \%$ & $5,21 \%$ & $20,79 \%$ \\
\hline 3 & $10,19 \%$ & $4,28 \%$ & $10,75 \%$ & $12,36 \%$ & $4,10 \%$ & $20,92 \%$ & $11,58 \%$ & $30,49 \%$ & $27,54 \%$ & $29,60 \%$ & $19,68 \%$ & $23,11 \%$ & $34,57 \%$ & $27,43 \%$ & $17,81 \%$ & \begin{tabular}{|l|l|}
$9,95 \%$ \\
\end{tabular} & $20,77 \%$ & $13,70 \%$ \\
\hline 4 & $16,61 \%$ & $47,87 \%$ & $37,01 \%$ & $39,57 \%$ & $51,57 \%$ & $9,19 \%$ & $8,65 \%$ & $20,65 \%$ & $22,37 \%$ & $12,12 \%$ & $22,68 \%$ & $19,57 \%$ & $-10,50 \%$ & $132,89 \%$ & $-12,62 \%$ & $16,29 \%$ & $34,81 \%$ & $27,44 \%$ \\
\hline 5 & $5,97 \%$ & $3,47 \%$ & $6,73 \%$ & $8,39 \%$ & $6,36 \%$ & $10,89 \%$ & $8,77 \%$ & $21,97 \%$ & $17,97 \%$ & $22,07 \%$ & $11,95 \%$ & $14,94 \%$ & $25,34 \%$ & $21,58 \%$ & $12,21 \%$ & $7,45 \%$ & $10,19 \%$ & $8,50 \%$ \\
\hline 6 & $-9,17 \%$ & $-6,02 \%$ & $-0,90 \%$ & $-14,31 \%$ & $-11,20 \%$ & $-2,13 \%$ & $-0,20 \%$ & $-13,98 \%$ & $-5,08 \%$ & $0,42 \%$ & $856,89 \%$ & $-5,06 \%$ & $10,43 \%$ & $-13,74 \%$ & $1,83 \%$ & $7,04 \%$ & $-18,15 \%$ & $-13,80 \%$ \\
\hline 7 & $2,84 \%$ & $1,73 \%$ & $18,15 \%$ & $14,41 \%$ & $-3,81 \%$ & $15,88 \%$ & $4,52 \%$ & $2,12 \%$ & $10,48 \%$ & $14,59 \%$ & $9,05 \%$ & $17,67 \%$ & $4,88 \%$ & $5,91 \%$ & $8,66 \%$ & $15,53 \%$ & $-0,01 \%$ & $12,04 \%$ \\
\hline 8 & $6,20 \%$ & $2,13 \%$ & $12,49 \%$ & $11,48 \%$ & $4,97 \%$ & $-2,02 \%$ & $3,36 \%$ & $11,15 \%$ & $2,38 \%$ & $-8,92 \%$ & $-89,80 \%$ & $-6,72 \%$ & $-2,74 \%$ & $9,74 \%$ & $-8,08 \%$ & $4,47 \%$ & $5,22 \%$ & $7,81 \%$ \\
\hline 9 & $27,50 \%$ & $112,32 \%$ & $58,08 \%$ & $53,55 \%$ & $63,65 \%$ & $-16,59 \%$ & $-2,24 \%$ & $27,91 \%$ & $-0,16 \%$ & $-3,88 \%$ & $31,88 \%$ & $-5,35 \%$ & $-12,58 \%$ & $85,48 \%$ & $-37,20 \%$ & $-6,96 \%$ & $136,54 \%$ & $1,87 \%$ \\
\hline 10 & 1,45 & 3,78 & 4,77 & 1,06 & 2,13 & 5,80 & 2,67 & 0,25 & 0,68 & 0,97 & 0,96 & 1,00 & 1,46 & 0,81 & 1,69 & 1,86 & 3,42 & 3,85 \\
\hline 11 & 1,19 & 0,72 & 1,29 & 1,52 & 1,92 & 0,85 & 1,18 & 3,00 & 1,96 & 1,10 & 0,81 & 1,44 & 1,15 & 1,50 & 0,45 & 1,20 & 0,84 & 1,40 \\
\hline 12 & 0,08 & 0,09 & $-0,15$ & 0,14 & 0,07 & 0,10 & 0,10 & 0,08 & 0,07 & 0,05 & 0,11 & 0,07 & 0,09 & 0,07 & 0,21 & 0,08 & 0,21 & 0,14 \\
\hline 13 & 2,17 & 3,52 & 3,66 & 2,23 & 3,89 & 3,16 & 5,02 & 4,14 & 5,22 & 7,02 & 2,49 & 6,10 & 5,37 & 3,62 & 1,41 & 3,36 & 2,82 & 2,85 \\
\hline 14 & 21,93 & 21,22 & 13,40 & 7,57 & 24,51 & 20,98 & 17,72 & 21,26 & 19,51 & 23,07 & 15,51 & 21,18 & 15,98 & 21,68 & 9,72 & 16,89 & 13,54 & 11,36 \\
\hline 15 & $42,38 \%$ & $41,52 \%$ & $24,30 \%$ & $24,72 \%$ & $19,21 \%$ & $19,97 \%$ & $16,45 \%$ & $46,57 \%$ & $24,12 \%$ & $18,76 \%$ & $54,36 \%$ & $6,17 \%$ & $13,82 \%$ & $14,79 \%$ & $20,40 \%$ & $22,61 \%$ & $10,60 \%$ & $21,78 \%$ \\
\hline 16 & $16,29 \%$ & $-16,73 \%$ & $3,00 \%$ & $-2,13 \%$ & $2,42 \%$ & $-0,62 \%$ & $-35,10 \%$ & $-4,10 \%$ & $-1,29 \%$ & $-3,36 \%$ & $26,96 \%$ & $8,01 \%$ & $-7,72 \%$ & $53,61 \%$ & $31,81 \%$ & $0,69 \%$ & $41,03 \%$ & $1,62 \%$ \\
\hline 17 & $2,07 \%$ & $1,43 \%$ & $0,91 \%$ & $3,01 \%$ & $2,97 \%$ & $2,32 \%$ & $0,94 \%$ & $0,85 \%$ & $1,66 \%$ & $2,37 \%$ & $1,88 \%$ & $1,96 \%$ & $4,45 \%$ & $2,58 \%$ & $5,30 \%$ & $0,73 \%$ & $4,30 \%$ & $1,89 \%$ \\
\hline 18 & $-20,10 \%$ & $42,78 \%$ & $-16,60 \%$ & $11,50 \%$ & $21,51 \%$ & $5,15 \%$ & $-9,34 \%$ & $-28,77 \%$ & $21,80 \%$ & $-20,61 \%$ & $98,11 \%$ & $-2,79 \%$ & $-26,78 \%$ & $-40,99 \%$ & $0,67 \%$ & $-2,22 \%$ & $-5,92 \%$ & $28,39 \%$ \\
\hline
\end{tabular}




\section{$\mathrm{J}$ priedas. Akcijų investiciniam patrauklumui (sprendimui dèl investavimo 2006-04-01-2007-04-01 laikotarpiui priimti) nustatyti taikytos kriteriju reikšmès}

J.1 lentelè. Akcijų investiciniam patrauklumui (sprendimui dèl investavimo 2006-04-01-2007-04-01 laikotarpiui priimti) nustatyti taikytos kriterijų reikšmès

Table J.1. Values of criterions used to evaluate stocks' investment attractiveness for 2006-04-01-2007-04-01 investment period

\begin{tabular}{|c|c|c|c|c|c|c|c|c|c|c|c|c|c|c|c|c|c|c|}
\hline \multirow{2}{*}{$\begin{array}{c}\text { Kriterijaus } \\
\mathrm{Nr} .\end{array}$} & \multicolumn{18}{|c|}{ Analizuojamos akcijos } \\
\hline & $\mathbf{A A}$ & BA & CAT & CVX & DD & GE & IBM & INTC & JNJ & KO & MCD & МММ & MRK & PFE & $\mathbf{T}$ & UTX & $\mathbf{V Z}$ & XOM \\
\hline 1 & $4,29 \%$ & $34,83 \%$ & $65,99 \%$ & $1,60 \%$ & $-12,78 \%$ & $0,50 \%$ & $-7,24 \%$ & $-14,68 \%$ & $-9,62 \%$ & $3,91 \%$ & $14,32 \%$ & $-8,83 \%$ & $15,09 \%$ & $-0,82 \%$ & $20,22 \%$ & $17,18 \%$ & $2,65 \%$ & $2,86 \%$ \\
\hline 2 & $11,41 \%$ & $4,56 \%$ & $20,13 \%$ & $27,62 \%$ & $1,75 \%$ & $-1,75 \%$ & $-5,36 \%$ & $13,50 \%$ & $6,67 \%$ & $5,19 \%$ & $973,45 \%$ & $5,80 \%$ & $-4,05 \%$ & $-2,32 \%$ & $7,53 \%$ & $14,10 \%$ & $5,37 \%$ & $24,37 \%$ \\
\hline 3 & $6,85 \%$ & $4,67 \%$ & $12,53 \%$ & $12,59 \%$ & $9,04 \%$ & $24,46 \%$ & $10,29 \%$ & $32,51 \%$ & $26,72 \%$ & $30,40 \%$ & $20,45 \%$ & $23,93 \%$ & $35,14 \%$ & $22,35 \%$ & $16,32 \%$ & $11,08 \%$ & $20,64 \%$ & $15,27 \%$ \\
\hline 4 & $-4,65 \%$ & $19,90 \%$ & $32,16 \%$ & $22,02 \%$ & $66,57 \%$ & $13,49 \%$ & $3,22 \%$ & $11,65 \%$ & $4,29 \%$ & $7,52 \%$ & $11,55 \%$ & $7,91 \%$ & $-2,67 \%$ & $-8,03 \%$ & $-5,85 \%$ & $13,24 \%$ & $1,59 \%$ & $35,88 \%$ \\
\hline 5 & $4,71 \%$ & $4,67 \%$ & $7,85 \%$ & $7,11 \%$ & $7,21 \%$ & $12,21 \%$ & $8,77 \%$ & $22,31 \%$ & $20,61 \%$ & \begin{tabular}{|l|l|}
$21,09 \%$ \\
\end{tabular} & $12,72 \%$ & $15,28 \%$ & $21,04 \%$ & $15,78 \%$ & $10,91 \%$ & $7,41 \%$ & $9,85 \%$ & $9,75 \%$ \\
\hline 6 & $14,47 \%$ & $7,84 \%$ & $-19,96 \%$ & $-18,65 \%$ & $-4,45 \%$ & $-16,88 \%$ & $14,71 \%$ & $-6,43 \%$ & $2,50 \%$ & $-3,84 \%$ & $-95,58 \%$ & $-1,36 \%$ & $-1,76 \%$ & $6,12 \%$ & $0,97 \%$ & $-5,80 \%$ & $-2,73 \%$ & $-13,22 \%$ \\
\hline 7 & $3,34 \%$ & $11,30 \%$ & $9,24 \%$ & $35,00 \%$ & $-6,68 \%$ & $-10,26 \%$ & $-3,14 \%$ & $0,35 \%$ & $8,83 \%$ & $-6,06 \%$ & $7,72 \%$ & $-0,97 \%$ & $5,36 \%$ & $-4,94 \%$ & $33,80 \%$ & $14,74 \%$ & $1,31 \%$ & $6,70 \%$ \\
\hline 8 & $7,81 \%$ & $-6,06 \%$ & $9,97 \%$ & $-5,46 \%$ & $9,03 \%$ & $9,49 \%$ & $-2,29 \%$ & $13,11 \%$ & $-1,98 \%$ & $11,98 \%$ & $896,50 \%$ & $6,83 \%$ & $-8,93 \%$ & $2,75 \%$ & $-19,64 \%$ & $-0,56 \%$ & $4,01 \%$ & $16,56 \%$ \\
\hline 9 & $-10,65 \%$ & $19,48 \%$ & $19,06 \%$ & $-20,08 \%$ & $20,20 \%$ & $-14,99 \%$ & $-13,77 \%$ & $17,73 \%$ & $3,02 \%$ & $-6,64 \%$ & $1,72 \%$ & $-4,53 \%$ & $-25,61 \%$ & $-29,01 \%$ & $-32,72 \%$ & $-3,06 \%$ & \begin{tabular}{|l|}
$-13,09 \%$ \\
\end{tabular} & $27,38 \%$ \\
\hline 10 & 1,52 & 4,43 & 4,58 & 1,01 & 2,73 & 5,16 & 2,19 & 0,34 & 0,53 & 0,80 & 0,98 & 1,03 & 1,50 & 0,79 & 1,66 & 1,70 & 3,24 & 3,21 \\
\hline 11 & 1,19 & 0,78 & 1,19 & 1,37 & 1,66 & 0,43 & 1,30 & 2,30 & 2,48 & 1,04 & 1,45 & 1,36 & 1,58 & 1,47 & 0,58 & 1,12 & 0,66 & 1,58 \\
\hline 12 & 0,07 & 0,14 & 0,09 & 0,16 & 0,06 & 0,10 & 0,11 & 0,10 & 0,06 & 0,06 & 0,11 & 0,07 & 0,11 & 0,08 & 0,17 & 0,08 & 0,24 & 0,13 \\
\hline 13 & 1,83 & 4,51 & 4,05 & 2,05 & 4,78 & 3,38 & 3,98 & 4,08 & 5,08 & 6,19 & 2,66 & 5,81 & 3,73 & 2,87 & 1,40 & 3,08 & 2,36 & 3,21 \\
\hline 14 & 19,80 & 19,39 & 11,98 & 9,12 & 20,33 & 22,58 & 16,63 & 17,03 & 18,49 & 20,80 & 15,49 & 18,35 & 14,44 & 23,27 & 15,96 & 16,07 & 12,64 & 9,89 \\
\hline 15 & $42,28 \%$ & $39,81 \%$ & $28,64 \%$ & $24,24 \%$ & $15,42 \%$ & $18,00 \%$ & $14,06 \%$ & $39,03 \%$ & $26,11 \%$ & $18,56 \%$ & $50,77 \%$ & $11,69 \%$ & $14,46 \%$ & $14,42 \%$ & $23,05 \%$ & $22,49 \%$ & $8,59 \%$ & $21,58 \%$ \\
\hline 16 & $2,30 \%$ & $23,41 \%$ & $0,72 \%$ & $36,21 \%$ & $15,05 \%$ & $-21,41 \%$ & $-3,39 \%$ & $14,21 \%$ & $-21,87 \%$ & $15,38 \%$ & $-32,75 \%$ & $-39,97 \%$ & $16,00 \%$ & $-9,17 \%$ & $8,61 \%$ & $-14,29 \%$ & $-2,27 \%$ & $-2,88 \%$ \\
\hline 17 & $1,78 \%$ & $1,26 \%$ & $1,26 \%$ & $2,95 \%$ & $3,36 \%$ & $2,72 \%$ & $0,97 \%$ & $1,70 \%$ & $2,25 \%$ & $2,74 \%$ & $1,94 \%$ & $2,01 \%$ & $4,42 \%$ & $3,20 \%$ & $4,97 \%$ & $1,40 \%$ & $4,90 \%$ & $1,89 \%$ \\
\hline 18 & $-7,13 \%$ & $30,28 \%$ & $45,86 \%$ & $-26,02 \%$ & $-14,53 \%$ & $2,24 \%$ & $-1,88 \%$ & $-28,19 \%$ & $-16,30 \%$ & $-1,28 \%$ & $-959,13 \%$ & $-14,63 \%$ & $19,15 \%$ & $1,50 \%$ & $12,69 \%$ & $3,08 \%$ & $-2,73 \%$ & $-21,51 \%$ \\
\hline
\end{tabular}




\section{K priedas. Akcijų investiciniam patrauklumui (sprendimui dèl investavimo 2007-04-01-2008-04-01 laikotarpiui priimti) nustatyti taikytos kriteriju reikšmès}

K.1 lentelè. Akcijų investiciniam patrauklumui (sprendimui dèl investavimo 2007-04-01-2008-04-01 laikotarpiui priimti) nustatyti taikytos kriterijų reikšmès

Table K.1. Values of criterions used to evaluate stocks' investment attractiveness for 2007-04-01-2008-04-01 investment period

\begin{tabular}{|c|c|c|c|c|c|c|c|c|c|c|c|c|c|c|c|c|c|c|}
\hline \multirow{2}{*}{$\begin{array}{c}\text { Kriterijaus } \\
\text { Nr. }\end{array}$} & \multicolumn{18}{|c|}{ Analizuojamos akcijos } \\
\hline & $\mathbf{A A}$ & BA & CAT & CVX & DD & GE & IBM & INTC & JNJ & KO & MCD & МММ & MRK & PFE & $\mathbf{T}$ & UTX & $\mathbf{V Z}$ & XOM \\
\hline 1 & $12,16 \%$ & $15,57 \%$ & $-7,64 \%$ & $32,29 \%$ & $18,34 \%$ & $4,82 \%$ & $16,22 \%$ & $0,96 \%$ & $3,97 \%$ & $19,16 \%$ & $32,21 \%$ & $2,99 \%$ & $31,97 \%$ & $4,81 \%$ & $53,21 \%$ & $13,09 \%$ & $19,44 \%$ & $27,08 \%$ \\
\hline 2 & $16,13 \%$ & $12,18 \%$ & $14,25 \%$ & $6,01 \%$ & $1,72 \%$ & $9,14 \%$ & $0,32 \%$ & $-8,88 \%$ & $5,56 \%$ & $4,29 \%$ & $5,52 \%$ & $8,27 \%$ & $2,86 \%$ & $-5,71 \%$ & $43,78 \%$ & $11,94 \%$ & $17,35 \%$ & $1,88 \%$ \\
\hline 3 & $12,46 \%$ & $5,23 \%$ & $14,32 \%$ & $15,00 \%$ & $8,62 \%$ & $27,43 \%$ & $13,64 \%$ & $18,38 \%$ & $26,22 \%$ & $27,41 \%$ & $21,44 \%$ & $25,07 \%$ & $29,17 \%$ & $26,32 \%$ & $20,15 \%$ & $11,26 \%$ & $11,70 \%$ & $16,93 \%$ \\
\hline 4 & $42,07 \%$ & $7,00 \%$ & $21,06 \%$ & $26,40 \%$ & $-3,73 \%$ & $15,73 \%$ & $5,39 \%$ & $-30,55 \%$ & $6,52 \%$ & $-1,53 \%$ & $9,60 \%$ & $13,00 \%$ & $-6,34 \%$ & $5,20 \%$ & $52,70 \%$ & $16,44 \%$ & $-21,69 \%$ & $13,24 \%$ \\
\hline 5 & $7,11 \%$ & $3,59 \%$ & $8,52 \%$ & $8,16 \%$ & $10,86 \%$ & $12,65 \%$ & $10,30 \%$ & $14,26 \%$ & $20,73 \%$ & $21,09 \%$ & $13,31 \%$ & $16,80 \%$ & $19,59 \%$ & $22,79 \%$ & $11,67 \%$ & $7,80 \%$ & $6,22 \%$ & $10,46 \%$ \\
\hline 6 & $-10,34 \%$ & $9,53 \%$ & $16,14 \%$ & $0,45 \%$ & $-3,57 \%$ & $-10,35 \%$ & $-5,03 \%$ & $22,20 \%$ & $-0,34 \%$ & $11,55 \%$ & $0,92 \%$ & $-9,98 \%$ & $10,31 \%$ & $-4,87 \%$ & $-8,65 \%$ & $-2,88 \%$ & $6,93 \%$ & $-2,45 \%$ \\
\hline 7 & $10,33 \%$ & $-13,77 \%$ & $8,09 \%$ & $5,40 \%$ & $-4,42 \%$ & $3,55 \%$ & $-2,38 \%$ & $0,12 \%$ & $21,59 \%$ & $1,80 \%$ & $-3,23 \%$ & $3,80 \%$ & $-0,62 \%$ & $-2,32 \%$ & $85,83 \%$ & $2,63 \%$ & $12,29 \%$ & $5,13 \%$ \\
\hline 8 & $5,26 \%$ & $30,09 \%$ & $5,70 \%$ & $0,58 \%$ & $6,43 \%$ & $5,40 \%$ & $2,77 \%$ & $-9,00 \%$ & $-13,18 \%$ & $2,44 \%$ & $9,05 \%$ & $4,30 \%$ & $3,51 \%$ & $-3,47 \%$ & $-22,63 \%$ & $9,06 \%$ & $4,50 \%$ & $-3,09 \%$ \\
\hline 9 & $74,24 \%$ & $22,19 \%$ & $29,17 \%$ & $-0,34 \%$ & $70,38 \%$ & $26,23 \%$ & $22,08 \%$ & $-40,34 \%$ & $-4,18 \%$ & $1,24 \%$ & $30,55 \%$ & $22,83 \%$ & $-5,05 \%$ & $133,85 \%$ & $-14,08 \%$ & $3,44 \%$ & $-26,64 \%$ & $3,46 \%$ \\
\hline 10 & 1,54 & 9,93 & 6,42 & 0,92 & 2,37 & 5,21 & 2,62 & 0,32 & 0,79 & 0,77 & 0,88 & 1,14 & 1,54 & 0,61 & 1,34 & 1,73 & 2,89 & 3,29 \\
\hline 11 & 1,26 & 0,77 & 1,20 & 1,28 & 1,62 & 1,99 & 1,11 & 2,15 & 1,20 & 0,95 & 1,21 & 1,22 & 1,20 & 2,20 & 0,63 & 1,24 & 0,70 & 1,55 \\
\hline 12 & 0,10 & 0,12 & 0,13 & 0,18 & 0,09 & 0,09 & 0,12 & 0,09 & 0,08 & 0,06 & 0,10 & 0,07 & 0,08 & 0,10 & 0,09 & 0,08 & 0,24 & 0,13 \\
\hline 13 & 1,80 & 13,31 & 6,47 & 1,98 & 4,29 & 3,14 & 4,39 & 3,13 & 4,58 & 6,01 & 2,86 & 5,67 & 4,73 & 2,57 & 1,58 & 3,55 & 2,04 & 3,29 \\
\hline 14 & 11,65 & 27,95 & 12,53 & 7,96 & 12,55 & 16,95 & 13,19 & 22,83 & 16,29 & 20,02 & 12,51 & 14,67 & 18,74 & 9,46 & 24,82 & 16,45 & 15,99 & 9,48 \\
\hline 15 & $42,33 \%$ & $37,27 \%$ & $33,07 \%$ & $25,13 \%$ & $15,36 \%$ & $17,35 \%$ & $15,28 \%$ & $37,90 \%$ & $17,44 \%$ & $19,16 \%$ & $50,44 \%$ & $11,83 \%$ & $19,99 \%$ & $14,52 \%$ & $30,51 \%$ & $21,84 \%$ & $12,25 \%$ & $22,22 \%$ \\
\hline 16 & $46,82 \%$ & $0,93 \%$ & $15,39 \%$ & $14,66 \%$ & $9,94 \%$ & $29,77 \%$ & $3,44 \%$ & $-6,25 \%$ & $28,83 \%$ & $-2,84 \%$ & $25,96 \%$ & $10,63 \%$ & $69,76 \%$ & $53,50 \%$ & $-12,10 \%$ & $-11,97 \%$ & $-6,51 \%$ & $-0,87 \%$ \\
\hline 17 & $1,89 \%$ & $1,34 \%$ & $1,58 \%$ & $2,67 \%$ & $3,01 \%$ & $2,88 \%$ & $1,17 \%$ & $1,92 \%$ & $2,34 \%$ & $2,43 \%$ & $2,07 \%$ & $2,25 \%$ & $2,95 \%$ & $3,82 \%$ & $3,50 \%$ & $1,58 \%$ & $7,68 \%$ & $1,61 \%$ \\
\hline 18 & $-3,97 \%$ & $3,39 \%$ & $-21,89 \%$ & $26,28 \%$ & $16,62 \%$ & $-4,32 \%$ & $15,90 \%$ & $9,85 \%$ & $-1,60 \%$ & $14,88 \%$ & $26,69 \%$ & $-5,28 \%$ & $29,10 \%$ & $10,52 \%$ & $9,44 \%$ & $1,16 \%$ & $2,09 \%$ & $25,20 \%$ \\
\hline
\end{tabular}




\section{L priedas. Akciju investiciniam patrauklumui (sprendimui dèl investavimo 2008-04-01-2009-04-01 laikotarpiui priimti) nustatyti taikytos kriteriju reikšmès}

L.1 lentelè. Akcijų investiciniam patrauklumui (sprendimui dèl investavimo 2008-04-01-2009-04-01 laikotarpiui priimti) nustatyti taikytos kriterijų reikšmès

Table L.1. Values of criterions used to evaluate stocks' investment attractiveness for 2008-04-01-2009-04-01 investment period

\begin{tabular}{|c|c|c|c|c|c|c|c|c|c|c|c|c|c|c|c|c|c|c|}
\hline \multirow{2}{*}{$\begin{array}{c}\text { Kriterijaus } \\
\mathrm{Nr} .\end{array}$} & \multicolumn{18}{|c|}{ Analizuojamos akcijos } \\
\hline & $\mathbf{A A}$ & BA & CAT & CVX & DD & GE & IBM & INTC & JNJ & KO & MCD & MMM & MRK & PFE & $T$ & UTX & $\mathbf{V Z}$ & XOM \\
\hline 1 & $9,78 \%$ & $-13,24 \%$ & $22,10 \%$ & $19,22 \%$ & $0,54 \%$ & $12,38 \%$ & $24,17 \%$ & $17,22 \%$ & $12,50 \%$ & $29,79 \%$ & $31,21 \%$ & $9,11 \%$ & $-12,23 \%$ & $-11,40 \%$ & $3,70 \%$ & $11,95 \%$ & $4,42 \%$ & $16,16 \%$ \\
\hline 2 & $1,22 \%$ & $7,90 \%$ & $8,29 \%$ & $5,13 \%$ & $1,38 \%$ & $5,72 \%$ & $8,06 \%$ & $8,34 \%$ & $14,59 \%$ & $19,80 \%$ & $5,56 \%$ & $6,72 \%$ & $6,89 \%$ & $0,10 \%$ & $88,60 \%$ & $14,49 \%$ & $6,05 \%$ & $7,13 \%$ \\
\hline 3 & $10,12 \%$ & $8,94 \%$ & $13,68 \%$ & $13,48 \%$ & $9,95 \%$ & $29,03 \%$ & $14,25 \%$ & $23,94 \%$ & $23,10 \%$ & $28,26 \%$ & $17,87 \%$ & $25,86 \%$ & $17,18 \%$ & $18,62 \%$ & $17,74 \%$ & $11,34 \%$ & $17,47 \%$ & $16,45 \%$ \\
\hline 4 & $24,46 \%$ & $51,21 \%$ & $5,28 \%$ & $2,78 \%$ & $6,09 \%$ & $14,32 \%$ & $9,26 \%$ & $16,18 \%$ & $-2,79 \%$ & $22,61 \%$ & $-10,65 \%$ & $8,26 \%$ & $-35,21 \%$ & $-18,59 \%$ & $91,42 \%$ & $14,99 \%$ & $22,32 \%$ & $4,59 \%$ \\
\hline 5 & $8,36 \%$ & $6,11 \%$ & $7,88 \%$ & $8,46 \%$ & $10,17 \%$ & $13,01 \%$ & $10,55 \%$ & $18,20 \%$ & $17,31 \%$ & $20,73 \%$ & $10,25 \%$ & $16,74 \%$ & $13,54 \%$ & $16,96 \%$ & $10,05 \%$ & $7,71 \%$ & $5,90 \%$ & $10,04 \%$ \\
\hline 6 & $2,11 \%$ & $-16,32 \%$ & $-3,42 \%$ & $9,26 \%$ & $-17,12 \%$ & $5,36 \%$ & $-1,33 \%$ & $-13,71 \%$ & $5,53 \%$ & $-6,77 \%$ & $32,52 \%$ & $-7,30 \%$ & $20,86 \%$ & $0,60 \%$ & $19,46 \%$ & $-2,06 \%$ & $-12,86 \%$ & $-2,30 \%$ \\
\hline 7 & $4,36 \%$ & $13,90 \%$ & $10,32 \%$ & $12,18 \%$ & $7,39 \%$ & $14,07 \%$ & $16,66 \%$ & $15,05 \%$ & $13,87 \%$ & $44,43 \%$ & $1,27 \%$ & $15,97 \%$ & $8,48 \%$ & $0,37 \%$ & $1,85 \%$ & $15,78 \%$ & $-0,97 \%$ & $10,53 \%$ \\
\hline 8 & $-3,01 \%$ & $-5,27 \%$ & $-1,84 \%$ & $-6,29 \%$ & $-5,60 \%$ & $-7,32 \%$ & $-7,37 \%$ & $-5,83 \%$ & $0,63 \%$ & $-17,05 \%$ & $4,23 \%$ & $-7,98 \%$ & $-1,47 \%$ & $-0,27 \%$ & $85,17 \%$ & $-1,12 \%$ & $7,09 \%$ & $-3,08 \%$ \\
\hline 9 & $3,94 \%$ & $110,82 \%$ & $-2,86 \%$ & $-1,72 \%$ & $-15,39 \%$ & $3,72 \%$ & $18,72 \%$ & $27,03 \%$ & $-10,57 \%$ & $1,33 \%$ & $-32,49 \%$ & $-1,60 \%$ & $-26,50 \%$ & $-57,70 \%$ & $19,70 \%$ & $0,35 \%$ & $-20,76 \%$ & $-1,80 \%$ \\
\hline 10 & 1,42 & 5,55 & 5,32 & 0,93 & 2,06 & 5,88 & 3,23 & 0,30 & 0,87 & 0,99 & 0,92 & 1,10 & 1,66 & 0,77 & 1,39 & 1,56 & 2,70 & 3,68 \\
\hline 11 & 1,13 & 0,86 & 1,15 & 1,17 & 1,54 & 1,99 & 1,20 & 2,79 & 1,51 & 0,92 & 0,80 & 1,83 & 1,23 & 2,15 & 0,63 & 1,26 & 0,76 & 1,47 \\
\hline 12 & 0,10 & 0,13 & 0,18 & 0,14 & 0,10 & 0,12 & 0,11 & 0,09 & 0,08 & 0,06 & 0,08 & 0,07 & 0,06 & 0,08 & 0,14 & 0,08 & 0,22 & 0,12 \\
\hline 13 & 1,89 & 8,07 & 5,10 & 2,24 & 4,07 & 3,27 & 5,15 & 3,19 & 4,19 & 5,73 & 3,89 & 5,07 & 6,05 & 2,63 & 2,06 & 3,29 & 2,34 & 3,68 \\
\hline 14 & 11,79 & 17,84 & 12,81 & 9,22 & 14,88 & 17,00 & 14,07 & 19,52 & 17,17 & 20,85 & 24,75 & 14,53 & 33,56 & 20,98 & 19,86 & 16,67 & 21,48 & 11,03 \\
\hline 15 & $32,41 \%$ & $26,05 \%$ & $28,33 \%$ & $14,39 \%$ & $12,81 \%$ & $7,66 \%$ & $12,09 \%$ & $30,53 \%$ & $17,02 \%$ & $17,16 \%$ & $36,01 \%$ & $11,31 \%$ & $20,80 \%$ & $13,31 \%$ & $18,73 \%$ & $13,86 \%$ & $6,91 \%$ & $15,27 \%$ \\
\hline 16 & $83,95 \%$ & $43,06 \%$ & $10,31 \%$ & $8,95 \%$ & $16,57 \%$ & $35,93 \%$ & $14,68 \%$ & $4,44 \%$ & $4,66 \%$ & $14,18 \%$ & $21,02 \%$ & $4,06 \%$ & $-19,69 \%$ & $6,14 \%$ & $47,55 \%$ & $-8,73 \%$ & $41,96 \%$ & $63,20 \%$ \\
\hline 17 & $1,96 \%$ & $1,71 \%$ & $1,69 \%$ & $2,41 \%$ & $3,19 \%$ & $3,61 \%$ & $1,33 \%$ & $2,10 \%$ & $2,47 \%$ & $2,38 \%$ & $3,15 \%$ & $2,52 \%$ & $4,00 \%$ & $5,92 \%$ & $3,78 \%$ & $1,69 \%$ & $4,78 \%$ & $1,50 \%$ \\
\hline 18 & $8,56 \%$ & $-21,14 \%$ & $13,81 \%$ & $14,09 \%$ & $-0,84 \%$ & $6,65 \%$ & $16,11 \%$ & $8,88 \%$ & $-2,09 \%$ & $9,98 \%$ & $25,65 \%$ & $2,39 \%$ & $-19,12 \%$ & $-11,50 \%$ & $-84,90 \%$ & $-2,54 \%$ & $-1,63 \%$ & $9,04 \%$ \\
\hline
\end{tabular}




\section{M priedas. Akcijų investiciniam patrauklumui (sprendimui dèl investavimo 2009-04-01-2010-04-01 laikotarpiui priimti) nustatyti taikytos kriteriju reikšmès}

M.1 lentelè. Akcijų investiciniam patrauklumui (sprendimui dèl investavimo 2009-04-01-2010-04-01 laikotarpiui priimti) nustatyti taikytos kriterijų reikšmès

Table M.1. Values of criterions used to evaluate stocks' investment attractiveness for 2009-04-01-2010-04-01 investment period

\begin{tabular}{|c|c|c|c|c|c|c|c|c|c|c|c|c|c|c|c|c|c|c|}
\hline \multirow{2}{*}{$\begin{array}{c}\text { Kriterijaus } \\
\text { Nr. }\end{array}$} & \multicolumn{18}{|c|}{ Analizuojamos akcijos } \\
\hline & $\mathbf{A A}$ & BA & CAT & CVX & DD & GE & IBM & INTC & JNJ & KO & MCD & МMM & MRK & PFE & $T$ & UTX & $\mathbf{V Z}$ & XOM \\
\hline 1 & $-78,23 \%$ & $-51,96 \%$ & $-62,60 \%$ & $-18,69 \%$ & $-48,45 \%$ & $-71,56 \%$ & $-14,60 \%$ & $-29,44 \%$ & $-17,03 \%$ & $-24,56 \%$ & $0,08 \%$ & $-35,66 \%$ & $-25,82 \%$ & $-29,73 \%$ & $-30,77 \%$ & $-36,85 \%$ & $-12,76 \%$ & $-18,80 \%$ \\
\hline 2 & $-12,52 \%$ & $-8,25 \%$ & $14,15 \%$ & $23,59 \%$ & $3,91 \%$ & $5,66 \%$ & $4,90 \%$ & $-1,93 \%$ & $4,34 \%$ & $10,67 \%$ & $3,20 \%$ & $3,31 \%$ & $10,95 \%$ & $-0,25 \%$ & $4,29 \%$ & $7,16 \%$ & $4,15 \%$ & $18,00 \%$ \\
\hline 3 & $4,59 \%$ & $6,46 \%$ & $13,34 \%$ & $14,79 \%$ & $5,50 \%$ & $24,85 \%$ & $12,89 \%$ & $25,40 \%$ & $25,65 \%$ & $24,75 \%$ & $21,55 \%$ & $21,07 \%$ & $34,57 \%$ & $26,65 \%$ & $19,26 \%$ & $11,91 \%$ & $18,30 \%$ & $16,21 \%$ \\
\hline 4 & $-61,90 \%$ & $-26,95 \%$ & $-3,55 \%$ & $27,90 \%$ & $-26,78 \%$ & $-6,30 \%$ & $12,51 \%$ & $-12,07 \%$ & $23,47 \%$ & $-4,00 \%$ & $51,73 \%$ & $-12,53 \%$ & $103,66 \%$ & $-0,06 \%$ & $-0,18 \%$ & $8,61 \%$ & $1,71 \%$ & $14,05 \%$ \\
\hline 5 & $0,85 \%$ & $4,36 \%$ & $6,93 \%$ & $8,77 \%$ & $6,57 \%$ & $9,91 \%$ & $11,90 \%$ & $14,08 \%$ & $20,31 \%$ & $18,18 \%$ & $18,34 \%$ & $13,69 \%$ & $32,74 \%$ & $16,62 \%$ & $10,37 \%$ & $7,99 \%$ & $6,60 \%$ & $9,47 \%$ \\
\hline 6 & $17,68 \%$ & $2,95 \%$ & $-11,73 \%$ & $-19,70 \%$ & $-1,22 \%$ & $2,80 \%$ & $9,58 \%$ & $4,60 \%$ & $-5,03 \%$ & $9,52 \%$ & $-8,28 \%$ & $15,50 \%$ & $-33,92 \%$ & $-1,41 \%$ & $-6,89 \%$ & \begin{tabular}{|l|}
$-0,49 \%$ \\
\end{tabular} & $-1,71 \%$ & $-10,38 \%$ \\
\hline 7 & $-3,92 \%$ & $-8,83 \%$ & $20,76 \%$ & $8,32 \%$ & $6,09 \%$ & $0,31 \%$ & $-9,06 \%$ & $-8,86 \%$ & $4,78 \%$ & $-6,36 \%$ & $-3,16 \%$ & $3,48 \%$ & $-2,38 \%$ & $-3,57 \%$ & $-3,77 \%$ & $3,46 \%$ & $8,23 \%$ & $-5,80 \%$ \\
\hline 8 & $-8,95 \%$ & $0,63 \%$ & $-5,47 \%$ & $14,10 \%$ & $-2,05 \%$ & $5,34 \%$ & $15,35 \%$ & $7,60 \%$ & $-0,42 \%$ & $18,18 \%$ & $6,58 \%$ & $-0,17 \%$ & $13,65 \%$ & $3,45 \%$ & $8,37 \%$ & $3,57 \%$ & $-3,77 \%$ & $25,26 \%$ \\
\hline 9 & $-103,19 \%$ & $16,91 \%$ & $5,74 \%$ & $14,19 \%$ & $-24,47 \%$ & $-19,22 \%$ & $60,76 \%$ & $-26,38 \%$ & $17,85 \%$ & $-11,01 \%$ & $92,62 \%$ & $-15,30 \%$ & $130,37 \%$ & $10,71 \%$ & $17,46 \%$ & $15,25 \%$ & $25,11 \%$ & $11,76 \%$ \\
\hline 10 & 2,22 & 10,38 & 10,14 & 0,86 & 4,08 & 6,62 & 7,13 & 0,30 & 1,00 & 0,98 & 1,13 & 1,59 & 1,52 & 0,93 & 1,75 & 2,55 & 3,85 & 3,64 \\
\hline 11 & 1,12 & 0,84 & 1,21 & 1,14 & 1,58 & 2,02 & 1,15 & 2,54 & 1,65 & 0,94 & 1,39 & 1,64 & 1,35 & 1,59 & 0,53 & 1,24 & 1,01 & 1,47 \\
\hline 12 & 0,05 & $-0,01$ & 0,12 & 0,17 & 0,08 & 0,16 & 0,13 & 0,10 & 0,08 & 0,06 & 0,09 & 0,09 & 0,08 & 0,14 & 0,17 & 0,10 & 0,26 & 0,15 \\
\hline 13 & 1,96 & 11,23 & 6,42 & 1,96 & 5,45 & 2,82 & 10,94 & 2,84 & 4,22 & 6,08 & 4,83 & 5,02 & 4,17 & 2,27 & 2,03 & 3,79 & 2,48 & 3,64 \\
\hline 14 & 21,51 & 18,08 & 10,97 & 7,11 & 18,78 & 17,04 & 11,95 & 20,99 & 13,86 & 21,44 & 15,00 & 14,34 & 10,01 & 16,08 & 15,21 & 12,86 & 16,11 & 9,10 \\
\hline 15 & $33,79 \%$ & $35,51 \%$ & $42,08 \%$ & $21,02 \%$ & $25,59 \%$ & $32,86 \%$ & $14,53 \%$ & $15,96 \%$ & $18,17 \%$ & $20,53 \%$ & $12,54 \%$ & $16,50 \%$ & $22,93 \%$ & $13,30 \%$ & $27,43 \%$ & $20,95 \%$ & $10,33 \%$ & $22,83 \%$ \\
\hline 16 & $68,87 \%$ & $34,29 \%$ & $38,14 \%$ & $42,76 \%$ & $34,87 \%$ & $56,32 \%$ & $27,02 \%$ & $3,65 \%$ & $46,46 \%$ & $36,47 \%$ & $1,44 \%$ & $6,72 \%$ & $11,69 \%$ & $20,01 \%$ & $62,55 \%$ & $4,89 \%$ & $12,73 \%$ & $9,02 \%$ \\
\hline 17 & $7,50 \%$ & $4,04 \%$ & $4,55 \%$ & $3,93 \%$ & $5,88 \%$ & $9,80 \%$ & $1,94 \%$ & $3,55 \%$ & $3,51 \%$ & $3,60 \%$ & $3,28 \%$ & $3,49 \%$ & $6,27 \%$ & $9,58 \%$ & $6,28 \%$ & $2,89 \%$ & $5,87 \%$ & $2,40 \%$ \\
\hline 18 & $-65,71 \%$ & $-43,70 \%$ & $-76,75 \%$ & $-42,28 \%$ & $-52,36 \%$ & $\mid-77,22 \%$ & $-19,50 \%$ & $-27,51 \%$ & $-21,37 \%$ & $-35,24 \%$ & $-3,12 \%$ & $-38,97 \%$ & $-36,77 \%$ & $-29,48 \%$ & $-35,06 \%$ & $-44,00 \%$ & $-16,91 \%$ & $-36,80 \%$ \\
\hline
\end{tabular}



2010-04-01-2011-04-01 laikotarpiui priimti) nustatyti taikytos kriteriju reikšmès

N.1 lentelè. Akcijų investiciniam patrauklumui (sprendimui dèl investavimo 2010-04-01-2011-04-01 laikotarpiui priimti) nustatyti taikytos kriterijų reikšmès

Table N.1. Values of criterions used to evaluate stocks' investment attractiveness for 2010-04-01-2011-04-01 investment period

\begin{tabular}{|c|c|c|c|c|c|c|c|c|c|c|c|c|c|c|c|c|c|c|}
\hline \multirow{2}{*}{$\begin{array}{c}\text { Kriterijaus } \\
\text { Nr. }\end{array}$} & \multicolumn{18}{|c|}{ Analizuojamos akcijos } \\
\hline & AA & BA & CAT & CVX & DD & GE & IBM & INTC & JNJ & KO & MCD & MMM & MRK & PFE & $\mathrm{T}$ & UTX & $\mathbf{V Z}$ & XOM \\
\hline 1 & $95,29 \%$ & $113,29 \%$ & $129,58 \%$ & $16,61 \%$ & $70,33 \%$ & $85,19 \%$ & $33,88 \%$ & $53,67 \%$ & $28,09 \%$ & $27,25 \%$ & $26,59 \%$ & $70,40 \%$ & $46,37 \%$ & $27,10 \%$ & $7,26 \%$ & $73,41 \%$ & $6,36 \%$ & $0,06 \%$ \\
\hline 2 & $-31,45 \%$ & $12,10 \%$ & $-36,87 \%$ & $-37,13 \%$ & $-14,48 \%$ & $-14,10 \%$ & $-7,59 \%$ & $-6,54 \%$ & $-2,90 \%$ & $-2,97 \%$ & $-3,32 \%$ & $-8,51 \%$ & $2,16 \%$ & $3,54 \%$ & $-0,81 \%$ & $-9,82 \%$ & $10,74 \%$ & $-34,94 \%$ \\
\hline 3 & $-6,35 \%$ & $2,74 \%$ & $10,97 \%$ & $8,34 \%$ & $9,45 \%$ & $18,57 \%$ & $17,77 \%$ & $16,25 \%$ & $25,33 \%$ & $29,88 \%$ & $29,52 \%$ & $20,98 \%$ & $17,62 \%$ & $23,73 \%$ & $18,07 \%$ & $11,28 \%$ & $13,59 \%$ & $8,45 \%$ \\
\hline 4 & $-89,95 \%$ & $-36,55 \%$ & $-44,04 \%$ & $-41,72 \%$ & $-3,09 \%$ & $-30,45 \%$ & $3,02 \%$ & $-12,35 \%$ & $-6,04 \%$ & $14,82 \%$ & $3,68 \%$ & $-7,17 \%$ & $55,69 \%$ & $9,64 \%$ & \begin{tabular}{|l|}
$-3,24 \%$ \\
\end{tabular} & $-14,10 \%$ & $-6,27 \%$ & $-50,57 \%$ \\
\hline 5 & $-5,01 \%$ & $1,96 \%$ & $2,76 \%$ & $6,11 \%$ & $6,72 \%$ & $7,29 \%$ & $14,02 \%$ & $12,44 \%$ & $19,82 \%$ & $22,02 \%$ & $20,01 \%$ & $13,81 \%$ & $47,04 \%$ & $17,26 \%$ & $10,19 \%$ & $7,24 \%$ & $9,61 \%$ & $6,21 \%$ \\
\hline 6 & $13,28 \%$ & $23,54 \%$ & $43,62 \%$ & $55,78 \%$ & $2,43 \%$ & $11,93 \%$ & \begin{tabular}{|l|}
$-8,95 \%$ \\
\end{tabular} & $26,91 \%$ & $-0,84 \%$ & \begin{tabular}{|l|}
$-11,85 \%$ \\
\end{tabular} & $-28,81 \%$ & $3,64 \%$ & $35,70 \%$ & $1,13 \%$ & $1,10 \%$ & $-0,79 \%$ & $8,83 \%$ & $-2,46 \%$ \\
\hline 7 & $3,19 \%$ & $15,38 \%$ & $-11,42 \%$ & $2,14 \%$ & $5,47 \%$ & $-2,00 \%$ & $-0,46 \%$ & $4,69 \%$ & $12,46 \%$ & $20,11 \%$ & $6,18 \%$ & $6,65 \%$ & $137,48 \%$ & $91,59 \%$ & $1,32 \%$ & $-1,26 \%$ & $12,31 \%$ & $2,31 \%$ \\
\hline 8 & $-33,57 \%$ & $-2,84 \%$ & $-28,73 \%$ & $-38,45 \%$ & $-18,91 \%$ & $-12,35 \%$ & $-7,17 \%$ & $-10,73 \%$ & $-13,66 \%$ & $-19,22 \%$ & $-8,95 \%$ & $-14,22 \%$ & $-56,98 \%$ & $-45,96 \%$ & $-2,11 \%$ & $-8,67 \%$ & $-1,39 \%$ & $-36,41 \%$ \\
\hline 9 & $-1685,62 \%$ & $350,33 \%$ & $-74,62 \%$ & $-59,84 \%$ & $12,04 \%$ & $-38,60 \%$ & $26,51 \%$ & $-16,31 \%$ & $-12,65 \%$ & $9,45 \%$ & $10,38 \%$ & $-11,92 \%$ & $-21,60 \%$ & $-11,40 \%$ & $4,06 \%$ & $-15,41 \%$ & $-37,12 \%$ & $-55,23 \%$ \\
\hline 10 & 2,10 & 28,16 & 5,87 & 0,79 & 4,29 & 5,67 & 3,82 & 0,27 & 0,87 & 0,96 & 1,15 & 1,13 & 0,90 & 1,37 & 1,64 & 1,78 & 4,46 & 3,12 \\
\hline 11 & 1,30 & 1,07 & 1,39 & 1,42 & 1,84 & 2,76 & 1,36 & 2,79 & 1,82 & 1,28 & 1,14 & 2,20 & 1,80 & 1,66 & 0,66 & 1,29 & 0,78 & 1,06 \\
\hline 12 & 0,18 & 0,19 & 0,32 & 0,14 & 0,24 & 0,17 & 0,18 & 0,15 & 0,11 & 0,08 & 0,09 & 0,14 & 0,04 & 0,14 & 0,23 & 0,12 & 0,36 & 0,08 \\
\hline 13 & 0,60 & 13,59 & 2,25 & 1,49 & 2,84 & 1,21 & 5,22 & 1,83 & 2,98 & 3,96 & 4,32 & 2,81 & 1,44 & 1,33 & 1,45 & 2,14 & 2,13 & 3,12 \\
\hline 14 & 28,03 & 22,08 & 21,96 & 13,02 & 11,36 & 13,27 & 8,79 & 17,50 & 12,27 & 14,39 & 13,31 & 11,26 & 6,61 & 13,84 & 11,76 & 11,20 & 24,29 & 17,91 \\
\hline 15 & $54,93 \%$ & $55,18 \%$ & $65,21 \%$ & $17,43 \%$ & $39,08 \%$ & $49,72 \%$ & $18,50 \%$ & $28,66 \%$ & $16,00 \%$ & $19,99 \%$ & $12,19 \%$ & $34,95 \%$ & $26,84 \%$ & $18,72 \%$ & $27,13 \%$ & $34,97 \%$ & $10,26 \%$ & $15,53 \%$ \\
\hline 16 & $51,70 \%$ & $-10,73 \%$ & $48,63 \%$ & $-3,69 \%$ & $39,25 \%$ & $153,45 \%$ & $17,68 \%$ & $1,90 \%$ & $23,12 \%$ & $37,68 \%$ & $32,81 \%$ & $23,97 \%$ & $48,80 \%$ & $23,16 \%$ & $23,60 \%$ & $28,55 \%$ & $17,21 \%$ & $18,07 \%$ \\
\hline 17 & $0,89 \%$ & $2,32 \%$ & $2,47 \%$ & $3,30 \%$ & $4,12 \%$ & $2,12 \%$ & $1,71 \%$ & $2,53 \%$ & $3,05 \%$ & $3,12 \%$ & $2,97 \%$ & $2,32 \%$ & $4,34 \%$ & $3,95 \%$ & $6,33 \%$ & $2,11 \%$ & $6,47 \%$ & $2,48 \%$ \\
\hline 18 & $126,74 \%$ & $101,20 \%$ & $166,45 \%$ & $53,74 \%$ & $84,81 \%$ & $99,29 \%$ & $41,47 \%$ & $60,22 \%$ & $30,99 \%$ & $30,22 \%$ & $29,91 \%$ & \begin{tabular}{|l|}
$78,91 \%$ \\
\end{tabular} & $44,21 \%$ & $23,56 \%$ & $8,07 \%$ & $83,22 \%$ & $-4,39 \%$ & $35,00 \%$ \\
\hline
\end{tabular}




\section{O priedas. Akcijų investiciniam patrauklumui (sprendimui dèl investavimo 2011-04-01-2012-04-01 laikotarpiui priimti) nustatyti taikytos kriteriju reikšmès}

O.1 lentelè. Akcijų investiciniam patrauklumui (sprendimui dèl investavimo 2011-04-01-2012-04-01 laikotarpiui priimti) nustatyti taikytos kriterijų reikšmès

Table O.1. Values of criterions used to evaluate stocks' investment attractiveness for 2011-04-01-2012-04-01 investment period

\begin{tabular}{|c|c|c|c|c|c|c|c|c|c|c|c|c|c|c|c|c|c|c|}
\hline \multirow{2}{*}{$\begin{array}{c}\text { Kriterijaus } \\
\mathrm{Nr} .\end{array}$} & \multicolumn{18}{|c|}{ Analizuojamos akcijos } \\
\hline & $\mathbf{A A}$ & BA & CAT & CVX & DD & GE & IBM & INTC & JNJ & KO & MCD & МMM & MRK & PFE & $T$ & UTX & $\mathbf{V Z}$ & XOM \\
\hline 1 & $19,92 \%$ & $3,83 \%$ & $80,91 \%$ & $46,21 \%$ & $51,03 \%$ & $14,17 \%$ & $30,47 \%$ & $-9,14 \%$ & $-6,22 \%$ & $25,27 \%$ & $16,07 \%$ & $13,85 \%$ & $-8,39 \%$ & $24,44 \%$ & $24,81 \%$ & $17,72 \%$ & $30,76 \%$ & $28,47 \%$ \\
\hline 2 & $13,94 \%$ & $-5,81 \%$ & $31,45 \%$ & $19,40 \%$ & $25,35 \%$ & $-4,19 \%$ & $4,29 \%$ & $24,17 \%$ & $-0,50 \%$ & $13,33 \%$ & $5,85 \%$ & $15,31 \%$ & $67,66 \%$ & $35,59 \%$ & $1,02 \%$ & $2,66 \%$ & $-1,15 \%$ & $23,38 \%$ \\
\hline 3 & $5,07 \%$ & $7,31 \%$ & $14,51 \%$ & $12,38 \%$ & $9,46 \%$ & $45,47 \%$ & $18,17 \%$ & $36,80 \%$ & $27,01 \%$ & $27,88 \%$ & $30,22 \%$ & $22,34 \%$ & $6,61 \%$ & $21,07 \%$ & $16,36 \%$ & $13,33 \%$ & $14,31 \%$ & $10,47 \%$ \\
\hline 4 & $963,06 \%$ & $80,53 \%$ & $64,40 \%$ & $47,30 \%$ & $38,73 \%$ & $0,35 \%$ & $5,91 \%$ & $91,84 \%$ & $7,17 \%$ & $56,50 \%$ & $6,72 \%$ & $17,45 \%$ & $-47,09 \%$ & $27,44 \%$ & $-3,54 \%$ & $12,75 \%$ & $-2,29 \%$ & $43,06 \%$ \\
\hline 5 & $1,90 \%$ & $5,15 \%$ & $6,34 \%$ & $9,28 \%$ & $9,26 \%$ & $8,76 \%$ & $14,82 \%$ & $26,28 \%$ & $21,65 \%$ & $33,63 \%$ & $20,55 \%$ & $15,32 \%$ & $1,87 \%$ & $12,24 \%$ & $15,61 \%$ & $8,05 \%$ & $2,39 \%$ & $7,95 \%$ \\
\hline 6 & $-10,29 \%$ & $-12,58 \%$ & $-12,97 \%$ & $-6,90 \%$ & $15,41 \%$ & $-6,67 \%$ & $-1,34 \%$ & $-27,19 \%$ & $-4,24 \%$ & $4,58 \%$ & $4,52 \%$ & $-5,22 \%$ & $17,92 \%$ & $-4,48 \%$ & $1,52 \%$ & $-6,03 \%$ & $-2,32 \%$ & $-9,65 \%$ \\
\hline 7 & $2,13 \%$ & $10,51 \%$ & $6,63 \%$ & $12,24 \%$ & $5,81 \%$ & $-3,91 \%$ & $4,06 \%$ & $19,00 \%$ & $8,69 \%$ & $49,83 \%$ & $5,82 \%$ & $10,68 \%$ & $-5,63 \%$ & $-8,42 \%$ & $-0,10 \%$ & $4,90 \%$ & $-3,19 \%$ & $29,65 \%$ \\
\hline 8 & $11,56 \%$ & $-14,77 \%$ & $23,28 \%$ & $6,37 \%$ & $18,47 \%$ & $-0,29 \%$ & $0,22 \%$ & $4,34 \%$ & $-8,46 \%$ & $-24,36 \%$ & $0,02 \%$ & $4,19 \%$ & $77,66 \%$ & $48,07 \%$ & $1,12 \%$ & $-2,13 \%$ & $2,10 \%$ & $-4,84 \%$ \\
\hline 9 & $120,50 \%$ & $-56,69 \%$ & $128,72 \%$ & $64,51 \%$ & $49,73 \%$ & $-1,05 \%$ & $-12,73 \%$ & $132,49 \%$ & $-5,62 \%$ & $40,49 \%$ & $4,05 \%$ & $2,14 \%$ & $-95,43 \%$ & $-20,66 \%$ & $47,03 \%$ & $-0,95 \%$ & $-27,40 \%$ & $37,20 \%$ \\
\hline 10 & 1,89 & 23,79 & 4,91 & 0,76 & 3,36 & 5,32 & 3,92 & 0,28 & 0,82 & 1,35 & 1,18 & 0,93 & 0,95 & 1,22 & 1,40 & 1,74 & 4,70 & 2,26 \\
\hline 11 & 1,31 & 1,15 & 1,44 & 1,68 & 2,03 & 3,01 & 1,19 & 3,39 & 2,05 & 1,17 & 1,49 & 2,01 & 1,86 & 2,11 & 0,59 & 1,33 & 0,73 & 0,94 \\
\hline 12 & 0,16 & 0,07 & 0,14 & 0,21 & 0,15 & 0,19 & 0,13 & 0,15 & 0,09 & 0,08 & 0,10 & 0,09 & 0,09 & 0,08 & 0,23 & 0,09 & 0,37 & 0,15 \\
\hline 13 & 1,07 & 15,96 & 3,43 & 1,45 & 3,40 & 1,44 & 6,77 & 2,27 & 3,10 & 4,04 & 4,54 & 3,71 & 2,17 & 1,65 & 1,36 & 2,97 & 2,31 & 2,26 \\
\hline 14 & 56,89 & 13,34 & 13,74 & 8,01 & 10,33 & 17,17 & 10,53 & 9,80 & 13,14 & 10,62 & 13,42 & 14,22 & 137,16 & 17,50 & 7,67 & 14,54 & 34,98 & 10,90 \\
\hline 15 & $55,04 \%$ & $54,88 \%$ & $67,13 \%$ & $21,65 \%$ & $41,35 \%$ & $49,70 \%$ & $17,39 \%$ & $27,95 \%$ & $15,49 \%$ & $20,28 \%$ & $12,03 \%$ & $33,99 \%$ & $27,77 \%$ & $21,55 \%$ & $27,51 \%$ & $34,97 \%$ & $14,71 \%$ & $17,88 \%$ \\
\hline 16 & $-21,19 \%$ & $-15,59 \%$ & $-33,00 \%$ & $-23,25 \%$ & $-21,84 \%$ & $-33,75 \%$ & $-30,90 \%$ & $-7,26 \%$ & $-24,11 \%$ & $-10,87 \%$ & $4,45 \%$ & $36,62 \%$ & $9,83 \%$ & $34,46 \%$ & $27,58 \%$ & $46,96 \%$ & $38,91 \%$ & $41,24 \%$ \\
\hline 17 & $0,71 \%$ & $2,11 \%$ & $1,51 \%$ & $2,63 \%$ & $2,89 \%$ & $2,44 \%$ & $1,52 \%$ & $2,83 \%$ & $3,29 \%$ & $2,65 \%$ & $2,96 \%$ & $2,19 \%$ & $4,23 \%$ & $3,53 \%$ & $5,43 \%$ & $1,90 \%$ & $5,10 \%$ & $2,00 \%$ \\
\hline 18 & $5,98 \%$ & $9,65 \%$ & $49,46 \%$ & $26,81 \%$ & $25,68 \%$ & $18,36 \%$ & $26,18 \%$ & $-33,31 \%$ & $-5,72 \%$ & $11,94 \%$ & $10,22 \%$ & $-1,46 \%$ & $-76,05 \%$ & $-11,15 \%$ & $23,78 \%$ & $15,06 \%$ & $31,91 \%$ & $5,09 \%$ \\
\hline
\end{tabular}




\section{P priedas. Optimalios portfeliu sudètys}

P.1 lentelè. Optimalios portfelių sudètys, \%

Table P.1. Optimal compositions of portfolios, \%

\begin{tabular}{|c|c|c|c|c|c|c|c|c|c|c|c|c|c|c|c|c|c|c|c|}
\hline \multirow{2}{*}{$\begin{array}{l}\text { Sprendimo } \\
\text { prièmimo } \\
\text { momentas }\end{array}$} & \multirow{2}{*}{ Portfelis } & \multicolumn{18}{|c|}{ Analizuojamos akcijos } \\
\hline & & $\mathbf{A A}$ & BA & CAT & CVX & DD & GE & IBM & INTC & JNJ & KO & MCD & МMM & MRK & PFE & $\mathbf{T}$ & UTX & $\mathrm{VZ}$ & XOM \\
\hline & & & & & & & & & & & & & & & & & & & \\
\hline \multirow{3}{*}{ 2006-04-01 } & $\mathrm{P}(\mathbf{8 0 / 2 0 )}$ & 0,00 & 0,00 & 1,98 & 19,33 & 0,00 & 0,00 & 0,00 & 0,70 & 20,05 & 0,00 & 33,16 & 1,87 & 10,13 & 0,00 & 12,76 & 0,00 & 0,00 & 0,00 \\
\hline & $P(60 / 40)$ & 0,00 & 0,00 & 0,00 & 25,11 & 0,00 & 0,00 & 0,00 & 0,74 & 15,03 & 0,00 & 25,95 & 3,04 & 15,29 & 0,00 & 14,46 & 0,00 & 0,38 & 0,00 \\
\hline & P(Markowitz) & 0,00 & 12,14 & 35,09 & 0,00 & 0,00 & 0,00 & 0,00 & 0,00 & 47,78 & 0,00 & 4,99 & 0,00 & 0,00 & 0,00 & 0,00 & 0,00 & 0,00 & 0,00 \\
\hline & & & & & & & & & & & & & & & & & & & \\
\hline \multirow{3}{*}{ 2007-04-01 } & $\mathrm{P}(\mathbf{8 0 / 2 0 )}$ & 6,60 & 0,00 & 0,00 & 3,31 & 0,00 & 15,36 & 0,00 & 0,00 & 9,59 & 0,00 & 0,00 & 15,04 & 0,00 & 25,34 & 24,48 & 0,00 & 0,27 & 0,00 \\
\hline & $P(60 / 40)$ & 5,26 & 0,00 & 0,00 & 10,44 & 0,00 & 13,52 & 0,00 & 0,00 & 9,86 & 0,00 & 0,00 & 15,14 & 0,00 & 28,90 & 7,67 & 0,00 & 9,21 & 0,00 \\
\hline & P(Markowitz) & 0,00 & 31,79 & 0,00 & 3,23 & 0,00 & 0,00 & 0,00 & 0,00 & 6,60 & 4,02 & 18,26 & 0,00 & 0,00 & 0,00 & 19,47 & 16,63 & 0,00 & 0,00 \\
\hline & & & & & & & & & & & & & & & & & & & \\
\hline \multirow{3}{*}{ 2008-04-01 } & $\mathrm{P}(80 / 20)$ & 0,00 & 9,61 & 0,00 & 3,97 & 16,53 & 0,00 & 0,00 & 0,00 & 0,00 & 14,51 & 0,00 & 5,43 & 3,41 & 12,78 & 33,77 & 0,00 & 0,00 & 0,00 \\
\hline & $P(60 / 40)$ & 0,00 & 0,00 & 0,00 & 14,43 & 5,29 & 6,44 & 3,31 & 5,80 & 5,49 & 7,55 & 0,00 & 6,84 & 2,73 & 16,19 & 13,46 & 4,40 & 4,34 & 3,73 \\
\hline & P(Markowitz) & 0,00 & 18,30 & 5,53 & 10,75 & 8,40 & 0,00 & 0,00 & 0,00 & 0,00 & 21,90 & 14,76 & 0,00 & 0,00 & 0,00 & 14,57 & 5,79 & 0,00 & 0,00 \\
\hline & & & & & & & & & & & & & & & & & & & \\
\hline \multirow{3}{*}{ 2009-04-01 } & $\mathrm{P}(80 / 20)$ & 0,00 & 0,00 & 0,00 & 24,47 & 0,00 & 28,90 & 9,23 & 0,00 & 0,00 & 0,00 & 0,00 & 8,56 & 13,52 & 10,20 & 5,12 & 0,00 & 0,00 & 0,00 \\
\hline & $P(60 / 40)$ & 0,00 & 0,00 & 0,00 & 29,15 & 0,00 & 0,00 & 4,87 & 4,59 & 0,00 & 0,00 & 0,00 & 18,10 & 0,24 & 33,47 & 0,00 & 0,00 & 9,57 & 0,00 \\
\hline & P(Markowitz) & 0,00 & 0,00 & 0,00 & 0,00 & 0,00 & 0,00 & 0,00 & 0,00 & 0,00 & 0,00 & 100,00 & 0,00 & 0,00 & 0,00 & 0,00 & 0,00 & 0,00 & 0,00 \\
\hline & & & & & & & & & & & & & & & & & & & \\
\hline \multirow{3}{*}{ 2010-04-01 } & $\mathrm{P}(80 / 20)$ & 0,00 & 0,00 & 0,00 & 0,00 & 0,00 & 0,00 & 22,40 & 0,00 & 0,00 & 13,57 & 13,55 & 0,00 & 0,00 & 0,00 & 0,00 & 0,00 & 50,01 & 0,47 \\
\hline & $P(60 / 40)$ & 0,00 & 0,00 & 0,00 & 0,00 & 0,00 & 0,00 & 21,53 & 0,00 & 0,00 & 10,91 & 18,17 & 0,00 & 0,00 & 0,00 & 0,00 & 0,00 & 49,38 & 0,00 \\
\hline & \begin{tabular}{|l|}
$\mathbf{P}($ Markowitz) \\
\end{tabular} & 0,00 & 0,00 & 28,02 & 0,00 & 0,00 & 0,00 & 0,00 & 0,00 & 0,00 & 0,00 & 71,98 & 0,00 & 0,00 & 0,00 & 0,00 & 0,00 & 0,00 & 0,00 \\
\hline & & & & & & & & & & & & & & & & & & & \\
\hline \multirow{3}{*}{ 2011-04-01 } & $P(80 / 20)$ & 0,00 & 0,00 & 0,00 & 12,57 & 0,00 & 0,00 & 9,40 & 10,41 & 0,00 & 0,00 & 18,49 & 0,00 & 0,00 & 0,00 & 0,00 & 0,00 & 47,07 & 2,05 \\
\hline & $\mathrm{P}(60 / 40)$ & 0,00 & 0,00 & 0,00 & 17,42 & 0,00 & 0,00 & 1,68 & 14,23 & 0,00 & 0,00 & 18,38 & 0,00 & 16,45 & 0,00 & 0,00 & 0,00 & 31,84 & 0,00 \\
\hline & P(Markowitz) & 0,00 & 0,00 & 32,17 & 0,00 & 0,00 & 0,00 & 0,00 & 0,00 & 0,00 & 0,00 & 67,83 & 0,00 & 0,00 & 0,00 & 0,00 & 0,00 & 0,00 & 0,00 \\
\hline
\end{tabular}


Grigorij ŽILINSKIJ

INVESTICIJŲ PORTFELIO SPRENDIMAI

Daktaro disertacija

Socialiniai mokslai,

ekonomika (04S)

INVESTMENT PORTFOLIO SOLUTIONS

Doctoral Dissertation

Social Sciences,

Economics (04S)

201212 07. 12,75 sp. I. Tiražas 20 egz.

Vilniaus Gedimino technikos universiteto

leidykla "Technika“,

Saulètekio al. 11, 10223 Vilnius,

http://leidykla.vgtu.lt

Spausdino UAB "Ciklonas"

J. Jasinskio g. 15, 01111 Vilnius 